GÖTTINGER ZENTRUM

FÜR BIODIVERSITÄTSFORSCHUNG UND ÖKOLOGIE

\title{
Trace gas fluxes and belowground carbon allocation in tropical montane forest soils of Southern Ecuador
}

\author{
Dissertation zur Erlangung des Doktorgrades der \\ Mathematisch-Naturwissenschaftlichen Fakultäten der \\ Georg-August-Universität Göttingen
}

vorgelegt von

Diplom Geographin

Katrin Wolf

aus

Dachau

Göttingen, Dezember 2010 
Referentin/Referent: $\quad$ Prof. Dr. Edzo Veldkamp

Korreferentin/Korreferent: Prof. Dr. Heiner Flessa

Tag der mündlichen Prüfung: $\quad$ 24.01.2011 


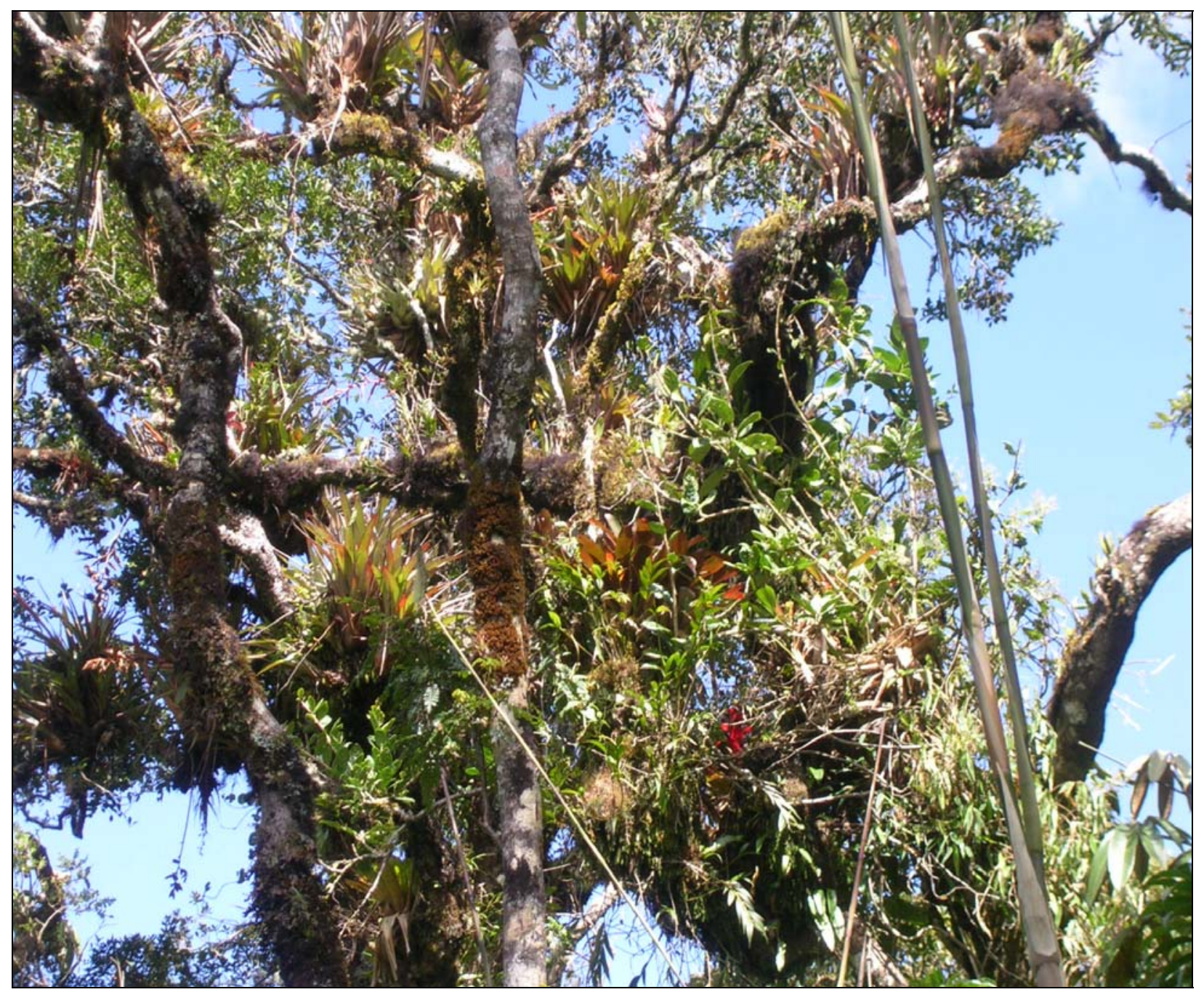

EL ERROR NUESRO ES PENSAR QUE LA NATURALEZA

ES DE NOSOTROS, CUNADO EN REALIDAD,

NOSOTROS SOMOS PARTE DE ELLA

Wrightihg at the Entrance to the Podocarpus National park in Bombuscaro 



\section{TABLE OF CONTENTS}

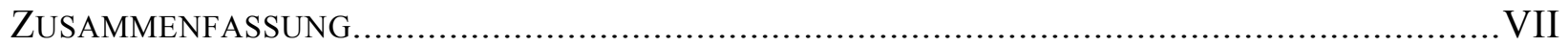

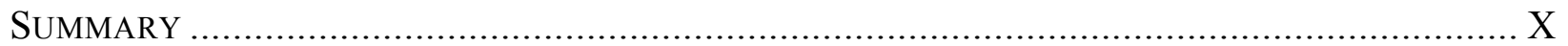

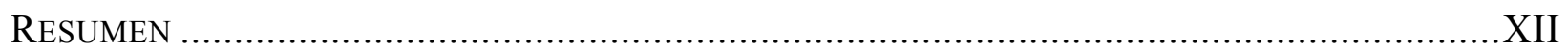

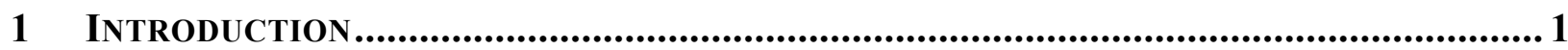

1.1 Distribution and physiognomy of tropical montane forests ............................... 3

1.2 Tropical montane forests ecosystem functioning ......................................... 4

1.3 Soil trace gas fluxes in tropical montane forests.......................................... 5

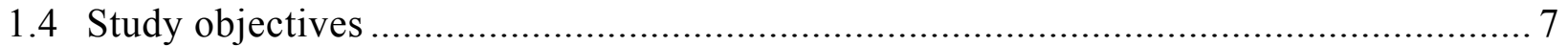

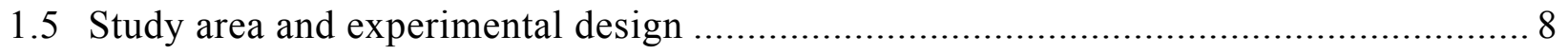

1.6 Methodological outline of soil trace gas flux measurements .............................. 10

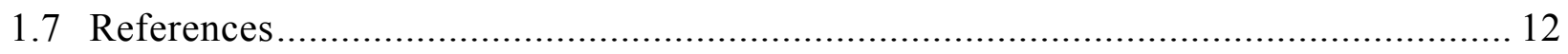

2 Nitrogen Availability Links forest Productivity, Soll Nitrous Oxide and Nitric OXide FluXes of a Tropical Montane Forest in Southern Ecuador. 17

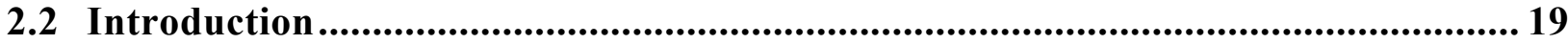

2.3 Material and Methods ........................................................................... 21

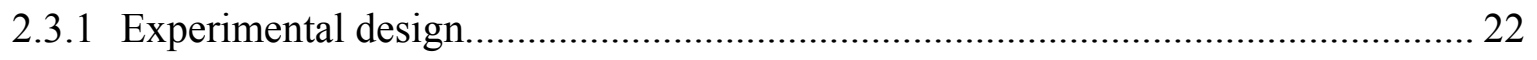

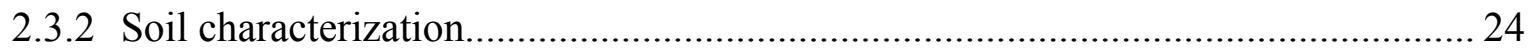

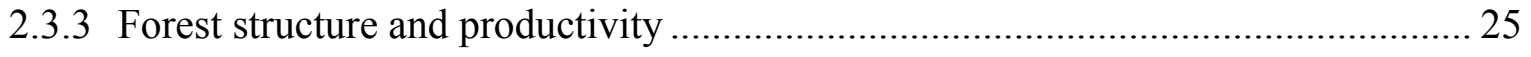

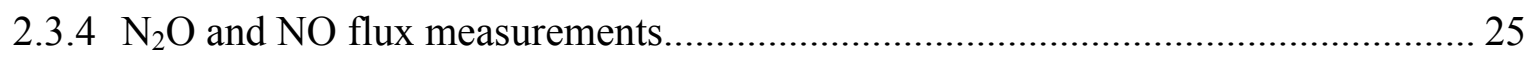

2.3.5 Soil mineral N, net N-mineralization and net nitrification ............................... 27

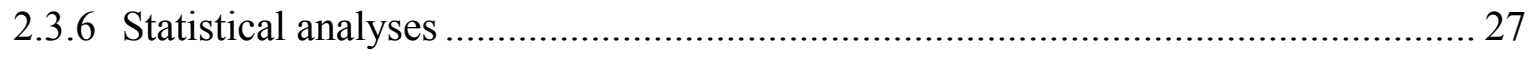

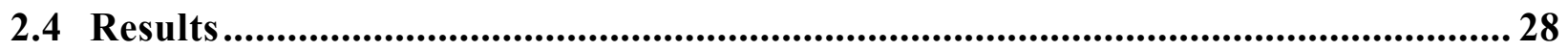

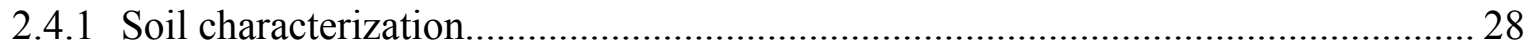

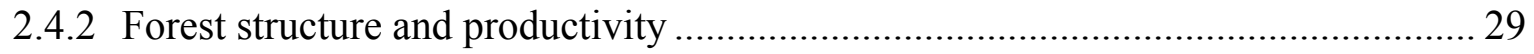

2.4.3 N-oxide fluxes and soil moisture ................................................................ 32

2.4.4 Indices of $\mathrm{N}$ availability and their control on $\mathrm{N}$-oxide fluxes............................ 34

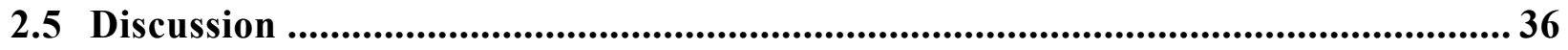


2.5.1 Organic layers and nitrogen availability along elevation and topographic gradients

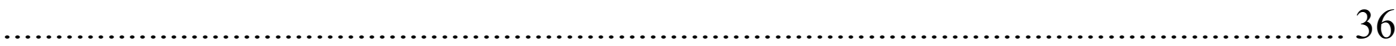

2.5.2 $\mathrm{N}$ availability and forest productivity ...................................................... 37

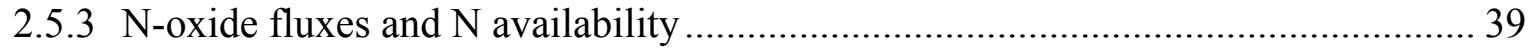

2.5.4 Nitrogen availability as a link between forest productivity and N-oxide fluxes .... 40

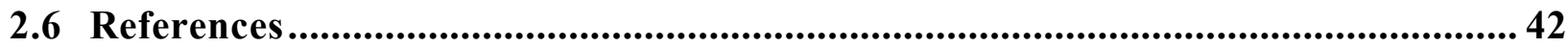

3 Atmospheric Methane Uptake by Tropical Montane Forest Soils and the CONTRIBUTION OF ORgANIC LAYERS ........................................................... 47

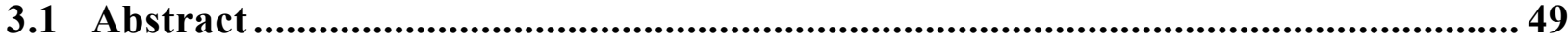

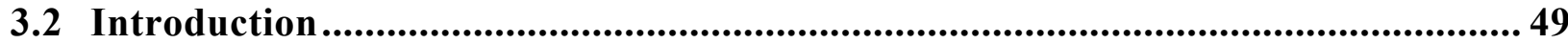

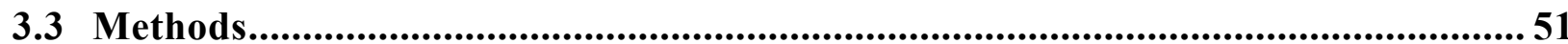

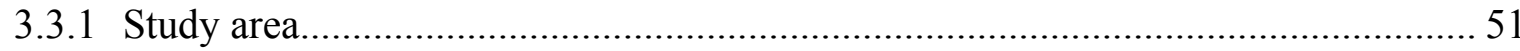

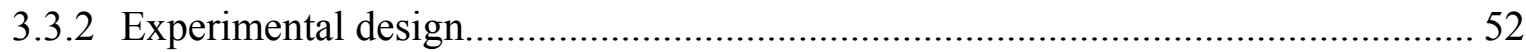

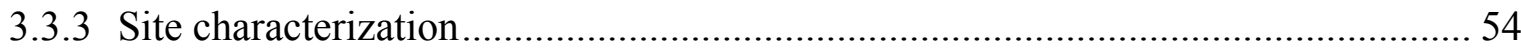

3.3.4 Field measurement of net $\mathrm{CH}_{4}$ exchange and soil respiration ............................. 55

3.3.5 $\mathrm{CH}_{4}$ concentration in soil air of organic layers .............................................. 56

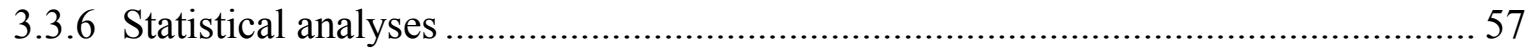

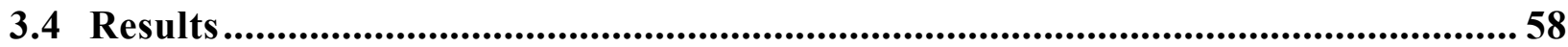

3.4.1 Soil net $\mathrm{CH}_{4}$ fluxes along elevation and topographic gradients .......................... 58

3.4.2 Potential uptake of atmospheric $\mathrm{CH}_{4}$ at different soil depths ............................. 63

3.4.3 $\mathrm{CH}_{4}$ concentrations in the soil air of organic layers ........................................ 66

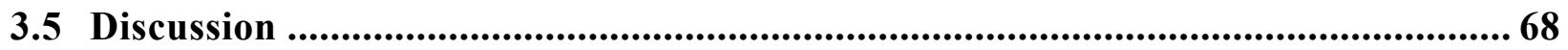

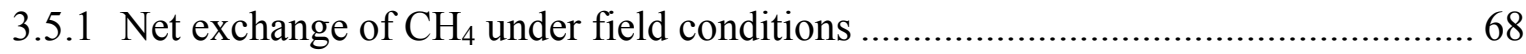

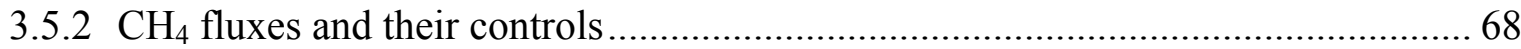

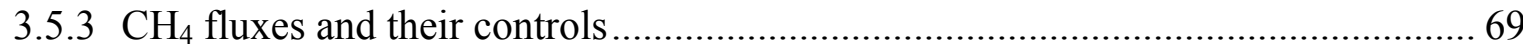

3.5.4 Stratification of potential uptake of atmospheric $\mathrm{CH}_{4}$ in mineral soil and organic

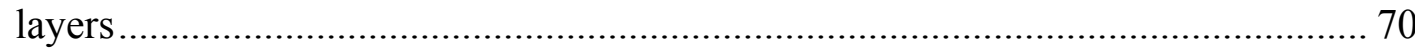

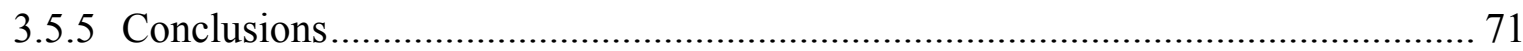

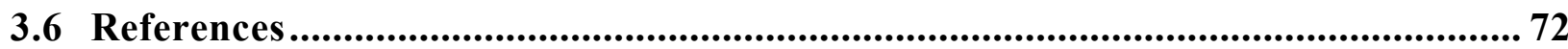

4 Soil nutrient Availability and Belowground Carbon allocation of TropicAl MONTANE ForestS IN SOUTHERN ECUAdOR ......................................... 77 


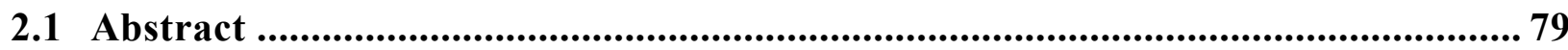

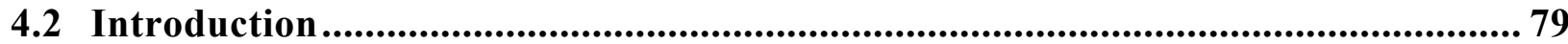

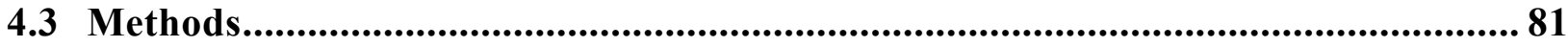

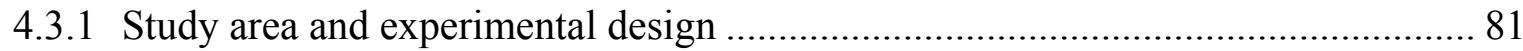

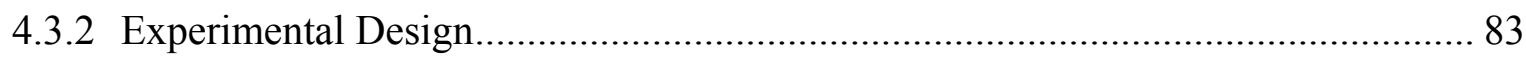

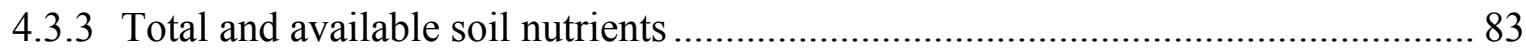

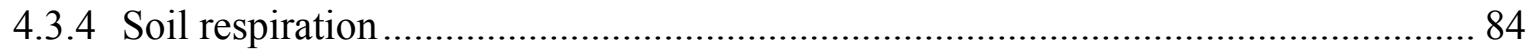

4.3.5 Aboveground productivity and litter quality................................................... 85

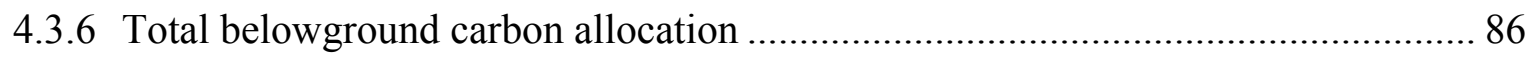

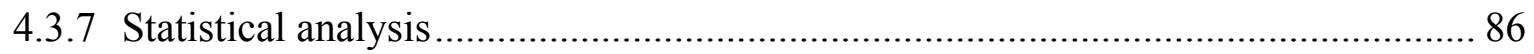

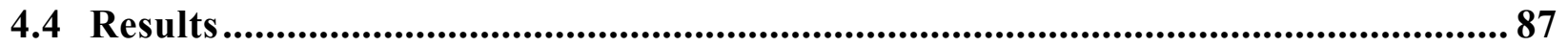

4.4.1 Soil total and available nutrients.................................................................... 87

4.4.2 Litter quality ................................................................................................... 90

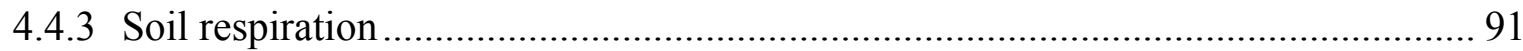

4.4.4 Aboveground productivity ............................................................................... 95

4.4.5 Total belowground carbon allocation ………………........................................ 97

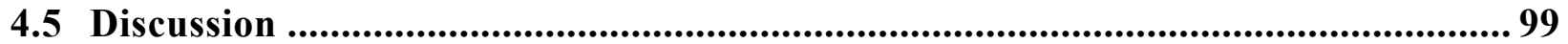

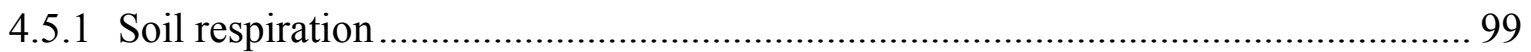

4.5.2 Soil nutrient availability and aboveground productivity ........................................ 99

4.5.3 Total belowground carbon allocation ……………………………………….... 100

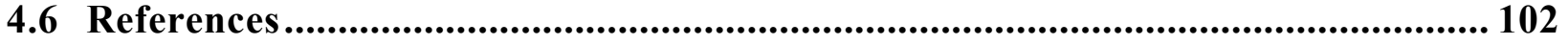

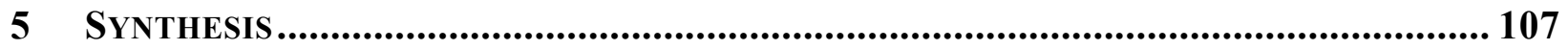

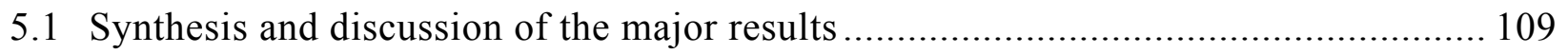

5.2 Implications for ecosystem response to environmental change ............................... 115

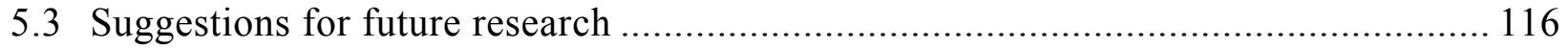

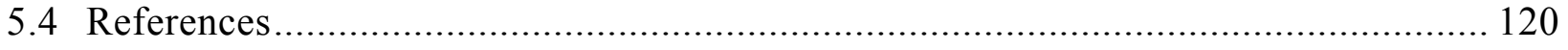

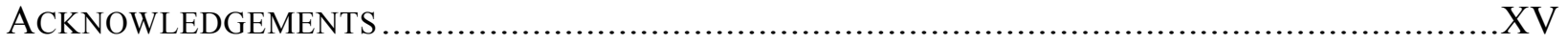

DECLARATION OF ORIGINALITY AND CERTIFICATE OF AUTHORSHIP ................................. XVI

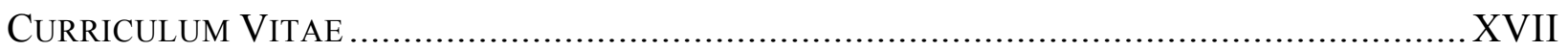




\section{LIST OF TABLES}

Table 2.1: Site characteristics of the topographic positions across the elevation gradient. 23

Table 2.2: Forest structure, productivity and total litterfall characteristics of the topographic positions across the elevation gradient. 30

Table 2.3: Annual N-oxide fluxes of the topographic positions across the elevation gradient.... 33

Table 2.4: Average soil mineral $\mathrm{N}$, net $\mathrm{N}$ mineralization and net nitrification rates of the topographic positions across the elevation gradient. 33

Table 3.1: Site characteristics and soil properties of the upper mineral soil (Ah-horizon) at the topographic positions across the elevation gradient 53

Table 3.2: Mean annual soil $\mathrm{CH}_{4}$ and $\mathrm{CO}_{2}$ fluxes and parallel measured parameters of the top soil $(0-5 \mathrm{~cm})$ at the topographic positions across the elevation gradient. 60

Table 3.3: Soil characteristics and annual flux rates of $\mathrm{CH}_{4}$ and $\mathrm{CO}_{2}$ of soils from two substrates of the topographic positions at $1000 \mathrm{~m}$. 61

Table 4.1: Site characteristics, forest structure and forest productivity of the topographic positions across the elevation gradient.

Table 4.2: Nutrient input, $\mathrm{C}$ :nutrient ratios in aboveground litterfall and $\mathrm{C}: \mathrm{N}$ ratios, available and total phosphorus $(\mathrm{P})$ and potassium $(\mathrm{K})$ stocks at different soil depths and of the topographic positions along the elevation gradient. 89

Table 4.3: Carbon fluxes of the topographic positions across the elevation gradient. 93

Table 4.4: Carbon fluxes, available and total nutrient stocks at different soil depths of two different geological substrates at the $1000 \mathrm{~m}$ site 93

Table 5. 1: Compilation of published soil trace gas emissions from old growth tropical montane forest soils 110 


\section{LIST OF FIGURES}

Figure 1.1: Location of the three study sites within and close to the National Park Podocarpus in southern Ecuador.. 8

Figure 1.2: Pictures of the forests at three landscape positions along the elevation gradient........ 9

Figure 1.3: Field and laboratory equipment for soil trace gas flux measurements..................... 10

Figure 2.1: Linear regression of litterfall $\mathrm{N}$ and indices of tree productivity ............................... 31

Figure 2.2: Linear regression of $\mathrm{C}: \mathrm{N}$ ratio of litterfall and indices of tree productivity............... 31

Figure 2.3: Linear regression of annual $\mathrm{N}_{2} \mathrm{O}+\mathrm{NO}$ fluxes and indices of $\mathrm{N}$ availability and of tree productivity

Figure 3.1: Annual course of soil net $\mathrm{CH}_{4}$ exchange rates and gravimetric soil moisture. 59

Figure 3.2: Relation between field measured and incubated soil $\mathrm{CO}_{2}$ emission rates and soil $\mathrm{CH}_{4}$ uptake rates 62

Figure 3.3: Mean $\mathrm{CH}_{4}$ uptake rates of undisturbed field moist-soil samples at different depths of the mineral soil profiles.

Figure 3.4: Mean $\mathrm{CH}_{4}$ fluxes of undisturbed, field-moist soil samples from different depths of the organic layer and the underlying mineral soil

Figure 3.5: Temperature relation of $\mathrm{CO}_{2}$ and $\mathrm{CH}_{4}$ fluxes of undisturbed, field-moist samples of the mean organic layer profile 66

Figure 3.6: Mean soil air $\mathrm{CH}_{4}$ concentrations at different depths of the organic layer during a wet period and a dry period

Figure 4.1: Relationship between litterfall nutrient concentration and total and available nutrient stocks of the organic layer 91

Figure 4.2: Relationship between soil respiration indices of nutrient availability 92

Figure 4.3: Relationship between aboveground litterfall and total an $d$ available nutrient stocks in the organic layer and the mineral soil

Figure 4.4: Relationship between soil respiration and TBCA and gravimetric soil moisture content and organic layer thickness. 98 



\section{ZUSAMMENFASSUNG}

Tropische Wälder sind eine wichtige Quelle für die Treibhausgase Kohlendioxid $\left(\mathrm{CO}_{2}\right)$ und Distickstoffoxid (Lachgas, $\mathrm{N}_{2} \mathrm{O}$ ) und für Stickstoffmonoxid (NO), ein Ausgangsstoff bei der Bildung von Ozon, und sie sind Senken für das Treibhausgas Methan $\left(\mathrm{CH}_{4}\right)$. Die Einschätzung der Bodenspurengasflüsse und des Kohlenstoffkreislaufes tropischer Wälder ist derzeit noch überproportional stark von Arbeiten aus Tieflandwäldern bestimmt. In Bezug auf den Spurengasaustausch in tropischen Bergwäldern (TMF), steht dagegen nur eine beschränkte Menge an Daten zur Verfügung und ihr Kohlenstoffkreislauf ist nur ansatzweise erforscht, obwohl TMFs etwa 9\% der tropischen Waldfläche ausmachen. In dieser Dissertation werden die Ergebnisse einer extensiven Studie über den Austausch von $\mathrm{CO}_{2}, \mathrm{~N}_{2} \mathrm{O}, \mathrm{NO}$, and $\mathrm{CH}_{4}$ zwischen Boden und Atmosphäre, dessen mögliche biogeochemische Einflussgrößen, sowie über die unterirdische Kohlenstoff-Allokation (TBCA) in tropischen Bergwäldern in Südecuador präsentiert. Der spezielle Fokus dieser Studie lag dabei auf dem Einfluss von Nährstofflimitierungen. Die Flüsse von $\mathrm{CO}_{2}, \mathrm{~N}_{2} \mathrm{O}$ and $\mathrm{CH}_{4}$ wurden mittels stationären geschlossenen Kammern und Gaschromatographie in drei Höhestufen entlang eines Höhengradienten von $1000 \mathrm{~m}$ bis $3000 \mathrm{~m}$ (1000 m, $2000 \mathrm{~m}, 3000 \mathrm{~m})$ und entlang topographischer Gradienten (Unterhang, Mittelhang, Kamm) bestimmt. NO Flüsse wurden im Feld unter Verwendung offener dymamischer Kammern und eines LMA-3D NO 2 Analysegeräts mit Chemilumineszenzdetektion gemessen. Zusätzlich wurde die potentielle Kapazität verschiedener Bodensubstrate aus mehreren Bodentiefen $\mathrm{CH}_{4}$ in atmosphärischen Konzentrationen aufzunehmen mittels eines Labor-Inkubationsversuchs untersucht. Die Bestimmung der Nährstoffverfügbarkeit im Boden erfolgte mit Hilfe verschiedener Extraktionmethoden und über die Interpretation diverser Indizes (C:N, C:K, C:P Verhältnisse, $\delta{ }^{15} \mathrm{~N}$ Signaturen der Streu). Zur Abschätzung der unterirdischen Kohlenstoff-Allokation schließlich, wurden einjährige Messungen von Bodenatmung und oberirdischer Streuproduktion herangezogen.

In den untersuchten TMFs nahm die Mächtigkeit der organischen Auflage mit steigender Meereshöhe und vom Unterhang zum Kamm zu, während die Nährstoffverfügbarkeit in gleicher Richtung abnahm. Die oberirdische Streuproduktion erwies sich als stickstoff- (N), phosphor- 
(P) und auf den meisten Flächen auch kalium- (K) limitiert. Sie war hauptsächlich and den Vorrat verfügbarer Nährstoffe in der organischen Auflage gebunden, obwohl der Mineralboden reicher an verfügbarem $\mathrm{P}$ und $\mathrm{K}$ war. Basalflächenzuwachs und oberidische Streuproduktion korrelierten positiv mit Indizes von Nährstoffverfügbarkeit $\left(\mathrm{C}: \mathrm{N}\right.$ Verhältnis und $\delta{ }^{15} \mathrm{~N}$ Signaturen der Streu), während die TBCA keine derartigen Zusammenhänge erkennen ließ. Die Abnahme der TBCA mit zunehmender Meereshöhe und vom Unterhang zu dem Kammlagen und stand vielmehr im Zusammenhang mit dem Bodenwassergehalt und der Mächtigkeit der organischen Auflage. Die Spurengasflüsse in den Böden unserer TMF Standorte waren niedriger, als die Flüsse vieler Tieflandstandorte und lagen im Allgemeinen innerhalb der bisher von tropischen Bergwäldern berichteten Spannweite. Stickoxid- und $\mathrm{CH}_{4}-$ Flüsse standen in keinem nachweisbaren Zusammenhang mit der Bodenfeuchte oder der Mächtigkeit der organischen Auflage, während die Bodenatmung mit beiden Parametern negativ korreliert war. Die Stickoxidflüsse waren positiv korreliert mit Indikatoren die die längerfristige N-verfügbarkeit widerspiegeln, wie C:N Verhältnis und $\delta{ }^{15} \mathrm{~N}$ Signaturen in der Streu, und mit Indikatoren der Waldprimärproduktivität, wie oberirdische Streuproduktion und Basalflächenzuwachs. Die Streuqualität hatte positiven Einfluss auf die Bodenatmung, und die Aufnahmeraten von $\mathrm{CH}_{4} \mathrm{im}$ Boden stiegen mit dem Gehalt an mineralischem N im Boden und dem Gesamtvorrat an P im Mineralboden, sowie mit zunehmenden $\mathrm{CO}_{2}$ Emission. Die Ergebnise des Inkubationsversuchs zeigten eine hohe potentielle $\mathrm{CH}_{4}$ Aufnahmekapazität in den unteren Schichten der organischen Auflagen der $2000 \mathrm{~m}$ und $3000 \mathrm{~m}$ Standorte.

Die engen Korrelationen von Nährstoffverfügbarkeit mit oberirdischer Streuproduktion und Basalflächenzuwachs können als Anzeichen einer Nährstofflimitierung der Waldprimärproduktion in den untersuchten TMFs interpretiert werden. Die dichte Durchwurzelung der organischen Auflagen und die engen Zusammenhänge zwischen der Nährstoffverfügbarkeit in der organischen Auflage und den Nährstoffkonzentationen in der Streu deuten darauf hin, dass der Nährstoffkreislauf in den organischen Auflagen konzentriert und weitgehend vom Mineralboden entkoppelt ist. Im Gegensatz zur oberirdischen Waldprimärproduktivität war die TBCA nicht nährstofflimitiert. Die Abnahme der TBCA mit ansteigender Meereshöhe ging mit einer Zunahme der Feinwurzelbiomasse einher, was durch längere Persistenz der Wurzeln erklärt werden kann. Zusammen mit einem langsamen Abbau der 
organischen Substanz, mag dies zur hohen C-Speicherung in den organischen Auflagen der TMFs beitragen.

Spurengasflüsse waren positiv mit verschiedenen Indizes von Nährstoffverfügbarkeit korreliert. Wir fanden Anzeichen dafür, dass zunehmend ungünstige Bodenbedingungen und schlechtere Streuqualität die allgemeine mikrobielle Aktivität mindern und somit Bodenatmung, Stickoxidflüsse und die Aufnahme von $\mathrm{CH}_{4}$ verringern. Enge lineare Zusammenhänge von Noxiden mit oberirdischer Streuproduktion und Basalflächenzuwachs zeigen, dass Stickoxidflüsse und Waldprimärproduktivität über die N-verfügbarkeit verbunden sind und eröffnen die Möglichkeit, die Waldprimärproduktivität (speziell den Basalflächenzuwachs) als Kovariable in Vorhersagemodelle für Stickoxidflüsse in N-limitierten Ökosystemen zu integrieren. $\mathrm{CH}_{4}$ Aufnahmeraten waren positiv mit Konzentrationen von mineralischem Stickstoff im Boden korreliert, was darauf hinweist, dass $\mathrm{CH}_{4}$ Aufnahmen in erster Linie nährstofflimitiert waren und der Mechanismus der Ammoniuminhibition als regulierender Faktor vernachlässigbar ist. Im Gegensatz zur weitverbreiteten Annahme, stellten die organischen Auflagen in den untersuchten TMFs keine reinen Gasdiffusionsbarrieren dar, sondern zeigten beträchtliche, potentielle $\mathrm{CH}_{4}$ Aufzunahmekapazitäten und könnten damit zur Entfernung von $\mathrm{CH}_{4}$ aus der Atmosphäre beitragen. 


\section{SUMMARY}

Tropical forest soils are important sources of the greenhouse gases carbon dioxide $\left(\mathrm{CO}_{2}\right)$ and nitrous oxide $\left(\mathrm{N}_{2} \mathrm{O}\right)$, and of nitric oxide $(\mathrm{NO})$, a precursor of ozone production. They are also sinks for the greenhouse gas methane $\left(\mathrm{CH}_{4}\right)$. Estimates on soil trace gas fluxes and on carbon cycling from tropical forest soils are heavily biased towards lowland forests. Limited data is available on trace gas exchange from tropical montane forest (TMF) soils and their carbon cycle has only been marginally explored, although TMFs cover approximately $9 \%$ of the tropical forest area. This dissertation presents the results of a comprehensive study on soil $\mathrm{CO}_{2}, \mathrm{~N}_{2} \mathrm{O}, \mathrm{NO}$, and $\mathrm{CH}_{4}$ exchange and possible biogeochemical regulators, with a special focus on the influence of nutrient availability in TMFs of southern Ecuador. Soil $\mathrm{CO}_{2}, \mathrm{~N}_{2} \mathrm{O}$ and $\mathrm{CH}_{4}$ fluxes were determined using static closed chambers and gas chromatographic analysis at three sites along an elevation gradient from $1000 \mathrm{~m}$ to $3000 \mathrm{~m}(1000 \mathrm{~m}, 2000 \mathrm{~m}, 3000 \mathrm{~m})$ and along topographic gradients (lower slope, midslope, ridge), NO fluxes were measured in the field using open dynamic chambers and a LMA-3D $\mathrm{NO}_{2}$ Analyzer with chemiluminescence detection. To determine the potential atmospheric $\mathrm{CH}_{4}$ uptake of different soil substrates, a laboratory incubation experiment using organic layer and mineral soil samples from different soil depths was conducted. Nutrient availability was determined by applying various extraction methods and by evaluating several indices (C:N, C:K, C:P ratios, $\delta{ }^{15} \mathrm{~N}$ signature of litterfall). Finally, total belowground carbon allocation (TBCA) was estimated from year-round soil respiration and aboveground litterfall measurements.

Soil organic layer thickness increased while nutrient availability decreased with both increasing elevation and along the topographic gradient from the lower slope to the ridges. Aboveground litter production appeared to be limited by nitrogen $(\mathrm{N})$, phosphorus $(\mathrm{P})$ and to a certain degree by potassium $(\mathrm{K})$. It was positively related mainly to available nutrient stocks of the organic layer, although stocks of $\mathrm{K}$ and $\mathrm{P}$ were larger in the mineral soil. Tree basal area increment and aboveground litter production showed close positive correlations with indices of $\mathrm{N}$ availability (C:N ratio and $\delta{ }^{15} \mathrm{~N}$ signature of litterfall), while TBCA was not correlated to nutrient availability. TBCA decreased with elevation and from the lower slope position toward the ridges and was negatively correlated to soil moisture and organic layer thickness. Soil trace 
gas fluxes from the three TMF sites were lower than reported for tropical lowland sites but were generally within the range reported in other montane forest sites. Soil respiration was positively correlated with both parameters, whereas no correlations of $\mathrm{N}$-oxides and $\mathrm{CH}_{4}$ with soil moisture and organic layer thickness were found. N-oxide fluxes showed close positive correlations with long-term indices of $\mathrm{N}$ availability (e.g. C:N ratio, the $\delta^{15} \mathrm{~N}$ signature of litterfall) and with indices of forest productivity, such as aboveground litter production and tree basal area increment. Soil respiration was positively correlated with litter quality indices. $\mathrm{CH}_{4}$ uptake rates increased with soil mineral $\mathrm{N}$ content, total $\mathrm{P}$ content of the mineral soil and with increasing $\mathrm{CO}_{2}$ emissions. Incubated samples from the deepest organic layers at the $2000 \mathrm{~m}$ and $3000 \mathrm{~m}$ sites revealed high potential $\mathrm{CH}_{4}$ oxidation rates.

The close correlations of nutrient availability with aboveground litterfall and tree basal area increment is an evidence that forest productivity is nutrient limited in the investigated TMFs. Dense rooting of the organic layer and the close relationships between nutrient availability in the organic layer and nutrient concentrations in aboveground litterfall, suggest that nutrient cycling is concentrated in the organic layer and is largely decoupled from the mineral soil. In contrast to aboveground forest productivity, TBCA was not related to nutrient availability. The decline in TBCA with increasing elevation at our study site corresponded with an increase in fine root biomass which can be explained with higher root longevity. Together with slow decomposition rates in the organic layers, this may contribute to the large carbon storage in organic layers of TMF soils. Soil trace gas fluxes were correlated positively with different indices of nutrient availability. We found evidence that increasingly adverse soil conditions (low nutrient availability, high soil moisture) and lower litter quality limit microbial activity and consequently reduce soil respiration, $\mathrm{N}$-oxide fluxes and $\mathrm{CH}_{4}$ uptake capacity of the soils. The close linear correlations of $\mathrm{N}$-availability with forest productivity and $\mathrm{N}$-oxide fluxes show that $\mathrm{N}$ availability links N-oxide fluxes and forest productivity and opens the possibility to include forest productivity, especially tree basal area increment, as co-variable to predict N-oxide fluxes in nitrogen limited TMFs. The largest $\mathrm{CH}_{4}$ uptake corresponded with high concentrations of soil mineral $\mathrm{N}$ indicating that atmospheric $\mathrm{CH}_{4}$ uptake primarily nutrient-limited, and that ammonia inhibition may be neglected as regulating factor for soil $\mathrm{CH}_{4}$ oxidation in these soils. Contrary to findings in temperate forests the organic layer did not only act as gas diffusion barriers, but showed substantial potential to oxidize atmospheric $\mathrm{CH}_{4}$. 


\section{RESUMEN}

Los bosques tropicales son fuentes importantes de gases de efecto invernadero como el dióxido de carbono $\left(\mathrm{CO}_{2}\right)$, óxido de nitrógeno $\left(\mathrm{N}_{2} \mathrm{O}\right)$ y de monóxido de nitrógeno $(\mathrm{NO})$; el cual es un precursor de la producción de ozono y además son sumideros de los gases de efecto invernadero como el metano $\left(\mathrm{CH}_{4}\right)$. Estimaciones de los flujos de gases traza y el ciclo del carbono de los suelos de los bosques tropicales están fuertemente sesgados hacia los bosques de tierras bajas. Hay escasos datos disponibles sobre el intercambio de gases de los bosques tropicales de montaña (tropical montane forest, TMF) y su ciclo del carbono ha sido explorado marginalmente, a pesar de que los TMF cubren cerca el 9\% del área de los bosques tropicales. Esta tesis presenta los resultados de un extensivo estudio sobre el intercambio de $\mathrm{CO}_{2}, \mathrm{NO}_{2}, \mathrm{NO}$ y $\mathrm{CH}_{4}$ en el suelo y sus posibles reguladores biogeoquímicos con un especial enfoque en la influencia de la disponibilidad de nutrientes en los TMF en el sur del Ecuador

En tres sitios a lo largo de la gradiente de elevación comprendida entre los 1000 hasta los 3000 ms.n.m. (1000, 2000, 3000 ms.n.m.) y a lo largo también de gradientes topográficas (baja pendiente, pendiente media y crestas de montaña), flujos de $\mathrm{CO}_{2}, \mathrm{~N}_{2} \mathrm{O}$ y $\mathrm{CH}_{4}$ en el suelo fueron determinados usando cámaras estáticas cerradas y análisis por cromatografía de gases. Los flujos de $\mathrm{NO}$ fueron medidos en el campo usando cámaras dinámicas abiertas y LMA-3D $\mathrm{NO}_{2}$ analizador con detección de quimioluminiscencia. Para determinar el potencial de absorción de $\mathrm{CH}_{4}$ atmosférico en diferentes sustratos de suelo, un experimento de incubación de laboratorio con muestras de capas orgánicas y del suelo mineral provenientes de diferentes profundidades de suelo fue llevado a cabo. La disponibilidad de nutrientes en el suelo fue determinada aplicando varios métodos de extracción y por la elevación de varios índices $(C: N, C: K, C: P$ ratio, valor de $\delta{ }^{15} \mathrm{~N}$ de la hojarasca). Por último la asignación de carbono subterráneo (total belowground carbon allocation, TBCA) fue estimada a partir de las mediciones de la respiración del suelo y de la hojarasca superficial durante el un año.

El espesor de la capa orgánica del suelo aumentó y la disponibilidad de nutrientes disminuyó con el aumento de la altitud y desde la posición de las bajas pendientes a las crestas en el evaluado TMF. La producción de hojarasca superficial parecía estar limitada por Nitrógeno (N), Fósforo (P) y hasta cierto punto por el Potasio (K). Se relacionó positivamente sobre todo a las 
existencias disponibles de nutrientes de la capa orgánica, aunque las reservas de $\mathrm{K}$ y $\mathrm{P}$ fueron mayores en el suelo mineral. El incremento de la área basal de los arboles y la producción de hojarasca superficial mostraron estrechas correlaciones positivas con los índices de disponibilidad de $\mathrm{N}$ (C:N ratio y valor de $\delta{ }^{15} \mathrm{~N}$ de la hojarasca), mientras que TBCA no se correlacionó a la disponibilidad de nutrientes. TBCA disminuyó con la altitud y desde las pendientes bajas hacia las crestas y fue más bien relacionada con la humedad del suelo y el espesor de la capa orgánica. Los flujos de gases traza de los TMF fueron menores que los reportados para los sitios de tierras bajas tropicales y en general estuvieron entre los rangos reportados para otros sitios de bosques de montaña. No he encontrado correlaciones de óxidos-N y $\mathrm{CH}_{4}$ con la humedad del suelo y el espesor de la capa orgánica, mientras que la respiración del suelo se correlacionó positivamente con ambos parámetros. Los flujos óxidos- $\mathrm{N}$ mostraron estrechas correlaciones positivas con los índices de largo plazo de disponibilidad de N como C:N ratio y el valor de $\delta{ }^{15} \mathrm{~N}$ de la hojarasca y con los índices de productividad de los bosques, como producción de hojarasca superficial y el incremento de área basal de los árboles. La respiración del suelo se correlacionó positivamente con índices de calidad de hojarasca superficial y los valores de absorción de $\mathrm{CH}_{4}$ incrementaron con el contenido de Nitrógeno en el suelo, el contenido total de $\mathrm{P}$ del suelo mineral y el incremento de las emisiones de $\mathrm{CO}_{2}$. Muestras incubadas de las partes más inferiores de las capas orgánicas de los sitios de los 2000 y 3000 ms.n.m. revelaron un alto potencial de absorción de $\mathrm{CH}_{4}$.

Las estrechas correlaciones de la disponibilidad de nutrientes con la hojarasca superficial y el incremento del área basal de los árboles pueden ser interpretadas como una evidencia de que la productividad de los bosques es limitada en nutrientes en el investigado TMF. El denso enraizamiento de la capa orgánica y la inmediata relación entre la disponibilidad de nutrientes en la capa orgánica y la concentración de nutrientes en la hojarasca superficial sugieren que el ciclo de los nutrientes esta concentrado en la capa orgánica y en gran parte disociada del suelo mineral. En contraste a la productividad de la superficie forestal, TBCA no estaba relacionado con la disponibilidad de nutrientes. La disminución de TBCA con el incremento de la elevación en nuestro estudio correspondió con un incremento en la biomasa de raíces finas lo cual puede ser explicado con la más alta longevidad de las raíces. Junto con el lento proceso de descomposición cuantificado, en las capas orgánicas, esto puede contribuir a la retención de carbono en grandes capas orgánicas de los suelos del TMF. El flujo de gases traza en el suelo fue 
correlacionado positivamente con diferentes índices de disponibilidad de nutrientes. Se han encontrado evidencias de que las condiciones del suelo cada vez más adversas y la menor calidad de la hojarasca, por lo general limitan la actividad microbiana y así reduce la respiración del suelo, los flujos de óxidos-N y la capacidad de absorción de $\mathrm{CH}_{4}$ de los suelos. Las correlaciones lineales estrechas de los flujos de óxido de $\mathrm{N}$ mostraron que la disponibilidad de $\mathrm{N}$ vincula flujos de óxidos-N y la productividad de los bosques y abrieron así la posibilidad de incluir la productividad forestal, especialmente el incremento en el área basal de los arboles como una covariable en las predicciones de flujos de óxidos-N en los TMF limitado de nitrógeno. La mayor absorción de $\mathrm{CH}_{4}$ correspondió con mayores concentraciones de $\mathrm{N}$ en el suelo mineral que indica que la absorción de $\mathrm{CH}_{4}$ atmosférico es principalmente limitada en nutrientes y que la inhibición amoniaco puede dejarse de lado como un factor regulador para la oxidación de $\mathrm{CH}_{4}$ del suelo, en estos suelos de bosques tropicales de Montana. Contrariamente a la creencia común, las caspas orgánicas no solo actuaron como barreras de difusión de gases, pero mostraron considerable capacidad potencial de oxidación para $\mathrm{CH}_{4}$ atmosférico y por lo tanto pueden contribuir a remover el $\mathrm{CH}_{4}$ de la atmósfera. 


\section{THESIS OUTLINE}

Chapter 1 gives an introduction to tropical montane forest (TMF) physiognomy and ecosystem functioning and presents a short overview over the current knowledge about trace gas fluxes from tropical forest soils. Furthermore, the objectives and hypotheses of this work are presented. At last, Chapter 1 provides general information about the study area in southern Ecuador and the methodology used for investigation. Chapter 2 addresses the question whether forest productivity and soil nitrous- and nitric-oxide fluxes are linked through soil nitrogen availability along elevation and topographic gradients in the studied ecosystem and assays the possibility to use forest productivity as a proxy for $\mathrm{N}$-oxide estimation. Chapter $\mathbf{3}$ investigates soil methane fluxes, their biogeochemical controls and the contribution of the organic layers to atmospheric methane uptake of TMF soils. Chapter 4 examines the influence of nutrient availability on total belowground carbon allocation along elevation and topographic gradients in TMFs. Chapter 5 summarizes and discusses the results presented in Chapters 2 to 4 and provides suggestions for further research.

This study was conducted within the framework of the DFG Research Unit 'Biodiversity and Sustainable Management of a Megadiverse Mountain Ecosystem in South Ecuador' (FOR 816) (http://www.tropicalmountainforest.org/). 



\section{CHAPTER}

INTRODUCTION 



\subsection{Distribution and physiognomy of tropical montane forests}

According to the definition of the Global Forest Resources Assessment 2000 (FAO 2000), tropical montane forests (TMF) are classified as forests within the tropical latitude which grow above $1000 \mathrm{~m}$ a.s.1. (FAO 2000). TMFs are distinguished from lowland forests mainly by their different physiognomy and flora. The transition zone from lowland to montane forests and altitudinal zonation within TMFs is compressed on small outlying mountains compared to large mountains ('Massenerhebung' effect, Richards 1952). Therefore, forests showing typical characteristics of TMFs may occur at elevations as low as $300 \mathrm{~m}$ in smaller mountain systems (Bubb et al. 2004). The altitudinal expansion of TMFs reaches to up to $4000 \mathrm{~m}$ on the Himalayan slopes of Asia and up to about $3500 \mathrm{~m}$ in Ethiopian highlands and the mountains of east Africa. In Central America TMFs grow up to altitudes of $3800 \mathrm{~m}$ (FAO 2000) and forests of the South American Andes reach altitudes of up to $4000 \mathrm{~m}$ (Richter 2008). Information on the land area covered by TMFs vary between 1.5 and $3.3 \cdot 10^{6} \mathrm{~km}^{2}$, which makes up between 9 and $22 \%$ of the world's tropical forest area (Bubb et al. 2004; FAO 2000). Ascending moist tropical mountain slopes, ecofloristic zones are successively shifting from lowland rainforest over premontane forest, lower montane forest (LMF) and upper montane forest (UMF) to elfin forests (Grubb et al. 1963). Besides the shift in plant species composition, the most remarkable feature of TMFs is the gradual decrease in tree height from up to $40 \mathrm{~m}$ in American lowland forests and 50 - $60 \mathrm{~m}$ in Asian lowland forests to less than $10 \mathrm{~m}$ in elfin forests (Aiba \& Kitayama 1999; Grubb 1977; Homeier et al. 2008; Leuschner \& Moser 2008; Raich 1998). Additional typical traits include more inclined tree trunks, a tendency to smaller, thicker and harder (xeromorphic) leaves and a higher abundance of epiphytes (Ashton 2003; Bruijnzeel \& Veneklaas 1998; Gradstein 2008; Grubb 1977). Similar changes in forest and leaf structure have also been found from lower slopes toward ridge positions in tropical mountains in Jamaica, Malaysia, American Samoa and Ecuador among others (Homeier et al. 2010; Takyu et al. 2002; Tanner 1977; Webb et al. 1999). To explain these differences, a variety of hypotheses has been proposed, most of which are related directly or indirectly to climate. Most prominently, lower temperatures, higher precipitation, increased cloud formation and fog occurrence as well as higher UV-B radiation and nutrient limitations have been suggested (Bruijnzeel \& Veneklaas 1998; Foster 2001; Gerold 2008; Grubb 1977; Tanner et al. 1998). 


\subsection{Tropical montane forests ecosystem functioning}

TMFs do not only differ from lowland forests in structure and flora, but also in ecosystem functioning (Bruijnzeel \& Veneklaas 1998). Regarding the present study the most important ecosystem functions are forest productivity, nutrient and carbon cycling and the mitigation of trace gas fluxes. TMFs generally exhibit smaller aboveground productivity compared to tropical lowland forests, as expressed by lower litterfall rates, a decline in aboveground tree biomass and stem girth in crement and slower ecosystem nutrient-cycling (Bruijnzeel \& Veneklaas 1998). Productivity of TMFs was shown to be limited by phosphorus $(\mathrm{P})$, potassium $(\mathrm{K})$ and, in contrast to many lowland forests, by nitrogen (N) (Tanner 1985; Tanner et al. 1998; Vitousek 1984). These findings appear to be mainly related to soil development (Walker \& Syers 1976). Soils under tropical lowland forests are often highly weathered (McGroddy et al. 2008), whereas erosion on the slopes of tropical mountains often leads to shallow and younger soils (Foster 2001). Phosphorus and $\mathrm{K}$ are macronutrients in the soil organic matter, which are almost exclusively supplied by the soils parent material (Walker \& Syers 1976). In contrast, carbon (C) and $\mathrm{N}$ are derived from the atmosphere and accumulate in the organic matter over time. Thus, with proceeding soil and ecosystem development, soils will become poorer in $\mathrm{P}$ and $\mathrm{K}$, which are successively bound in unavailable forms or washed out, and will become richer in $\mathrm{N}$ (Hedin et al. 2009). Additional to soil development other factors may contribute to observed nutrient limitations of TMF productivity. Increasingly adverse climatic conditions (low temperatures and high soil moisture content) and lower litter quality with increasing elevation reduce microbial mineralization of organic matter (Marrs et al. 1988; Tanner 1981; Vitousek \& Sanford 1986), causing nutrient accumulation in the thick organic layers that cover the mineral soil. Slower nutrient cycling and nutrient storage in organic matter are linked to efficient ecosystem nutrient use regarding N, P and K (Hedin et al. 2009; Vitousek 1984). TMFs reveal high nutrient use efficiencies in the sense that plants need less nutrients for a certain amount of $\mathrm{C}$ fixed, as indicated by high C:nutrient ratios in litterfall (Hedin et al. 2009; Vitousek 1984) and in terms of small nutrient leaching and gas losses.

Other important forest ecosystem functions are $\mathrm{C}$ sequestration and $\mathrm{C}$ storage. Global soil and vegetation $\mathrm{C}$ stocks in tropical forests account for about $1.1 * 10^{12} \mathrm{Mg} \mathrm{C}$ (Fischlin et al. 2007) which is equivalent to $148 \%$ of the atmospheric carbon. With respect to C fluxes, TMFs are 
among the least studied terrestrial ecosystems (Bruijnzeel \& Veneklaas 1998; Clark 2007). Reduced microbial mineralization rates and slower $\mathrm{C}$ turnover, due to higher precipitation and lower litter quality in TMFs, lead to an increased storage of $\mathrm{C}$ on the forest floor and in the mineral soil (Hertel et al. 2003; Schuur 2001; Schuur et al. 2001). Although comparably much is known about the features of aboveground $\mathrm{C}$ allocation in TMFs, it is still unclear how environmental and nutrient conditions influence total belowground carbon allocation (TBCA) and if increasing TBCA might possibly compensate for the decline in aboveground biomass (Leuschner et al., 2007).

However, forest productivity, soil nutrient cycling and ecosystem $\mathrm{C}$ sequestration do not only change with elevation in TMF. Topography, drainage characteristics, and disturbance history cause a complex pattern of soil properties, nutrient and soil water availability, which overlays elevation gradients in montane regions. The resulting small-scale heterogeneity also affects forest ecosystem functioning, including nutrient and carbon accumulation in thick organic layers and lower aboveground tree productivity at ridge positions compared to the slopes (Homeier 2008; Homeier et al. 2010; Tanner 1977).

\subsection{Soil trace gas fluxes in tropical montane forests}

Soils naturally act as sources or sinks for several trace gases and thus co-regulate the global budgets of these gases (Conrad 1996). Climate relevant trace gases interacting with soils are carbon dioxide $\left(\mathrm{CO}_{2}\right)$, nitrous oxide $\left(\mathrm{N}_{2} \mathrm{O}\right)$ and methane $\left(\mathrm{CH}_{4}\right)$, which are three of the five most important greenhouse gases (Forster et al. 2007). A fourth gas emitted by forest soils, nitric oxide (NO) plays a crucial role in regulating troposphere ozone concentrations (Crutzen 1979). Carbon dioxide is produced in soils mainly by root respiration and heterotrophic respiration of soil organisms. Nitrous oxide and NO are produced in soils largely during nitrification and denitrification processes (Davidson et al. 2000; Firestone \& Davidson 1989). Finally, $\mathrm{CH}_{4}$ is an important product of anaerobic organic matter decomposition in soils (Conrad 1996). However, soils act as net $\mathrm{CH}_{4}$ sink under aerobic conditions and microbial oxidation in aerated upland soils is the primary biotic sink for atmospheric $\mathrm{CH}_{4}$ (Potter et al. 1996). 
Since soil trace gas production and consumption processes are related to microbial activity, the amount of gas exchange with the atmosphere is largely regulated by soil temperature, moisture, texture and aeration as well as substrate availability (Conrad 1996). According to the conceptual "hole in the pipe" model (HIP), rates of soil $\mathrm{N}$ cycling and $\mathrm{N}$ availability control the total amount of $\mathrm{N}_{2} \mathrm{O}+\mathrm{NO}$ production, whereas soil moisture regulates the relative importance of the two gases and the rates of gas diffusion through the soil (Firestone \& Davidson 1989). Tropical soils play a major role for the mitigation of soil trace gas fluxes, since they are considered the largest natural terrestrial source of $\mathrm{N}_{2} \mathrm{O}$ (Bouwman et al. 1995) and to account for 10 to $20 \%$ of the annual soil $\mathrm{CH}_{4}$ consumption (Potter et al. 1996; Prather et al. 2001). Furthermore, tropical forests cycle more than $10 \%$ of the atmospheric $\mathrm{CO}_{2}$, through photosynthesis, respiration and microbial decay (Malhi, 2005) every year. Estimates on the source and sink strengths of tropical soils regarding these trace gases are however mainly based on field studies that are heavily biased towards lowland forests. There are few data available about trace gas fluxes and their controlling factors in TMFs (Davidson et al. 2000; Ishizuka et al. 2005; Keller \& Reiners 1994). Increasing precipitation and decreasing temperatures with elevation, changes of soil moisture, nutrient limitation and the accumulation of organic matter along topographic gradients in TMFs may result in conditions unfavorable for $\mathrm{CO}_{2}, \mathrm{~N}_{2} \mathrm{O}$ and $\mathrm{NO}$ production and $\mathrm{CH}_{4}$ uptake. Studies carried out on trace gas fluxes in TMF suggest that trace gas exchange rates from TMF soils are smaller compared to lowland forests and decline with increasing elevation (Cavelier \& Penuela 1990; Holtgrieve et al. 2006; Köhler et al. 2009a; Köhler et al. 2009b; Matson \& Vitousek 1987; Purbopuspito et al. 2006; Raich 1998). Although studies in temperate regions show strong topography effects on N-oxide emissions (Corre et al. 1996; Meixner \& Eugster 1999), most of the studies done in TMF do not include information on topographic positions. To improve estimations and modelling of trace gas fluxes, the identification of proxies with the potential to predict trace gas fluxes is indispensable, since direct measurement of trace gas fluxes on tropical mountain slopes is challenging (Davidson et al. 2000; Ishizuka et al. 2005; Keller \& Reiners 1994). 


\subsection{Study objectives}

The aim of the present work was to investigate the soil-atmosphere trace gas exchange in tropical montane forests, and to examine if $\mathrm{CO}_{2}, \mathrm{~N}_{2} \mathrm{O}, \mathrm{NO}$ and $\mathrm{CH}_{4}$ fluxes as well as carbon allocation patterns are linked to forest productivity through nutrient availability. The main regulation factors of trace gas fluxes and possible changes in the relationships with elevation and topography were studied. The specific objectives of this study were:

1) To investigate whether forest productivity and soil N-oxide fluxes are linked through $\mathrm{N}$ availability along elevational and topographic gradients in TMFs and if, consequently, forest productivity may be used as a proxy for N-oxide flux estimation.

2) To study atmospheric $\mathrm{CH}_{4}$ exchange of tropical montane forest soils, investigate its biogeochemical controls and the contribution of organic layers to the atmospheric $\mathrm{CH}_{4}$ uptake.

3) To examine the influence of nutrient availability on total belowground carbon allocation along elevation and topographic gradients.

With these aims I tested the following hypotheses:

1) Soil $\mathrm{N}$-oxide fluxes increase with increasing $\mathrm{N}$ availability.

2) Forest productivity increases with increasing soil $\mathrm{N}$ availability

3) Forest productivity is a good proxy for N-oxide fluxes in such N-limited ecosystems.

4) $\mathrm{CH}_{4}$ fluxes decrease with increasing $\mathrm{N}$ availability.

5) Soil $\mathrm{CH}_{4}$ uptake decreases with increasing elevation and with decreasing soil diffusivity.

6) Soil organic layers do not, or only little, contribute to the uptake of atmospheric $\mathrm{CH}_{4}$ in tropical montane forests.

7) Total belowground carbon allocation increases with decreasing nutrient availability. 


\subsection{Study area and experimental design}

The study was carried out within or close to the Podocarpus National Park (PNP) in the Province Zamora-Chinchipe between the cities of Loja and Zamora in southern Ecuador (Figure 1.1). The PNP, founded in 1982 by the Instituto Ecuatoriano Forestal y de Areas Naturales $y$ Vida Silvestre on an area of $1462.8 \mathrm{~km}^{2}$, forms one of the last continuous primary forests in southern Ecuador (Calderón 2002) and stretches from $900 \mathrm{~m}$ to $3600 \mathrm{~m}$ in elevation. The location of the PNP, in the transition zone between the northern and southern Andes and between the Amazonian and the Pacific ecozones (Beck \& Richter 2008) contributes to the fact, that the PNP is a biodiversity hotspot supporting about 3000 to 4000 vascular plant species and showing a high level of endemism (Madsen 1989).

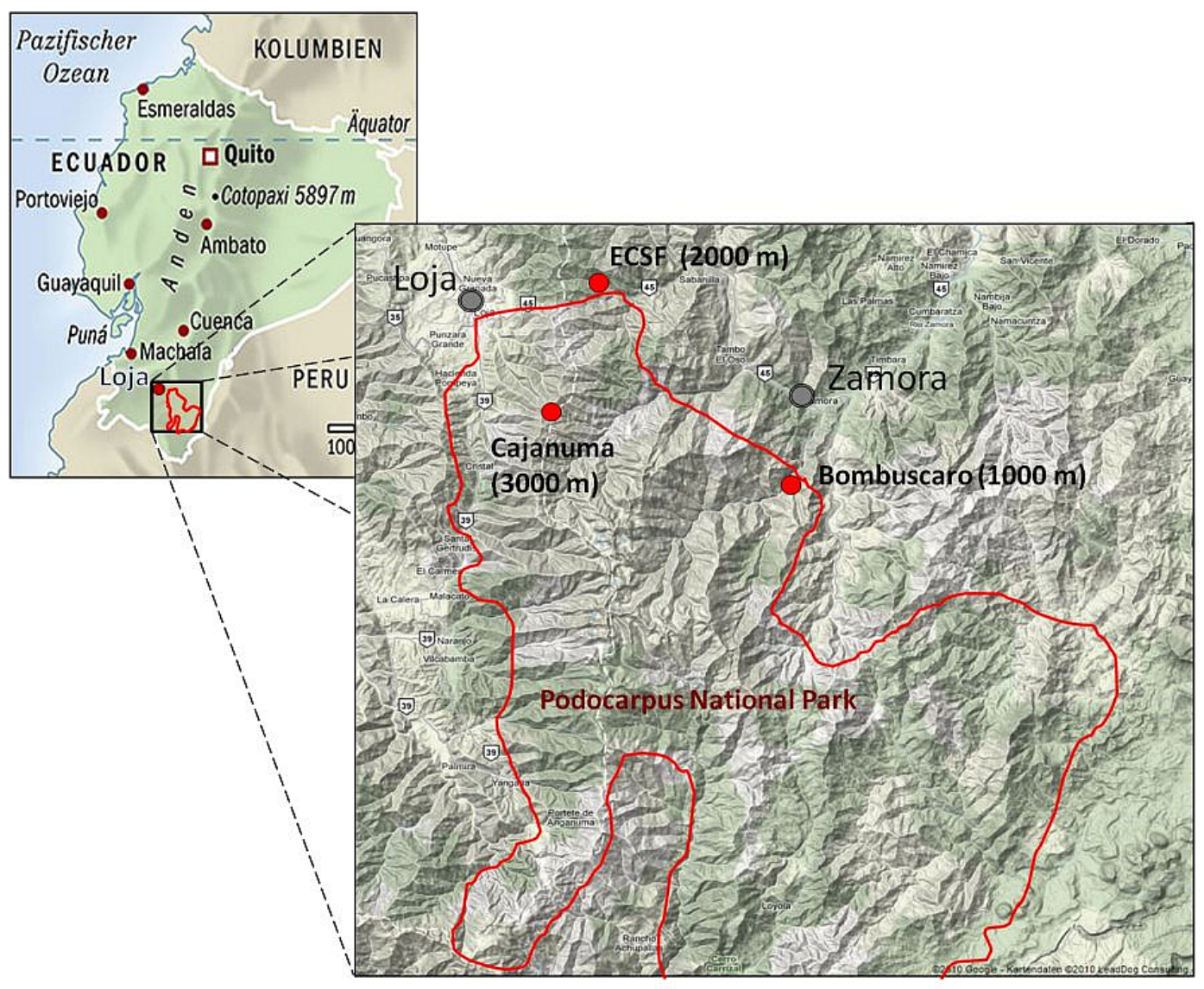

Figure 1.1: Location of the three study sites within and close to the National Park Podocarpus in southern Ecuador. Map sources: Small map: http://blog.blumenbutler.de. Large map: Google Maps 2010. Borders of the national park: Ministerio del Ambiente, Ecuador. 
For this study three sites were selected along an elevation gradient from $1000 \mathrm{~m}$ to $3000 \mathrm{~m}$ within the PNP and the adjacent Reserva Biológica San Francisco: 990-1200 m a.s.1. (Bombuscaro, 04 $06^{\prime} \mathrm{S}, 78^{\circ}$ 58' W), 1800-2100 m a.s.1. (Estaciòn Científica San Francisco, ECSF, 03 $58^{\prime} \mathrm{S}, 79^{\circ} 04^{\prime} \mathrm{W}$ ) and 2800-3000 m a.s.1. (Cajanuma, 04 06' S, 79 $11^{\circ} \mathrm{W}$ ) (Figure $1.1)$.
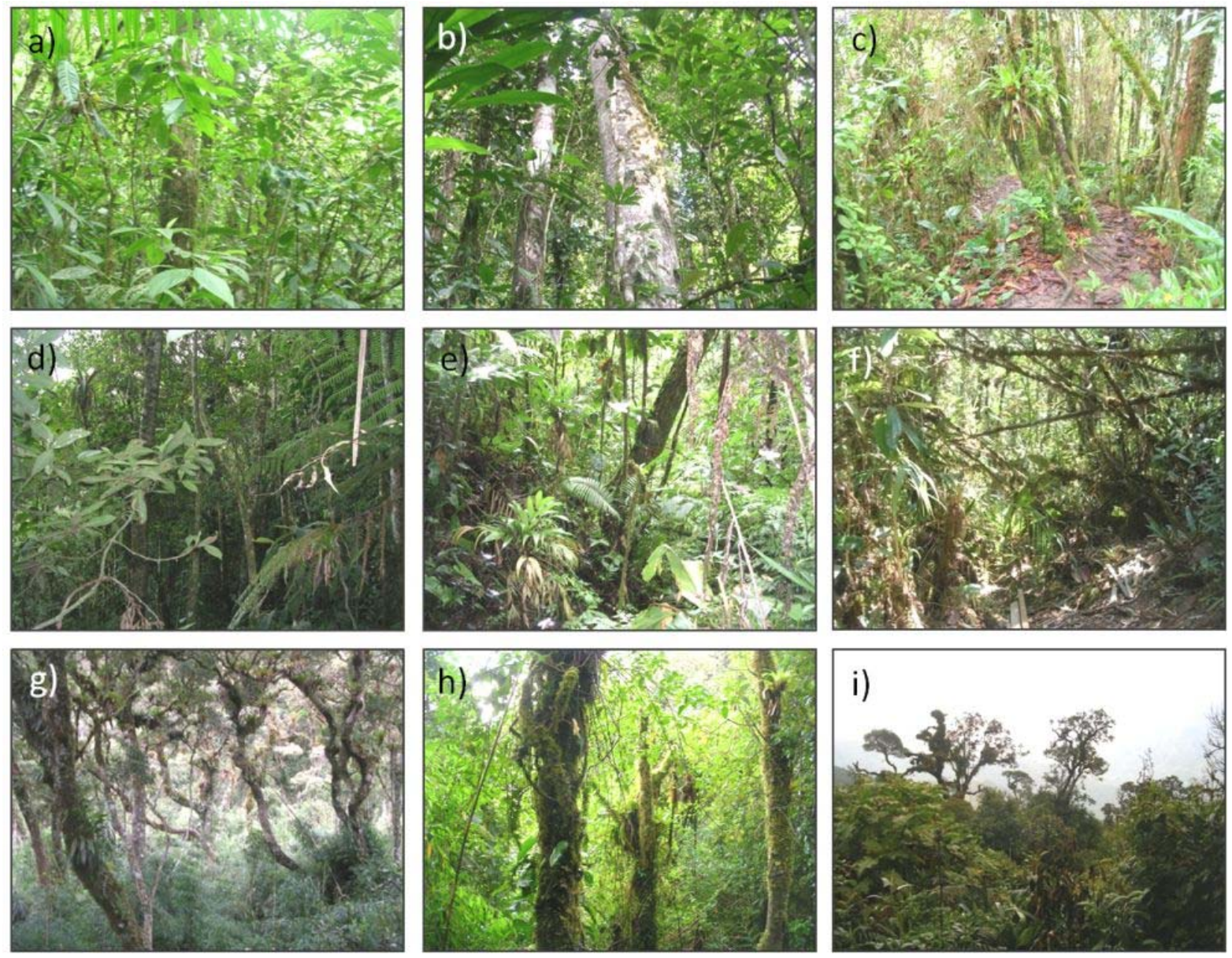

Figure 1.2: Pictures of the forests at three landscape positions along the elevation gradient: a-c) $1000 \mathrm{~m}$ site, d-f) $2000 \mathrm{~m}$ site, g-i) $3000 \mathrm{~m}$ site (from left to right within rows: lower slope, midslope, ridge). Photographs: Katrin Wolf

The natural vegetation is premontane forest with tree heights of 20 to $30 \mathrm{~m}$ at the $1000 \mathrm{~m}$ site (Figure $1.2 \mathrm{a}-\mathrm{c}$ ), lower montane forest, with tree heights of 15 to $25 \mathrm{~m}$ at the $2000 \mathrm{~m}$ site (Figure $1.2 \mathrm{~d}-\mathrm{f}$ ) and upper montane forest, with tree heights of 6 to $12 \mathrm{~m}$ at the $3000 \mathrm{~m}$ site (Figure $1.2 \mathrm{~g}-$ i). Along with tree height, tree physiognomy changed toward reduced slenderness of stems and 
smaller mean diameters. Forests are more and more characterized by higher stem densities and a decline in overall aboveground tree biomass (Homeier et al. 2010; Takyu et al. 2005). Similar changes in forest structure and plant physiognomy as with elevation occurred along topographic gradients, from lower slopes to ridge positions, within each respective elevational zones (Homeier et al. 2010). At each of the three elevations 18 plots $(20 \times 20 \mathrm{~m})$ were installed such that they covered the three main topographic positions: lower slope, midslope and ridge. Each of the 54 plots contained four chambers for soil trace gas flux measurement and six litter traps, installed in a random design along two orthogonal transects.

\subsection{Methodological outline of soil trace gas flux measurements}

We measured soil fluxes of $\mathrm{CO}_{2}, \mathrm{~N}_{2} \mathrm{O}$ and $\mathrm{CH}_{4}$ using static closed chambers (Figure $1.3 \mathrm{a}$ ) bimonthly over a period of one year from May 2008 until May 2009. Gas samples were analyzed using a gas chromatograph equipped with an electron capture detector (ECD) to measure $\mathrm{CO}_{2}$ and $\mathrm{N}_{2} \mathrm{O}$ and a flame ionization detector (FID) to determine $\mathrm{CH}_{4}$ (Figure $1.3 \mathrm{~b}$ ). Nitric oxide (NO) was measured in the field using open dynamic chambers and analyzed with a chemiluminescence detector, after $\mathrm{NO}$ oxidation to $\mathrm{NO}_{2}$ by a chrome oxide catalyst (Figure $1.3 \mathrm{c})$.
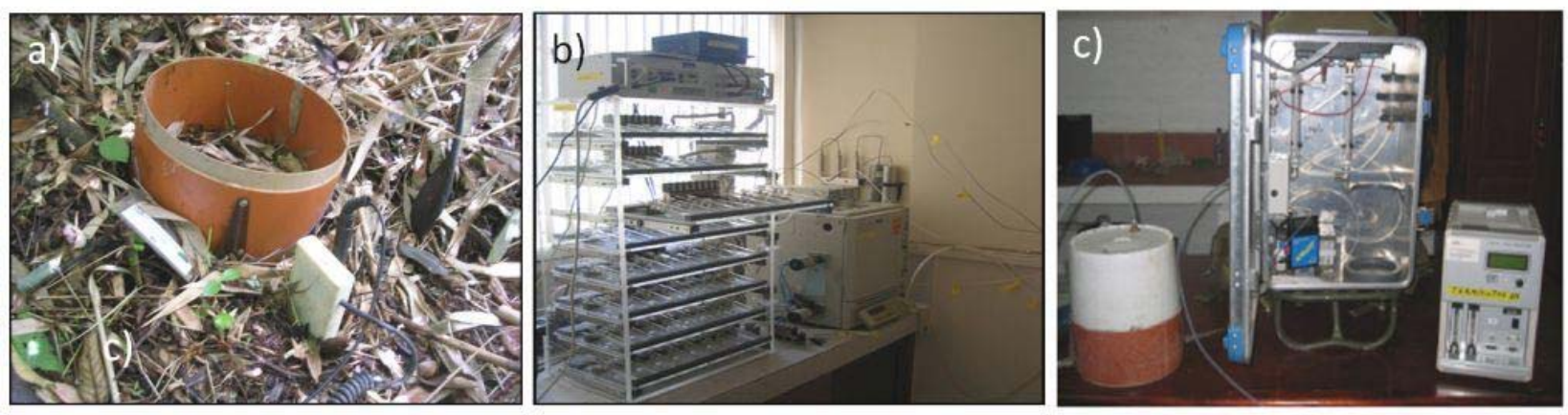

Figure 1.3: Field and laboratory equipment for soil trace gas flux measurements. a) Chamber base for static and open dynamic chamber measurements with thermometer and hydrometer for concomitant temperature and soil moisture measurements, b) gas chromatograph with autosampler and glass vials for the measurement of $\mathrm{CO}_{2}, \mathrm{~N}_{2} \mathrm{O}$ and $\mathrm{CH}_{4}$, and c) $\mathrm{LMA-3D} \mathrm{NO}_{2}$ Analyzer for NO measurement with the closed chamber. Photographs: Katrin Wolf and Guntars O. Martinson. 
Concomitantly to every gas sampling soil temperature, gravimetric soil moisture and the concentration of extractable ammonium $\left(\mathrm{NH}_{4}{ }^{+}\right)$and nitrate $\left(\mathrm{NO}_{3}{ }^{-}\right)$in the upper $5 \mathrm{~cm}$ of the soil was determined.

Furthermore, we conducted a laboratory incubation experiment to investigate potential $\mathrm{CH}_{4}$ uptake activity of different soil substrates and the texture effect on potential $\mathrm{CH}_{4}$ uptake at different soil depths. More detailed descriptions of the study sites and the methodologies for trace gas and auxiliary measurements, as well as for the determination soil properties and forest productivity are provided in the Material and Methods sections of the Chapters 2 to 4. 


\subsection{References}

Aiba S \& Kitayama K (1999) Structure, composition and species diversity in an altitudesubstrate matrix of rain forest tree communities on Mount Kinabalu, Borneo. Plant Ecology 140: 139-157.

Ashton PS (2003) Floristic zonation of tree communities on wet tropical mountains revisited. Perspectives in Plant Ecology, Evolution and Systematics 6: 87-104.

Beck E \& Richter M (2008) Ecological aspects of a biodiversity hotspot in the Andes of southern Ecuador. In: Gradstein SR, Homeier J \& Gansert D (Eds) The tropical mountain forest Pattern and Processes in a biodiversity hotspot pp 195-217). Universitätsverlag Göttingen, Göttingen.

Bouwman AF, Vanderhoek KW \& Olivier JGJ (1995) Uncertainties in the global source distribution of nitrous-oxide. Journal of Geophysical Research-Atmospheres 100: 27852800 .

Bruijnzeel LA \& Veneklaas EJ (1998) Climatic conditions and tropical, montane forest productivity: The fog has not lifted yet. Ecology 79: 3-9.

Bubb P, May L \& Sayer J (2004) Cloud Forest Agenda. UNEP-WCMC,Cambridge,UK.

Calderón S (2002) El Parque Nacional Podocarpus y fundamentos legales que lo respaldan. In: Aguirre M, Z., Madsen JE, Cotton E \& Balslev H (Eds) Botánica Austroecuatoriana. Estudios sobre los recursos vegetales en las provincias de El Oro, Loja y ZamoraChinchipe. pp 433-451). Ediciones Abya-Yala, Quito, Ecuador.

Cavelier J \& Penuela MC (1990) Soil respiration in the cloud forest and dry decisuous forest of Sierra de Macuira, Colombia Biotropica 22: 346-352.

Clark DA (2007) Detecting tropical forests' responses to global climatic and atmospheric change: Current challenges and a way forward. Biotropica 39: 4-19.

Conrad R (1996) Soil microorganisms as controllers of atmospheric trace gases (H-2, CO, CH4, OCS, N2O, and NO). Microbiological Reviews 60: 609-\&.

Corre MD, van Kessel C \& Pennock DJ (1996) Landscape and seasonal patterns of nitrous oxide emissions in a semiarid region. Soil Science Society of America Journal 60: 1806-1815

Crutzen PJ (1979) Role of $\mathrm{NO}$ and $\mathrm{NO}_{2}$ in the chemistry of the troposphere and stratosphere. Annual Review of Earth and Planetary Sciences 7: 443-472.

Davidson EA, Keller M, Erickson HE, Verchot LV \& Veldkamp E (2000) Testing a conceptual model of soil emissions of nitrous and nitric oxides. Bioscience 50: 667-680.

FAO (2000) Global Forest Recources Assessment 2000 - Main report (FRA 2000). Food and Agriculture Organization of the United Nations (FAO), Rome.

Firestone MK \& Davidson EA (1989) Microbiological basis of $\mathrm{NO}$ and $\mathrm{N}_{2} \mathrm{O}$ production and consumption in soil. In: Andreae MO \& Schimel DS (Eds) Exchange of Trace Gases between Terrestrial Ecosystems and the Atmosphere pp 7-21). John Wiley\&Sons, New York.

Fischlin A, Midgley GF, Price JT, Leemans R, Gopal B, Turley C, Rounsevell MDA, Dube OP, Tarazona J \& Velichko AA (2007) Fischlin, A., G.F. Midgley, J.T. Price, R. Leemans, B. Gopal, C. Turley, M.D.A. Rounsevell, O.P. Dube, J. Tarazona, A.A. Velichko,. In: Parry ML, Canziani OF, Palutikof JP, van der Linden PJ \& Hanson CE (Eds) Climate Change 2007: Impacts, Adaptation and Vulnerability. Contribution of Working Group II to the Fourth Assessment Report of the Intergovernmental Panel on Climate Change pp 211272). Cambridge University Press, Cambridge. 
Forster P, V. Ramaswamy, P. Artaxo, T. Berntsen, R. Betts, D.W. Fahey, J. Haywood, J. Lean, D.C. Lowe, G. Myhre, J. Nganga, R. Prinn, G. Raga, M. Schulz \& Dorland RV (2007) Changes in Atmospheric Constituents and in Radiative Forcing. In: Solomon S., D. Qin, M. Manning, Z. Chen, M. Marquis, K.B. Averyt, M.Tignor \& Miller HL (Eds) Climate Change 2007:The Physical Science Basis. Contribution of Working Group I to the Fourth Assessment Report of the Intergovernmental Panel on Climate Change. Cambridge University Press, Cambridge, United Kingdom and New York, NY, USA.

Foster P (2001) The potential negative impacts of global climate change on tropical montane cloud forests. Earth-Science Reviews 55: 73-106.

Gerold G (2008) Soil, climate and vegetation of tropical montane forests - a case study from the Yungas, Bolivia In: Gradstein SR, Homeier J \& Gansert D (Eds) The Tropical Mountain Forest - Patterns and Processes in a Biodiversity Hotspot. pp 137-162). Universitätsverlag Göttingen Göttingen.

Gradstein SR (2008) Epiphytes of tropical montane forests - impact of deforestation and climate change. In: Gradstein SR, Homeier J \& Gansert D (Eds) The Tropical Mountain Forest Patterns and Processes in a Biodiversity Hotspot. Universitätsverlag Göttingen, Göttingen.

Grubb PJ (1977) Control of forest growth and distribution on wet tropical mountains: with special reference to mineral nutrition. Annual Review of Ecology and Systematics 8: 83107.

Grubb PJ, Lloyd JR, Pennington TD \& Whitmore TC (1963) A comparison of montane and lowland rain-forest in Ecuador: 1. The structure, physiognomy and floristics. Journal of Ecology 51: 567-\&.

Hedin LO, Brookshire ENJ, Menge DNL \& Barron AR (2009) The Nitrogen Paradox in Tropical Forest Ecosystems. Annual Review of Ecology Evolution and Systematics 40: 613-635.

Hertel D, Leuschner C \& Hölscher D (2003) Size and Structure of Fine Root Systems in Oldgrowth and Secondary Tropical Montane Forests (Costa Rica). Biotropica 35: 143-153.

Holtgrieve GW, Jewett PK \& Matson PA (2006) Variations in soil N cycling and trace gas emissions in wet tropical forests. Oecologia 146: 584-594.

Homeier J (2008) The influence of topography on forest structure and regeneration dynamics in an Ecuadorian montane forest. Biodiversity and Ecology Series 2: 97-107.

Homeier J, Breckle S-W, Günter S, Rollenbeck RT \& Leuschner C (2010) Tree diversity, forest structure and productivity along altitudinal and topographical gradients in a species-rich Ecuadorian montane rain forest. Biotropica 42: 140-148.

Homeier J, Werner FA, Gradstein SR, Breckle S-W \& Richter M (2008) Potential vegetation and floristic composition of Andean forests in south Ecuador, with a focus on the RBSF. In: Erwin Beck JB, Ingrid Kottke, Franz Makeschin, Reinhard Mosandl (Ed) Ecological studies: Gradients in tropical mountain ecosystem of Ecuador. Springer-Verlag, Berlin, Heidelberg.

Ishizuka S, Iswandi A, Nakajima Y, Yonemura S, Sudo S, Tsuruta H \& Murdiyarso D (2005) The variation of greenhouse gas emissions from soils of various land-use/cover types in Jambi province, Indonesia. Nutrient Cycling in Agroecosystems 71: 17-32.

Keller M \& Reiners WA (1994) Soil atmosphere exchange of nitrous-oxide, nitric-oxide, and methane under secondary succession of pasture to forest in the Atlantic lowlands of CostaRica. Global Biogeochemical Cycles 8: 399-409.

Köhler B, Corre MD, Veldkamp E \& Sueta JP (2009a) Chronic nitrogen addition causes a reduction in soil carbon dioxide efflux during the high stem-growth period in a tropical 
montane forest but no response from a tropical lowland forest in decadal scale. Biogeosciences Discussions 6: 1-28.

Köhler B, Corre MD, Veldkamp E, Wullaert H \& Wright JS (2009b) Immediate and long-term nitrogen oxide emissions from tropical forest soils exposed to elevated nitrogen imput. Global Change Biology: 15: 2049-2066.

Leuschner C \& Moser G (2008) Carbon allocation and productivity in tropical montane forests. In: Gradstein SR, Jürgen Homeier and Dirk Gansert (eds.) (Ed) The Tropical Mountain Forest - Patterns and Processes in a Biodiversity Hotspot. Universitätsverlag Göttingen, Göttingen.

Leuschner C, Moser G, Bertsch C, Röderstein M \& Hertel D (2007) Large altitudinal increase in tree root/shoot ratio in tropical mountain forests of Ecuador. Basic and Applied Ecology 8: 219-230

Madsen JE (1989) Aspectos generales de la flora y vegetación del Parque Nacional Podocarpus. Boletín informativo sobre biología, conservación, y vida silvestre. pp 59-73). Facultad de Ciéncias Veterinárias, Universidad Nacional de Loja, Loja, Ecuador.

Malhi,Y. (2005) The carbon balance of the tropical forest biome., In:The carbon balance of forest biomes Griffiths,H., Jarvis, P.G.(eds),Taylor and Francis Group, Oxford, England, 217-234.

Marrs RH, Proctor J, Heaney A \& D. MM (1988) Changes in soil nitrogen-mineralization and nitrification along an altitudinal transect in tropical rain forest in Costa Rica. The Journal of Ecology 76: 466-482.

Matson PA \& Vitousek PM (1987) Cross-system comparisons of soil nitrogen transformations and nitrous oxide flux in tropical forest ecosystems. Global Biochemical Cycles 1: 163170.

McGroddy ME, Silver WL, de Oliveira RC, de Mello WZ \& Keller M (2008) Retention of phosphorus in highly weathered soils under a lowland Amazonian forest ecosystem. Journal of Geophysical Research 113: G04012.

Meixner FX \& Eugster W (1999) Effects of landscape pattern and topography on emissions and transport. John Wiley \& Sons Ltd, West Sussex.

Potter CS, Davidson EA \& Verchot LV (1996) Estimation of global biogeochemical controls and seasonality in soil methane consumption. Chemosphere 32: 2219-2246.

Prather M, Ehhalt D, F. Dentener, R. Derwent, E. Dlugokencky, E. Holland, I. Isaksen, J. Katima, V. Kirchhoff, P. Matson, P. Midgley \& Wang M (2001) Atmospheric Chemistry and Greenhouse Gases. In: Houghton JT, Y. Ding, D.J. Griggs, M. Noguer, P.J. van der Linden, X. Dai, K. Maskell \& Johnson CA (Eds) Climate Change 2001: The Scientific Basis. Contribution of Working Group I to the Third Assessment Report of the Intergovernmental Panel on Climate Change $\mathrm{p}$ 239. Cambridge University Press, Cambridge.

Purbopuspito J, Veldkamp E, Brumme R \& Murdiyarso D (2006) Trace gas fluxes and nitrogen cycling along an elevation sequence of tropical montane forests in Central Sulawesi, Indonesia. Global Biogeochemical Cycles 20: 11.

Raich JW (1998) Aboveground productivity and soil respiration in three Hawaiian rain forests. Forest Ecology and Management 107: 309-318.

Richards, P. W (1952) The Tropical Rain Forest: an ecological study, Cambridge University Press. 
Richter M (2008) Tropical mountain forests - distribution and general features. In: Gradstein SR, Jürgen Homeier and Dirk Gansert (eds.) (Ed) The tropical mountain forest. Universitätsverlag Göttingen, Göttingen

Schuur EAG (2001) The effect of water on decomposition dynamics in mesic to wet Hawaiian montane forests. Ecosystems 4: 259-273.

Schuur EAG, Chadwick OA \& Matson PA (2001) Carbon cycling and soil carbon storage in mesic to wet Hawaiian montane forests. Ecology 82: 3182-3196.

Takyu M, Aiba SI \& Kitayama K (2002) Effects of topography on tropical lower montane forests under different geological conditions on Mount Kinabalu, Borneo. Plant Ecology 159: 3549.

Takyu M, Kubota Y, Aiba S, Seino T \& Nishimura T (2005) Pattern of changes in species diversity, structure and dynamics of forest ecosystems along latitudinal gradients in East Asia. Ecological Research 20: 287-296.

Tanner EVJ (1977) Four Montane Rain Forests of Jamaica: A Quantitative Characterization of the Floristics, the Soils and the Foliar Mineral Levels, and a Discussion of the Interrelations. Journal of Ecology 65: 883-918.

Tanner EVJ (1981) The decomposition of leaf litter in Jamaican montane rain forests. Journal of Ecology 69: 263-275.

Tanner EVJ (1985) Jamaican montane forests - nutrient capital and cost of growth. Journal of Ecology 73: 553-568.

Tanner EVJ, Vitousek PM \& Cuevas E (1998) Experimental investigation of nutrient limitation of forest growth on wet tropical mountains. Ecology 79: 10-22.

Vitousek PM (1984) Litterfall, nutrient cycling, and nutrient limitation in tropical forests. Ecology 65: 285-298.

Vitousek PM \& Sanford RLJ (1986) Nutrient Cycling in Moist Tropical Forest. Annual Review of Ecology and Systematics 17: 137-167.

Walker TW \& Syers JK (1976) Fate of phosphorous during pedogenesis. Geoderma 15: 1-19.

Webb EL, Stanfield BJ \& Jensen ML (1999) Effects of topography on rainforest tree community structure and diversity in American Samoa, and implications for frugivore and nectarivore populations. Journal of Biogeography 26: 887-897. 

$\mid \begin{aligned} & \text { CHAPTER } \\ & \mathbf{2}\end{aligned}$

\begin{abstract}
Nitrogen Availability Links Forest Productivity, SoIL Nitrous OXIDE AND Nitric OXIDE FluXes OF a Tropical MONTANE Forest In SOUTHERn ECUADOR
\end{abstract}

Revised version accepted in Global Biogeochemical Cycles 



\subsection{Abstract}

Tropical forests are important sources of the greenhouse gas nitrous oxide $\left(\mathrm{N}_{2} \mathrm{O}\right)$ and of nitric oxide (NO), a precursor of ozone. In tropical montane forests nitrogen limitation is common which affects both soil $\mathrm{N}_{2} \mathrm{O}$ and $\mathrm{NO}$ fluxes and forest productivity. Here we present evidence that forest productivity and $\mathrm{N}$-oxide $\left(\mathrm{N}_{2} \mathrm{O}+\mathrm{NO}\right)$ fluxes are linked through $\mathrm{N}$ availability along elevation and topographic gradients in tropical montane forests. We measured N-oxide fluxes, several indices of $\mathrm{N}$ availability, and forest productivity along an elevation gradient from $1000 \mathrm{~m}$ to $3000 \mathrm{~m}$ and along topographic gradients. Organic layer thickness of the soils increased and $\mathrm{N}$ availability decreased with increasing elevation and along the topographic gradient from the lower slope position to the ridges. Annual $\mathrm{N}_{2} \mathrm{O}$ fluxes ranged from $-0.53 \mu \mathrm{g}(\mathrm{N}) \mathrm{m}^{-2} \mathrm{~h}^{-1}$ to $14.54 \mu \mathrm{g}(\mathrm{N}) \mathrm{m}^{-2} \mathrm{~h}^{-1}$ while NO fluxes ranged from $-0.02 \mu \mathrm{g}(\mathrm{N}) \mathrm{m}^{-2} \mathrm{~h}^{-1}$ to $1.13 \mu \mathrm{g}(\mathrm{N}) \mathrm{m}^{-2} \mathrm{~h}^{-1}$. Both Noxide fluxes and forest productivity increased with increasing $\mathrm{N}$ availability and showed close positive correlations with indices of $\mathrm{N}$ availability (C:N ratio and $\delta{ }^{15} \mathrm{~N}$ signature of litterfall). We interpret the close correlations of $\mathrm{N}$-oxide fluxes with total litterfall and tree basal area increment as evidence that $\mathrm{N}$ availability links $\mathrm{N}$-oxide fluxes and forest productivity. This opens the possibility to include forest productivity as co-variable in predictions of $\mathrm{N}$-oxide fluxes in nitrogen limited tropical montane forests. Especially increment of tree basal area was a promising proxy to predict soil N-oxide fluxes in these $\mathrm{N}$ limited ecosystems, possibly because it better reflects long-term forest productivity than total litterfall.

\subsection{Introduction}

Tropical forest soils are considered the largest natural source of the greenhouse gas nitrous oxide $\left(\mathrm{N}_{2} \mathrm{O}\right)$ with a source strength of $3.0 \mathrm{Tg} \mathrm{N} \mathrm{yr}^{-1}$ (Werner et al. 2007). Additionally, they can produce considerable amounts of nitric oxide (NO), which plays a crucial role regulating troposphere ozone concentrations (Crutzen 1979). Estimates of the source strengths of $\mathrm{N}_{2} \mathrm{O}$ and NO are based on field studies that are still heavily biased towards tropical lowland forests. The few studies on $\mathrm{N}_{2} \mathrm{O}$ and $\mathrm{NO}$ fluxes carried out in tropical montane forests show that the trace gas emissions decrease with increasing elevation (Hall et al. 2004; Purbopuspito et al. 2006). Measurements of nitrogen oxide fluxes from tropical montane forests range between 0.01 and $3.75 \mathrm{~kg}(\mathrm{~N}) \mathrm{ha}^{-1} \mathrm{yr}^{-1}$ for $\mathrm{N}_{2} \mathrm{O}$ (Breuer et al. 2000; Holtgrieve et al. 2006; Ishizuka et al. 2005; 
Köhler et al. 2009; Purbopuspito et al. 2006) and between 0.03 and $0.4 \mathrm{~kg}(\mathrm{~N}) \mathrm{ha}^{-1} \mathrm{yr}^{-1}$ for NO, an estimate that is based on two studies only (Davidson \& Kingerlee 1997). The relative wide range of $\mathrm{N}$-oxide fluxes reported may reflect the complex pattern of soil properties, nutrient and soil water availability caused by topography, drainage characteristics and disturbance history that overlay elevation gradients in montane regions. Such small-scale heterogeneity potentially affects fluxes of $\mathrm{N}_{2} \mathrm{O}$ and $\mathrm{NO}$ and forest productivity. Although studies in temperate regions show strong topography effects on N-oxide emissions (Corre et al. 1996; Meixner \& Eugster 1999), most of the studies done in tropical montane forests do not include information on topographic positions.

Direct measurements of $\mathrm{N}_{2} \mathrm{O}$ and $\mathrm{NO}$ fluxes in the field are laborious and challenging, which is why several studies have been carried out to test proxies that may have the potential to predict N-oxide fluxes (Davidson et al. 2000; Ishizuka et al. 2005; Keller \& Reiners 1994). The conceptual "hole-in-the-pipe model" (HIP) explains the main controls on $\mathrm{N}_{2} \mathrm{O}$ and $\mathrm{NO}$ fluxes. Rates of $\mathrm{N}$ cycling and $\mathrm{N}$ availability control the total amount of $\mathrm{N}_{2} \mathrm{O}+\mathrm{NO}$ produced, whereas soil moisture regulates the relative importance of the two gases by influencing the main $\mathrm{N}_{2} \mathrm{O}$ and NO producing processes nitrification and denitrification through the gas diffusion rate of the soil (Davidson et al. 2000; Firestone \& Davidson 1989). Some indices of N cycling rates and N availability (e.g. soil mineral $\mathrm{N}$, net $\mathrm{N}$ mineralization and net $\mathrm{N}$ nitrification) are temporally and spatially highly variable, which limits the applicability of these indices, despite reports of positive correlations with $\mathrm{N}$ oxide fluxes (Veldkamp et al. 1999). C:N ratios and $\delta^{15} \mathrm{~N}$ signatures of litterfall are more integrative indices of the long-term N cycle (Kahmen et al. 2008; Robinson 2001) making them more promising predictors of $\mathrm{N}_{2} \mathrm{O}$ and NO fluxes (Davidson et al. 2000; Purbopuspito et al. 2006).

In contrast to many lowland forests, productivity of tropical montane forests is limited by $\mathrm{N}$, or nitrogen and phosphorous (P) together (Tanner et al. 1998). This appears to be mainly related to the soil development where forest productivity on young soils (common in tropical montane forests) tends to be N-limited, whereas forest productivity on heavily weathered soils (common in tropical lowland forests) tends to be P-limited (Walker \& Syers 1976). Further evidence of N limitation comes from slow net and gross $\mathrm{N}$ mineralization rates in montane forest soils compared to lowland forest soils (Arnold et al. 2009; Marrs et al. 1988) and lower $\delta{ }^{15} \mathrm{~N}$ 
signatures of leaves and litter (Martinelli et al. 1999). The microbial processes of nitrification (responsible for $\mathrm{NO}, \mathrm{N}_{2} \mathrm{O}$ and $\mathrm{NO}_{3}{ }^{-}$production) and denitrification (responsible for $\mathrm{NO}, \mathrm{N}_{2} \mathrm{O}$ and $\mathrm{N}_{2}$ production) discriminate against ${ }^{15} \mathrm{~N}$, thus leading to ${ }^{15} \mathrm{~N}$ enrichment of soil and plant material in the ecosystem (Houlton \& Bai 2009). An N-limited ecosystem, with small $\mathrm{N}$ losses through leaching and gas emissions therefore displays lower $\delta^{15} \mathrm{~N}$ signatures compared to ecosystems where more $\mathrm{N}$ is lost relative to $\mathrm{N}$ cycling rates (Amundson et al. 2003; Corre et al. 2010; Houlton et al. 2006). Finally, low $\mathrm{N}$ concentration and high $\mathrm{C}: \mathrm{N}$ ratios in leaves and litter of montane forests indicate $\mathrm{N}$ limitation of tree growth (Tanner et al. 1998).

In summary, there is evidence that in tropical montane forests forest productivity is limited by $\mathrm{N}$ and that $\mathrm{N}$-oxide fluxes depend on $\mathrm{N}$ cycling rates and $\mathrm{N}$ availability (Corre et al. 2010). In the present study our goal was to analyze whether forest productivity and $\mathrm{N}$-oxide fluxes are linked through $\mathrm{N}$ availability along elevation and topographic gradients in tropical montane forests. Our hypotheses were the following: 1) N-oxide fluxes increase with increasing $\mathrm{N}$ availability, 2) forest productivity increases with increasing $\mathrm{N}$ availability in $\mathrm{N}$-limited ecosystems, and 3) forest productivity shows good correlations with $\mathrm{N}$-oxide fluxes in such $\mathrm{N}$-limited ecosystems. We tested our hypotheses by measuring $\mathrm{N}_{2} \mathrm{O}$ and $\mathrm{NO}$ fluxes, several indices of $\mathrm{N}$ availability, and forest productivity during one year along elevation and topographic gradients in natural tropical montane forests in southern Ecuador. Our results show that both N-oxide fluxes and forest productivity are linked through $\mathrm{N}$ availability and we suggest that predictions of soil $\mathrm{N}_{2} \mathrm{O}+\mathrm{NO}$ fluxes of N-limited ecosystems can be improved using forest productivity as a co-variable.

\subsection{Material and Methods}

\section{Study Area}

The study area is located in the Cordillera del Consuelo, which forms part of the eastern chain of the Andes in southern Ecuador. Three study sites were selected along an elevation gradient (Table 2.1): 990-1200 m a.s.1. (Bombuscaro, 04 06' S, 78 58' W, hereafter called the ' $1000 \mathrm{~m}$ site'), 1800-2100 m a.s.1. (San Francisco, 03 58' S, 79 04' W, hereafter called the '2000 $\mathrm{m}$ site') and 2800-3000 $\mathrm{m}$ a.s.1. (Cajanuma, 04 06' S, 79 $11^{\circ} \mathrm{W}$, hereafter called the '3000 m site'). The $1000 \mathrm{~m}$ site is located close to the city of Zamora, Zamora-Chinchipe 
province within the Podocarpus National Park (PNP). Natural vegetation consists of "premontane rain forest" (Homeier et al. 2008) and most important tree families are Moraceae, Rubiaceae and Melastomataceae. The $2000 \mathrm{~m}$ site is situated between the cities of Loja and Zamora within the Reserva San Francisco (RSF), a private reserve that borders the PNP. Vegetation can be classified as "lower montane rain forest" (Homeier et al. 2008). Most important tree families of the $2000 \mathrm{~m}$ site are Lauraceae, Euphorbiaceae, Melastomataceae and Rubiaceae. The $3000 \mathrm{~m}$ site is located south of the city of Loja within the PNP. Forest is classified as "upper montane rain forest" (Homeier et al. 2008). Cunoniaceae, Clusiaceae and Melastomataceae are the most important tree families of this site. Stand height decreased with elevation and from the lower slope positions to the ridge positions within every site. The annual mean temperature decreased from $19.4^{\circ} \mathrm{C}$ at the $1000 \mathrm{~m}$ site to $9.4^{\circ} \mathrm{C}$ at the $3000 \mathrm{~m}$ site, annual precipitation increased from $2230 \mathrm{~mm}$ at $1000 \mathrm{~m}$, and $1950 \mathrm{~mm}$ at $2000 \mathrm{~m}$, to $4500 \mathrm{~mm}$ at $3000 \mathrm{~m}$ (Table 2.1) (Moser et al. 2007). Rainfall showed little seasonality (Emck 2007). For most of the study area, Paleozoic metamorphic schists and sandstones with some quartz veins form the parent material for soil development. Only at the $1000 \mathrm{~m}$ site soil parent material of half of the plots consists of deeply weathered granitic rock of the Jurassic Zamora granitoide formation (Litherland et al. 1994).

\subsubsection{Experimental design}

We installed 54 plots $(20 \times 20 \mathrm{~m})$ at three elevation levels $(1000 \mathrm{~m}, 2000 \mathrm{~m}$, and $3000 \mathrm{~m})$ forming an elevation transect from $1000 \mathrm{~m}$ to $3000 \mathrm{~m}$. Eighteen plots per elevation were distributed over the topographic positions lower slope, midslope and ridge, with six replicates each. Vertical deviation of plots from the pre-determined levels was never more than $200 \mathrm{~m}$. All plots were covered by mature, closed-canopy forest that is representative for the respective topographic position. Plot size was small enough to ensure homogeneity of environmental factors and forest structure. Each plot contained six litter traps and four chamber bases, which we placed in a random design along two orthogonal transects. For the calculations, we corrected plot size for inclination. 
N - Availability Links Forest Productivity, Soil N $\mathrm{N}_{2} \mathrm{O}$ AND NO FluXes | 23

Table 2.1: Site characteristics of the topographic positions across the elevation gradient.

\begin{tabular}{|c|c|c|c|c|c|c|c|c|c|}
\hline & \multicolumn{3}{|c|}{$1000 \mathrm{~m}$} & \multicolumn{3}{|c|}{$2000 \mathrm{~m}$} & \multicolumn{3}{|c|}{$3000 \mathrm{~m}$} \\
\hline & lower slope & midslope & ridge & lower slope & midslope & ridge & lower slope & midslope & ridge \\
\hline Height a.s.l. (m) & & $990-1200$ & & & $1800-2100$ & & & $2800-3000$ & \\
\hline Air temperature $\left({ }^{\circ} \mathrm{C}\right)^{\mathrm{a}}$ & & 19.4 & & & 15.7 & & & 9.4 & \\
\hline Precipitation $\left(\mathrm{mm} \mathrm{yr}^{-1}\right)^{\mathrm{a}}$ & & 2230 & & & 1950 & & & 4500 & \\
\hline Gravimetric moisture $\left(\mathrm{g} \mathrm{g}^{-1}\right)^{\mathrm{b}}$ & $1.0(0.2) \mathrm{aA}$ & $0.9(0.2) \mathrm{aA}$ & $1.8(0.2) \mathrm{bA}$ & $1.7(0.3) \mathrm{aB}$ & $2.1(0.3) \mathrm{aB}$ & $4.3(0.1) \mathrm{bB}$ & $2.1(0.2) \mathrm{aB}$ & $2.9(0.3) \mathrm{bC}$ & $4.5(0.2) \mathrm{cB}$ \\
\hline Organic layer thickness $(\mathrm{cm})^{\mathrm{b}}$ & $2.5(0.7)$ & $2.6(1.0) \mathrm{A}$ & $6.5(1.9) \mathrm{A}$ & $4.0(0.9) \mathrm{a}$ & $12.2(3.1) \mathrm{aB}$ & $24.0(2.9) \mathrm{cB}$ & $6.6(0.7) \mathrm{a}$ & $14.2(1.6) \mathrm{bB}$ & $22.2(3.4) \mathrm{cB}$ \\
\hline \multicolumn{10}{|l|}{ Organic layer } \\
\hline $\mathrm{pH}\left(\mathrm{H}_{2} \mathrm{O}\right)^{\mathrm{b}}$ & $4.9(0.5) \mathrm{a}$ & $4.8(0.6) \mathrm{a}$ & $3.7(0.1) \mathrm{b}$ & $4.6(0.2) \mathrm{a}$ & $4.8(0.5) \mathrm{a}$ & $3.4(0.1) \mathrm{b}$ & $4.0(0.3)$ & $3.7(0.1)$ & $3.6(0.1)$ \\
\hline $\mathrm{C}: \mathrm{N}^{\mathrm{b}}$ & $18.5(0.7) \mathrm{A}$ & $18.6(1.5) \mathrm{A}$ & $20.5(0.7) \mathrm{A}$ & $15.7(0.8) \mathrm{aB}$ & $15.6(0.6) \mathrm{aA}$ & $21.1(0.7) \mathrm{bA}$ & $20.5(0.8) \mathrm{aA}$ & $23.9(1.4) \mathrm{bB}$ & $26.7(1.3) \mathrm{cB}$ \\
\hline$\delta^{15} \mathrm{~N}(\% \mathrm{o})^{\mathrm{b}}$ & $3.7(0.5) \mathrm{A}$ & $2.1(0.7) \mathrm{A}$ & $1.9(0.5)$ & $4.0(0.3) \mathrm{aA}$ & $3.0(0.2) \mathrm{aA}$ & $1.0(0.4) \mathrm{b}$ & $1.4(0.2) \mathrm{aB}$ & $0.2(0.3) \mathrm{bB}$ & $0.6(0.2) \mathrm{ab}$ \\
\hline Total P (mg (P) $\left.\mathrm{g}^{-1}\right)^{\mathrm{b}}$ & $1.1(0.1)$ & $1.2(0.1) \mathrm{A}$ & $0.6(0.02) \mathrm{A}$ & $1.2(0.1) \mathrm{a}$ & $1.1(0.2) \mathrm{aA}$ & $0.5(0.0) \mathrm{bAB}$ & $0.8(0.1) \mathrm{aA}$ & $0.6(0.1) \mathrm{abB}$ & $0.4(0.02) \mathrm{bB}$ \\
\hline \multicolumn{10}{|l|}{ Mineral soil layer (Ah) } \\
\hline $\mathrm{pH}\left(\mathrm{H}_{2} \mathrm{O}\right)^{\mathrm{b}}$ & $5.0(0.3) \mathrm{A}$ & $5.1(0.4) \mathrm{A}$ & $4.2(0.1)$ & $4.6(0.2) \mathrm{aA}$ & $4.7(0.4) \mathrm{aA}$ & $3.7(0.1)$ & $3.7(0.1) \mathrm{B}$ & $3.7(0.0) \mathrm{B}$ & $3.7(0.1)$ \\
\hline Base Saturation $(\%)^{\mathrm{b}}$ & $65.9(19.6) \mathrm{aA}$ & $59.9(18.2) \mathrm{aA}$ & $2.2(0.4) \mathrm{b}$ & $46.3(14.9) \mathrm{A}$ & $42.5(17.3) \mathrm{A}$ & $3.3(0.7)$ & $8.2(0.5) \mathrm{B}$ & $6.9(1.3) \mathrm{B}$ & $8.3(1.5)$ \\
\hline $\mathrm{C}: \mathrm{N}^{\mathrm{b}}$ & $16.3(0.6) \mathrm{aA}$ & $15.0(0.7) \mathrm{a}$ & $21.3(1.2) \mathrm{bB}$ & $13.2(1.1) \mathrm{B}$ & $14.1(1.5)$ & $17.0(0.8) \mathrm{A}$ & $14.2(0.2) \mathrm{aAB}$ & $18.0(1.1) \mathrm{b}$ & $22.3(1.0)_{\mathrm{cB}}$ \\
\hline$\delta^{15} \mathrm{~N}(\% \mathrm{o})^{\mathrm{b}}$ & $5.8(0.1) \mathrm{A}$ & $4.7(0.3) \mathrm{A}$ & $5.2(0.1)$ & $5.9(0.3) \mathrm{A}$ & $5.1(0.2) \mathrm{A}$ & $5.2(0.2)$ & $4.1(0.3) \mathrm{B}$ & $3.4(0.3) \mathrm{B}$ & $4.8(0.6)$ \\
\hline Total P $\left(m g(P) g^{-1}\right)^{b}$ & $0.7(0.2)$ & $0.8(0.2) \mathrm{A}$ & $0.6(0.1) \mathrm{A}$ & $0.5(0.1) \mathrm{a}$ & $0.7(0.1) \mathrm{aA}$ & $0.2(0.0) \mathrm{bB}$ & $0.3(0.0)$ & $0.2(0.0) \mathrm{B}$ & $0.1(0.0) \mathrm{B}$ \\
\hline Sand $(\%)$ & $42.4(8.6) \mathrm{A}$ & $46.9(8.9)$ & $33.0(7.3)$ & $26.7(2.1) \mathrm{AB}$ & $25.8(5.3)$ & $23.9(2.9)$ & $21.8(3.9) \mathrm{B}$ & $32.1(6.7)$ & $36.0(4.8)$ \\
\hline Silt $(\%)^{b}$ & $30.6(7.5) \mathrm{A}$ & $35.8(8.2)$ & $35.6(5.8) \mathrm{A}$ & $55.3(3.0) \mathrm{B}$ & $53.1(3.8)$ & $60.9(1.8) \mathrm{B}$ & $57.5(0.3) \mathrm{B}$ & $49.7(2.5)$ & $50.0(2.0) \mathrm{AB}$ \\
\hline Clay $(\%)^{b}$ & $26.9(2.6) \mathrm{a}$ & $17.3(2.3) \mathrm{b}$ & $31.5(2.1) \mathrm{aA}$ & $18.1(2.1)$ & $21.1(2.1)$ & $15.2(2.1) \mathrm{B}$ & $20.7(3.6)$ & $18.2(4.3)$ & $14.1(3.3) \mathrm{B}$ \\
\hline
\end{tabular}

${ }^{\mathrm{a}}$ Moser et al. (2007)

${ }^{b}$ Means $( \pm S E, n=6)$ within rows followed by different letter indicate significant differences among topographic positions at each elevation (small letters) and differences among elevations at each topographic position (capital letters) (one-way ANOVA with Fisher's LSD test at $P \leq 0.05$ ). 


\subsubsection{Soil characterization}

Twelve to sixteen soil profiles per elevation were dug until the underlying parent material was reached $(0.5-1.5 \mathrm{~m}$ depth). We opened the profiles outside the boundaries of the plots under closed canopy and undisturbed, representative vegetation. Bulk density was determined for mineral soil using steel cores $\left(250 \mathrm{~cm}^{3}\right)$ and for the organic layer by measuring the thickness and dry weight of an area of $400 \mathrm{~cm}^{2}$ (Blake \& Hartge 1986; Schlichting \& Stahr. 1995). We expressed moisture content as gravimetric moisture content and as water-filled pore space (WFPS), assuming a particle density of $2.65 \mathrm{~g} \mathrm{~cm}^{-3}$ for mineral soil (Linn \& Doran 1984) and of $1.4 \mathrm{~g} \mathrm{~cm}^{-3}$ for the organic layer (Breuer et al. 2002). Disturbed soil samples for chemical analysis were taken from the organic layer (as a pooled sample covering the whole depth of the organic layer) and from each mineral soil horizon. Oven-dried samples $\left(45^{\circ} \mathrm{C}\right.$ for three days) were sieved and stored in plastic bags until air transport to Germany. All samples were analyzed for total carbon, nitrogen, phosphorous, total base cations and $\mathrm{pH}\left(\mathrm{H}_{2} \mathrm{O}\right)$. In addition, effective cation exchange capacity (ECEC) was measured for the mineral soil horizons. Total $\mathrm{C}$ and $\mathrm{N}$ were determined using ground samples and a CNS Elemental Analyzer (Elementar Vario EL, Hanau, Germany). Total $\mathrm{P}$ and total base cations were measured using Inductively Coupled PlasmaAtomic Emission Spectrometer (ICP-AES; Spectro Analytical Instruments, Kleve, Germany) after pressure digestion in $65 \% \mathrm{HNO}_{3}$ (Heinrichs et al. 1986). ECEC was determined from sieved samples by measuring cations in percolates of soils with unbuffered $1 \mathrm{M} \mathrm{NH}_{4} \mathrm{Cl}$ using ICP-AES (König \& Fortmann 1996). Base saturation was calculated as the percentage of exchangeable base cations ( $\mathrm{Na}, \mathrm{K}, \mathrm{Ca}$ and, $\mathrm{Mg}$ ) of all exchangeable cations. Soil $\mathrm{pH}$ was measured in a suspension of soil in $\mathrm{H}_{2} \mathrm{O}$ with a 1:1 ratio for sieved mineral soil and a 1:10 ratio for material from the organic layer. Texture was determined by sedimentary fractionation of the clay fraction $\left(25^{\circ} \mathrm{C}, 21 \mathrm{~h}, 30 \mathrm{~cm}\right.$ fall height) following the Atterberg method after wet sieving of the sand and coarse silt fraction $(630 \mu \mathrm{m}, 200 \mu \mathrm{m}, 63 \mu \mathrm{m}$ and, $20 \mu \mathrm{m})$ and after destruction of organic matter with $30 \% \mathrm{H}_{2} \mathrm{O}_{2}$ and $\mathrm{Fe}$ oxides with $4 \%$ Na-Dithionite-Citrate solution (Schlichting E. 1995).

We measured $\delta^{15} \mathrm{~N}$ signatures on composite soil samples consisting of four subsamples taken with an auger within one meter distance of the chamber bases. Depending on the depth of the organic layer, we took samples from organic layer $(0-10 \mathrm{~cm}$ depth and if present also $10-20 \mathrm{~cm}$ 
depth) and three depths of the mineral soil $(0-10 \mathrm{~cm}, 10-20 \mathrm{~cm}, 20-30 \mathrm{~cm}$ depth). Samples were dried at $45{ }^{\circ} \mathrm{C}$ for three days, sieved and stored in plastic bags until analysis in Germany. Ground samples were analyzed for $\delta^{15} \mathrm{~N}$ signature using an elemental $\mathrm{C}$ and $\mathrm{N}$ analyzer (NA1500, CE Instruments, Rodano, Milano, Italy) and an isotope ratio mass spectrometer (Delta V Plus, Thermofisher, Bremen, Germany). The isotope signatures were expressed as $\delta^{15} \mathrm{~N}(\%)$ :

$$
\delta{ }^{15} \mathrm{~N}(\%)=\left[\left(\mathrm{R}_{\text {sample }} / \mathrm{R}_{\text {std }}\right)-1\right] \times 10^{3}
$$

where $R_{\text {sample }}={ }^{15} \mathrm{~N} /{ }^{14} \mathrm{~N}$ is the ratio of the sample and $\mathrm{R}_{\text {std }}={ }^{15} \mathrm{~N} /{ }^{14} \mathrm{~N}$ is the ratio of the reference (atmospheric $\mathrm{N}_{2}$ ) (Martinelli et al. 1999).

\subsubsection{Forest structure and productivity}

We approximated forest productivity by annual tree basal area increment and annual total litterfall. In the study plots we made an inventory of all trees with stems $\geq 0.1 \mathrm{~m}$ diameter at breast height $(\mathrm{dbh})$ and their basal area was calculated. After approximately one year we measured all trees again and we calculated the increment of plot basal area as the sum of the individual tree increments per plot over one year (diameter difference between first and second measurement was calculated for one year).

Total litterfall was collected monthly (bi-weekly at $1000 \mathrm{~m})$ from six litter traps $(60 \mathrm{x} 60 \mathrm{~cm})$ per plot. Total litterfall, including leaves, twigs, epiphytes, flowers and fruits, was dried at $60{ }^{\circ} \mathrm{C}$ and weighed. Total litterfall of December 2008 was collected, ground and sent to Germany for analysis. Litter samples of the six litter traps were proportionally pooled for each plot and analyzed for total $\mathrm{C}$ and $\mathrm{N}$, total $\mathrm{P}$, total base cations and $\delta{ }^{15} \mathrm{~N}$ signatures as described above for soil samples.

\subsection{4 $\quad \mathrm{N}_{2} \mathrm{O}$ and NO flux measurements}

We measured $\mathrm{N}_{2} \mathrm{O}$ fluxes from static closed chambers with a base area of $0.044 \mathrm{~m}^{2}$. Six months prior to the first measurements, we installed chamber bases, inserting them approximately $0.02 \mathrm{~m}$ into the soil. The chamber bases were not moved until the end of the 
sampling period. Chambers had a mean volume of 13 liter; lids were equipped with two Luer lock valves for sampling and pressure compensation during sampling. Gas samples were taken at $2,14,26$, and 38 minutes following chamber closure and stored in pre-evacuated glass containers $(60 \mathrm{ml})$. To assure that tubing and glass containers were evacuated and containers were filled to atmospheric pressure, pressure was checked with a manometer during sampling. Gas samples were analyzed using a gas chromatograph (Shimadzu GC-14B, Duisburg, Germany) equipped with an electron capture detector (ECD) combined with an autosampler (Loftfield et al. 1997), which was located in a laboratory near our field sites in Ecuador. We analyzed gas samples typically within 48 hours following sampling. Gas concentrations were calculated by comparing integrated peak areas of samples with four standard gases $\left(320,501,1001\right.$, and $3003 \mathrm{ppb} \mathrm{N}_{2} \mathrm{O}$; Deuste Steiniger GmbH, Mühlhausen, Germany). $\mathrm{N}_{2} \mathrm{O}$ measurements were conducted bimonthly over a period of one year (May 2008 - May 2009).

Nitric oxide (NO) was measured in the field using open dynamic chambers, which were closed for six minutes using the same chamber bases as for $\mathrm{N}_{2} \mathrm{O}$ sampling. Analysis of $\mathrm{NO}$ was conducted using a Drummond LMA-3D $\mathrm{NO}_{2}$ Analyzer with chemiluminescence detector (Drummond Technology, Ontario, Canada). NO was analyzed following oxidation to $\mathrm{NO}_{2}$ using a $\mathrm{CrO}_{3}$ catalyst and reaction with a Luminol solution. As the $\mathrm{CrO}_{3}$ catalyst is sensitive to relative humidity the gas stream was monitored with a portable relative humidity meter (GFTH 95, Greisinger electronic GmbH, Regenstauf, Germany) and the relative humidity was held below a value of $40 \%$ by mixing the air from the chamber with make-up air that was dried using silica gel. Flow rate through the chamber was approximately $1.5 \mathrm{~L} \mathrm{~min}^{-1}$. The detector was calibrated in the laboratory before field measurement using a standard gas (3000 ppb NO; Deuste Steiniger $\mathrm{GmbH}$, Mühlhausen, Germany) which was diluted using make-up air to the range of concentrations measured in the field. Detector signal and time were recorded every five seconds with a CR800 Series data logger (Campbell Scientific, Utah, USA). NO measurements were carried out four times within the same year as the $\mathrm{N}_{2} \mathrm{O}$ measurements. All gas fluxes were calculated from the linear increase of gas concentration of the chamber air over time, multiplied by the density of air and the ratio of chamber volume to soil surface area (Köhler et al. 2009). Dilution of the NO concentration in the chamber by outside air flow through the chamber is negligible during the initial linear part of the concentration increase (Bakwin et al. 1990). Zero 
fluxes were included. Annual gas fluxes were calculated from the average of the monthly measurements expressed on a yearly basis.

\subsubsection{Soil mineral N, net N-mineralization and net nitrification}

Soil mineral $\mathrm{N}$ was determined on a composite soil sample, which consisted of four subsamples per plot. We collected these samples from the top $0.05 \mathrm{~m}$ of the surface (organic layer or mineral soil), within one meter distance of the chamber bases concomitantly to every gas sampling. In the field, part of the composite sample was added to a polyethylene bottle containing $150 \mathrm{ml}$ of 0.5 molar potassium sulfate $\left(\mathrm{K}_{2} \mathrm{SO}_{4}\right)$ solution. The remaining sample was stored in plastic bags for determination of gravimetric moisture content in the laboratory after drying for 24 hours at $105^{\circ} \mathrm{C}$. Extraction of soil mineral $\mathrm{N}$ was finished within 12 hours after field sampling. Extracts were filtered through filter papers ( $4 \mu \mathrm{m}$ nominal pore size) after one hour of agitation, and frozen immediately after a drop of chloroform was added. Samples remained frozen during transport by air to Germany, where analysis was conducted. Ammonium $\left(\mathrm{NH}_{4}{ }^{+}\right)$and nitrate $\left(\mathrm{NO}_{3}{ }^{-}\right)$concentrations of the extracts were analyzed using a continuous flow injection colorimeter (Cenco/Skalar Instruments, Breda, Netherlands) (Arnold et al. 2009).

We determined net rates of soil $\mathrm{N}$ mineralization and nitrification once a year. To determine initial $\mathrm{NH}_{4}{ }^{+}$and $\mathrm{NO}_{3}{ }^{-}$levels $\left(\mathrm{T}_{0}\right)$ four soil samples were taken per plot. A subsample of the composite plot sample was extracted in the field, as described above. The remaining subsample was put into a plastic bag, and inserted into the soil for a ten day incubation period ("buried bag method", (Hart et al. 1994)). After incubation, soil mineral $\mathrm{N}$ was extracted as described to obtain $\mathrm{T}_{1}-\mathrm{NH}_{4}{ }^{+}$and $\mathrm{NO}_{3}{ }^{-}$concentrations. Net $\mathrm{N}$ mineralization and nitrification rates were calculated from the difference in mineral $\mathrm{N}$ concentrations between $\mathrm{T}_{1}$ - and $\mathrm{T}_{0}$ (Hart et al. 1994).

\subsubsection{Statistical analyses}

Statistical analysis was carried out on the plot mean $\mathrm{N}_{2} \mathrm{O}$ and $\mathrm{NO}$ fluxes (average of four chambers). Using the $\mathrm{N}_{2} \mathrm{O}$ flux data, we first tested the spatial independence of the six plots for each topographic position, and these plots were spatially independent based on the rank version of von Neumann's ratio test (Bartels 1982). For testing the effect of elevation and topography and of continuous variables in time series data (i.e. bi-monthly measurements of $\mathrm{N}_{2} \mathrm{O}$, NO fluxes 
and soil mineral $\mathrm{N}$ ), we applied linear mixed effects models (lme) with elevation and topographic position, or the continuous variable as fixed effects, and replicate plots nested in time as random effect. We used lme for time series data because they account for temporal correlation among observations on the same experimental unit (Piepho et al. 2004). Models describing time series data were tested for autocorrelation effects by including a first order autoregressive structure and for heteroscedasticity of residual variance by including variance functions (Bliese \& Ployhart 2002). For testing the elevation and topography effects on data that were measured only once (i.e. soil characteristics, vegetation parameters and net rates of soil $\mathrm{N}$ transformation), we used two-way analysis of variance (ANOVA) with Fisher LSD test. For testing the influence of soil $\mathrm{N}$ transformation rates on $\mathrm{N}$-oxide fluxes, we used the average $\mathrm{N}$ oxide fluxes across a year for each plot. The average $\mathrm{N}_{2} \mathrm{O}$ and $\mathrm{N}_{2} \mathrm{O}+\mathrm{NO}$ fluxes were first logtransformed to correct for the non-normal distribution of the dataset. The relationships among net $\mathrm{N}$ mineralization, net nitrification, $\mathrm{N}_{2} \mathrm{O}$, $\mathrm{NO}$ and $\mathrm{N}_{2} \mathrm{O}+\mathrm{NO}$ fluxes were assessed by lme, which includes different error variances of the different spatial scales of the hierarchical design (Crawley 2009) and hence showed better fit $(\mathrm{P}<0.05)$ than the general least square model (gls). Additionally, lme models are unaffected by randomly missing data (Piepho et al. 2004). The relationships among soil characteristics, vegetation parameters and annual $\mathrm{N}$-oxide fluxes were assessed by linear regression on the means of six plots for each topographic position $(\mathrm{n}=9 ; 3$ topographic positions of 3 elevations). Linear regression was used because lme did not improve the fit of the gls model on the 9-point database $(\mathrm{P}<0.60)$. Means with \pm 1 standard error are given in the text. Effects were accepted as statistically significant if $P \leq 0.05$. Analyses were conducted using R version 2.10.1 (R Development Core Team 2009) and Statistica Service Pack 8 (StatSoft Inc., Tusla, USA).

\subsection{Results}

\subsubsection{Soil characterization}

Organic layer thickness increased with elevation and from the lower slope position to the ridge positions ( $\mathrm{P}<0.001$ for elevation and topography effect). Spatial variation in organic layer thickness was high within short distances ranging from $0.00 \mathrm{~m}$ to $0.18 \mathrm{~m}$ at the $1000 \mathrm{~m}$ site, and 
from $0.08 \mathrm{~m}$ to $0.55 \mathrm{~m}$ on the ridges of the $2000 \mathrm{~m}$ and $3000 \mathrm{~m}$ sites. Soils at lower slope positions, at midslope positions and on well drained ridge positions of the $1000 \mathrm{~m}$ and $2000 \mathrm{~m}$ sites were Eutric or Dystric Cambisols (IUSS Working Group WRB 2006) (Typic Eutropepts and Typic Dystropepts (Soil Survey Staff 1975)). Soils at the ridge position of the $1000 \mathrm{~m}$ site holding thicker organic layers were Humic Cambisols (Typic Humitropept). On most ridge positions of the $2000 \mathrm{~m}$ and $3000 \mathrm{~m}$ sites, water logging lead to the development of Histic Planosols and Stagnic Histosols (Typic Albaquults). At the $3000 \mathrm{~m}$ site, Stagnic Cambisols and Planosols (Aquic Dystropept, Typic Albaquults) dominated at the lower and midslope positions. Table 2.1 summarizes soil characteristics of the different elevations and topographic positions.

\subsubsection{Forest structure and productivity}

Both elevation and topography influenced $\mathrm{dbh}(\mathrm{P}=0.03$ for elevation effect and $\mathrm{P}<0.001$ for topography effect) and stem density $(\mathrm{P}=0.01$ for elevation effect, $\mathrm{P}=0.001$ for topography effect and the interaction), whereas tree basal area only differed with topographic position $(\mathrm{P}=0.02)$. Mean dbh decreased and stem density increased with increasing elevation. Along the topographic gradient, mean dbh decreased from the lower slope position to the ridges whereas stem density increased slightly (Table 2.2). Both elevation and topography affected annual total litter production and annual tree basal area increment $(\mathrm{P}<0.001$ for annual litter production, $\mathrm{P}<0.001$ for tree basal area increment and elevation and $\mathrm{P}<0.05$ for tree basal area increment and topography). Litter production and tree basal area increment were highest at the lower slope position of the $2000 \mathrm{~m}$ site and lowest at all positions at $3000 \mathrm{~m}$ (Table 2.2).

We found strong positive correlations between annual litter production and $\mathrm{N}$ concentrations in litterfall $\left(\mathrm{P}<0.001, \mathrm{R}^{2}=0.82\right)$ and tree basal area increment and $\mathrm{N}$ concentrations in litterfall $\left(\mathrm{P}<0.001, \mathrm{R}^{2}=0.83\right)$ (Figure $\left.2.1 \mathrm{a}, \mathrm{b}\right)$. 
Table 2.2: Forest structure, productivity and total litterfall characteristics of the topographic positions across the elevation gradient.

\begin{tabular}{|c|c|c|c|c|c|c|c|c|c|}
\hline & \multicolumn{3}{|c|}{$1000 \mathrm{~m}$} & \multicolumn{3}{|c|}{$2000 \mathrm{~m}$} & \multicolumn{3}{|c|}{$3000 \mathrm{~m}$} \\
\hline & lower slope & midslope & ridge & lower slope & midslope & ridge & lower slope & midslope & ridge \\
\hline \multicolumn{10}{|l|}{ Structure and productivity } \\
\hline Mean dbh $(\geq 10 \mathrm{~cm})^{\mathrm{b}}$ & $22.6(1.4)$ & $22.6(1.9) \mathrm{A}$ & $18.7(1.4) \mathrm{A}$ & $23.8(2.6) \mathrm{a}$ & $19.0(0.6) \mathrm{bAB}$ & $16.8(0.6) \mathrm{bAB}$ & $24.0(1.8) \mathrm{a}$ & $15.9(0.3) \mathrm{bB}$ & $14.7(0.7) \mathrm{bB}$ \\
\hline Stem density $\left(400 \mathrm{~m}^{2}\right)^{b}$ & $32.8(3.5)$ & $36.0(3.0)$ & $22.6(7.4) \mathrm{A}$ & $30.4(3.6) \mathrm{a}$ & $45.4(2.8) \mathrm{b}$ & $45.4(3.6) \mathrm{bAB}$ & $34.4(6.8)$ & $49.3(7.3)$ & $56.7(4.8) \mathrm{B}$ \\
\hline Basal area $\left(\mathrm{m}^{2} \mathrm{ha}^{-1}\right)^{\mathrm{b}}$ & $44.8(5.0)$ & $57.2(15.0)$ & $20.3(7.2)$ & $48.9(8.6)$ & $40.4(4.3)$ & $29.2(3.0)$ & $44.8(4.6)$ & $28.1(4.2)$ & $28.6(4.2)$ \\
\hline $\begin{array}{l}\text { Total litter production } \\
\left(\mathrm{Mg} \mathrm{ha}^{-1} \mathrm{yr}^{-1}\right)^{\mathrm{b}}\end{array}$ & $7.0(0.3) \mathrm{aA}$ & $8.6(0.5) \mathrm{bA}$ & $6.4(0.5) \mathrm{aA}$ & $9.5(0.5) \mathrm{aB}$ & $9.8(0.6) \mathrm{aB}$ & $7.1(0.3) \mathrm{bA}$ & $4.7(0.2) \mathrm{C}$ & $4.8(0.5) \mathrm{C}$ & $4.5(0.2) \mathrm{B}$ \\
\hline $\begin{array}{l}\text { Basal area increment } \\
\left(\mathrm{m}^{2} \mathrm{ha}^{-1} \mathrm{yr}^{-1}\right)^{\mathrm{b}}\end{array}$ & $0.6(0.1) \mathrm{AB}$ & $0.8(0.2) \mathrm{A}$ & $0.7(0.2) \mathrm{A}$ & $0.9(0.2) \mathrm{aB}$ & $0.8(0.1) \mathrm{aA}$ & $0.4(0.1) \mathrm{bAB}$ & $0.4(0.03) \mathrm{A}$ & $0.3(0.1) \mathrm{B}$ & $0.3(0.1) \mathrm{B}$ \\
\hline \multicolumn{10}{|l|}{ Total Litter } \\
\hline $\mathrm{N}\left(\mathrm{mg} \mathrm{g}^{-1}\right)^{\mathrm{b}}$ & $16.5(0.4) \mathrm{A}$ & $15.9(0.6) \mathrm{A}$ & $15.3(1.2) \mathrm{A}$ & $21.1(1.7) \mathrm{aB}$ & $19.3(1.2) \mathrm{aB}$ & $13.8(0.7) \mathrm{bA}$ & $12.0(0.4) \mathrm{aC}$ & $9.9(0.8) \mathrm{aC}$ & $7.1(0.3) \mathrm{bB}$ \\
\hline $\mathrm{N}\left(\mathrm{g} \mathrm{m}^{-2}\right)^{\mathrm{b}}$ & $11.6(0.8) \mathrm{A}$ & $13.7(0.8) \mathrm{A}$ & $10.1(1.5) \mathrm{A}$ & $19.7(1.4) \mathrm{aB}$ & $19.2(2.2) \mathrm{aB}$ & $9.7(0.6) \mathrm{bA}$ & $5.7(0.3) \mathrm{C}$ & $4.7(0.5) \mathrm{C}$ & $3.1(0.2) \mathrm{B}$ \\
\hline $\mathrm{C}: \mathrm{N}^{\mathrm{b}}$ & $31.7(1.0) \mathrm{A}$ & $32.6(1.4) \mathrm{A}$ & 35.8 (2.9)A & $24.8(2.4) \mathrm{aA}$ & $27.0(2.2) \mathrm{aA}$ & $39.6(2.2) \mathrm{bA}$ & $43.8(1.8) \mathrm{aB}$ & $55.5(5.0) \mathrm{bB}$ & $77.9(3.1) \mathrm{cB}$ \\
\hline$\delta{ }^{15} \mathrm{~N}(\% \mathrm{o})^{\mathrm{b}}$ & $1.6(0.2) \mathrm{A}$ & $1.1(0.4) \mathrm{A}$ & $1.2(0.4) \mathrm{A}$ & $3.4(0.4) \mathrm{aB}$ & $1.8(0.3) \mathrm{bA}$ & - $1.3(0.4) \mathrm{cB}$ & $0.3(0.2) \mathrm{aC}$ & $-1.4(0.7) \mathrm{bB}$ & $-2.6(0.5) b C$ \\
\hline $\mathrm{P}\left(\mathrm{mg}(\mathrm{P}) \mathrm{g}^{-1}\right)^{\mathrm{b}}$ & $0.8(0.1) \mathrm{A}$ & $0.8(0.1) \mathrm{A}$ & $0.7(0.1) \mathrm{A}$ & $1.3(0.1) \mathrm{aB}$ & $1.2(0.2) \mathrm{aB}$ & $0.6(0.0) \mathrm{bAB}$ & $0.6(0.0) \mathrm{A}$ & $0.4(0.0) \mathrm{C}$ & $0.3(0.1) \mathrm{B}$ \\
\hline $\mathrm{P}\left(\mathrm{g} \mathrm{m}^{-2}\right)^{\mathrm{b}}$ & $0.6(0.1) \mathrm{aA}$ & $0.7(0.1) \mathrm{aA}$ & $0.5(0.1) \mathrm{bA}$ & $1.2(0.1) \mathrm{aB}$ & $1.2(0.3) \mathrm{aB}$ & $0.4(0.04) \mathrm{bA}$ & $0.3(0.02) \mathrm{aC}$ & $0.2(0.02) \mathrm{bC}$ & $0.2(0.03) \mathrm{bB}$ \\
\hline
\end{tabular}

${ }^{\mathrm{b}}$ Means $( \pm \mathrm{SE}, \mathrm{n}=6)$ within rows followed by different letter indicate significant differences among topographic positions at each elevation (small letters) and differences among elevations at each topographic position (capital letters) (one-way ANOVA with Fisher's LSD test at $P \leq 0.05$ ). 
Furthermore, several indices of $\mathrm{N}$ availability, e.g. C:N ratio and $\delta{ }^{15} \mathrm{~N}$ signatures of litterfall displayed strong correlations with litter production $\left(\mathrm{P}<0.01, \mathrm{R}^{2}=0.62\right.$ for $\mathrm{C}: \mathrm{N}$ ratio (Figure 2.1 a) and $\mathrm{P}=0.02, \mathrm{R}^{2}=0.54$ for $\delta^{15} \mathrm{~N}$ signatures of litterfall) and tree basal area increment $\left(\mathrm{P}<0.01, \mathrm{R}^{2}=0.70\right.$ for $\mathrm{C}: \mathrm{N}$ ratio (Figure $2.2 \mathrm{~b}$ ) and $\mathrm{P}<0.001, \mathrm{R}^{2}=0.81$ for $\delta^{15} \mathrm{~N}$ signatures of litterfall).
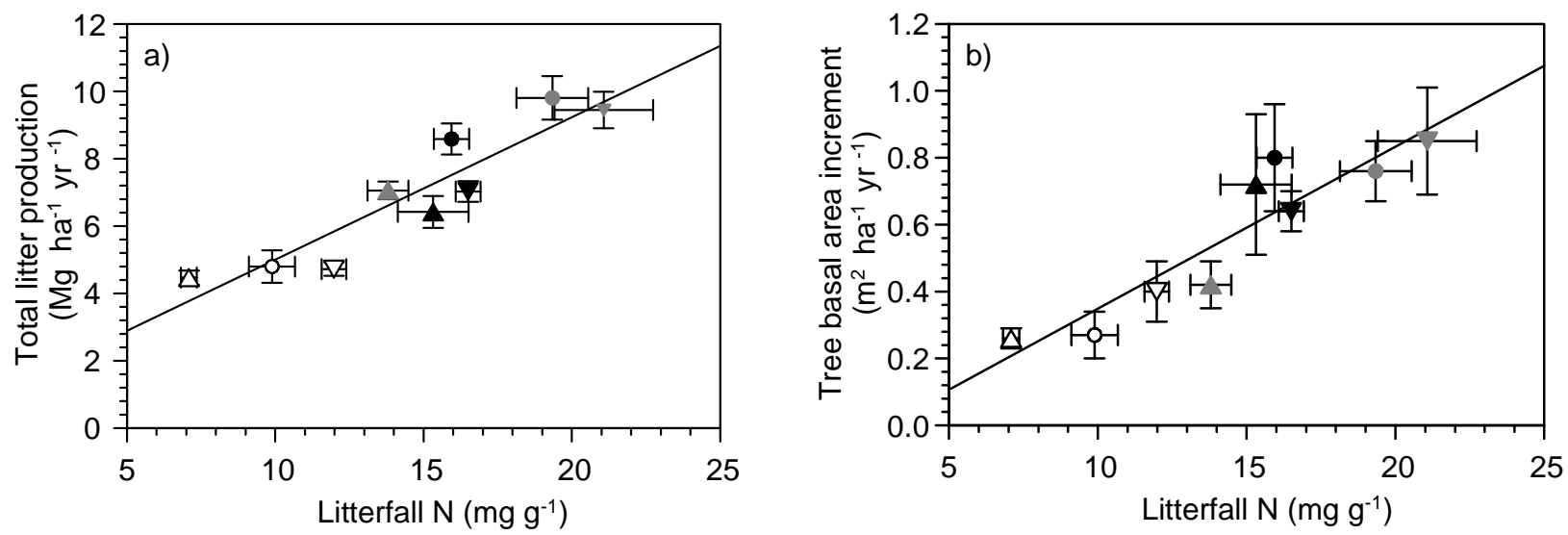

Figure 2.1: Linear regression of litterfall $\mathrm{N}$ and a) total litter production $(\mathrm{Y}=0.77+0.42 * \mathrm{X}$, $\left.P<0.001, R^{2}=0.82\right)$, b) tree basal area increment $\left(Y=-0.14+0.05 * X, P<0.001, R^{2}=0.83\right)$ of the topographic positions across the elevation gradient. Symbols used for data: full black, $1000 \mathrm{~m}$; full grey, $2000 \mathrm{~m}$; open, $3000 \mathrm{~m}$; $\nabla$ Lower slope, $\bullet$ Midslope, $\triangle$ Ridge.
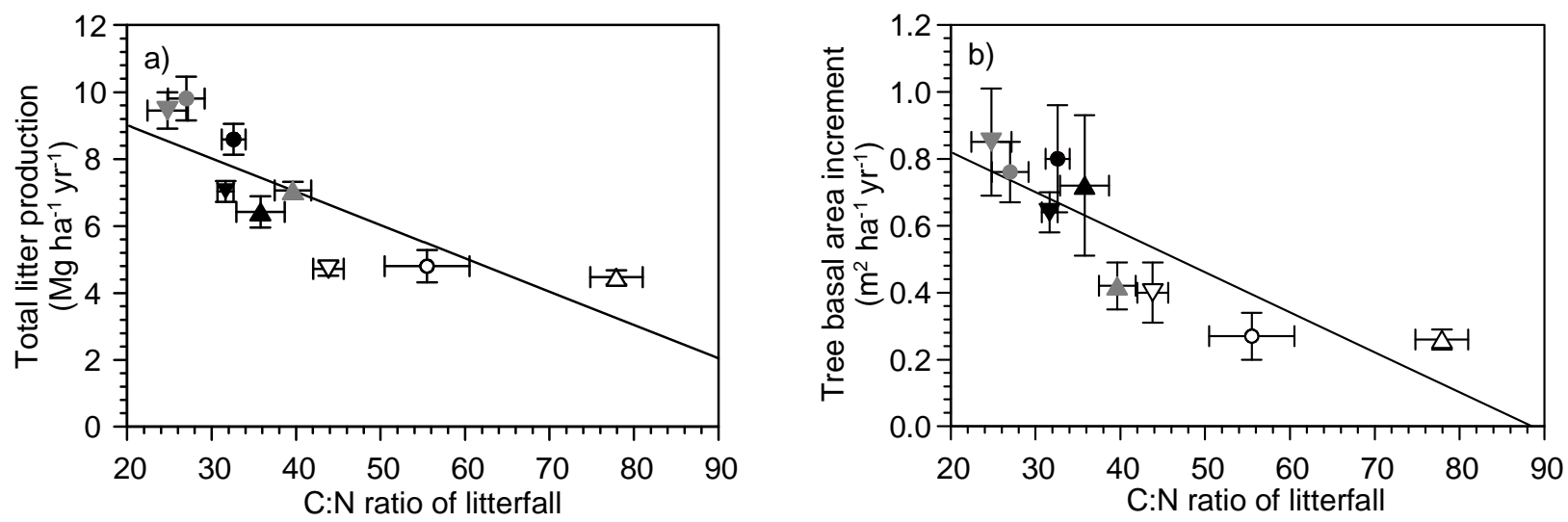

Figure 2.2: Linear regression of $\mathrm{C}: \mathrm{N}$ ratio of litterfall and a) total litter production $(\mathrm{Y}=11.0-0.09$ $\left.* \mathrm{X}, P<0.01, R^{2}=0.62\right)$, b) tree basal area increment $\left(\mathrm{Y}=1.06-0.01 * \mathrm{X}, P<0.01, R^{2}=0.70\right)$ of the topographic positions across the elevation gradient. Symbols used for data: full black, $1000 \mathrm{~m}$; full grey, $2000 \mathrm{~m}$; open, $3000 \mathrm{~m}$; $\nabla$ Lower slope, $\bullet$ Midslope, $\triangle$ Ridge. 


\subsubsection{N-oxide fluxes and soil moisture}

Nitrous oxide fluxes did not display clear seasonality at any of the sites, probably because of the lack of a pronounced dry season. Elevation as well as topography influenced $\mathrm{N}_{2} \mathrm{O}$ fluxes ( $\mathrm{P}<0.001$ for elevation and topography effect) and NO fluxes $(\mathrm{P}<0.001$ for elevation and $\mathrm{P}=0.02$ for topography). $\mathrm{N}_{2} \mathrm{O}$ and $\mathrm{NO}$ fluxes were highest at the lower slope positions of the $2000 \mathrm{~m}$ site and lowest at the $3000 \mathrm{~m}$ site (Table 2.3). Topography affected $\mathrm{N}_{2} \mathrm{O}$ fluxes at $2000 \mathrm{~m}(\mathrm{P}<0.001)$ and NO at $3000 \mathrm{~m}(\mathrm{P}=0.02)$. In both cases gas fluxes decreased toward the ridge positions. Ridge positions at the $3000 \mathrm{~m}$ site showed negative annual $\mathrm{N}_{2} \mathrm{O}$ fluxes and zero NO fluxes, while soils at the lower slope and midslope positions emitted $\mathrm{N}_{2} \mathrm{O}$ and NO.

At all elevations $\mathrm{N}_{2} \mathrm{O}$ fluxes exceeded $\mathrm{NO}$ fluxes. We did not calculate a $\mathrm{N}_{2} \mathrm{O} / \mathrm{NO}$ ratio because negative $\mathrm{N}_{2} \mathrm{O}$ fluxes occurred and $\mathrm{NO}$ fluxes were close to zero. Gravimetric moisture content increased with elevation and from the lower slope positions to the ridges $(\mathrm{P}<0.001$ for the influence of elevation and topography effect). Throughout the sites gravimetric moisture content did not correlate with $\mathrm{N}_{2} \mathrm{O}+\mathrm{NO}$ fluxes $\left(\mathrm{P}=0.06, \mathrm{R}^{2}=0.33\right)$ or the ratio of $\mathrm{N}_{2} \mathrm{O} / \mathrm{N}$ oxide emissions $\left(\mathrm{P}=0.08, \mathrm{R}^{2}=0.29\right)$. Excluding the elevation effect, gravimetric moisture content did not influence $\mathrm{N}_{2} \mathrm{O}+\mathrm{NO}$ fluxes within either of the sites. We did not use WFPS as index for soil moisture content, because a comparison of calculated WFPS of organic layers and mineral soil was not possible. 


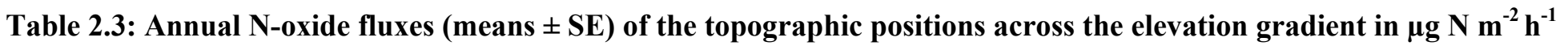

\begin{tabular}{|c|c|c|c|c|c|c|c|c|c|}
\hline & \multicolumn{3}{|c|}{$1000 \mathrm{~m}$} & \multicolumn{3}{|c|}{$2000 \mathrm{~m}$} & \multicolumn{3}{|c|}{$3000 \mathrm{~m}$} \\
\hline & lower slope & midslope & ridge & lower slope & midslope & ridge & lower slope & midslope & ridge \\
\hline $\mathrm{N}_{2} \mathrm{O}^{\mathrm{b}}$ & 1.90 (1.38)A & $3.53(1.13)$ & $4.14(1.56)$ & $14.54(2.13) \mathrm{aB}$ & $3.68(1.46) \mathrm{b}$ & $1.15(1.48) \mathrm{b}$ & $1.63(1.14) \mathrm{A}$ & $1.34(1.43)$ & $-0.53(0.94)$ \\
\hline $\mathrm{NO}^{\mathrm{b}}$ & $0.75(0.10)$ & $1.11(0.32) \mathrm{A}$ & $0.72(0.31) \mathrm{A}$ & $1.11(0.36)$ & $1.13(0.33) \mathrm{A}$ & $0.14(0.08) \mathrm{B}$ & $0.19(0.06) \mathrm{a}$ & $0.06(0.04) \mathrm{abB}$ & $-0.02(0.03) b B$ \\
\hline $\mathrm{N}_{2} \mathrm{O}+\mathrm{NO}^{\mathrm{b}}$ & $2.66(1.32) \mathrm{A}$ & $4.63(1.36)$ & 4.85 (1.77)A & $15.66(2.27) \mathrm{aB}$ & $4.82(1.50) \mathrm{b}$ & $1.28(1.51) \mathrm{cB}$ & $1.82(1.09) \mathrm{C}$ & $1.41(1.46)$ & $-0.54(0.92) \mathrm{C}$ \\
\hline
\end{tabular}

${ }^{\mathrm{b}}$ Means $( \pm \mathrm{SE}, \mathrm{n}=6$ ) within rows followed by different letter indicate significant differences among topographic positions at each elevation (small letters) and differences among elevations at each topographic position (capital letters) (Linear mixed effects models with Fisher's LSD test at $P \leq 0.05$ ).

Table 2.4: Average soil mineral $\mathrm{N}$, net $\mathrm{N}$ mineralization and net nitrification rates (means $\pm \mathrm{SE}$ ) of the topographic positions across the elevation gradient.

\begin{tabular}{|c|c|c|c|c|c|c|c|c|c|c|}
\hline & \multirow[b]{2}{*}{ Unit } & \multicolumn{3}{|c|}{$1000 \mathrm{~m}$} & \multicolumn{3}{|c|}{$2000 \mathrm{~m}$} & \multicolumn{3}{|c|}{$3000 \mathrm{~m}$} \\
\hline & & lower slope & midslope & ridge & lower slope & midslope & ridge & lower slope & midslope & ridge \\
\hline Extractable $\mathrm{NH}_{4}^{+}{ }^{\mathrm{b}}$ & $\operatorname{kg}(\mathrm{N}) \mathrm{ha}^{-1}$ & $2.2(0.4) \mathrm{A}$ & $1.8(0.5) \mathrm{A}$ & $1.5(0.5)$ & $0.8(0.2) \mathrm{B}$ & $0.9(0.3) \mathrm{AB}$ & $0.9(0.2)$ & $0.6(0.1) \mathrm{B}$ & $0.7(0.1) \mathrm{B}$ & $0.8(0.1)$ \\
\hline Extractable $\mathrm{NO}_{3}{ }^{-}$ & $\mathrm{kg}(\mathrm{N}) \mathrm{ha}^{-1}$ & $0.4(0.1) \mathrm{A}$ & $0.4(0.1) \mathrm{A}$ & $0.6(0.3) \mathrm{A}$ & $0.4(0.1) \mathrm{aA}$ & $0.3(0.1) \mathrm{aA}$ & $0.04(0.02) \mathrm{bB}$ & $0.0 \mathrm{~B}$ & $0.02(0.01) \mathrm{B}$ & $0.03(0.01) \mathrm{B}$ \\
\hline Net $\mathrm{N}$ mineralisation $^{\mathrm{c}}$ & $\mathrm{kg}(\mathrm{N}) \mathrm{ha}^{-1} 10 \mathrm{~d}^{-1}$ & $3.6(1.2) \mathrm{A}$ & $3.1(0.9)$ & $0.8(0.6) \mathrm{AB}$ & $1.7(0.4) \mathrm{B}$ & $1.4(0.7)$ & $1.5(0.3) \mathrm{AB}$ & $0.2(0.2) \mathrm{B}$ & $0.6(0.4)$ & $-0.4(0.3) \mathrm{B}$ \\
\hline Net nitrification $^{c}$ & $\mathrm{~kg}(\mathrm{~N})$ ha $^{-1} 10 \mathrm{~d}^{-1}$ & $3.9(1.5) \mathrm{A}$ & $1.7(1.3)$ & $0.4(0.6)$ & $0.8(0.5) \mathrm{B}$ & $1.8(0.6)$ & $0.02(0.3)$ & $0.0 \mathrm{~B}$ & $0.04(0.04)$ & 0.0 \\
\hline
\end{tabular}

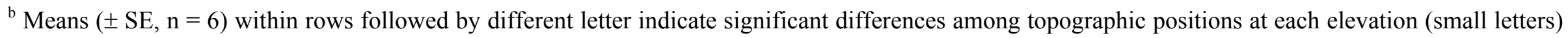
and differences among elevations at each topographic position (capital letters) (Linear mixed effects models with Fisher's LSD test at $P<0.05$ ).

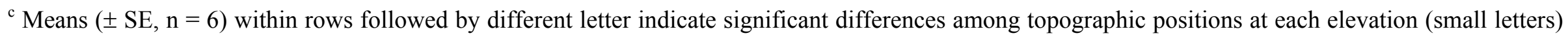
and differences among elevations at each topographic position (capital letters) (one-way ANOVA with Fisher's LSD test at $P \leq 0.05$ ) 


\subsubsection{Indices of $\mathrm{N}$ availability and their control on $\mathrm{N}$-oxide fluxes}

Elevation affected mineral $\mathrm{N}$ content of the topsoil $\left(\mathrm{P}<0.001\right.$ for $\mathrm{NH}_{4}{ }^{+}$and $\left.\mathrm{NO}_{3}{ }^{-}\right)$. We found declining mineral $\mathrm{N}$ concentrations with increasing elevation. Topography did not have significant influence on mineral $\mathrm{N}$ content of the soil, with the exception of the $2000 \mathrm{~m}$ site $(\mathrm{P}<0.001)$. At all sites, extractable $\mathrm{NH}_{4}{ }^{+}$was the dominant form of mineral $\mathrm{N}$ and in $60 \%$ of the extracts $\mathrm{NO}_{3}{ }^{-}$was below detection limit. At the $3000 \mathrm{~m}$ site, $\mathrm{NO}_{3}{ }^{-}$was below detection limit in $90 \%$ of the extracts. Elevation had stronger influence on net $\mathrm{N}$ mineralization rate $(\mathrm{P}<0.001)$ and net nitrification rate $(\mathrm{P}=0.01)$ than topography $(\mathrm{P}=0.05$ for net $\mathrm{N}$ mineralization and net nitrification). Both net $\mathrm{N}$ mineralization and net nitrification rates were declining with increasing elevation, whereas there was no clear trend along the topographic gradient of either elevation (Table 2.4). Throughout all sites and within each site, bi-monthly measured mineral $\mathrm{N}$ contents did not significantly influence $\mathrm{N}_{2} \mathrm{O}$ and $\mathrm{NO}$ fluxes. Net $\mathrm{N}$ mineralization and net nitrification rates did not affect annual means of the $\mathrm{N}_{2} \mathrm{O}$, $\mathrm{NO}$ or $\mathrm{N}_{2} \mathrm{O}+\mathrm{NO}$ fluxes.

Nitrogen cycling indices such as $\mathrm{C}: \mathrm{N}$ ratio and $\delta{ }^{15} \mathrm{~N}$ signatures of litterfall, organic layer and upper mineral soil were affected by elevation as well as topography ( $\mathrm{P}<0.001$ for elevation and topography effect on $\mathrm{C}: \mathrm{N}$ ratio and $\delta{ }^{15} \mathrm{~N}$ signature of all three substrates). C:N ratios of litterfall, organic layer and upper mineral soil increased and $\delta{ }^{15} \mathrm{~N}$ signatures of litterfall and organic layer decreased along the topographic gradient form the lower slope position to the ridges at all sites (Table 2.2). Differences in these $\mathrm{N}$ cycling indices between topographic positions and between elevations were less pronounced in the mineral soil, indicating that $\delta^{15} \mathrm{~N}$ enrichment and $\mathrm{N}$ cycling were restricted to the organic layer. The lower slope positions at the $2000 \mathrm{~m}$ site showed lowest $\mathrm{C}: \mathrm{N}$ ratios and highest $\delta{ }^{15} \mathrm{~N}$ signatures of litterfall and organic layer. Negative $\delta{ }^{15} \mathrm{~N}$ signatures of litterfall occurred at the ridges of the $2000 \mathrm{~m}$ site and at midslope and ridge positions of the $3000 \mathrm{~m}$ site. Throughout the elevation gradient, we found strong correlations of $\mathrm{N}_{2} \mathrm{O}+\mathrm{NO}$ fluxes with $\mathrm{C}: \mathrm{N}$ ratio and $\delta{ }^{15} \mathrm{~N}$ signatures of litterfall $\left(\mathrm{P}=0.02, \mathrm{R}^{2}=0.54\right.$ for $\mathrm{C}: \mathrm{N}$ ratio, and $\mathrm{P}<0.001, \mathrm{R}^{2}=0.83$ for $\delta{ }^{15} \mathrm{~N}$ signatures) (Figure $2.3 \mathrm{a}, \mathrm{b}$ ) and of the organic layer $\left(\mathrm{P}=0.01, \mathrm{R}^{2}=0.57\right.$ for $\mathrm{C}: \mathrm{N}$ ratio, and $\mathrm{P}=0.01, \mathrm{R}^{2}=0.58$ for $\delta^{15} \mathrm{~N}$ signatures $)$. Ratios of $\mathrm{C}: \mathrm{N}$ and $\delta{ }^{15} \mathrm{~N}$ signatures of the mineral soil did not correlate with $\mathrm{N}_{2} \mathrm{O}+\mathrm{NO}$ fluxes. Finally, we found strong correlations of $\mathrm{N}_{2} \mathrm{O}+\mathrm{NO}$ flux with proxies of forest productivity like annual litter production $\left(\mathrm{P}=0.02, \mathrm{R}^{2}=0.53\right)$ and tree basal area increment $\left(\mathrm{P}<0.01, \mathrm{R}^{2}=0.72\right)$ (Figure 2.3 
c, d). Both proxies also showed strong correlations with NO fluxes $\left(P<0.001, \mathrm{R}^{2}=0.77\right.$ for annual litter production, and $\mathrm{P}=0.01, \mathrm{R}^{2}=0.65$ for tree basal area increment) and with $\mathrm{N}_{2} \mathrm{O}$ fluxes $\left(\mathrm{P}<0.05, \mathrm{R}^{2}=0.44\right.$ for annual litter production and $\mathrm{P}=0.05, \mathrm{R}^{2}=0.38$ for tree basal area increment).
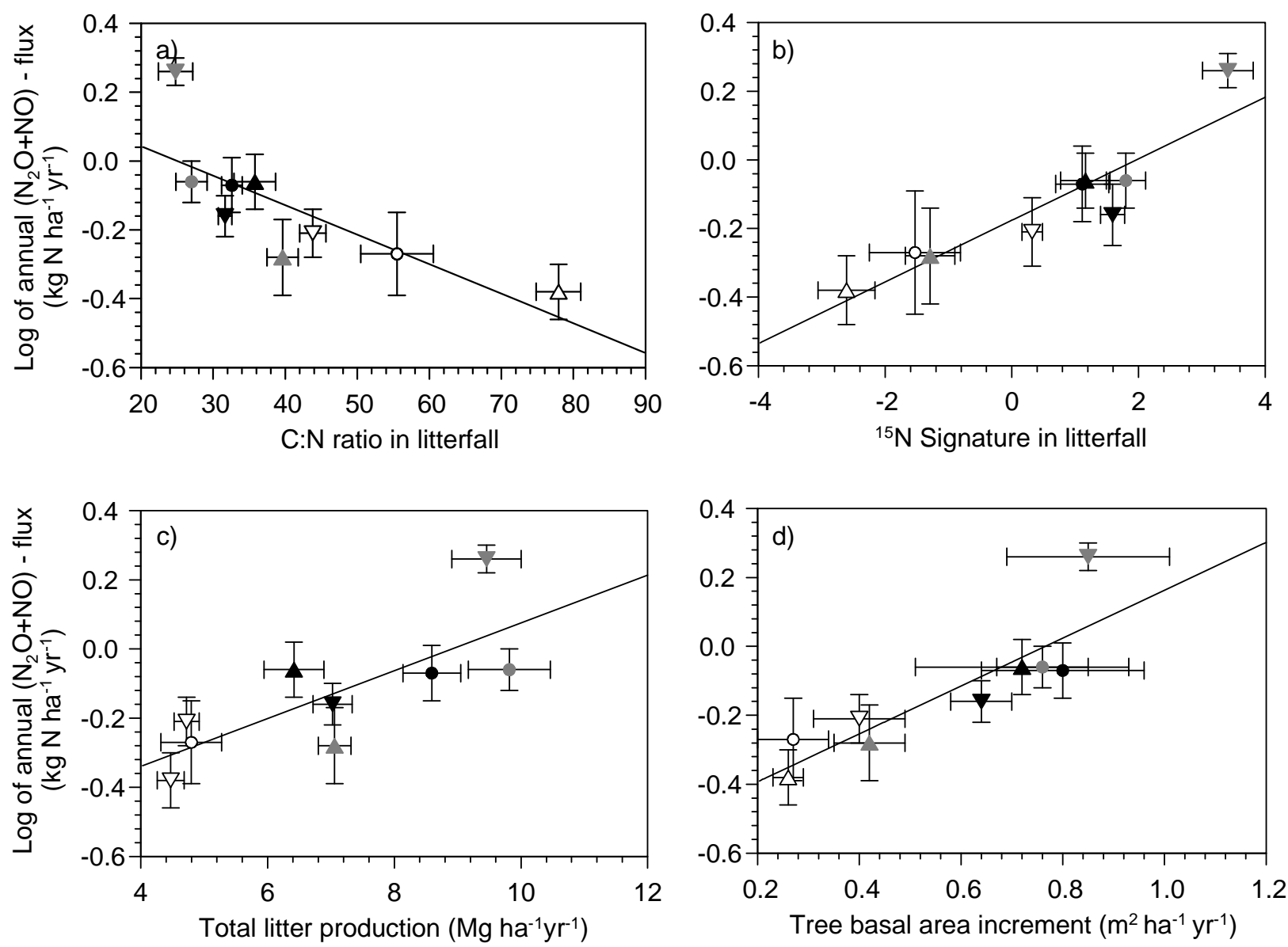

Figure 2.3: Linear regression of log-transformed annual $\mathrm{N}_{2} \mathrm{O}+\mathrm{NO}$ fluxes and a) $\mathrm{C}: \mathrm{N}$ ratio of total litterfall $\left.\left(\mathrm{Y}=0.22-0.01 * \mathrm{X}, P=\mathbf{0 . 0 2}, \boldsymbol{R}^{2}=\mathbf{0 . 5 4}\right), \mathrm{b}\right) \delta^{15} \mathrm{~N}$ of litterfall $(\mathrm{Y}=\mathbf{- 0 . 1 8}+\mathbf{0 . 0 9} * \mathrm{X}$, $\left.P<0.001, R^{2}=0.83\right)$, c) total litter production $\left(Y=-0.62+0.07 * X, P=0.02, R^{2}=0.53\right)$, and d) tree basal area increment $\left(\mathrm{Y}=\mathbf{- 0 . 5 3}+\mathbf{0 . 6 9} * \mathrm{X}, P<0.01, R^{2}=0.72\right)$ of the topographic positions across the elevation gradient. Symbols used for data: full black, 1000 m; full grey, 2000 m; open, 3000 m; $\nabla$ Lower slope, $\bullet$ Midslope, $\triangle$ Ridge. 


\subsection{Discussion}

\subsubsection{Organic layers and nitrogen availability along elevation and topographic gradients}

The increasing thickness of organic layers with increasing elevation and from lower slopes to ridge positions have been reported for other tropical montane forests (Arnold et al. 2009; Grubb 1977; Purbopuspito et al. 2006). Thick organic layers imply that considerable amounts of nitrogen are stored and not actively cycling in the ecosystem. Grubb (1977) suggested that this was one of the reasons for reduced $\mathrm{N}$-availability in tropical montane forests. Thick organic layers develop if decomposition is slower than organic matter (above- and belowground litter) input. While the lower temperatures (causing slower decomposition, Table 2.1) together with an increase in root/aboveground biomass ratio (Leuschner et al. 2007) probably explains the increasing thickness of organic layers with elevation, water logging has been suggested to contribute to the slow decomposition of organic matter on the relatively flat ridge positions at $2000 \mathrm{~m}$ and $3000 \mathrm{~m}$ (Leuschner et al. 2007; Wilcke et al. 2002). Additionally, the feedback of tree vegetation to the environmental conditions at the exposed ridges in combination with the low nutrient availability probably affected species composition (Homeier et al. 2010) and reduced litter quality at the ridge positions (as shown by the high $\mathrm{C}: \mathrm{N}$ ratios, Table 2.2) further reduced decomposition rates. In summary, we found evidence that a combination of climatic and hydrological conditions and the resulting plant feedbacks contributed to the observed large differences in organic layer thickness of these tropical montane forest soils.

Several lines of evidence suggest that parallel to the increasing thickness of organic layers, $\mathrm{N}$ availability decreased with elevation and from lower slope to ridge positions. First, net Nmineralization and net nitrification rates decreased with increasing elevation. Similar findings were reported in studies comparing tropical forests at different elevations (Arnold et al. 2009; Grubb 1977; Köhler et al. 2009; Marrs et al. 1988; Silver et al. 1994). Second, the C:N ratios of litterfall (Table 2.2) and of soil organic layers (Table 2.1) suggest decreasing $\mathrm{N}$ availability with elevation and from the lower slope to the ridge position. In ecosystems with low $\mathrm{N}$ availability nutrient use efficiency is high (Vitousek 1982) leading to high $\mathrm{C}: \mathrm{N}$ ratios in plant tissue. In our study, this was evident at the ridge positions at the $2000 \mathrm{~m}$ site and all positions at the $3000 \mathrm{~m}$

site. Third, the decreasing $\delta{ }^{15} \mathrm{~N}$ signatures of litterfall and of the organic layer with increasing 
elevation and from lower slope positions to the ridges imply decreasing $\mathrm{N}$ availability. Signatures of $\delta{ }^{15} \mathrm{~N}$ reflect the long-term behavior of the soil $\mathrm{N}$ cycle of an ecosystem. Forest ecosystems with high $\mathrm{N}$ availability have high $\delta{ }^{15} \mathrm{~N}$ signatures because isotopic light $\mathrm{N}$ is preferentially lost from the ecosystem owing to fractionation during nitrification and denitrification, leaving ${ }^{15} \mathrm{~N}$ enriched $\mathrm{N}$ behind (Robinson 2001). Sotta et al. (2008) showed this in the $\delta{ }^{15} \mathrm{~N}$ signatures of litterfall and soil, which reflected the magnitude of soil $\mathrm{N}$ cycling rates of a lowland forest in the Brazilian Amazon. The $\delta{ }^{15} \mathrm{~N}$ signatures of litterfall also correlated with nitrogen losses from tropical forests in Indonesia (Purbopuspito et al. 2006) and Panama (Corre et al. 2010). On volcanic ash soils in Hawaii, however, $\delta^{15} \mathrm{~N}$ signatures in mineral soil and leaves depended on soil development stage rather than elevation (Vitousek et al. 1989). At our study sites, slope processes rejuvenate soils at all elevations, leading to relatively young soils throughout the study sites. Our elevation gradient thus does not reflect a chronosequence in terms of soil age. Consequently, nitrogen availability was not controlled by soil development. Finally, at the $1000 \mathrm{~m}$ site most of the mineralized $\mathrm{N}$ was also nitrified, whereas at $3000 \mathrm{~m}$ net nitrification was only $3 \%$ of net $\mathrm{N}$ mineralization. This suggests that microbial $\mathrm{N}$ immobilization increased along the elevation gradient implying increasing competition of nitrogen with increasing elevation (Arnold et al. 2009).

We can summarize that in these tropical montane forests organic layer thickness increased and $\mathrm{N}$ availability decreased with increasing elevation and from lower slope to ridge positions. At the $2000 \mathrm{~m}$ site, the lower slope and midslope positions displayed a higher $\mathrm{N}$ availability than the $1000 \mathrm{~m}$ site, which indicates that at this elevation the 'topography effect' was more pronounced than the 'elevation effect'. These results suggest that in these tropical montane forests thickness of organic layers and $\mathrm{N}$ availability can be predicted based on elevation and topographic position (Pennock \& Corre 2001).

\subsection{2 $\mathrm{N}$ availability and forest productivity}

Annual litter production at our study sites was within the range reported for tropical montane forest sites (Röderstein et al. 2005; Vitousek 1984; Vitousek et al. 1995), whereas values for the lower and midslope positions of the $2000 \mathrm{~m}$ site were on the high end compared to other studies (Hall et al. 2004; Purbopuspito et al. 2006; Röderstein et al. 2005; Veneklaas 1991). Our finding 
that forest productivity (expressed as annual litter production and tree basal area increment) decreased with increasing elevation and from the lower slope positions to the ridge positions reflects the results from earlier studies carried out in tropical montane forests (Grubb 1977; Homeier et al. 2010; Moser et al. 2007; Takyu et al. 2002; Tanner et al. 1998) and mirrors the systematic change in $\mathrm{N}$ availability. However, litterfall does not always change systematically with elevation in tropical mountains as shown by Clark et al. (2001) and Röderstein et al. (2005). Stem growth and basal area increment of tropical forest trees is determined by site conditions and the succession stage of the forest stand and it has been shown to vary strongly across tropical forest landscapes (Clark et al. 2001; Malhi et al. 2004). In contrast to findings from tropical forests in Brazil, where forest productivity decreased with soil development (Anderson et al. 2009; Malhi et al. 2004), soil age did not control productivity along our elevation gradient because we did not have systematic differences in soil development. Since we studied only oldgrowth forests, our plots contain primarily late-successional, slow-growing tree species and our basal area increment rates between 0.3 and $0.9 \mathrm{~m}^{2} \mathrm{ha}^{-1} \mathrm{yr}^{-1}$ are probably below the forest stands' average because we omitted early-successional stands which contain many pioneer species. However, our values are in the range of basal area increment rates reported from neotropical forests $\left(0.3-1.1 \mathrm{~m}^{2} \mathrm{ha}^{-1} \mathrm{yr}^{-1}\right.$ (Malhi et al. 2004)), with basal area growth rates of the lower and midslope positions of the $2000 \mathrm{~m}$ site being in the upper range, indicating the high productivity of these sites.

The correlations of forest productivity with proxies of $\mathrm{N}$ availability $(\mathrm{C}: \mathrm{N}$ ratio and $\delta{ }^{15} \mathrm{~N}$ signature of litterfall) suggest that forest productivity depended on $\mathrm{N}$ availability and that the forest sites we studied were (co-) limited by nitrogen. This is in line with the results from other studies, that found a positive correlation between tree growth and $\mathrm{N}$ availability (Cavelier et al. 2000; Homeier et al. 2010; Tanner et al. 1992) in neotropical montane forests. Also nitrogen addition experiments in tropical montane forests have shown significant increases in forest productivity following nitrogen additions which indicates $\mathrm{N}$ limitation (e.g. Adamek et al., (2009)). This was also the case in a nutrient addition experiment conducted close to our sites (Homeier et al., unpublished data). 


\subsubsection{N-oxide fluxes and $\mathrm{N}$ availability}

The $\mathrm{N}_{2} \mathrm{O}$ fluxes in these tropical montane forests were lower than most studies published from tropical lowland forests (Köhler et al. 2009; Werner et al. 2007). They fit within the range of values reported for tropical montane forests, with a study from Hawaii reporting lower fluxes (Matson \& Vitousek 1987; Riley \& Vitousek 1995) and studies from Panama (Köhler et al. 2009), Indonesia (Purbopuspito et al. 2006), Australia (Breuer et al. 2000) and Hawaii (Holtgrieve et al. 2006) reporting slightly higher $\mathrm{N}_{2} \mathrm{O}$ fluxes. The lower slope position at the $2000 \mathrm{~m}$ site was the only site that displayed much higher $\mathrm{N}_{2} \mathrm{O}$ fluxes than expected. Only few studies measured NO fluxes from tropical montane forests. Their results are in the same range as our measurements at $1000 \mathrm{~m}$ and $2000 \mathrm{~m}$ elevation (Köhler et al. 2009; Purbopuspito et al. 2006); but higher than our fluxes measured above 2000 m (Purbopuspito et al. 2006).

The $\mathrm{N}_{2} \mathrm{O}+\mathrm{NO}$ fluxes largely followed the gradients that we detected for $\mathrm{N}$ availability. This was clear for the declining $\mathrm{N}_{2} \mathrm{O}+\mathrm{NO}$ fluxes with elevation, but was not significant for topographic position at all elevations, due to the high spatial variability between sites (Table 2.3). Other studies have also reported lower $\mathrm{N}_{2} \mathrm{O}$ emissions and even $\mathrm{N}_{2} \mathrm{O}$ uptake at ridge positions compared to lower slope positions (Bowden et al. 1992; Corre et al. 1996; Reiners et al. 1998). For the different proxies for $\mathrm{N}$ availability that we tested, we did not find good correlations of $\mathrm{N}$-oxide fluxes with mineral $\mathrm{N}$, net $\mathrm{N}$ mineralization and net nitrification rates as have been reported in a range of studies carried out in tropical ecosystems (Erickson et al. 2001; Holtgrieve et al. 2006; Keller \& Reiners 1994; Matson \& Vitousek 1987; Riley \& Vitousek 1995). The reason is probably the high temporal and spatial variability of mineral $\mathrm{N}$ pools and net $\mathrm{N}$ mineralization and net nitrification rates (Veldkamp et al. 1999). We did however find strong correlations with more integrative indices of the long-term $\mathrm{N}$ cycle: $\mathrm{C}: \mathrm{N}$ ratio and $\delta{ }^{15} \mathrm{~N}$ signature of litterfall which has also been shown in other studies conducted in tropical ecosystems (Davidson et al. 2000; Erickson et al. 2001; Purbopuspito et al. 2006). The combined results of very low $\mathrm{N}$-Oxide emissions, low $\mathrm{N}$ turnover rates and negative $\delta^{15} \mathrm{~N}$ signatures of plant litter at high elevations and on the ridges illustrate that slow $\mathrm{N}$ mineralization combined with $\mathrm{N}$ uptake by the vegetation probably resulted in marginal nitrification rates (often not detectable at our sites) and consequently minimal N-Oxide fluxes (Handley et al. 1999). Furthermore, at these wet sites any soil nitrate that may have been produced was probably 
completely consumed by denitrification, thus reducing the expression of the isotope effect at the ecosystem scale (Houlton et al. 2006). In contrast, at the slightly drier and warmer sites, higher $\delta^{15} \mathrm{~N}$ signatures illustrate the strong discriminating effect of nitrification and denitrification caused by the high $\mathrm{N}$-oxide emissions (Houlton \& Bai 2009). A test of C:N ratios and $\delta{ }^{15} \mathrm{~N}$ signatures of organic layers and mineral soil as proxies for $\mathrm{N}_{2} \mathrm{O}+\mathrm{NO}$ fluxes, resulted in weaker correlations and supported similar findings of Purbopuspito et al. (2006) in montane forests of Indonesia.

\subsubsection{Nitrogen availability as a link between forest productivity and N-oxide fluxes}

The close correlation of indices of $\mathrm{N}$ availability with forest productivity and N-oxide fluxes we interpret as evidence that nitrogen availability controls both forest productivity and N-oxide fluxes in the studied tropical montane forests. The good correlations of indices of forest productivity with $\mathrm{N}$ oxides fluxes in our study (Figure $2.3 \mathrm{c}, \mathrm{d}$ ) suggest that data on forest productivity have the potential to be used as predictors of $\mathrm{N}_{2} \mathrm{O}+\mathrm{NO}$ fluxes. However, it is important to note that we can only expect close correlations between indices of forest productivity and $\mathrm{N}$ oxide fluxes in ecosystems that are (co)-limited in nitrogen. If nitrogen is not the limiting nutrient, forest productivity does not increase with $\mathrm{N}$ availability while $\mathrm{N}$-oxide fluxes do. Thus, in ecosystems that are not N-limited (e.g. many tropical lowland forests), we cannot expect that forest productivity correlates with $\mathrm{N}$ availability and $\mathrm{N}$-oxide fluxes.

Information on ecosystem productivity, especially on litter production rates is available for a wide range of ecosystems, including tropical montane forests which opens the possibility to include these data as predictors or as co-variables to improve prediction of N-oxides fluxes. However, data on litter production can be quite variable and in some studies extremely high litter production rates with large standard errors have been reported (possibly caused by animals, strong winds, etc). As a result, the close correlation of $\mathrm{N}_{2} \mathrm{O}+\mathrm{NO}$ flux with litter production that we found in our study could not be confirmed after including data from other studies carried out in tropical montane forests (Holtgrieve et al. 2006; Purbopuspito et al. 2006; Schuur \& Matson 2001). Tree basal area increment however showed a closer correlation to $\mathrm{N}_{2} \mathrm{O}+\mathrm{NO}$ fluxes compared with litter production and is probably a better long-term measure of forest productivity compared to litter fall. In addition, tree basal increment is estimated by measuring the whole 
plots and not by collecting a random sample, as is the case with litterfall. Presently the scientific community is doing considerable efforts to improve estimates of aboveground biomass and changes in aboveground biomass of tropical forests. The results of our study illustrate that in Nlimited forests these improved biomass estimates may be used to improve $\mathrm{N}$-oxide flux estimates as well. 


\subsection{References}

Adamek, M., M. D. Corre, \& D. Hölscher (2009), Early effect of elevated nitrogen input on above-ground net primary production of a lower montane rain forest, Panama, Journal of Tropical Ecology, 25, 637-647.

Amundson, R., A. T. Austin, E. A. G. Schuur, K. Yoo, V. Matzek, C. Kendall, A. Uebersax, D. Brenner, \& W. T. Baisden (2003), Global patterns of the isotopic composition of soil and plant nitrogen, Global Biogeochemical Cycles, 17(1), 1031.

Anderson, L. O., Y. Malhi, R. J. Ladle, L. Aragao, Y. Shimabukuro, O. L. Phillips, T. Baker, A. C. L. Costa, J. S. Espejo, N. Higuchi, W. F. Laurance, G. Lopez-Gonzalez, A. Monteagudo, P. Nunez-Vargas, J. Peacock, C. A. Quesada, \& S. Almeida (2009), Influence of landscape heterogeneity on spatial patterns of wood productivity, wood specific density and above ground biomass in Amazonia, Biogeosciences, 6(9), 1883-1902.

Arnold, J., M. D. Corre, \& E. Veldkamp (2009), Soil N cycling in old-growth forests across an Andosol toposequence in Ecuador, Forest Ecology and Management, 257(10), 2079-2087.

Bakwin, P. S., S. C. Wofsy, S. M. Fan, M. Keller, S. E. Trumbore, \& J. M. Dacosta (1990), Emission of nitric-oxide (NO) from tropical forest soil and exchange of NO between the forest canopy and atmospheric boundary-layers Journal of Geophysical ResearchAtmospheres, 95(D10), 16755-16764.

Bartels, R. (1982), The rank version of von Neumann ratio test for randomness, Journal of the American Statistical Association, 77(377), 40-46.

Blake, G. R., \& K. H. Hartge (1986), Bulk density, in Methods of soil analysis, part 1. Physical and mineralogical methods., edited by A. Klute, p. 12, Agronomy Monograph, Soil Science Society of America, Madison, Wisconsin, USA.

Bliese, P. D., \& R. E. Ployhart (2002), Growth Modeling Using Random Coefficient Models: Model Building, Testing, and Illustrations, Organizational Research Methods 5, 362-387.

Bowden, W. B., W. H. McDowell, C. E. Asbury, \& A. M. Finley (1992), Riparian nitrogen dynamics in two geomorphologically distinct tropical rain forest watersheds: nitrous oxide fluxes, Biogeochemistry, 18, 77-99.

Breuer, L., H. Papen, \& K. Butterbach-Bahl (2000), $\mathrm{N}_{2} \mathrm{O}$ emission from tropical forest soils of Australia, Journal of Geophysical Research-Atmospheres, 105(D21), 26353-26367.

Breuer, L., R. Kiese, \& K. Butterbach-Bahl (2002), Temperature and moisture effects on nitrification rates in tropical rain-forest soils, Soil Science Society of America Journal, 66, 834-844.

Cavelier, J., E. Tanner, \& J. Santamaria (2000), Effect of water, temperature and fertilizers on soil nitrogen net transformations and tree growth in an elfin cloud forest of Colombia, Journal of Tropical Ecology, 16, 83-99.

Clark, D. A., S. Brown, D. W. Kicklighter, J. Q. Chambers, J. R. Thomlinson, J. Ni, \& E. A. Holland (2001), Net primary production in tropical forests: An evaluation and synthesis of existing field data, Ecological Applications, 11(2), 371-384.

Corre, M. D., C. van Kessel, \& D. J. Pennock (1996), Landscape and seasonal patterns of nitrous oxide emissions in a semiarid region, Soil Science Society of America Journal, 60(6), 1806-1815. 
Corre, M. D., E. Veldkamp, J. Arnold, \& J. S. Wright (2010), Impact of elevated N input on soil $\mathrm{N}$ cycling and losses in old-growth lowland and montane forests in Panama, Ecology, 91(6), 1715-1729.

Crawley, M. J. (2009), The R book, John Wiley \& Sons Ltd, Chinchester, West Sussex.

Crutzen, P. J. (1979), Role of $\mathrm{NO}$ and $\mathrm{NO}_{2}$ in the chemistry of the troposphere and stratosphere, Annual Review of Earth and Planetary Sciences, 7, 443-472.

Davidson, E. A., \& W. Kingerlee (1997), A global inventory of nitric oxide emissions from soils, Nutrient Cycling in Agroecosystems, 48(1-2), 37-50.

Davidson, E. A., M. Keller, H. E. Erickson, L. V. Verchot, \& E. Veldkamp (2000), Testing a conceptual model of soil emissions of nitrous and nitric oxides, Bioscience, 50(8), 667680.

Emck, P. (2007), A climatology of south Ecuador - With special focus on the major Andean ridge as Atlantic - Pacific climate divide, Dissertation thesis, 275 pp, Friedrich-AlexanderUniversität Erlangen-Nürnberg, Erlangen-Nürnberg.

Erickson, H., M. Keller, \& D. E. A. (2001), Nitrogen oxide fluxes and nitrogen cycling during postagricultural succession and forest fertilization in the humid tropics, Ecosystems, 4, 6784.

Firestone, M. K., \& E. A. Davidson (1989), Microbiological basis of $\mathrm{NO}$ and $\mathrm{N}_{2} \mathrm{O}$ production and consumption in soil., in Exchange of Trace Gases between Terrestrial Ecosystems and the Atmosphere, edited by M. O. Andreae \& D. S. Schimel, pp. 7-21, John Wiley\&Sons, New York.

Grubb, P. J. (1977), Control of forest growth and distribution on wet tropical mountains: with special reference to mineral nutrition, Annual Review of Ecology and Systematics, 8, 83107.

Hall, S. J., G. P. Asner, \& K. Kitayama (2004), Substrate, climate, and land use controls over soil $\mathrm{N}$ dynamics and N-oxide emissions in Borneo, Biogeochemistry, 70(1), 27-58.

Handley, L. L., A. T. Austin, D. Robinson, C. M. Scrimgeour, J. A. Raven, T. H. E. Heaton, S. Schmidt, \& G. R. Stewart (1999), The $15 \mathrm{~N}$ natural abundance (d15N) of ecosystem samples reflects measures of water availability, Australian Journal of plant physiology, 26, 185-199.

Hart, S. C., J. M. Stark, E. A. Davidson, \& M. K. Firestone (1994), Nitrogen mineralisation, immobilisation and nitrification, methods of analysis, Part 2, microbial and biochemical properties, 985-1018 pp., Madison USA.

Heinrichs, H., H. J. Brumsack, N. Loftfield, \& N. Konig (1986), Improved pressure digestion system for biological and anorganic materials, Zeitschrift Fur Pflanzenernahrung Und Bodenkunde, 149(3), 350-353.

Holtgrieve, G. W., P. K. Jewett, \& P. A. Matson (2006), Variations in soil N cycling and trace gas emissions in wet tropical forests, Oecologia, 146(4), 584-594.

Homeier, J., F. A. Werner, S. R. Gradstein, S.-W. Breckle, \& M. Richter (2008), Potential vegetation and floristic composition of Andean forests in south Ecuador, with a focus on the RBSF, in Ecological studies: Gradients in tropical mountain ecosystem of Ecuador, edited by J. B. Erwin Beck, Ingrid Kottke, Franz Makeschin, Reinhard Mosandl, SpringerVerlag, Berlin, Heidelberg.

Homeier, J., S.-W. Breckle, S. Günter, R. T. Rollenbeck, \& C. Leuschner (2010), Tree diversity, forest structure and productivity along altitudinal and topographical gradients in a speciesrich Ecuadorian montane rain forest, Biotropica, 42(2), 140-148. 
Houlton, B. Z., D. M. Sigman, \& L. O. Hedin (2006), Isotopic evidence for large gaseous nitrogen losses from tropical rainforests, Proceedings of the National Academy of Sciences of the United States of America, 103(23), 8745-8750.

Houlton, B. Z., \& E. Bai (2009), Imprint of denitrifying bacteria on the global terrestrial biosphere, Proceedings of the National Academy of Sciences, 106(51), 21713-21716.

Ishizuka, S., A. Iswandi, Y. Nakajima, S. Yonemura, S. Sudo, H. Tsuruta, \& D. Murdiyarso (2005), The variation of greenhouse gas emissions from soils of various land-use/cover types in Jambi province, Indonesia, Nutrient Cycling in Agroecosystems, 71(1), 17-32.

IUSS Working Group WRB (2006), World reference base for soil resources 2006. , 2nd ed., FAO, Rome.

Kahmen, A., W. Wanek, \& N. Buchmann (2008), Foliar delta N-15 values characterize soil N cycling and reflect nitrate or ammonium preference of plants along a temperate grassland gradient, Oecologia, 158(2), 371-371.

Keller, M., \& W. A. Reiners (1994), Soil atmosphere exchange of nitrous-oxide, nitric-oxide, and methane under secondary succession of pasture to forest in the Atlantic lowlands of Costa-Rica Global Biogeochemical Cycles, 8(4), 399-409.

Köhler, B., M. D. Corre, E. Veldkamp, H. Wullaert, \& J. S. Wright (2009), Immediate and longterm nitrogen oxide emissions from tropical forest soils exposed to elevated nitrogen imput, Global Change Biology.

König, N., \& H. Fortmann (1996), Probenvorbereitungs-, Untersuchungs- und Elementbestimmungs-Methoden des Umweltanalytik-Labors der Niedersächsischen Forstlichen Versuchsanstalt, Reihe B, University of Göttingen, Göttingen, Germany.

Leuschner, C., G. Moser, C. Bertsch, M. Röderstein, \& D. Hertel (2007), Large altitudinal increase in tree root/shoot ratio in tropical mountain forests of Ecuador, Basic and Applied Ecology 8(3), 219-230.

Linn, D. M., \& J. W. Doran (1984), Effect of water-filled pore space on carbon dioxide and nitrous oxide production in tilled and nontilled soils., Soil Science Society of America Journal, 48, 1267-1272.

Litherland, M., J. A. Aspen, \& R. A. Lemielita (1994), The metamorphic belts of Ecuador, Overseas Memoir of the British Geological Survey, 11.

Loftfield, N., H. Flessa, J. Augustin, \& F. Beese (1997), Automated gas chromatographic system for rapid analysis of the atmospheric trace gases methane, carbon dioxide, and nitrous oxide, Journal of Environmental Quality, 26(2), 560-564.

Malhi, Y., T. R. Baker, O. L. Phillips, S. Almeida, E. Alvarez, L. Arroyo, J. Chave, C. I. Czimczik, A. Di Fiore, N. Higuchi, T. J. Killeen, S. G. Laurance, W. F. Laurance, S. L. Lewis, L. M. M. Montoya, A. Monteagudo, D. A. Neill, P. N. Vargas, S. Patino, N. C. A. Pitman, C. A. Quesada, R. Salomao, J. N. M. Silva, A. T. Lezama, R. V. Martinez, J. Terborgh, B. Vinceti, \& J. Lloyd (2004), The above-ground coarse wood productivity of 104 Neotropical forest plots, Global Change Biology, 10(5), 563-591.

Marrs, R. H., J. Proctor, A. Heaney, \& M. M. D. (1988), Changes in soil nitrogen-mineralization and nitrification along an altitudinal transect in tropical rain forest in Costa Rica, The Journal of Ecology, 76(2), 466-482.

Martinelli, L. A., M. C. Piccolo, A. R. Townsend, P. M. Vitousek, E. Cuevas, W. McDowell, G. P. Robertson, O. C. Santos, \& K. Treseder (1999), Nitrogen stable isotopic composition of leaves and soil: Tropical versus temperate forests, Biogeochemistry, 46(1-3), 45-65. 
Matson, P. A., \& P. M. Vitousek (1987), Cross-system comparisons of soil nitrogen transformations and nitrous oxide flux in tropical forest ecosystems, Global Biochemical Cycles, 1(2), 163-170.

Meixner, F. X., \& W. Eugster (1999), Effects of landscape pattern and topography on emissions and transport, John Wiley \& Sons Ltd, West Sussex.

Moser, G., D. Hertel, \& C. Leuschner (2007), Altitudinal change in LAI and stand leaf biomass in tropical montane forests: a transect study in Ecuador and a pan-tropical meta-analysis, Ecosystems, 10, 924-935.

Pennock, D. J., \& M. D. Corre (2001), Development and application of landform segmentation procedures, Soil \& Tillage Research, 58(3-4), 151-162.

Piepho, H. P., A. Büchse, \& C. Richter (2004), A mixed modelling approach for randomized experiments with repeated measures, Journal of Agronomy \& Crop Science, 190 230-247.

Purbopuspito, J., E. Veldkamp, R. Brumme, \& D. Murdiyarso (2006), Trace gas fluxes and nitrogen cycling along an elevation sequence of tropical montane forests in Central Sulawesi, Indonesia, Global Biogeochemical Cycles, 20(3), 11.

R Development Core Team (2009), R: A language and environment for statistical computing Vienna, Austria.

Reiners, W. A., M. Keller, \& K. G. Gerow (1998), Estimating rainy season nitrous oxide and methane fluxes across forest and pasture landscapes in Costa Rica, Water, Air and Soil Pollution, 105, 117-130.

Riley, R. H., \& P. M. Vitousek (1995), Nutrient dynamics and nitrogen trace gas flux during ecosystem developement in montane rain forest, Ecology, 76(1), 292-304.

Robinson, D. (2001), Delta N-15 as an integrator of the nitrogen cycle, Trends in Ecology \& Evolution, 16(3), 153-162.

Röderstein, M., D. Hertel, \& C. Leuschner (2005), Above- and below-ground litter production in three tropical montane forests in southern Ecuador, Journal of Tropical Ecology, 21, 483492.

Schlichting E., B. H. P., Stahr K. (1995), Bodenkundliches Praktikum, 2nd Edition ed., Blackwell Wissenschafts Verlag, Berlin, Wien.

Schuur, E. A. G., \& P. A. Matson (2001), Net primary productivity and nutrient cycling across a mesic to wet precipitation gradient in Hawaiian montane forest, Oecologia, 128(3), 431442.

Silver, W. L., F. N. Scatena, A. H. Johnson, T. G. Siccama, \& M. J. Sanchez (1994), Nutrient availability in a montane wet tropical forest - spatial patterns and methodological considerations, Plant and Soil, 164(1), 129-145.

Soil Survey Staff (1975), Soil taxonomy, U.S. Goverment Printing Office, Washington, D.C.

Sotta, E. D., M. D. Corre, \& E. Veldkamp (2008), Differing N status and N retention processes of soils under old-growth lowland forest in Eastern Amazonia, Caxiuana , Brazil, Soil Biology \& Biochemistry, 40(3), 740-775.

Takyu, M., S. I. Aiba, \& K. Kitayama (2002), Effects of topography on tropical lower montane forests under different geological conditions on Mount Kinabalu, Borneo, Plant Ecology, 159(1), 35-49.

Tanner, E. V. J., V. Kapos, \& W. Franco (1992), Nitrogen and phosphorus fertilization effects on venezuelan montane forest trunk growth and litterfall, Ecology, 73(1), 78-86.

Tanner, E. V. J., P. M. Vitousek, \& E. Cuevas (1998), Experimental investigation of nutrient limitation of forest growth on wet tropical mountains, Ecology, 79(1), 10-22. 
Veldkamp, E., E. A. Davidson, H. Erickson, M. Keller, \& A. Weitz (1999), Soil nitrogen cycling and nitrogen oxide emissions along a pasture chronosequence in the humid tropics of Costa Rica, Soil Biology and Biochemistry 31, 387-394.

Veneklaas, E. J. (1991), Litterfall and nutrient fluxes in 2 montane tropical rain-forests, Colombia, Journal of Tropical Ecology, 7, 319-336.

Vitousek, P. M. (1982), Nutrient cycling and nutrient use efficiency, The American Naturalist, 119(4), 553.

Vitousek, P. M. (1984), Litterfall, nutrient cycling, and nutrient limitation in tropical forests, Ecology, 65(1), 285-298.

Vitousek, P. M., G. Shearer, \& D. H. Kohl (1989), Foliar N-15 natural abundance in Hawaiian rainforest-pattern and possible mechanisms, Oecologia, 78(3), 383-388.

Vitousek, P. M., G. Gerrish, D. R. Turner, L. R. Walker, \& D. Muellerdombois (1995), Litterfall and nutrient cycling in 4 Hawaiian montane rain-forests, Journal of Tropical Ecology, 11, 189-203.

Walker, T. W., \& J. K. Syers (1976), Fate of phosphorous during pedogenesis, Geoderma, 15(1), $1-19$.

Werner, C., K. Butterbach-Bahl, E. Haas, T. Hickler, \& R. Kiese (2007), A global inventory of $\mathrm{N}_{2} \mathrm{O}$ emissions from tropical rainforest soils using a detailed biogeochemical model, Global Biogeochemical Cycles, 21(3).

Wilcke, W., S. Yasin, U. Abramowski, C. Valarezo, \& W. Zech (2002), Nutrient storage and turnover in organic layers under tropical montane rain forest in Ecuador, European Journal of Soil Science, 53, 15-27. 


\title{
CHAPTER \\ 3
}

\begin{abstract}
Atmospheric Methane Uptake by Tropical Montane Forest SoILS AND THE CONTRIBUTION OF ORganic LAYERS
\end{abstract}

Revised version accepted in Biogeochemistry 



\subsection{Abstract}

Microbial oxidation in aerobic soils is the primary biotic sink for atmospheric methane $\left(\mathrm{CH}_{4}\right)$, a powerful greenhouse gas. Although tropical forest soils are estimated to globally account for $10 \%$ to $20 \%$ of annual soil $\mathrm{CH}_{4}$ consumption $\left(15-30 \mathrm{Tg} \mathrm{CH}_{4}\right)$, limited data are available on $\mathrm{CH}_{4}$ exchange from tropical montane forests. We present the results of an extensive study on $\mathrm{CH}_{4}$ exchange from tropical montane forest soils along an elevation gradient (1000 m, $2000 \mathrm{~m}, 3000$ m) and topographic gradients (lower slope, midslope, ridge position) in southern Ecuador. We investigated soil $\mathrm{CH}_{4}$ exchange, possible controls, and the organic layer contribution to the atmospheric $\mathrm{CH}_{4}$ uptake using both, field measurements and laboratory incubations. All soils were net atmospheric $\mathrm{CH}_{4}$ sinks, with decreasing annual uptake rates from $5.9 \mathrm{~kg} \mathrm{CH}_{4}-\mathrm{C} \mathrm{ha}^{-1} \mathrm{yr}^{-1}$ at $1000 \mathrm{~m}$ to $0.6 \mathrm{~kg} \mathrm{CH}_{4}-\mathrm{C} \mathrm{ha}^{-1} \mathrm{yr}^{-1}$ at $3000 \mathrm{~m}$. Topography had no effect on soil atmospheric $\mathrm{CH}_{4}$ uptake. Positive correlations between $\mathrm{CH}_{4}$ uptake rates, mineral nitrogen and total phosphorus content of the mineral soil and with $\mathrm{CO}_{2}$ emissions indicated that the largest $\mathrm{CH}_{4}$ uptake corresponded with favorable conditions for microbial activity. Incubated organic layer profiles from the $2000 \mathrm{~m}$ and $3000 \mathrm{~m}$ sites revealed $\mathrm{CH}_{4}$ uptake of up to $70 \mu \mathrm{g} \mathrm{CH}_{4}-\mathrm{C} \mathrm{m}^{-2} \mathrm{~h}^{-1}$ in the deeper organic layers. Our results suggest that $\mathrm{CH}_{4}$ uptake in these tropical montane forest soils may be nutrient-limited. Contrary to the results from temperate regions -, the organic layer in tropical montane forest soils contributed considerably to the uptake of atmospheric $\mathrm{CH}_{4}$. The study shows that all soils were net sinks of methane and that the differentiation of elevation levels is necessary for the methane balances on regional scale.

\subsection{Introduction}

Methane $\left(\mathrm{CH}_{4}\right)$ is a trace gas with a global warming potential 21 times greater than that of carbon dioxide $\left(\mathrm{CO}_{2}\right)$ and participates in chemical reactions producing tropospheric ozone (Forster et al. 2007; Topp \& Pattey 1997). Oxidation processes are the main sink of atmospheric $\mathrm{CH}_{4}$, with the reaction of hydroxyl-radicals $(\mathrm{OH})$ in the troposphere accounting for approximately $90 \%$ of annual $\mathrm{CH}_{4}$ removal (Prather et al. 2001). Although soils can act as sinks and sources for $\mathrm{CH}_{4}$, microbial oxidation (methanotrophy) in aerated upland soils is the primary biotic sink for atmospheric $\mathrm{CH}_{4}$ (Potter et al. 1996). Two forms of methanotrophic oxidation are 
known in aerated soils. The first, low affinity oxidation, is only found near methane sources (e.g. in peat soils and rice paddies) and is performed by methylotrophic bacteria at $\mathrm{CH}_{4}$ concentrations higher than $40 \mu \mathrm{L} \mathrm{L}^{-1}$ (Conrad 1996; Le Mer \& Roger 2001). The second, high affinity oxidation, occurs at atmospheric $\mathrm{CH}_{4}$ concentrations and is responsible for atmospheric $\mathrm{CH}_{4}$ consumption by aerated soils (Conrad 1996).

The net $\mathrm{CH}_{4}$ exchange between soils and the atmosphere is controlled by soil physical and chemical properties that determine gas diffusivity, microbial activity and the balance between the processes of $\mathrm{CH}_{4}$ production (methanogenesis) and uptake (methanotrophy). Gas diffusivity is considered the primary regulating factor for $\mathrm{CH}_{4}$ consumption in soils, as the potential consumption of atmospheric $\mathrm{CH}_{4}$ by high affinity methanotrophs generally exceeds the rate of $\mathrm{CH}_{4}$ to diffuse from the atmosphere into the soil (Striegl 1993). Soil texture and soil moisture mainly control diffusivity in soils by regulating permeability and gas transport resistance, as $\mathrm{CH}_{4}$ diffuses $10^{4}$ times faster in air than in water (Dörr et al. 1993; Topp \& Pattey 1997). Organic layers are considered to affect $\mathrm{CH}_{4}$ oxidation primarily as gas diffusion barriers because they display little, if any, $\mathrm{CH}_{4}$ oxidation capacity (Butterbach-Bahl et al. 2002; Saari et al. 1998; Steinkamp et al. 2001). The removal of the organic layer led e.g. to enhanced $\mathrm{CH}_{4}$ uptake of temperate forest soils (Brumme \& Borken 1999; Saari et al. 1998). Besides substrate availability, microbial activity in soils is regulated by temperature, where increasing temperatures lead to higher microbial activity, and nutrient availability (Conrad 1996). $\mathrm{N}$ availability can indirectly affect $\mathrm{CH}_{4}$ uptake, by competition of $\mathrm{NH}_{4}{ }^{+}$with $\mathrm{CH}_{4}$ for methane oxidizing enzymes and the blocking of enzyme functions by products of $\mathrm{NH}_{4}{ }^{+}$oxidation (Schnell \& King 1994). Negative correlations between $\mathrm{CH}_{4}$ uptake rates and extractable $\mathrm{NH}_{4}^{+}$or nitrification rates have been reported in tropical regions (Mosier \& Delgado 1997; Veldkamp et al. 2001). Furthermore, net $\mathrm{CH}_{4}$ fluxes in soils are the result of $\mathrm{CH}_{4}$ production and $\mathrm{CH}_{4}$ oxidation which are regulated by spatial and temporal variability of anaerobic and aerobic microsites in the soil. Anaerobic microsites in upland soils may occur during wet periods or due to consumption of soil oxygen because of high microbial activity (Verchot et al. 2000). An enhanced occurrence of anaerobic microsites can turn soils from net sinks for atmospheric $\mathrm{CH}_{4}$ into net sources (Davidson et al. 2004; Keller \& Reiners 1994; Keller et al. 2005). 
Most tropical lowland rainforest soils are sinks for atmospheric $\mathrm{CH}_{4}$ (Kiese et al. 2003; Kiese et al. 2008; Werner et al. 2006). Uptake of atmospheric $\mathrm{CH}_{4}$ in aerobic tropical forest soils is estimated to account for about $28 \%$ of the global annual soil consumption $\left(6.2 \mathrm{Tg} \mathrm{yr}^{-1}\right.$ $\mathrm{CH}_{4}$ )(Dutaur \& Verchot 2007). Montane forests cover about 9\% of the tropics (FRA 2000) but only few studies have been conducted on $\mathrm{CH}_{4}$ fluxes in tropical montane forests (Delmas et al. 1992; Ishizuka et al. 2005; Kiese et al. 2008; Purbopuspito et al. 2006). The extreme variation in elevation and topographic gradients are likely to affect methane fluxes (e.g. increasing precipitation and decreasing temperatures at higher elevations, changes of soil moisture and the accumulation of organic matter in the organic layers). We are not aware of a study on the potential contribution of organic layers to oxidize methane in tropical montane forest soils even though thick organic layers frequently occur in these ecosystems (Edwards \& Grubb 1977).

Here, we present the results of an extensive study on $\mathrm{CH}_{4}$ exchange from tropical montane forests soils along an elevation gradient from $1000 \mathrm{~m}$ to $3000 \mathrm{~m}$ and along topographic gradients (lower slope, midslope, and ridge) in southern Ecuador. We tested the following hypotheses: 1) net uptake of atmospheric $\mathrm{CH}_{4}$ decreases with increasing elevation, 2) net uptake of atmospheric $\mathrm{CH}_{4}$ decreases with increasing organic layer thickness; 3) net uptake of atmospheric $\mathrm{CH}_{4}$ is inhibited by high $\mathrm{N}$ availability and that 4) organic layers contribute not or only little to the uptake of atmospheric $\mathrm{CH}_{4}$ in tropical montane forests soils. We investigated soil $\mathrm{CH}_{4}$ exchange, possible biogeochemical controls, and the contribution of organic layers to the atmospheric $\mathrm{CH}_{4}$ uptake using a combination of field measurements and laboratory incubations of mineral soil and organic layers.

\subsection{Methods}

\subsubsection{Study area}

The study was carried out along an elevation gradient from $1000 \mathrm{~m}$ to $3000 \mathrm{~m}$ within and close to Podocarpus National Park. The park is located in the Cordillera del Consuelo, which forms part of the eastern chain of the Andes in southern Ecuador. Three study sites were selected (Table 3.1): premontane rainforest, from 990 to $1200 \mathrm{~m}$ a.s.l. (hereafter the ' $1000 \mathrm{~m}$ site'), lower montane forest, from 1800 to $2100 \mathrm{~m}$ a.s.l. (hereafter the '2000 m site') and upper montane 
forest, from 2800 to $3000 \mathrm{~m}$ a.s.1. (hereafter the '3000 m site'). At each study site (1000 m, 2000 m, $3000 \mathrm{~m}$ ) we established 18 plots at three landscape positions: lower slope, midslope and ridge. Annual precipitation showed little seasonality (Emck 2007). For most of the study area, Paleozoic metamorphic schist and sandstones with some quartz veins form the parent material for soil development. However, at the $1000 \mathrm{~m}$ site, soil parent material of half of the plots consists of deeply weathered granitic rock of the Jurassic Zamora granitoide formation (Litherland et al. 1994). Organic layer thickness increased with elevation and from lower slope positions to ridge positions (Table 3.1), but displayed large spatial variation, ranging from 0 to 30 $\mathrm{cm}$ at the $1000 \mathrm{~m}$ site, and from 0.5 to $75 \mathrm{~cm}$ at the $2000 \mathrm{~m}$ and $3000 \mathrm{~m}$ sites. At the ridge positions of the $2000 \mathrm{~m}$ and $3000 \mathrm{~m}$ sites and to some extend at the ridges of the $1000 \mathrm{~m}$ site, thick organic layers led to Humic and Histic characterization of soil types. Soils at well-drained positions of the $1000 \mathrm{~m}$ and $2000 \mathrm{~m}$ sites classified as Eutric or Dystric Cambisols. Soils with hydromorphic properties (Stagnic Cambisols or Planosols) were found on the ridges of the 2000 $\mathrm{m}$ site and at all topographic positions of the $3000 \mathrm{~m}$ site (Chapter 2.4.1).

\subsubsection{Experimental design}

At each elevation, we established eighteen plots, six at each landscape position (lower slope, midslope and ridge positions). All plots were situated in mature, closed-canopy forest that was representative for the respective topographic position. In each plot we installed four chamber bases for gas exchange measurements in a random design along two orthogonal transects, in total 216 chambers (54 plots $\mathrm{x}$ four chambers per plot). Chamber bases were installed six months prior to the first measurements, inserting them approximately $0.02 \mathrm{~m}$ into the soil and remained in place until the end of the sampling period. Chamber lids were equipped with a Luer-Lock sampling port and a vent for pressure equilibration. Methane, soil respiration, soil moisture content, soil temperature, and soil mineral $\mathrm{N}$ were measured bi-monthly over a period of one year (May 2008 - May 2009). 
Atmospheric Mehtane Uptake by Tropical Montane Forest Solls | 53

Table 3.1: Site characteristics and soil properties of the upper mineral soil (Ah-horizon) at the topographic positions across the elevation gradient

\begin{tabular}{|c|c|c|c|c|c|c|c|c|c|}
\hline & \multicolumn{3}{|c|}{$1000 \mathrm{~m}$} & \multicolumn{3}{|c|}{$2000 \mathrm{~m}$} & \multicolumn{3}{|c|}{$3000 \mathrm{~m}$} \\
\hline & Lower slope & Midslope & Ridge & Lower slope & Midslope & Ridge & Lower slope & Midslope & Ridge \\
\hline Coordinates & \multicolumn{3}{|c|}{$04^{\circ} 06^{\prime} \mathrm{S}, 78^{\circ} 58^{\prime} \mathrm{W}$} & \multicolumn{3}{|c|}{$03^{\circ} 58^{\prime} \mathrm{S}, 79^{\circ} 04^{\prime} \mathrm{W}$} & \multicolumn{3}{|c|}{$04^{\circ} 06^{\prime} \mathrm{S}, 79^{\circ} 11^{\prime} \mathrm{W}$} \\
\hline Elevation a.s.1. (m) & \multicolumn{3}{|c|}{$990-1200$} & \multicolumn{3}{|c|}{$1800-2100$} & \multicolumn{3}{|c|}{$2800-3000$} \\
\hline Air temperature $\left({ }^{\circ} \mathrm{C}\right)^{\mathrm{a}}$ & \multicolumn{3}{|c|}{19.4} & \multicolumn{3}{|c|}{15.7} & \multicolumn{3}{|c|}{9.4} \\
\hline Precipitation $\left(\mathrm{mm} \mathrm{yr}^{-1}\right)^{\mathrm{a}}$ & \multicolumn{3}{|c|}{2230} & \multicolumn{3}{|c|}{1950} & \multicolumn{3}{|c|}{4500} \\
\hline Organic layer thickness $(\mathrm{cm})^{\mathrm{b}}$ & $2.5(0.7)$ & $2.6(1.0) \mathrm{A}$ & $6.5(1.9) \mathrm{A}$ & $4.0(0.9) \mathrm{a}$ & $12.2(3.1) \mathrm{aB}$ & $24.0(2.9) \mathrm{bB}$ & $6.6(0.7) \mathrm{a}$ & $14.2(1.6) \mathrm{abB}$ & $22.2(3.4) \mathrm{bB}$ \\
\hline \multicolumn{10}{|l|}{ Organic layer } \\
\hline $\mathrm{pH}\left(\mathrm{H}_{2} \mathrm{O}\right)^{\mathrm{b}}$ & $4.9(0.5) \mathrm{a}$ & $4.8(0.6) \mathrm{a}$ & $3.7(0.1) b$ & $4.6(0.2) \mathrm{a}$ & $4.8(0.5) \mathrm{a}$ & $3.4(0.1) \mathrm{b}$ & $4.0(0.3)$ & $3.7(0.1)$ & $3.6(0.1)$ \\
\hline $\mathrm{C}: \mathrm{N}^{\mathrm{b}}$ & $18.5(0.7) \mathrm{A}$ & $18.6(1.5) \mathrm{A}$ & $20.5(0.7) \mathrm{A}$ & $15.7(0.8) \mathrm{aB}$ & $15.6(0.6) \mathrm{aA}$ & $21.1(0.7) \mathrm{bA}$ & $20.5(0.8) \mathrm{aA}$ & $23.9(1.4) \mathrm{bB}$ & $26.7(1.3) \mathrm{cB}$ \\
\hline Total $\mathrm{P}\left(\mathrm{mg} \mathrm{g}^{-1}\right)^{\mathrm{b}}$ & $1.1(0.1)$ & $1.2(0.1) \mathrm{A}$ & $0.6(0.02) \mathrm{A}$ & $1.2(0.1) \mathrm{a}$ & $1.1(0.2) \mathrm{aA}$ & $0.5(0.0) \mathrm{bAB}$ & $0.8(0.1) \mathrm{aA}$ & $0.6(0.1) \mathrm{abB}$ & $0.4(0.02) \mathrm{bB}$ \\
\hline \multicolumn{10}{|l|}{ Mineral soil (Ah) } \\
\hline $\mathrm{pH}\left(\mathrm{H}_{2} \mathrm{O}\right)^{\mathrm{b}}$ & $5.0(0.3) \mathrm{A}$ & $5.1(0.4) \mathrm{A}$ & $4.2(0.1)$ & $4.6(0.2) \mathrm{AB}$ & $4.7(0.4) \mathrm{AB}$ & $3.7(0.1)$ & $3.7(0.1) \mathrm{B}$ & $3.7(0.0) \mathrm{B}$ & $3.7(0.1)$ \\
\hline $\mathrm{C}: \mathrm{N}^{\mathrm{b}}$ & $16.3(0.6) \mathrm{a}$ & $15.0(0.7) \mathrm{a}$ & $21.3(1.2) \mathrm{bAB}$ & $13.2(1.1)$ & $14.1(1.5)$ & $17.0(0.8) \mathrm{A}$ & $14.2(0.2) \mathrm{a}$ & $18.0(1.1) \mathrm{ab}$ & $22.3(1.0) \mathrm{bB}$ \\
\hline Total P $\left(\mathrm{mg} \mathrm{g}^{-1}\right)^{\mathrm{b}}$ & $0.7(0.2)$ & $0.8(0.2) \mathrm{A}$ & $0.6(0.1)$ & $0.5(0.1)$ & $0.7(0.1) \mathrm{AB}$ & $0.2(0.0)$ & $0.3(0.0)$ & $0.2(0.0) \mathrm{B}$ & $0.1(0.0)$ \\
\hline Sand $(\%)$ & $42.4(8.6)$ & $46.9(8.9)$ & $33.0(7.3)$ & $26.7(2.1)$ & $25.8(5.3)$ & $23.9(2.9)$ & $21.8(3.9)$ & $32.1(6.7)$ & $36.0(4.8)$ \\
\hline Silt $(\%)^{b}$ & $30.6(7.5) \mathrm{A}$ & $35.8(8.2)$ & $35.6(5.8) \mathrm{A}$ & $55.3(3.0) \mathrm{B}$ & $53.1(3.8)$ & $60.9(1.8) \mathrm{B}$ & $57.5(0.3) \mathrm{B}$ & $49.7(2.5)$ & $50.0(2.0) \mathrm{AB}$ \\
\hline Clay $(\%)^{b}$ & $26.9(2.6) \mathrm{ab}$ & $17.3(2.3) \mathrm{b}$ & $31.5(2.1) \mathrm{aA}$ & $18.1(2.1)$ & $21.1(2.1)$ & $15.2(2.1) \mathrm{B}$ & $20.7(3.6)$ & $18.2(4.3)$ & $14.1(3.3) \mathrm{B}$ \\
\hline
\end{tabular}

${ }^{a}$ Moser et al. (2007)

${ }^{b}$ Means $( \pm \mathrm{SE}, \mathrm{n}=6)$ within rows followed by different letter indicate significant differences among topographic positions at each elevation (small letters) and differences among elevations at each topographic position (capital letters) (two-way ANOVA with Tukey HSD test at $P \leq 0.05$ ) 


\subsubsection{Site characterization}

Soil characteristics of the plots were determined from 41 soil profiles $(0.5-1.5 \mathrm{~m})$ at the beginning of the study (2008). Bulk densities of the mineral soil and the organic layers were determined according to Blake and Hartge (1986). For chemical analysis, samples from the organic layer (as a pooled sample covering the whole depth of the organic layer) and from the Ah horizon were oven-dried $\left(45^{\circ} \mathrm{C}\right.$ for three days), sieved and stored in plastic bags until air transported to Germany. Total carbon $\left(\mathrm{C}_{\text {tot }}\right)$ and total nitrogen $\left(\mathrm{N}_{\text {tot }}\right)$ were determined using ground samples and a CNS Elemental Analyzer (Elementar Vario EL, Hanau, Germany). Total P $\left(\mathrm{P}_{\text {tot }}\right)$ and total base cations were measured using Inductively Coupled Plasma-Atomic Emission Spectrometer (ICP-AES; Spectro Analytical Instruments, Kleve, Germany) after pressure digestion in $65 \% \mathrm{HNO}_{3}$. Soil $\mathrm{pH}$ was measured in a suspension of soil in $\mathrm{H}_{2} \mathrm{O}$ with 1:1 and 1:10 ratio for sieved mineral soil and organic layer, respectively. Soil texture of the Ah horizon was determined by sedimentary fractionation of the clay fraction $\left(25^{\circ} \mathrm{C}, 21 \mathrm{~h}, 30 \mathrm{~cm}\right.$ fall height) following the Atterberg method after wet sieving of the sand and coarse silt fraction (630, 200, 63 and $20 \mu \mathrm{m}$ ) and destruction of organic matter with $30 \% \mathrm{H}_{2} \mathrm{O}_{2}$ and $\mathrm{Fe}$ oxides with $4 \%$ NaDithionite-Citrate solution (Schlichting et al.. 1995). Soil moisture content, soil mineral N, and soil temperature were determined at the depth of 0 to $0.05 \mathrm{~m}$ of the surface (organic layer or mineral soil), within a one meter distance of the chamber bases concomitantly with every gas sampling. We expressed soil moisture as gravimetric moisture content. Soil mineral N (ammonia $\left(\mathrm{NH}_{4}{ }^{+}\right)$and nitrate $\left(\mathrm{NO}_{3}{ }^{-}\right)$) was determined on a composite soil sample, which consisted of four subsamples per plot. In the field, part of the composite sample was added to a polyethylene bottle containing $150 \mathrm{ml}$ of 0.5 molar potassium sulfate $\left(\mathrm{K}_{2} \mathrm{SO}_{4}\right)$ solution. The remaining part of each sample was stored in a plastic bag for determination of gravimetric moisture content in the laboratory after drying for 24 hours at $105^{\circ} \mathrm{C}$. Extraction of soil mineral $\mathrm{N}$ was finished within 12 hours after field sampling to avoid shifts in $\mathrm{NH}_{4}{ }^{+}$and $\mathrm{NO}_{3}{ }^{-}$concentrations in the soil over time (Arnold et al. 2008). Extracts were filtered through filter papers (4 $\mu \mathrm{m}$ nominal pore size) after one hour of agitation, and frozen immediately after a drop of chloroform was added to prevent further $\mathrm{N}$ turnover. Samples remained frozen during transportation by air to Germany, where analysis was conducted. Ammonium and $\mathrm{NO}_{3}{ }^{-}$concentrations of the extracts were analyzed using a continuous flow injection colorimeter (Cenco/Skalar Instruments, Breda, Netherlands) (Arnold et al. 2009). 


\subsubsection{Field measurement of net $\mathrm{CH}_{4}$ exchange and soil respiration}

We measured net exchange rates of $\mathrm{CH}_{4}$ and $\mathrm{CO}_{2}$ bi-monthly over a time period of one year (May 2008-May 2009). We used static closed chambers with a base area of $0.044 \mathrm{~m}^{2}$ and a closed chamber volume of 13 liters. Gas samples were taken 2, 14, 26, and 38 minutes following chamber closure using pre-evacuated glass containers $(60 \mathrm{ml})$. Pressure was checked with a manometer during sampling to assure that containers had been evacuated properly and were filled to atmospheric pressure. Gas samples were analyzed within 48 hours following sampling using a gas chromatograph (Shimadzu GC-14B, Duisburg, Germany) equipped with a flame ionization detector (FID) and an electron capture detector (ECD) combined with an autosampler (Loftfield et al. 1997). Gas concentrations were calculated by comparing integrated peak areas of samples with four standard gases $\left(1.5,2.0,10\right.$ and $20 \mu \mathrm{L} \mathrm{L}^{-1}$ standard concentrations of $\mathrm{CH}_{4}$; and 350, 700, 1500, $5000 \mu \mathrm{L} \mathrm{L}^{-1}$ standard concentrations of $\mathrm{CO}_{2}$; Deuste Steiniger $\mathrm{GmbH}$, Mühlhausen, Germany). Methane exchange rates were calculated from the linear change of $\mathrm{CH}_{4}$ concentration in the chamber air over time, while $\mathrm{CO}_{2}$ emissions were calculated by fitting both linear and quadratic regression models if $\mathrm{CO}_{2}$ concentrations increased asymptotically (Wagner et al. 1997). Positive flux rates represent net emissions and negative values represent net uptake rates by soils. Based on the Akaike Information Criterion the quadratic model was found to be statistically more adequate and therefore applied in about $50 \%$ of the cases. By applying this data screening and model fitting, we minimized underestimations of $\mathrm{CO}_{2}$ emissions that may have occurred by using linear models uncritically with static chamber flux data (Livingston et al. 2006). Annual fluxes were calculated from the average of the bi-monthly measurementsPotential uptake of atmospheric $\mathrm{CH}_{4}$ and soil respiration at different soil depths

To determine the potential uptake of atmospheric $\mathrm{CH}_{4}$ and soil respiration at different soil depths and to determine the influence of temperature on gas flux rates, we conducted a laboratory incubation experiment. Undisturbed samples from mineral soils and organic layers were taken from selected soil profiles using stainless steel cores $\left(100 \mathrm{~cm}^{3}\right)$. We sampled 12 soil profiles of the mineral soil at the lower slope positions of the $1000 \mathrm{~m}$ site, where no organic layer was present. We sampled six mineral soil profiles from soils on deeply weathered granite and six from young, shallow soils over schist. The mineral soil profiles consist of samples from four different soil depths: 0-5 cm, 5-10 cm, 10-15 cm and 15-20 cm. Furthermore, we sampled 15 organic layer profiles from the ridge positions of the three elevations. The organic layers profiles 
were sampled in 5-cm depth intervals from the surface to the mineral soil and include two depth of the underlying mineral soil $(0-5 \mathrm{~cm}$ and 5-10 cm). We sampled three organic layer profiles over weathered granite at $1000 \mathrm{~m}$, seven organic layer profiles at $2000 \mathrm{~m}$ and five organic layer profiles at $3000 \mathrm{~m}$. Additionally, we took disturbed samples of each profile depth to determine gravimetric moisture content after drying for 24 hours at $105^{\circ} \mathrm{C}$. The undisturbed samples were transported to the laboratory of the Technical University in Loja and were incubated the next day.

We incubated soil cores at field moisture and two different temperatures $\left(15{ }^{\circ} \mathrm{C}\right.$ and $\left.25^{\circ} \mathrm{C}\right)$ under ambient air in closed glass flasks $(0.4 \mathrm{~L})$ with a septum sampling port. Soil cores were preincubated for 24 hours at the respective incubation temperature. If necessary, soil moisture was re-adjusted to the initial moisture content prior to incubation, by weighing soil cores and adding distilled water. After 90 minutes of incubation, a gas sample $(10 \mathrm{ml})$ was taken from the headspace of the flask through a septum with a gas tight syringe (SEG International, Ringwood, Australia), and the concentration of $\mathrm{CH}_{4}$ and $\mathrm{CO}_{2}$ was measured with the gas chromatograph described above. Methane fluxes and $\mathrm{CO}_{2}$ emissions were calculated as the difference of the gas concentration measured after the incubation of 90 minutes $\left(T_{1}\right)$ and the initial concentration in fresh air before the incubation flask was closed ( $\mathrm{T}_{0}$ concentration, fresh ambient air). The gas fluxes were related to the soil core surface area $\left(24 \mathrm{~cm}^{2}\right)$ and expressed as flux per square meter. After incubation, soil material was dried at $45^{\circ} \mathrm{C}$, ground and analyzed for $\mathrm{pH}, \mathrm{C}_{\text {tot }}, \mathrm{N}_{\text {tot }}, \mathrm{P}_{\text {tot }}$ and base cations as described for the soil samples above.

\subsection{5 $\mathrm{CH}_{4}$ concentration in soil air of organic layers}

To determine in situ soil air $\mathrm{CH}_{4}$ concentration at different organic layer depths, we sampled soil air in 10-cm steps from the mineral soil to the surface at the same sampling points at $2000 \mathrm{~m}$ and $3000 \mathrm{~m}$ selected for the incubation experiment. We measured 3 profiles per sampling point using a steel tube (1.8”, 60-80 cm, Alltech, Unterhaching) and pre-evacuated glass containers (20 $\mathrm{ml}$ ), after evacuating the tubing with a syringe. Gas concentrations were measured using the gas chromatograph described above. Measurements were carried out during a relatively dry period (October- November 2010) and during a wet period (February -March 2011). 


\subsubsection{Statistical analyses}

Statistical analysis of data from the field measurements was carried out on the plot mean of trace gas fluxes (average of four chambers). Linear mixed effects models (LME) were applied to test the effect of:

1) elevation and topography on time series data (i.e. bi-monthly measurements of trace gas fluxes, soil moisture and soil mineral N), with elevation and topographic position as fixed effects, and replicate plots nested in time as a random effect;

2) continuous variables (soil moisture and soil mineral $N$ ) on temporal variance of the gas fluxes, with the continuous variable as fixed effect and replicate plots nested in time as a random factor;

3) continuous variables on the spatial variability of annual gas fluxes, including topographic positions nested into the elevations as spatial random factor;

4) temperature and soil texture on trace gas fluxes of the incubated samples, with profile depth as a random factor.

5) wet and dry season, soil depth and elevation on $\mathrm{CH}_{4}$ soil air concentrations, including the hierarchical sampling structure as a spatial random factor.

We used LME for time series data because they account for temporal correlation among observations on the same experimental unit (Piepho et al. 2004) and we used LME to test spatial correlations to account for the hierarchical study design by including different error variances of the different spatial scales (Crawley 2009). Linear mixed effects models were tested for autocorrelation effects by including a first order autoregressive structure and for heteroscedasticity of residual variance by including variance functions (Bliese \& Ployhart 2002). Model residuals were tested for normal distribution and data was transformed if necessary. For testing the elevation and topography effects on data that were measured once (i.e. soil characteristics) we used two-way analysis of variance (ANOVA). The relationships among soil characteristics and annual trace gas fluxes were assessed by linear regression on the means of six plots for each topographic position ( $\mathrm{n}=9 ; 3$ topographic positions of 3 elevations). The effects of soil depth on trace gas fluxes were tested using one-way ANOVA. For multiple comparison 
after LME and ANOVA Tukey HSD test was applied. Correlations of trace gas fluxes from the incubated samples with continuous variables (i.e. carbon concentrations) were examined using generalized least square models (GLS) on the elevation mean of each profile depth. GLS models were tested for autocorrelation effects of profile depth by including a spherical correlation structure. Means with \pm 1 standard error are given in the text. Effects were accepted as statistically significant if $\mathrm{P} \leq 0.05$. Analyses were conducted using $\mathrm{R}$ version 2.10 .1 ( $\mathrm{R}$ Development Core Team 2009) and STATISTICA Service Pack 8 (StatSoft Inc., Tusla, USA).

\subsection{Results}

\subsubsection{Soil net $\mathrm{CH}_{4}$ fluxes along elevation and topographic gradients}

Atmospheric $\mathrm{CH}_{4}$ uptake of the soil decreased with increasing elevation $(\mathrm{P}<0.001)$, whereas topography did not affect atmospheric $\mathrm{CH}_{4}$ uptake. Soil net $\mathrm{CH}_{4}$ fluxes did not display a clear seasonality () and soils of all elevations and topographic positions were net sinks for atmospheric $\mathrm{CH}_{4}$ with annual mean uptake rates ranging from $0.6 \pm 1.2 \mathrm{~kg} \mathrm{CH}_{4}-\mathrm{C} \mathrm{ha}^{-1} \mathrm{yr}^{-1}$ at $3000 \mathrm{~m}$ to 5.9 $\pm 1.0 \mathrm{~kg} \mathrm{CH}_{4}-\mathrm{C} \mathrm{ha}^{-1} \mathrm{yr}^{-1}$ at $1000 \mathrm{~m}$ (Figure 3.1). Positive $\mathrm{CH}_{4}$ fluxes (emissions) occurred in $5.3 \%$ of all measurements and increased with elevation from $2.1 \%$ at $1000 \mathrm{~m}$ and $5.2 \%$ at 2000 $\mathrm{m}$ to $8.9 \%$ at $3000 \mathrm{~m}$. Variability of fluxes was highest at the lower slope position at $3000 \mathrm{~m}$ where $22 \%$ of $\mathrm{CH}_{4}$ fluxes measured were positive. We found no effect of different soil parent material (granite vs. schist) on net atmospheric $\mathrm{CH}_{4}$ uptake rates $(\mathrm{P}=0.40)$ (Table 3.3). To determine the effect of elevation and slope position on soil moisture in the top $0.05 \mathrm{~m}$ of the soil we separated results from the organic layer and the mineral soil. Gravimetric moisture content of mineral soils without organic layer, which were only found at the $1000 \mathrm{~m}$ site, was lowest at the midslope position and highest at the ridges $(\mathrm{P}=0.003)$. Gravimetric soil moisture in the top $0.05 \mathrm{~m}$ of the organic layers increased with elevation $(\mathrm{P}<0.001)$ and from the lower slope positions to the ridges at $2000 \mathrm{~m}$ and $3000 \mathrm{~m}(\mathrm{P}<0.001$, Table 3.3). We did not detect a relationship between bi-monthly measured net $\mathrm{CH}_{4}$ flux rates and soil moisture across elevations and topographic positions, neither in mineral soil nor in the organic layer. In addition, we found no significant correlation between the annual $\mathrm{CH}_{4}$ uptake and the mean soil moisture content (data not shown). 

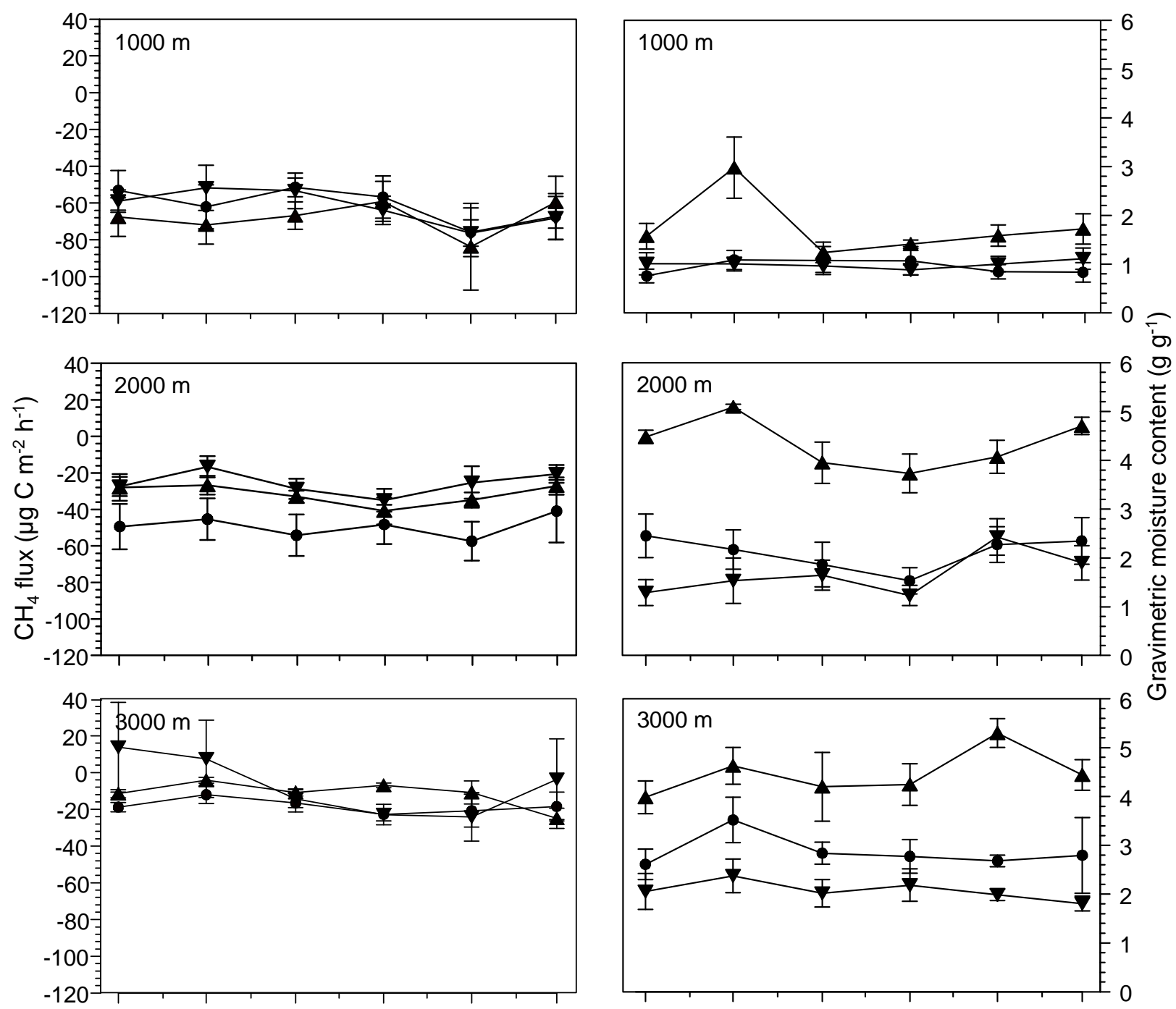

May 08 July 08 Sept 08 Nov 08 Jan 09 Mar 09

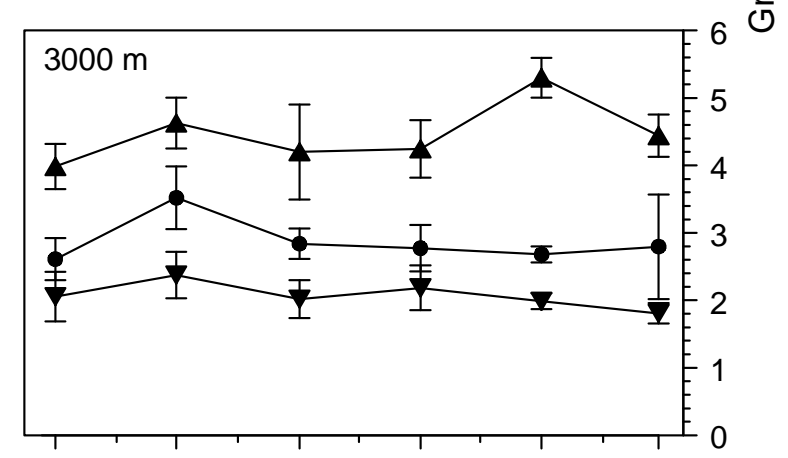

May 08 July 08 Sept 08 Nov 08 Jan 09 Mar 09

Date

Figure 3.1: Annual course of soil net $\mathrm{CH}_{4}$ exchange rates and gravimetric soil moisture (means $\pm S E, n=6$ ) of the three topographic positions ( $\nabla$ Lower slope, $\bullet$ Midslope, $\triangle$ Ridge) across the elevation gradient $(1000 \mathrm{~m}, 2000 \mathrm{~m}, 3000 \mathrm{~m})$. Negative values represent $\mathrm{CH}_{4}$ uptake rates. 
Table 3.2: Mean annual soil $\mathrm{CH}_{4}$ and $\mathrm{CO}_{2}$ fluxes (means $\pm \mathrm{SE}$ ) and parallel measured parameters of the top soil (0-5 $\left.\mathrm{cm}\right)$ at the topographic positions across the elevation gradient.

\begin{tabular}{|c|c|c|c|c|c|c|c|c|c|}
\hline & \multicolumn{3}{|c|}{$1000 \mathrm{~m}$} & \multicolumn{3}{|c|}{$2000 \mathrm{~m}$} & \multicolumn{3}{|c|}{$3000 \mathrm{~m}$} \\
\hline & Lower slope & Midslope & Ridge & Lower slope & Midslope & Ridge & Lower slope & Midslope & Ridge \\
\hline $\mathrm{CH}_{4}\left(\mathrm{~kg} \mathrm{C} \mathrm{ha}^{-1} \mathrm{yr}^{-1}\right)^{\mathrm{a}}$ & $-5.5(0.7) \mathrm{A}$ & $-5.4(0.9) \mathrm{A}$ & $-5.9(1.0) \mathrm{A}$ & $-2.3(0.3) \mathrm{B}$ & $-4.3(0.9) \mathrm{A}$ & $-2.7(0.3) \mathrm{B}$ & $-0.6(1.2) \mathrm{B}$ & $-1.6(0.4) \mathrm{B}$ & $-1.0(0.1) \mathrm{C}$ \\
\hline $\mathrm{CO}_{2}\left(\mathrm{Mg} \mathrm{Cha}^{-1} \mathrm{yr}^{-1}\right)^{\mathrm{a}}$ & $10.3(0.8) \mathrm{A}$ & $10.3(0.1) \mathrm{A}$ & $9.8(0.9) \mathrm{A}$ & $8.8(0.4) \mathrm{A}$ & $7.6(0.6) \mathrm{B}$ & $6.7(0.7) \mathrm{B}$ & $6.4(0.4) \mathrm{B}$ & $5.7(0.7) \mathrm{B}$ & $3.7(0.5) \mathrm{C}$ \\
\hline \multicolumn{10}{|c|}{ Soil parameters in $0-5 \mathrm{~cm}$} \\
\hline $\begin{array}{l}\text { Gravimetric moisture } \\
\text { mineral soil }\left(\mathrm{g} \mathrm{g}^{-1}\right)\end{array}$ & $0.1(0.2) \mathrm{a}$ & $0.6(0.1) \mathrm{a}$ & $1.7(0.03) b$ & NA & NA & NA & NA & NA & NA \\
\hline $\begin{array}{l}\text { Gravimetric moisture } \\
\text { organic layer }\left(\mathrm{g} \mathrm{g}^{-1}\right)\end{array}$ & NA & 1.7 (NA) & $1.8(0.3) \mathrm{A}$ & $1.8(0.3) \mathrm{aB}$ & $2.1(0.3) \mathrm{a}$ & $4.3(0.1) \mathrm{bB}$ & $2.1(0.2) \mathrm{a}$ & $2.9(0.3) \mathrm{a}$ & $4.5(0.3) \mathrm{bB}$ \\
\hline $\mathrm{NH}_{4}^{+}\left(\mathrm{kg} \mathrm{N} \mathrm{ha}^{-1}\right)^{\mathrm{ab}}$ & $2.2(0.4) \mathrm{A}$ & $1.8(0.5)$ & $1.5(0.5)$ & $0.8(0.2) \mathrm{B}$ & $0.9(0.3)$ & $0.9(0.2)$ & $0.6(0.1) \mathrm{aB}$ & $0.7(0.1) \mathrm{a}$ & $0.8(0.1) \mathrm{b}$ \\
\hline $\mathrm{NO}_{3}^{-}\left(\mathrm{kg} \mathrm{N} \mathrm{ha}^{-1}\right)^{\mathrm{ab}}$ & $0.4(0.1) \mathrm{A}$ & $0.4(0.1) \mathrm{A}$ & $0.6(0.3) \mathrm{A}$ & $0.4(0.1) \mathrm{aA}$ & $0.3(0.1) \mathrm{aA}$ & $0.04(0.02) \mathrm{bB}$ & $0.0 \mathrm{~B}$ & $0.02(0.01) \mathrm{B}$ & $0.03(0.01) \mathrm{B}$ \\
\hline
\end{tabular}

${ }^{a}$ Means $( \pm \mathrm{SE}, \mathrm{n}=6)$ within rows followed by different letter indicate significant differences among topographic positions at each elevation (small letters) and differences among elevations at each topographic position (capital letters) (Linear mixed effects models with Tukey HSD test at $P \leq 0.05)$.

${ }^{\mathrm{b}}$ Parameters from organic layers or mineral soil

NA: No data available, NA for standard errors if the mean belongs to one repetition 
Table 3.3: Soil characteristics and annual flux rates of $\mathrm{CH}_{4}$ and $\mathrm{CO}_{2}$ (means $\pm \mathrm{SE}$ ) of soils from two substrates of the topographic positions at $1000 \mathrm{~m}$.

\begin{tabular}{|c|c|c|c|c|c|c|}
\hline & \multicolumn{2}{|c|}{ Lower slope } & \multicolumn{2}{|c|}{ Midslope } & \multicolumn{2}{|c|}{ Ridge } \\
\hline & Schist & Granite & Schist & Granite & Schist & Granite \\
\hline Sand $(\%)^{\mathrm{ac}}$ & $24.2(2.4) \mathrm{a}$ & $60.7(5.3) b$ & $27.4(1.4) \mathrm{a}$ & $66.3(3.9) \mathrm{b}$ & $16.7(1.7) \mathrm{a}$ & $49.2(0.9) \mathrm{b}$ \\
\hline Silt $(\%)^{\mathrm{ac}}$ & $47.1(3.8) \mathrm{a}$ & $14.2(0.04) b$ & $54.0(1.0) \mathrm{a}$ & $17.7(1.7) \mathrm{b}$ & $48.1(1.0) \mathrm{a}$ & $23.1(3.5) b$ \\
\hline Clay $(\%)^{\mathrm{ac}}$ & $28.7(1.5)$ & $25.1(5.3)$ & $18.6(2.2) \mathrm{a}$ & $16.1(4.4) \mathrm{a}$ & $35.2(0.7) \mathrm{a}$ & $27.8(2.6) b$ \\
\hline $\mathrm{pH}\left(\mathrm{H}_{2} \mathrm{O}\right){ }^{\mathrm{ac}}$ & $5.4(0.2)$ & $4.5(0.4)$ & $5.9(0.3) \mathrm{a}$ & $4.3(0.3) b$ & $3.9(0.1) \mathrm{a}$ & $4.5(0.1) b$ \\
\hline $\mathrm{C}: \mathrm{N}^{\mathrm{ac}}$ & $16.3(0.6)$ & $16.4(1.2)$ & $14.5(1.5)$ & $15.6(0.2)$ & $19.0(0.9) \mathrm{a}$ & $23.7(0.8) b$ \\
\hline Total P $\left(\mathrm{mg} \mathrm{g}^{-1}\right)^{\mathrm{ac}}$ & $1.1(0.1) \mathrm{a}$ & $0.3(0.02) b$ & $1.4(0.2) \mathrm{a}$ & $0.3(0.1) b$ & $0.8(0.04) \mathrm{a}$ & $0.4(0.1) b$ \\
\hline $\mathrm{NH}_{4}^{+}\left(\mathrm{kg} \mathrm{N} \mathrm{ha}^{-1}\right)^{\mathrm{bd}}$ & $2.8(0.6)$ & $1.5(0.2)$ & $1.0(0.4)$ & $2.7(0.3)$ & $2.7(0.2)$ & $0.4(0.1)$ \\
\hline $\mathrm{NO}_{3}^{-}\left(\mathrm{kg} \mathrm{N} \mathrm{ha}^{-1}\right)^{\mathrm{bd}}$ & $0.4(0.2)$ & $0.3(0.03)$ & $0.2(0.04)$ & $0.5(0.2)$ & $1.1(0.3) \mathrm{a}$ & $0.01(0.01) b$ \\
\hline $\mathrm{CH}_{4}\left(\mathrm{kgCha} \mathrm{Crr}^{-1}\right)^{\mathrm{b}}$ & $-5.0(0.7)$ & $-6.0(1.4)$ & $-5.1(1.3)$ & $-5.6(1.5)$ & $-8.0(0.5) \mathrm{a}$ & $-3.8(0.8) b$ \\
\hline $\mathrm{CO}_{2}(\mathrm{Mg} \mathrm{C}$ ha-1 yr-1) b & $10.1(0.3)$ & $10.4(1.6)$ & $8.7(0.3)$ & $11.8(2.7)$ & $11.4(0.5)$ & $8.3(1.2)$ \\
\hline
\end{tabular}

${ }^{\mathrm{a}}$ Means $( \pm \mathrm{SE}, \mathrm{n}=3$ ) within rows followed by different letter indicate significant differences among the substrates (small letters) (one-way ANOVA at $P \leq 0.05$ ).

${ }^{\mathrm{b}}$ Means $( \pm \mathrm{SE}, \mathrm{n}=3)$ within rows followed by different letter indicate significant differences among the substrates (small letters) (Linear mixed effects models for time series data at $P \leq 0.05$ ).

${ }^{\mathrm{c}}$ Parameters were taken from the Ah horizon

$\mathrm{d}$ Parameters were taken from the top $5 \mathrm{~cm}$ of the soil (including mineral soil or organic layer) 
Atmospheric $\mathrm{CH}_{4}$ uptake of the soil increased with increasing soil temperature along the elevation gradient $\left(\mathrm{P}<0.001, \mathrm{R}^{2}=0.89\right), \mathrm{NO}_{3}{ }^{-}$content $\left(\mathrm{P}<0.001, \mathrm{R}^{2}=0.72\right)$ and $\mathrm{NH}_{4}{ }^{+}$content $\left(\mathrm{P}<0.002, \mathrm{R}^{2}=0.72\right)$ of the top $0.05 \mathrm{~m}$ (mineral soil or organic layer) and with increasing $\mathrm{P}_{(\mathrm{tot})}$ $\left(\mathrm{P}<0.001, \mathrm{R}^{2}=0.66\right)$ and $\mathrm{pH}$ value of the upper mineral soil $\left(\mathrm{P}=0.02, \mathrm{R}^{2}=0.51\right)$. Smaller scale soil temperature changes within the elevation levels, organic layer thickness, $\mathrm{P}_{\text {tot }}, \mathrm{C}: \mathrm{N}$ ratios and the $\mathrm{pH}$ value of the organic layer did not affect atmospheric $\mathrm{CH}_{4}$ uptake. Annual $\mathrm{CO}_{2}$ emissions and annual $\mathrm{CH}_{4}$ uptake by soils with and without organic layers were correlated positively across all elevations $\left(\mathrm{P}<0.01, \mathrm{R}^{2}=0.66\right.$, Figure $\left.3.2 \mathrm{a}\right)$. When considering only gas fluxes from the soils covered by an organic layer, this correlation was even stronger $\left(P=0.02, R^{2}=0.74\right)$, while the correlation in mineral soils without organic layer was not significant $\left(P=0.13, \mathrm{R}^{2}=0.13\right)$.
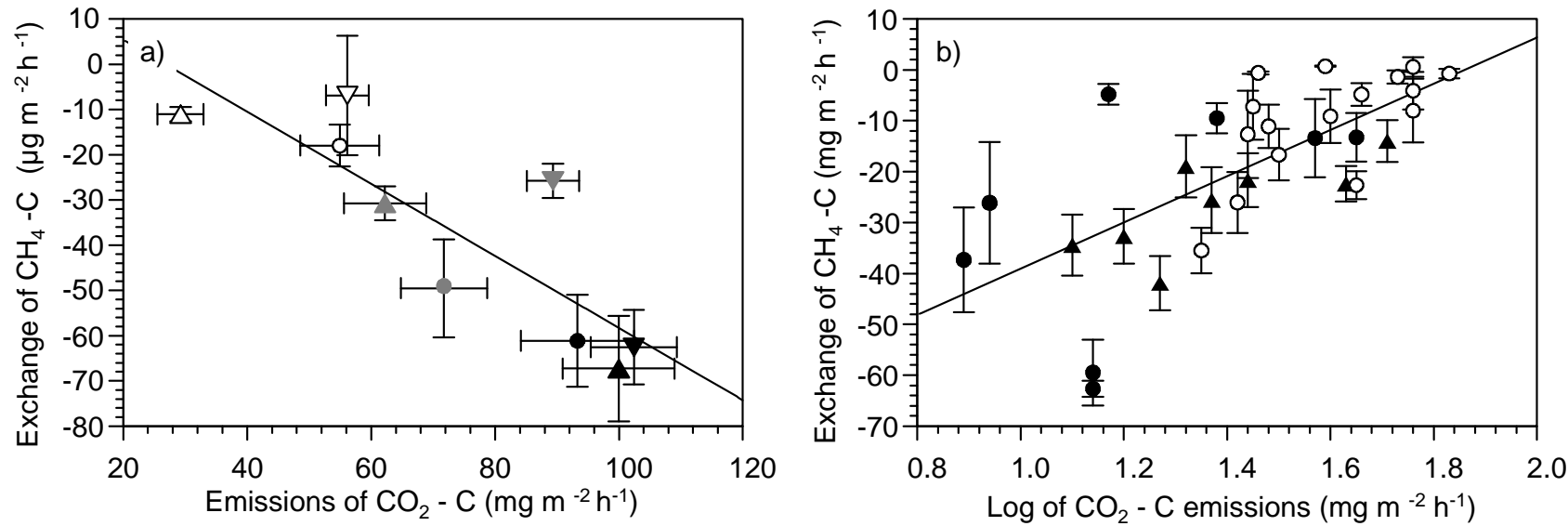

Figure 3.2: Relation between soil $\mathrm{CO}_{2}$ emission rates and soil $\mathrm{CH}_{4}$ uptake rates (means $\pm \mathrm{SE}$ ) for a) flux rates measured in the field at different topographic positions ( $\nabla$ Lower slope, - Midslope, $\triangle$ Ridge) across the elevation gradient (black: $1000 \mathrm{~m}$; full grey: $2000 \mathrm{~m}$; open: $3000 \mathrm{~m})(\mathrm{y}=\mathbf{- 2 1 . 3 8}$ $+0.80 * x, n=9 P=0.005, R^{2}=0.66$ ), and for $\left.b\right)$ undisturbed, field-moist soil samples at different depths of the organic material (open symbols) and the mineral soil (black symbols), incubated at $25^{\circ} \mathrm{C}$ in the laboratory $\left(\mathrm{y}=\mathbf{- 8 4 . 4 9}+45.42 * \mathrm{x}, \mathrm{n}=32, P<0.001, R^{2}=0.45\right)$. Symbols used: black circles, mineral soil with overlying organic layer, black triangles, mineral soil without overlying organic layer; open circles, organic layer samples. 


\subsubsection{Potential uptake of atmospheric $\mathrm{CH}_{4}$ at different soil depths}

All incubated, undisturbed samples from the mineral soil profiles (profiles of the $1000 \mathrm{~m}$ site, which had no organic layer) were net sinks for atmospheric methane (Figure 3.3). Methane uptake rates ranged from 3.5 to $60.5 \mu \mathrm{g} \mathrm{CH}_{4}-\mathrm{C} \mathrm{m}^{-2} \mathrm{~h}^{-1}$ with the highest uptake rate of atmospheric $\mathrm{CH}_{4}$ at a soil depth of $5-10 \mathrm{~cm}(\mathrm{P}=0.05)$. The incubated mineral soil profiles from the coarse textured granite substrate displayed a higher potential uptake of atmospheric $\mathrm{CH}_{4}$ than the profiles from the fine textured schist substrate $(\mathrm{P}<0.001)$ (Figure 3.3).

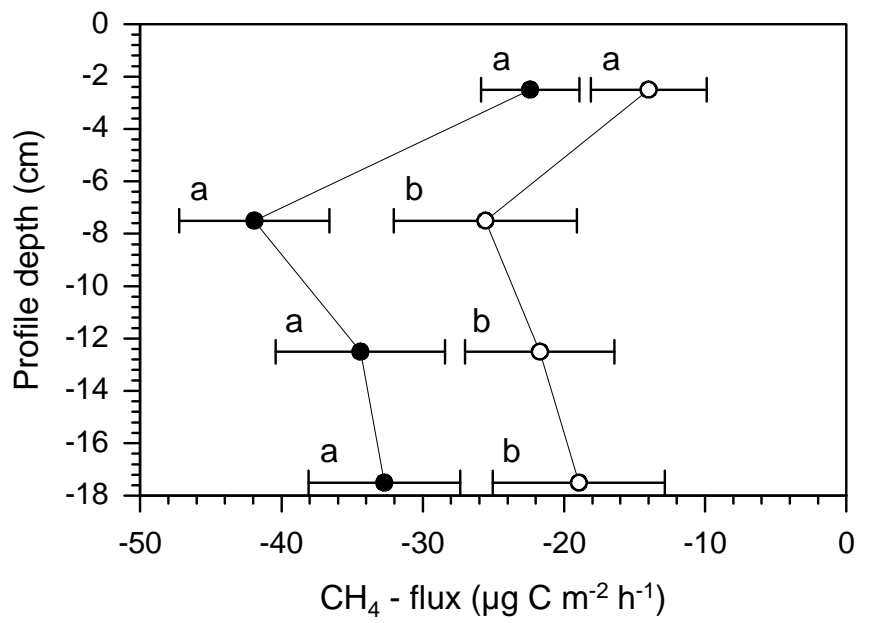

Figure 3.3: Mean $\mathrm{CH}_{4}$ uptake rates of undisturbed field moist-soil samples at different depths of the mineral soil profiles, which had no organic layer in schist (open symbols) and granite (black symbols) material at $1000 \mathrm{~m}$, incubated at $25^{\circ} \mathrm{C}$ in the laboratory. Means $( \pm \mathrm{SE}, \mathrm{n}=6)$ within one depth followed by different letter indicate significant differences among the substrates (KruskalWallis-Test at $\boldsymbol{P} \leq \mathbf{0 . 0 5}$ ).

Incubated organic layer samples generally acted as sinks for atmospheric $\mathrm{CH}_{4}$, except for the samples from the top $5 \mathrm{~cm}$, which contained mainly roots and fresh plant residues and emitted $\mathrm{CH}_{4}$ in $65 \%$ of the cases (Figure 3.4). The incubated organic material from the $1000 \mathrm{~m}$ site showed a potential $\mathrm{CH}_{4}$ uptake ranging from -0.2 to $-29.7 \mu \mathrm{g} \mathrm{CH}_{4}-\mathrm{C} \mathrm{m}^{-2} \mathrm{~h}^{-1}$. The potential $\mathrm{CH}_{4}$ uptake in the organic material from $2000 \mathrm{~m}$ ranged from +3.1 (emission!) to $-55.8 \mu \mathrm{g} \mathrm{CH}_{4}-\mathrm{C} \mathrm{m}^{-}$ ${ }^{2} \mathrm{~h}^{-1}$ and from +12.9 to $-54.5 \mu \mathrm{g} \mathrm{CH}_{4}-\mathrm{C} \mathrm{m}^{-2} \mathrm{~h}^{-1}$ in the organic material from $3000 \mathrm{~m}$. Potential $\mathrm{CH}_{4}$ uptake of atmospheric $\mathrm{CH}_{4}$ in the mineral soil underlying the organic layers was higher at $1000 \mathrm{~m}$ than at $2000 \mathrm{~m}$ or $3000 \mathrm{~m}(\mathrm{P}<0.01)$, with uptake rates ranging from 7.5 to $70.0 \mu \mathrm{g} \mathrm{CH}_{4^{-}}$ 
$\mathrm{C} \mathrm{m}^{-2} \mathrm{~h}^{-1}$ at $1000 \mathrm{~m}$, from 0.8 to $24.4 \mu \mathrm{g} \mathrm{CH}_{4}-\mathrm{C} \mathrm{m}^{-2} \mathrm{~h}^{-1}$ at $2000 \mathrm{~m}$ and from -3.4 to $33.4 \mu \mathrm{g} \mathrm{CH}_{4}-$ $\mathrm{C} \mathrm{m}^{-2} \mathrm{~h}^{-1}$ at $3000 \mathrm{~m}$.
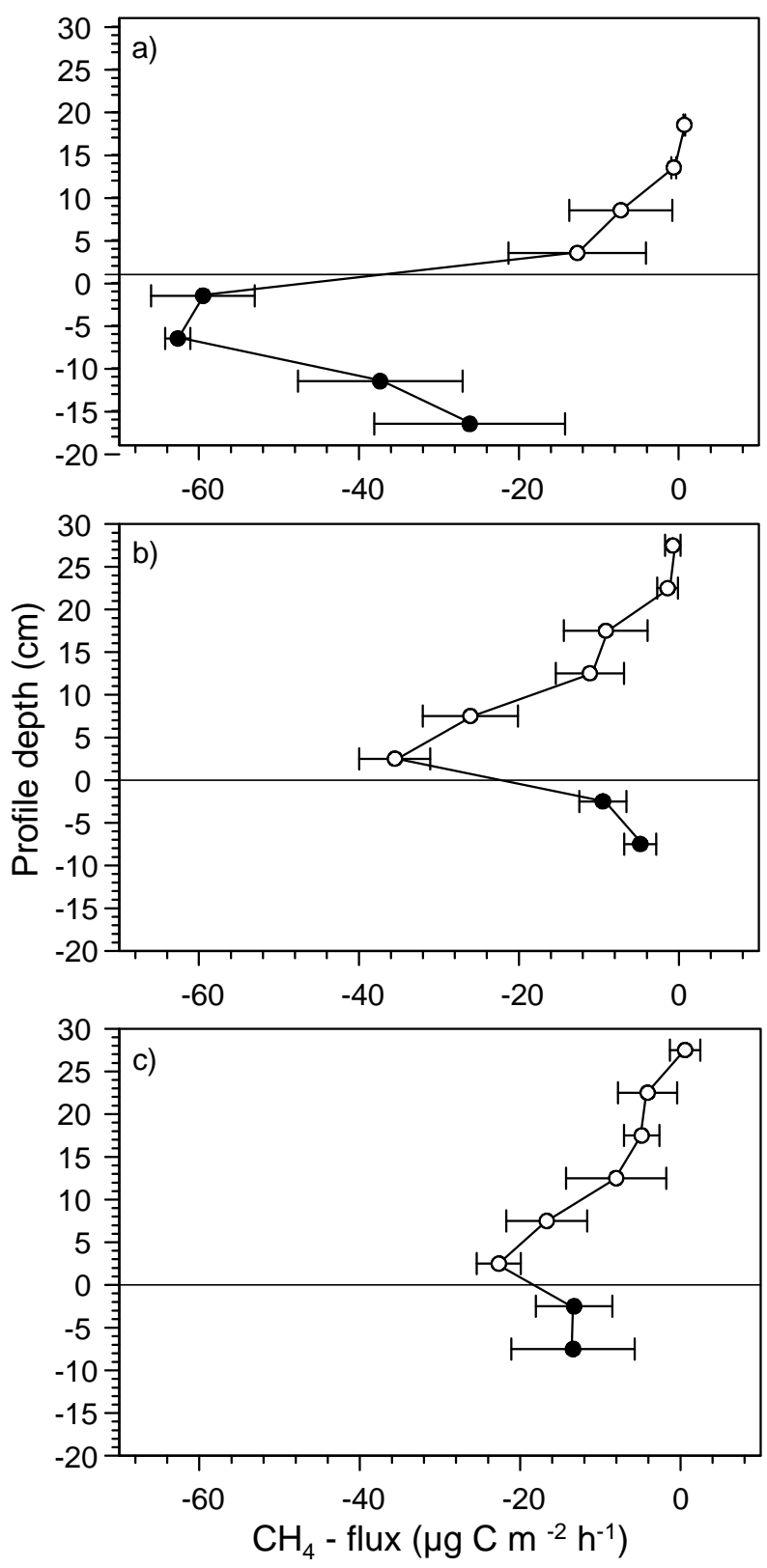

Figure 3.4: Mean $\mathrm{CH}_{4}$ fluxes ( $\pm \mathrm{SE}$ ) of undisturbed, field-moist soil samples from different depths of the organic layer (open symbols) and the mineral soil (black symbols) incubated at $25^{\circ} \mathrm{C}$ in the laboratory. The samples were taken from a) the $1000 \mathrm{~m}$ site $(\mathrm{n}=3)$, b) the $2000 \mathrm{~m}$ site $(\mathrm{n}=7)$ and c) the $3000 \mathrm{~m}$ site $(\mathrm{n}=\mathbf{5})$. 
We found a clear stratification of the potential atmospheric $\mathrm{CH}_{4}$ uptake rates within the sampled organic layer profiles. The $\mathrm{CH}_{4}$ uptake rates in the organic layer profiles from all elevations increased with increasing profile depth $(\mathrm{P}<0.00$, Figure 3.4). At the $1000 \mathrm{~m}$ site, potential $\mathrm{CH}_{4}$ uptake of the underlying mineral soil was higher than the organic material $(\mathrm{P} \leq$ 0.05 , Figure $3.4 \mathrm{a}$ ). At the $2000 \mathrm{~m}$ and the $3000 \mathrm{~m}$ sites potential atmospheric $\mathrm{CH}_{4}$ uptake was largest at the deepest organic layer overlying the mineral soil (Figure $3.4 \mathrm{~b}$, c). Organic layer thickness did not affect the potential atmospheric $\mathrm{CH}_{4}$ uptake of the underlying mineral soil.

Carbon dioxide emissions from the incubated mineral soil and organic layer profiles were largest in the top soil samples, ranging from 31.1 to $68.2 \mathrm{mg} \mathrm{CO}_{2}-\mathrm{C} \mathrm{m}^{-2} \mathrm{~h}^{-1}$ in the mineral soil and from 28.9 to $140.9 \mathrm{mg} \mathrm{CO}_{2}-\mathrm{C} \mathrm{m}^{-2} \mathrm{~h}^{-1}$ in the organic layer. Soil respiration decreased with soil depth of all profiles (data not shown). Temperature manipulation affected soil respiration from samples of the organic layer from all elevations $(\mathrm{P}<0.001)$, whereas it did not affect soil respiration of the mineral soil samples $(\mathrm{P}=0.2)$. A temperature increase from 15 to $25^{\circ} \mathrm{C}$ resulted in a doubling of the $\mathrm{CO}_{2}$ emissions rates from samples of the organic layer as shown by the doubling of the slope of the regression function (Figure 3.5 a). Temperature manipulation did neither affect $\mathrm{CH}_{4}$ uptake rates of samples from the organic layer profiles during the incubation Figure $3.5 \mathrm{~b}$ ), nor did it affect the $\mathrm{CH}_{4}$ uptake rates of the mineral soil profiles (data not shown). 

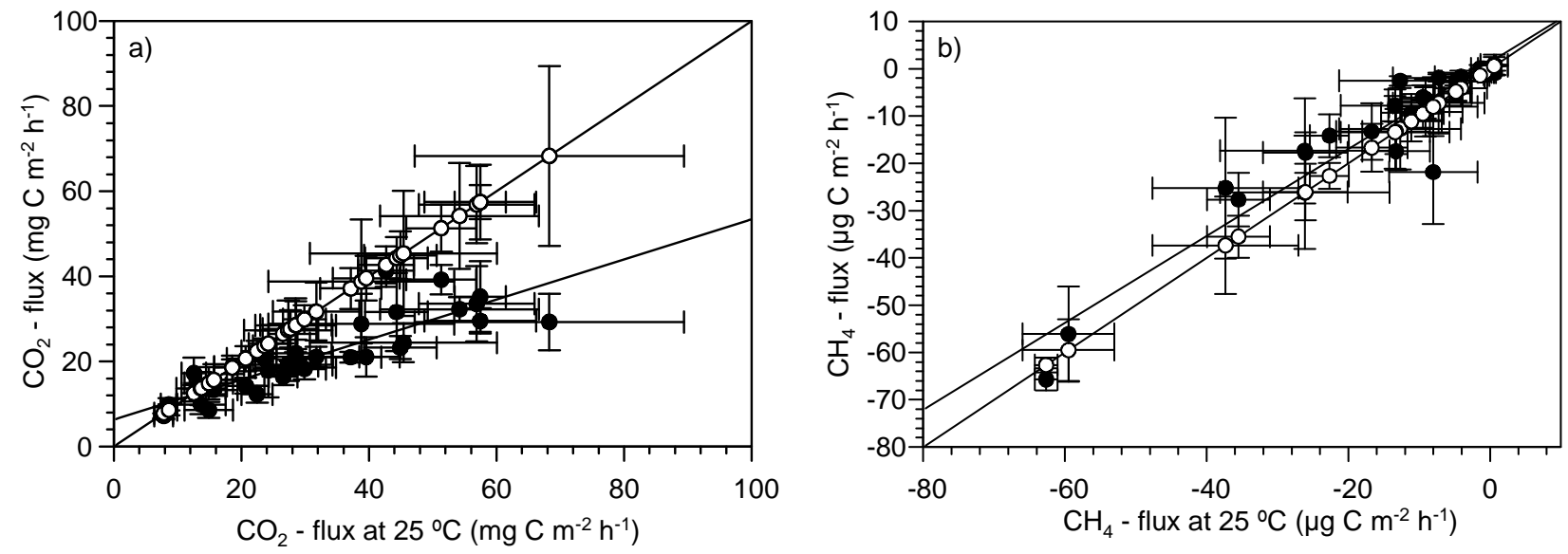

Figure 3.5: Relation between mean $( \pm \mathrm{SE})$ trace gas fluxes of undisturbed, field-moist samples of the mean organic layer profile from each elevation incubated at $25^{\circ} \mathrm{C}$ (open symbols) and $15^{\circ} \mathrm{C}$ (black symbols) for a) $\mathrm{CO}_{2}$ fluxes $\left(\mathrm{y}=7.0+0.4 * \mathrm{x}, \mathrm{n}=16, P=0.006, \mathrm{R}^{2}=0.74\right)$ and $\left.\mathrm{b}\right) \mathrm{CH}_{4}$ fluxes $(\mathrm{y}=$ $\left.0.6+0.7 * x, n=16, P=0.01, R^{2}=0.67\right)$.

Throughout the elevations, potential $\mathrm{CH}_{4}$ uptake of the incubated mineral soil profiles and organic layer profiles increased with decreasing basal respiration $\left(\mathrm{P}<0.001, \mathrm{R}^{2}=0.45\right.$, Figure $3.2 \mathrm{~b}$ ). Throughout the elevation gradient, potential atmospheric $\mathrm{CH}_{4}$ uptake of the incubated organic material did not correlate with total carbon content, cation concentration, gravimetric moisture content, or $\mathrm{pH}$-values. However, potential $\mathrm{CH}_{4}$ uptake of organic material from the $1000 \mathrm{~m}$ site correlated positively with $\mathrm{P}_{\text {tot }}$ content of the organic material $\left(\mathrm{P}=0.03, \mathrm{R}^{2}=0.90\right)$. In contrast, potential $\mathrm{CH}_{4}$ uptake of organic material of the $2000 \mathrm{~m}$ site increased with decreasing total carbon content $\left(\mathrm{P}=0.04 ; \mathrm{R}^{2}=0.62\right)$, calcium $\left(\mathrm{Ca}^{2+}, \mathrm{P}=0.01 ; \mathrm{R}^{2}=0.78\right)$ and magnesium $\left(\mathrm{Mg}^{2+}, \mathrm{P}=0.01 ; \mathrm{R}^{2}=0.78\right)$ concentrations and $\mathrm{pH}$-values $\left(\mathrm{P}<0.01 ; \mathrm{R}^{2}=0.91\right)$ of the organic material.

\subsection{3 $\mathrm{CH}_{4}$ concentrations in the soil air of organic layers}

Methane concentration in the soil air decreased with soil depth $(\mathrm{P}<0.0001$ for both elevations), both during wet and dry periods, with lowest $\mathrm{CH}_{4}$ concentrations above the mineral soil (Figure 3.6). Methane concentrations were higher during the dry period measurements compared to the wet period measurements $(\mathrm{P}<0.0001$ for both elevations) (Figure 3.6). Elevation did not affect $\mathrm{CH}_{4}$ concentration in the soil air of the organic layers neither during the 
wet nor during the dry period. $\mathrm{CH}_{4}$ concentration in soil air was always lower than the atmospheric concentration and there was no evidence of in situ net production of $\mathrm{CH}_{4}$ within the soil profile.

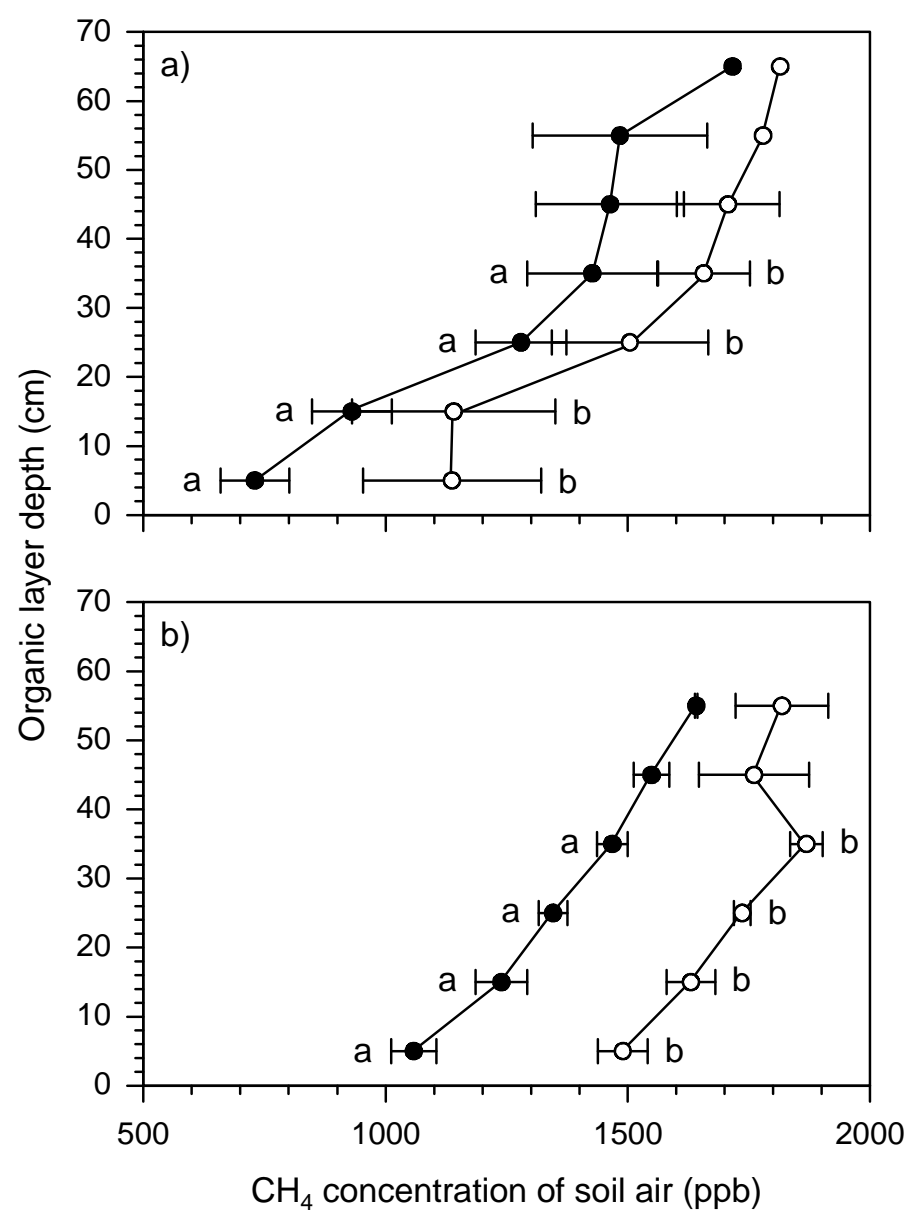

Figure 3.6: Mean soil air $\mathrm{CH}_{4}$ concentrations $( \pm \mathrm{SE})$ at different depths of the organic layer during a wet period (black symbols) and a dry period (open symbols), from the a) $2000 \mathrm{~m}$ site and b) the 3000 m site 


\subsection{Discussion}

\subsubsection{Net exchange of $\mathrm{CH}_{4}$ under field conditions}

Annual $\mathrm{CH}_{4}$ uptake rates under field conditions at the $2000 \mathrm{~m}$ and $3000 \mathrm{~m}$ sites were comparable to those reported for tropical montane forest soils at comparable elevation in Indonesia (1.5 and $3.3 \mathrm{~kg} \mathrm{CH}_{4}-\mathrm{C} \mathrm{ha}{ }^{-1} \mathrm{yr}^{-1}$ ) (Ishizuka et al. 2005; Purbopuspito et al. 2006). Annual $\mathrm{CH}_{4}$ fluxes at the $1000 \mathrm{~m}$ site were larger than previously reported for other premontane forests in Africa (Delmas et al. 1992), Australia (Kiese et al. 2008), Indonesia (Purbopuspito et al. 2006) and China (Werner et al. 2006) and were also larger than those reported from lowland forests in Costa Rica (Keller \& Reiners 1994; Reiners et al. 1998) and Brazil (Keller et al. 2005). Instead the 5.4 to $5.9 \mathrm{~kg} \mathrm{CH}_{4}-\mathrm{C} \mathrm{ha}^{-1} \mathrm{yr}^{-1} \mathrm{CH}_{4}$ uptake rates at our $1000 \mathrm{~m}$ site were comparable to $\mathrm{CH}_{4}$ fluxes from temperate beech forests (Butterbach-Bahl \& Papen 2002b) and temperate spruce forest ecosystems (Steinkamp et al. 2001).

Both the increased incidence of net $\mathrm{CH}_{4}$ emission rates with increasing elevation and a general decrease in $\mathrm{CH}_{4}$ uptake rates resulted in decreased annual net $\mathrm{CH}_{4}$ uptake with elevation. This trend was mirrored by the maximum $\mathrm{CH}_{4}$ uptake rates measured for the incubated soil samples and by the less pronounced decline of soil air $\mathrm{CH}_{4}$ concentrations in the organic layers at the drier $3000 \mathrm{~m}$ site. The lack of influence of topography on $\mathrm{CH}_{4}$ uptake that we detected supports results from forest sites in Costa Rica where no differences in $\mathrm{CH}_{4}$ uptake between topographic positions was detected (Reiners et al. 1998). Furthermore we found no evidence that seasonal water-logging turned net methane-oxidizing tropical forest soils into net $\mathrm{CH}_{4}$ sources as reported for seasonal lowland rain forests in Brazil (Davidson et al. 2004; Verchot et al. 2000). Seasonal variation in soil water condition in our study area was rather limited because of the largely non-seasonal climate.

\subsection{2 $\mathrm{CH}_{4}$ fluxes and their controls}

In contrast to the general idea that soil moisture content is an important driver for $\mathrm{CH}_{4}$ fluxes (Butterbach-Bahl 2004; Curry 2007; Davidson et al. 2004; Keller \& Reiners 1994), neither temporal nor spatial variability of net $\mathrm{CH}_{4}$ exchange could be explained by it. We believe that there are several reasons in our study for this lack of correlation between soil moisture content 
and net exchange of atmospheric $\mathrm{CH}_{4}$. First, the absence of a pronounced dry season and the resulting minimal variations in soil moisture content hamper the quantification of seasonal soil moisture effects. A similar justification was used to explain the lack of correlation between $\mathrm{CH}_{4}$ flux and soil moisture in Indonesia (Purbopuspito et al. 2006; Veldkamp et al. 2008). Second, we measured soil moisture content in the top $5 \mathrm{~cm}$ of the soil only, whereas the main $\mathrm{CH}_{4}$ uptake activity was located in different depths of the organic layer and mineral soil. Finally, it is unlikely that moisture contents in the highly porous, coarse material of the upper organic layer are high enough to restrict $\mathrm{CH}_{4}$ diffusion into the soil. Evidence for this is provided by the relatively slow decline of in situ soil air $\mathrm{CH}_{4}$ concentrations, especially at the $3000 \mathrm{~m}$ site. Our incubation of mineral soil from different geological substrates corroborates findings that coarser soil texture leads to larger potential atmospheric $\mathrm{CH}_{4}$ uptake as a result of higher gas diffusivity (Dörr et al. 1993; Saari et al. 1997). However, this texture effect did not explain the spatial variability of atmospheric $\mathrm{CH}_{4}$ uptake observed in our field measurements. We found no evidence that landscape differentiation using the geological substrate or soil texture would improve estimates of soil $\mathrm{CH}_{4}$ uptake in this region. This finding contrasts with studies in temperate forest ecosystems where soil texture was identified as a main control of soil uptake of atmospheric $\mathrm{CH}_{4}$ (Saari et al. 1997).

We found no indication that ammonium inhibition of methanotrophic bacteria was a control mechanism for $\mathrm{CH}_{4}$ uptake (Brumme et al. 2005; Guckland et al. 2009). On the contrary, we detected positive correlations between soil mineral $\mathrm{N}$ content and annual $\mathrm{CH}_{4}$ uptake which suggests that methanotrophic activity may have been $\mathrm{N}$ limited. This finding supports the findings of other studies carried out in several ecosystems that show a lower oxidation activity due to nitrogen limitation (Brodelier et al. 2004). Furthermore, positive correlations with $\mathrm{P}_{\text {tot }}$ content, $\mathrm{pH}$-value of the $\mathrm{Ah}$ horizon and field $\mathrm{CO}_{2}$ emissions suggest that higher $\mathrm{CH}_{4}$ uptake occurred at those locations where conditions were generally more favorable for microbial activity.

\subsection{3 $\mathrm{CH}_{4}$ fluxes and their controls}

In contrast to the general idea that soil moisture content is an important driver for $\mathrm{CH}_{4}$ fluxes (Butterbach-Bahl 2004; Curry 2007; Davidson et al. 2004; Keller \& Reiners 1994), neither temporal nor spatial variability of net $\mathrm{CH}_{4}$ exchange could be explained by it. We believe that 
there are several reasons in our study for this lack of correlation between soil moisture content and net exchange of atmospheric $\mathrm{CH}_{4}$. First, the absence of a pronounced dry season and the resulting minimal variations in soil moisture content hamper the quantification of seasonal soil moisture effects. A similar justification was used to explain the lack of correlation between $\mathrm{CH}_{4}$ flux and soil moisture in Indonesia (Purbopuspito et al. 2006; Veldkamp et al. 2008). . Second, we measured soil moisture content in the top $5 \mathrm{~cm}$ of the soil only, whereas the main $\mathrm{CH}_{4}$ uptake activity was located in different depths of the organic layer and mineral soil. Finally, it is unlikely that moisture contents in the highly porous, coarse material of the upper organic layer are high enough to restrict $\mathrm{CH}_{4}$ diffusion into the soil. Evidence for this is provided by the relatively slow decline of in situ soil air $\mathrm{CH}_{4}$ concentrations, especially at the $3000 \mathrm{~m}$ site. Our incubation of mineral soil from different geological substrates corroborates findings that coarser soil texture leads to larger potential atmospheric $\mathrm{CH}_{4}$ uptake as a result of higher gas diffusivity (Dörr et al. 1993; Saari et al. 1997). However, this texture effect did not explain the spatial variability of atmospheric $\mathrm{CH}_{4}$ uptake observed in our field measurements. We found no evidence that landscape differentiation using the geological substrate or soil texture would improve estimates of soil $\mathrm{CH}_{4}$ uptake in this region. This finding contrasts with studies in temperate forest ecosystems where soil texture was identified as a main control of soil uptake of atmospheric $\mathrm{CH}_{4}$ (1997).

We found no indication that ammonium inhibition of methanotrophic bacteria was a control mechanism for $\mathrm{CH}_{4}$ uptake (Brumme et al. 2005; Guckland et al. 2009). On the contrary, we detected positive correlations between soil mineral $\mathrm{N}$ content and annual $\mathrm{CH}_{4}$ uptake which suggests that methanotrophic activity may have been $\mathrm{N}$ limited. Furthermore, positive correlations with $\mathrm{P}_{\text {tot }}$ content, $\mathrm{pH}$-value of the $\mathrm{Ah}$ horizon and field $\mathrm{CO}_{2}$ emissions suggest that higher $\mathrm{CH}_{4}$ uptake occurred at those locations where conditions were generally more favorable for microbial activity.

\subsubsection{Stratification of potential uptake of atmospheric $\mathrm{CH}_{4}$ in mineral soil and organic layers}

The detected stratification of atmospheric $\mathrm{CH}_{4}$ uptake in the incubated mineral soil profiles, with highest potential $\mathrm{CH}_{4}$ uptake at a soil depth of 5-10 cm confirms findings of studies from temperate and subarctic forest soils (Schnell \& King 1994). The subsurface location of maximum $\mathrm{CH}_{4}$ oxidation is probably due to edaphic factors in the surface layer, that are suboptimal or 
inhibitory for the growth of $\mathrm{CH}_{4}$ oxidizing bacteria, e.g. high $\mathrm{NH}_{4}{ }^{+}$concentrations and the occurrence of anaerobic microsites. The negative relationship between $\mathrm{CO}_{2}$ production and atmospheric $\mathrm{CH}_{4}$ consumption of our incubated soil samples, may be the result of $\mathrm{CH}_{4}$ inhibition by $\mathrm{NH}_{4}{ }^{+}$released due to rapid $\mathrm{N}$-mineralization of organic matter. We can, however, not exclude that this is an artifact of our incubation, as under field conditions an accumulation of $\mathrm{NH}_{4}{ }^{+}$would normally not happen due to plant uptake (see also Arnold, 2008). In addition to inhibition by accumulated $\mathrm{NH}_{4}{ }^{+}$, stratification of potential $\mathrm{CH}_{4}$ uptake may also be due to the sensitivity of microorganisms to temperature and soil moisture changes, which are more pronounced in the upper organic layer than in the deeper organic layer or in the Ah horizon (Butterbach-Bahl \& Papen 2002). Finally, we also found some evidence that anaerobic microsites were created, due to high microbial activity in the uppermost organic layers leading to low methanotrophic activity.

The results of the laboratory incubations of the organic layer samples at the $1000 \mathrm{~m}$ site appear to endorse the widely accepted idea that organic layers consume little, if any, atmospheric $\mathrm{CH}_{4}$ and that most of the $\mathrm{CH}_{4}$ uptake capacity is located in the upper mineral soil (Conrad 1996). However, the results from our incubations of the $2000 \mathrm{~m}$ and $3000 \mathrm{~m}$ organic layers revealed substantial capacity to oxidize atmospheric $\mathrm{CH}_{4}$, with highest methanotrophic activity located in the lowest organic layers right above the mineral soil, which contained mainly strongly decomposed and humified organic matter. As the $\mathrm{CH}_{4}$ concentrations measured in the soil air were below atmospheric, we conclude that this methanotrophic activity was of the high affinity type.

\subsubsection{Conclusions}

Although we found as expected a decrease in $\mathrm{CH}_{4}$ uptake rates with increasing elevation, the widely accepted control mechanisms gas diffusivity, $\mathrm{NH}_{4}{ }^{+}$inhibition and the creation of anaerobic microsites could not or only partly explain variations in atmospheric $\mathrm{CH}_{4}$ uptake of these tropical montane forest soils. In contrast we found some unexpected factors controlling net methane fluxes. Net methane uptake occurred mainly under conditions that are generally favorable for microbial activity, and we found indications that it was $\mathrm{N}$ limited instead of inhibited by $\mathrm{NH}_{4}{ }^{+}$. Finally, we showed that in the thick organic layers substantial high affinity methane oxidation occurred which can influence the $\mathrm{CH}_{4}$ budget of tropical montane forest soils. 


\subsection{References}

Arnold J, Corre MD \& Veldkamp E (2008) Cold storage and laboratory incubation of intact soil cores do not reflect in-situ nitrogen cycling rates of tropical forest soils. Soil Biology \& Biochemistry 40: 2480-2483.

Arnold J, Corre MD \& Veldkamp E (2009) Soil N cycling in old-growth forests across an Andosol toposequence in Ecuador. Forest Ecology and Management 257: 2079-2087.

Blake GR \& Hartge KH (1986) Bulk density. In: Klute A (Ed) Methods of soil analysis, part 1. Physical and mineralogical methods. (p 12). Agronomy Monograph, Soil Science Society of America, Madison, Wisconsin, USA.

Bliese PD \& Ployhart RE (2002) Growth Modeling Using Random Coefficient Models: Model Building, Testing, and Illustrations. Organizational Research Methods 5: 362-387.

Bodelier, P.L.E., Laanbrock, H.J. (2004) Nitrogen as a regulating factor of methane oxidation in soils and sediments. FEMS Microbiology Ecology 47, 265-277.

Brumme R \& Borken W (1999) Site variation in methane oxidation as affected by atmospheric deposition and type of temperate forest ecosystem. Global Biogeochemical Cycles 13: 493501.

Brumme R, Verchot LV, Martikainen PJ \& Potter CS (2005) Contribution of trace gases nitrous oxide (N2O) and methane (CH4) to the atmospheric warming balance of forest biomes. In: Griffiths H \& Jarvis PG (Eds) The carbon balance of forest biomes pp 293-317. Taylor\&Francis Group, Oxon, UK.

Butterbach-Bahl K, Kock, M., Willibald, G., Hewett, B., Buhagiar, S., Papen, H. and Kiese, R. (2004) Temporal variations of fluxes of $\mathrm{NO}, \mathrm{NO} 2, \mathrm{~N} 2 \mathrm{O}, \mathrm{CO} 2$, and $\mathrm{CH} 4$ in a tropical rain forest ecosystem. Global Biogeochemical Cycles 18: GB3012.

Butterbach-Bahl K \& Papen H (2002) Four years continuous record of CH4-exchange between the atmosphere and untreated and limed soil of a N-saturated spruce and beech forest ecosystem in Germany. Plant and Soil 240: 77-90.

Butterbach-Bahl K, Rothe A \& Papen H (2002) Effect of tree distance on N2O and CH4-fluxes from soils in temperate forest ecosystems. Plant and Soil 240: 91-103.

Conrad R (1996) Soil microorganisms as controllers of atmospheric trace gases (H-2, CO, CH4, OCS, N2O, and NO). Microbiological Reviews 60: 609-+.

Crawley MJ (2009) The R book. John Wiley \& Sons Ltd, Chinchester, West Sussex.

Curry CL (2007) Modeling the soil consumption of atmospheric methane at the global scale. Global Biogeochemical Cycles 21: 1-15.

Davidson EA, Ishida FY \& Nepstad DC (2004) Effects of an experimental drought on soil emissions of carbon dioxide, methane, nitrous oxide, and nitric oxide in a moist tropical forest. Global Change Biology 10: 718-730.

Delmas RA, Servant J, Tathy JP, Cros B \& Labat M (1992) Sources and sinks of methane and carbon-dioxide exchanges in mountain forest in Equatorial Africa. Journal of Geophysical Research 97: 6169-6179. 
Dörr H, Katruff L \& Levin I (1993) Soil texture parameterization of the methane uptake in aerated soils. Chemosphere 26: 697-713.

Dutaur L \& Verchot LV (2007) A global inventory of the soil CH4 sink. Global Biogeochemical Cycles 21: 1-9.

Edwards PJ \& Grubb PJ (1977) Studies of mineral cycling in a montane rain-forest in NewGuinea: 1. Distribution of organic-matter in vegetation and soil. Journal of Ecology 65: 943-969.

Emck P (2007) A climatology of south Ecuador - With special focus on the major Andean ridge as Atlantic - Pacific climate divide. Naturwissenschaftliche Fakultäten ( $\mathrm{p}$ 275). FriedrichAlexander-Universität Erlangen-Nürnberg, Erlangen-Nürnberg.

Forster P, V. Ramaswamy, P. Artaxo, T. Berntsen, R. Betts, D.W. Fahey, J. Haywood, J. Lean, D.C. Lowe, G. Myhre, J. Nganga, R. Prinn, G. Raga, M. Schulz \& Dorland RV (2007) Changes in Atmospheric Constituents and in Radiative Forcing. In: Solomon S., D. Qin, M. Manning, Z. Chen, M. Marquis, K.B. Averyt, M.Tignor \& Miller HL (Eds) Climate Change 2007: The Physical Science Basis. Contribution of Working Group I to the Fourth Assessment Report of the Intergovernmental Panel on Climate Change. Cambridge University Press, Cambridge, United Kingdom and New York, NY, USA.

FRA (2000) Global forest recources assessment 2000 - Main report. Food and Agriculture Organization of the United Nations (FAO), Rome.

Guckland A, Flessa H \& Prenzel J (2009) Controls of temporal and spatial variability of methane uptake in soils of a temperate deciduous forest with different abundance of European beech (Fagus sylvatica L.). Soil Biology \& Biochemistry 41: 1659-1667.

Ishizuka S, Iswandi A, Nakajima Y, Yonemura S, Sudo S, Tsuruta H \& Murdiyarso D (2005) The variation of greenhouse gas emissions from soils of various land-use/cover types in Jambi province, Indonesia. Nutrient Cycling in Agroecosystems 71: 17-32.

Keller M \& Reiners WA (1994) Soil atmosphere exchange of nitrous-oxide, nitric-oxide, and methane under secondary succession of pasture to forest in the Atlantic lowlands of CostaRica. Global Biogeochemical Cycles 8: 399-409.

Keller M, Varner R, Dias JD, Silva H, Crill P, de Oliveira Jr. RC \& P. AG (2005) SoilAtmosphere Exchange of Nitrous Oxide, Nitric Oxide, Methane, and Carbon Dioxide in Logged and undisturbed Forest in the Tapajos National Forest, Brazil. Earth Interactions 9: 1-28.

Kiese R, Hewett B, Graham A \& Butterbach-Bahl K (2003) Seasonal variability of N2O emissions and $\mathrm{CH} 4$ uptake by tropical rainforest soils of Queensland, Australia. Global Biogeochemical Cycles 17: 1043.

Kiese R, Wochele S \& Butterbach-Bahl K (2008) Site specific and regional estimates of methane uptake by tropical rainforest soils in north eastern Australia. Plant and Soil 309: 211-226.

Le Mer J \& Roger P (2001) Production, oxidation, emission and consumption of methane by soils: A review. European Journal of Soil Biology 37: 25-50.

Litherland M, Aspen JA \& Jemielita RA (1994) The metamorphic belts of Ecuador-Overseas Geology \& Mineral Resources. British Geological Survey, Keyworth, Nottingham. 
Livingston GP, Hutchinson GL \& Spartalian K (2006) Trace gas emission in chambers: A nonsteady-state diffusion model. Soil Science Society of America Journal 70: 1459-1469.

Loftfield N, Flessa H, Augustin J \& Beese F (1997) Automated gas chromatographic system for rapid analysis of the atmospheric trace gases methane, carbon dioxide, and nitrous oxide. Journal of Environmental Quality 26: 560-564.

Mosier AR \& Delgado JA (1997) Methane and nitrous oxide fluxes in grasslands in western Puerto Rico. Chemosphere 35: 2059-2082.

Piepho HP, Büchse A \& Richter C (2004) A mixed modelling approach for randomized experiments with repeated measures. Journal of Agronomy \& Crop Science 190 230-247

Potter CS, Davidson EA \& Verchot LV (1996) Estimation of global biogeochemical controls and seasonality in soil methane consumption. Chemosphere 32: 2219-2246.

Prather M, Ehhalt D, F. Dentener, R. Derwent, E. Dlugokencky, E. Holland, I. Isaksen, J. Katima, V. Kirchhoff, P. Matson, P. Midgley \& Wang M (2001) Atmospheric Chemistry and Greenhouse Gases. In: Houghton JT, Y. Ding, D.J. Griggs, M. Noguer, P.J. van der Linden, X. Dai, K. Maskell \& Johnson CA (Eds) Climate Change 2001: The Scientific Basis. Contribution of Working Group I to the Third Assessment Report of the Intergovernmental Panel on Climate Change ( $p$ 239). Cambridge University Press, Cambridge.

Purbopuspito J, Veldkamp E, Brumme R \& Murdiyarso D (2006) Trace gas fluxes and nitrogen cycling along an elevation sequence of tropical montane forests in Central Sulawesi, Indonesia. Global Biogeochemical Cycles 20: 11 GB3010.

R Development Core Team (2009) R: A language and environment for statistical computing. Vienna, Austria.

Reiners WA, Keller M \& Gerow KG (1998) Estimating rainy season nitrous oxide and methane fluxes across forest and pasture landscapes in Costa Rica. Water, Air and Soil Pollution 105: 117-130.

Saari A, Heiskanen J \& Martikainen PJ (1998) Effect of the organic horizon on methane oxidation and uptake in soil of a boreal Scots pine forest. Fems Microbiology Ecology 26: 245-255.

Saari A, Martikainen PJ, Ferm A, Ruuskanen J, De Boer W, Troelstra SR \& Laanbroek HJ (1997) Methane oxidation in soil profiles of Dutch and Finnish coniferous forests with different soil texture and atmospheric nitrogen deposition. Soil Biology \& Biochemistry 29: 1625-1632.

Schlichting E, Blume HP \& Stahr K (1995) Bodenkundliches Praktikum. Blackwell Wissenschafts Verlag, Berlin, Wien.

Schnell S \& King GM (1994) Mechanistic analysis of ammonium inhibition of atmospheric methane consumption in forest soils. Applied and Environmental Microbiology 60: 35143521 .

Steinkamp R, Butterbach-Bahl K \& Papen H (2001) Methane oxidation by soils of an N limited and $\mathrm{N}$ fertilized spruce forest in the Black Forest, Germany. Soil Biology \& Biochemistry 33: $145-153$. 
Striegl RG (1993) Diffusional limits to the consumption of atmospheric methane by soils Chemosphere 26: 715-720.

Topp E \& Pattey E (1997) Soils as sources and sinks for atmospheric methane. Canadian Journal of Soil Science 77: 167-178.

Veldkamp E, Purbopuspito J, Corre MD, Brumme R \& Murdiyarso D (2008) Land use change effects on trace gas fluxes in the forest margins of Central Sulawesi, Indonesia. Journal of Geophysical Research-Biogeosciences 113: 11 G02003.

Veldkamp E, Weitz AM \& Keller M (2001) Management effects on methane fluxes in humid tropical pasture soils. Soil Biology \& Biochemistry 33: 1493-1499.

Verchot LV, Davidson EA, Cattanio JH \& Ackerman IL (2000) Land-use change and biogeochemical controls of methane fluxes in soils of eastern Amazonia. Ecosystems 3: 4156.

Wagner SW, Reicosky DC \& Alessi RS (1997) Regression models for calculating gas fluxes measured with a closed chamber. Agronomy Journal 89: 279-284.

Werner C, Zheng XH, Tang JW, Xie BH, Liu CY, Kiese R \& Butterbach-Bahl K (2006) N2O, $\mathrm{CH} 4$ and $\mathrm{CO} 2$ emissions from seasonal tropical rainforests and a rubber plantation in Southwest China. Plant and Soil 289: 335-353. 
76 CHAPTER 3 


\section{CHAPTER \\ 4}

Soil Nutrient AVAIlability AND Belowground CARbon Allocation of Tropical Montane Forests in Southern ECUADOR 
78 CHAPTER 3 


\subsection{Abstract}

Although total belowground carbon allocation (TBCA) accounts for a considerable fraction of carbon assimilated by forest ecosystems, large uncertainties remain about how environmental conditions control the rate of TBCA and the ratio between TBCA and aboveground carbon allocation. The carbon cycle of tropical montane forests has marginally been explored even though montane forests cover about $9 \%$ of the tropical forest area and provide a great opportunity to study TBCA along nutrient, soil moisture and temperature gradients. Here we investigate the influence of nutrient availability and elevation on TBCA in tropical montane forests in southern Ecuador. We estimated TBCA from year-round soil respiration and aboveground litterfall measurements along an elevation gradient from $1000 \mathrm{~m}$ to $3000 \mathrm{~m}$ and from lower slope to ridge positions. Aboveground litter production appeared to be limited by nitrogen $(\mathrm{N})$, potassium $(\mathrm{K})$, and phosphorus $(\mathrm{P})$ and was related mainly to available nutrient stocks of the organic layer, although stocks of $\mathrm{K}$ and $\mathrm{P}$ were larger in the mineral soil. We could not confirm our hypothesis that total and relative TBCA increase when nutrient supply declines. TBCA decreased with elevation and from lower slope toward the ridges and was controlled more by soil moisture and temperatures than available nutrients. The decline in TBCA with increasing elevation corresponded with an increment in fine root biomass which we explain with higher root longevity. Together with slow decomposition rates in the organic layers, this may contribute to the large carbon storage in organic layers of tropical montane forest soils.

\subsection{Introduction}

Total belowground carbon allocation (TBCA) for the production and maintenance of roots and mycorrhiza can make up more than $30 \%$ of the gross primary productivity (Gower et al., 1996; Giardina and Ryan, 2002) and may equal or exceed aboveground C allocation to leaves and aboveground respiration in forest ecosystems (Davidson et al., 2002; Giardina and Ryan, 2002). Long term $C$ sink strength of a forest is determined by net changes in the storage of decay resistant C (Schlesinger and Lichter, 2001), but controls on belowground carbon allocation remain poorly quantified (Davidson et al., 2002; Giardina and Ryan, 2002; Litton et al., 2007).

Despite its importance for the forest carbon cycle, large uncertainties remain, of how 
environmental conditions influence the amount of TBCA and the ratio between TBCA and aboveground C allocation (Raich, 1998). According to allocation theory, plants countervail growth limitations by investing more $\mathrm{C}$ into the components where limitation occurs. If nutrients become a more limiting factor to plant growth than light and $\mathrm{CO}_{2}$, relatively more $\mathrm{C}$ will be invested belowground, into roots (Raich, 1998). A corresponding increase in the ratio of TBCA: aboveground primary productivity (APP) may either be the result of lower aboveground C allocation at constant TBCA (Giardina et al., 2003), of higher root activity at constant APP (Keith et al., 1997a; Litton et al., 2007), or of a combination of both mechanisms (McConnaughay \& Coleman, 1999). Fertilization experiments showed that increased nutrient supply leads to a decline of TBCA (Keith et al., 1997a; Keith et al., 1997b), or left it unchanged (Giardina et al., 2003). On the other hand, there is evidence, that higher nutrient supply may increase TBCA along with GPP (Raich, 1998; Litton et al., 2007; Aragao et al., 2009).

Aboveground primary productivity of tropical montane forests decreases with elevation, which has been related to decreasing temperatures, increasing soil moisture and lower availability of macronutrients such as nitrogen $(\mathrm{N})$, phosphorous $(\mathrm{P})$, and potassium $(\mathrm{K})$ (Bruijnzeel \& Veneklaas, 1998; Tanner et al., 1998). The low nutrient availability is often linked to the occurrence of thick organic layers, and slow mineralization rates of organic matter at higher elevations and on ridge positions (Wilcke et al., 2002; Hertel et al., 2003; Purbopuspito et al., 2006; Arnold et al., 2009). Furthermore $\mathrm{N}$ and $\mathrm{P}$ availability have been found to be depending on soil age, where $\mathrm{N}$ limitation occurs on younger soils as they occur on mountain slopes, whereas P limitation is more pronounced on deeply weathered soils of the lowlands (Walker \& Syers, 1976). Parallel to the decline in APP with elevation, large increases in root biomass have been reported for tropical montane forests (Röderstein et al., 2005; Leuschner et al., 2007; Girardin et al., 2010; Hertel \& Leuschner, 2010). It is however still unclear whether those increases in root biomass are caused by higher fine root productivity and higher TBCA (Röderstein et al., 2005; Leuschner et al., 2007) or by an increase in residence time of the root material with elevation as shown from a study in the Peruvian Andes (Girardin et al., 2010).

Here we investigate how environmental conditions, especially nutrient availability affected TBCA in tropical montane forests of southern Ecuador. We used the indirect C-mass balance approach proposed by Raich \& Nadelhoffer (1989) to estimate TBCA and measured soil 
respiration and aboveground litterfall over one year. We determined TBCA together with availability of N, P and K on 54 plots along an elevation gradient (1000 m to $3000 \mathrm{~m}$ elevation) and topographic gradients covering the three main landscape positions lower slope, midslope and ridge. We tested the hypothesis that absolute and relative belowground carbon allocation (TBCA: aboveground productivity) increases with decreasing nutrient availability along the elevation and topographic gradients.

\subsection{Methods}

\subsubsection{Study area and experimental design}

The study area is located in the Cordillera del Consuelo, which forms part of the eastern chain of the Andes in southern Ecuador. Three study sites were selected along an elevation gradient from $1000 \mathrm{~m}$ to $3000 \mathrm{~m}$ (Table 4.1): 990-1200 m a.s.1. (hereafter called the '1000 m site'), 1800$2100 \mathrm{~m}$ a.s.1. (hereafter called the '2000 m site') and 2800-3000 m a.s.l. (hereafter called the '3000 m site'). At each elevation, we installed 18 plots along a topographic gradient covering the three main landscape positions lower slope, midslope and ridge. Natural vegetation at the $1000 \mathrm{~m}$ site was a premontane rain forest, with Moraceae, Rubiaceae and Melastomataceae being the most important tree families. The $2000 \mathrm{~m}$ site was covered with lower montane rain forest with Lauraceae, Euphorbiaceae, Melastomataceae and Rubiaceae as most important tree families. At $3000 \mathrm{~m}$ natural vegetation was an upper montane rain forest with Cunoniaceae, Clusiaceae and Melastomataceae as most important tree families (Homeier et al., 2008). Along the major environmental gradients (elevation and topography) not only tree species composition, but also forest structure changed. Decreasing stand height and mean diameter at breast height (dbh) and increases in stem density with elevation are typically found with elevation and from the lower slope positions to the ridge positions (Homeier et al., 2010) and (Table 4.1). 
Table 4.1: Site characteristics, forest structure and forest productivity of the topographic positions across the elevation gradient.

\begin{tabular}{|c|c|c|c|c|c|c|c|c|c|}
\hline & \multicolumn{3}{|c|}{$1000 \mathrm{~m}$} & \multicolumn{3}{|c|}{$2000 \mathrm{~m}$} & \multicolumn{3}{|c|}{$3000 \mathrm{~m}$} \\
\hline & Lower slope & Midslope & Ridge & Lower slope & Midslope & Ridge & Lower slope & Midslope & Ridge \\
\hline Coordinates & \multicolumn{3}{|c|}{$04^{\circ} 06^{\prime} \mathrm{S}, 78^{\circ} 58^{\prime} \mathrm{W}$} & \multicolumn{3}{|c|}{$03^{\circ} 58^{\prime} \mathrm{S}, 79^{\circ} 04^{\prime} \mathrm{W}$} & \multicolumn{3}{|c|}{$04^{\circ} 06^{\prime} \mathrm{S}, 79^{\circ} 11^{\prime} \mathrm{W}$} \\
\hline Elevation a.s.1. (m) & \multicolumn{3}{|c|}{$990-1200$} & \multicolumn{3}{|c|}{$1800-2100$} & \multicolumn{3}{|c|}{$2800-3000$} \\
\hline Air temperature $\left({ }^{\circ} \mathrm{C}\right)^{\mathrm{a}}$ & \multicolumn{3}{|c|}{19.4} & \multicolumn{3}{|c|}{15.7} & \multicolumn{3}{|c|}{9.4} \\
\hline Precipitation $\left(\mathrm{mm} \mathrm{yr}^{-1}\right)^{\mathrm{a}}$ & \multicolumn{3}{|c|}{2230} & \multicolumn{3}{|c|}{1950} & \multicolumn{3}{|c|}{4500} \\
\hline Organic layer thickness $(\mathrm{cm})^{b}$ & $2.5(0.7)$ & $2.6(1.0) \mathrm{A}$ & $6.5(1.9) \mathrm{A}$ & $4.0(0.9) \mathrm{a}$ & $12.2(3.1) \mathrm{aB}$ & $24.0(2.9) \mathrm{bB}$ & $6.6(0.7) \mathrm{a}$ & $14.2(1.6) \mathrm{abB}$ & $22.2(3.4) \mathrm{bB}$ \\
\hline Mean dbh $(\geq 10 \mathrm{~cm})^{\mathrm{b}}$ & $22.6(1.4)$ & $22.6(1.9) \mathrm{A}$ & $18.7(1.4) \mathrm{A}$ & $23.8(2.6) \mathrm{a}$ & $19.0(0.6) \mathrm{bAB}$ & $16.8(0.6) \mathrm{bAB}$ & $24.0(1.8) \mathrm{a}$ & $15.9(0.3) \mathrm{bB}$ & $14.7(0.7) \mathrm{bB}$ \\
\hline Stem density $\left(400 \mathrm{~m}^{2}\right)^{\mathrm{b}}$ & $32.8(3.5)$ & $36.0(3.0)$ & $22.6(7.4) \mathrm{A}$ & $30.4(3.6) \mathrm{a}$ & $45.4(2.8) b$ & $45.4(3.6) \mathrm{bAB}$ & $34.4(6.8)$ & $49.3(7.3)$ & $56.7(4.8) \mathrm{B}$ \\
\hline Tree basal area $\left(\mathrm{m}^{2} \mathrm{ha}^{-1}\right)^{\mathrm{b}}$ & $44.8(5.0)$ & $57.2(15.0)$ & $20.3(7.2)$ & $48.9(8.6)$ & $40.4(4.3)$ & $29.2(3.0)$ & $44.8(4.6)$ & $28.1(4.2)$ & $28.6(4.2)$ \\
\hline $\begin{array}{l}\text { Total litter production } \\
\left(\mathrm{Mg} \mathrm{ha}^{-1} \mathrm{yr}^{-1}\right)^{\mathrm{b}}\end{array}$ & $7.0(0.3) \mathrm{aA}$ & $8.6(0.5) \mathrm{bA}$ & $6.4(0.5) \mathrm{aA}$ & $9.5(0.5) \mathrm{aB}$ & $9.8(0.6) \mathrm{aB}$ & $7.1(0.3) \mathrm{bA}$ & $4.7(0.2) \mathrm{C}$ & $4.8(0.5) \mathrm{C}$ & $4.5(0.2) \mathrm{B}$ \\
\hline $\begin{array}{l}\text { Basal area increment } \\
\left(\mathrm{m}^{2} \mathrm{ha}^{-1} \mathrm{yr}^{-1}\right)^{\mathrm{b}}\end{array}$ & $0.6(0.1) \mathrm{AB}$ & $0.8(0.2) \mathrm{A}$ & $0.7(0.2) \mathrm{A}$ & $0.9(0.2) \mathrm{aB}$ & $0.8(0.1) \mathrm{aA}$ & $0.4(0.1) \mathrm{bAB}$ & $0.4(0.03) \mathrm{A}$ & $0.3(0.1) \mathrm{B}$ & $0.3(0.1) \mathrm{B}$ \\
\hline
\end{tabular}

${ }^{\mathrm{a}}$ Moser et al. (2007)

${ }^{\mathrm{b}}$ Means $( \pm \mathrm{SE}, \mathrm{n}=6)$ within rows followed by different letter indicate significant differences among topographic positions at each elevation (small letters) and differences among elevations at each topographic position (capital letters) (two-way ANOVA with Fischer LSD test at $P \leq 0.05$ ). 
For most of the study area, Paleozoic metamorphic schist and sandstone with some quartz veins form the parent material for soil development. Only at the $1000 \mathrm{~m}$ site soil parent material of half of the plots consists of deeply weathered granitic rock of the Jurassic Zamora granitoide formation (Litherland et al., 1994). Organic layer thickness increased with elevation and from lower slope positions to ridge positions (Table 4.1). At the ridge positions of the $2000 \mathrm{~m}$ and $3000 \mathrm{~m}$ sites and to some extend at the ridges of the $1000 \mathrm{~m}$ site, soils displayed Humic and Histic characteristics (thick organic layers). Soils at well-drained positions of the $1000 \mathrm{~m}$ and $2000 \mathrm{~m}$ sites were Eutric or Dystric Cambisols. Soils with hydromorphic properties (Stagnic Cambisols or Planosols) were found on the ridges of the $2000 \mathrm{~m}$ site and at all topographic positions of the $3000 \mathrm{~m}$ site (Chapter 2.4.1).

\subsubsection{Experimental Design}

At each elevation we established 18 plots, six at each landscape position (lower slope, midslope and ridge positions). All plots were situated in mature, closed-canopy forest that was representative of the respective topographic position. At each plot we installed four chamber bases for gas exchange measurements and six litter traps in a stratified random design along two orthogonal transects.

\subsubsection{Total and available soil nutrients}

We determined total and available phosphorus $\left(\mathrm{P}_{\text {tot }}\right.$ and $\left.\mathrm{P}_{\mathrm{av}}\right)$ and total potassium $\left(\mathrm{K}_{\text {tot }}\right)$ on composite soil samples consisting of four subsamples per plot taken with an auger within onemeter distance of the chamber bases. Depending on the depth of the organic layer, we took one or two depths from the organic layer $(0-10 \mathrm{~cm}$ and if present also $10-20 \mathrm{~cm} \mathrm{depth})$ and two depths of the mineral soil $\left(0-10 \mathrm{~cm}\right.$ and $10-20 \mathrm{~cm}$ depth). Available potassium $\left(\mathrm{K}_{\mathrm{av}}\right)$ of the mineral soil and total soil nitrogen $(\mathrm{N})$ were assessed from soil samples taken by horizon from soil profiles situated at the outer border of the plots. All soil samples were dried at $45{ }^{\circ} \mathrm{C}$ for three days, sieved and stored in plastic bags until analysis in Germany. Analysis of soil $\mathrm{P}_{\text {tot }}$ and $\mathrm{K}_{\text {tot }}$ concentrations was done using Inductively Coupled Plasma-Atomic Emission Spectrometer (ICP-AES, Spectro Analytical Instruments, Kleve, Germany) after pressure digestion in 65\% $\mathrm{HNO}_{3}$ (Heinrichs et al., 1986). We determined $\mathrm{P}_{\mathrm{av}}$ using the modified Hedley fractionation 
method (Tiessen \& Moir, 1993), extracting $0.5 \mathrm{~g}$ of soil succeeding with an anion exchange resin and $0.5 \mathrm{M}$ sodium bicarbonate $\left(\mathrm{NaHCO}_{3}\right)$. Instead of the membrane shaped anion exchange resin used by Thiessen and Moir (1993) we used one gram (moist weight) of pellet-shaped anion exchange resin (DOVEX ${ }^{\circledR}$ 1x8 20-50 mesh, SERVA Electrophoresis GmbH, Heidelberg, Germany), which was sewed into a polyester gauze bag (Wullfen, 1989). Phosphorus concentration in the fractions was measured using ICP-AES. Based on Cross and Schlesinger (1995) we defined plant-available $\mathrm{P}$ as the sum of $\mathrm{P}$ in the resin and $\mathrm{NaHCO}_{3}$ fractions. We obtained $\mathrm{K}_{\mathrm{av}}$ from the determination of the exchangeable cations from sieved soil samples by measuring $\mathrm{K}$ concentration in percolates of soils with unbuffered $1 \mathrm{M} \mathrm{NH}_{4} \mathrm{Cl}$ using ICP-AES (König \& Fortmann, 1996). Total carbon $\left(\mathrm{C}_{\text {tot }}\right)$ and total nitrogen $\left(\mathrm{N}_{\text {tot }}\right)$ were determined using a CNS Elemental Analyzer (Elementar Vario EL, Hanau, Germany). Nutrient stocks were calculated under consideration of bulk density, which was determined for mineral soil using steel cores $\left(250 \mathrm{~cm}^{3}\right)$ and for the organic layer by measuring the thickness and dry weight of an area of $400 \mathrm{~cm}^{2}$ (Blake \& Hartge, 1986; Schlichting \& Stahr., 1995).

\subsubsection{Soil respiration}

We measured soil respiration bi-monthly over a period of one year (May 2008 - May 2009) using static closed chambers with a base area of $0.044 \mathrm{~m}^{2}$ and a closed chamber volume of 13 liters. Chamber bases were installed six months prior to the first measurement, by inserting them approximately $0.02 \mathrm{~m}$ into the soil, and remained in place until the end of the sampling period. Chamber lids were equipped with a Luer-Lock sampling port and a vent for pressure equilibration. Gas samples were taken 2, 14, 26, and 38 minutes following chamber closure using pre-evacuated glass containers $(60 \mathrm{ml})$. Pressure was checked with a manometer during sampling to assure that containers had been evacuated properly and were filled to atmospheric pressure. Soil temperature and gravimetric soil moisture were determined concomitantly to every soil respiration measurement. Gas samples were analyzed within 48 hours following sampling using a gas chromatograph (Shimadzu GC-14B, Duisburg, Germany) equipped with an electron capture detector (ECD) combined with an autosampler (Loftfield et al., 1997). Gas concentrations were calculated by comparing integrated peak areas of samples with four standard gases $\left(350,700,1500,5000 \mu \mathrm{L} \mathrm{L}^{-1}\right.$ standard concentrations of $\mathrm{CO}_{2}$; Deuste Steiniger $\mathrm{GmbH}$, Mühlhausen, Germany). $\mathrm{CO}_{2}$ emissions were calculated by fitting both linear and quadratic 
regression models if $\mathrm{CO}_{2}$ concentrations increased asymptotically (Wagner et al., 1997). Based on the Akaike Information Criterion the quadratic model was found to be statistically more adequate and therefore applied in about $50 \%$ of the cases. By applying this data screening and model fitting, we minimized underestimations of $\mathrm{CO}_{2}$ emissions that may have occurred by using linear models uncritically with static chamber flux data (e.g. Livingston et al., 2006). Volumetric gas fluxes were converted to mass fluxes by multiplying net gas fluxes by the density of air and the ratio of chamber volume to soil surface area (Köhler et al., 2009b). Annual fluxes were calculated from the average of the bi-monthly measurements.

\subsubsection{Aboveground productivity and litter quality}

Aboveground productivity was estimated by summing up fine litter production (litter $<2 \mathrm{~cm}$ ) and aboveground wood increment both expressed in $\mathrm{kg} \mathrm{C} \mathrm{h}^{-1} \mathrm{yr}^{-1}$. Total litter was collected monthly (bi-weekly at $1000 \mathrm{~m})$ from six litter traps $(60 \times 60 \mathrm{~cm})$ per plot. Total litter, including leaves, twigs, epiphytes, flowers and fruits, was dried at $60^{\circ} \mathrm{C}$ and weighed. Aboveground litterfall $\mathrm{C}$ input was calculated by multiplying $\mathrm{C}$ concentrations of the litter and total annual litter fall for each plot. Wood increment was determined by measurement of tree basal area increment of all trees with a diameter $>10 \mathrm{~cm}$ over one year and by measuring wood density using an Pilodyn 6J wood tester (PROCEQ SA, Zürich, Switzerland) as suggested by Chave et al. (2008). Aboveground biomass was estimated according to models provided by Chave et al. (2005) applying the moist forest category model for the $1000 \mathrm{~m}$ and $2000 \mathrm{~m}$ sites and the wet forest category model at the $3000 \mathrm{~m}$ site. C content of the wood was estimated to be $50 \%$ (Link, 2010). Total litterfall of December 2008 was collected, ground and sent to Germany for analysis. Litter samples of the six litter traps were proportionally pooled for each plot. Carbon and $\mathrm{N}$ concentrations were determined using a CNS Elemental Analyzer (Elementar Vario EL, Hanau, Germany). Total $\mathrm{P}$ and $\mathrm{K}$ concentrations in litter were measured using ICP-AES after pressure digestion as described for soil samples. Additionally we used soil $\mathrm{C}: \mathrm{N}, \mathrm{C}: \mathrm{P}$ and $\mathrm{C}: \mathrm{K}$ ratios as an index for nutrient availability. 


\subsubsection{Total belowground carbon allocation}

Total belowground carbon allocation (TBCA) is all carbon transferred belowground for belowground productivity (root building, root exudates, root and mycorrhiza mortality) and root respiration. We estimated TBCA using the C-mass balance approach proposed by Raich and Nadelhoffer (1989).

$$
\mathrm{TBCA}=\mathrm{R} \text { soil }- \text { aboveground litterfall } \mathrm{C} \text {, }
$$

Where $\mathrm{R}$ soil is soil respiration $\left(\mathrm{CO}_{2}\right.$ emissions from the soil), which consists of heterogenic respiration (decomposition by microbes) and root respiration. Aboveground litterfall $\mathrm{C}$ is the carbon input via litterfall (Raich and Nadelhoffer, 1989; Davidson et al., 2002). This approach may only be used under the assumption that soils are in steady state with respect to total organic carbon storage, because only then annual inputs of detritus from above and belowground are approximately equal to annual respiration of decomposers within the soil. Other fluxes into or out of the soil (dry and wet precipitation, leaching, runoff, erosion) are minor in comparison to the major fluxes and thus have little influence on the carbon budget (Raich and Nadelhoffer, 1989). Davidson et al. (2002) suppose that soil C stocks in forest stands that have not undergone major disturbance during the last several decades are likely approaching a steady state. As our plots are situated under mature forest without natural gaps or signs of anthropogenic disturbance, we assume that the forest sites of our study are in a steady state.

\subsubsection{Statistical analysis}

For testing elevation and topography effects on annual $\mathrm{C}$ fluxes and data that were measured once (i.e. soil characteristics) we used two-way analysis of variance (two-way ANOVA). Data were tested for normality and heteroscedasticity and transformed if necessary. For multiple comparisons after ANOVA we applied the Tukey HSD test. The relationships among soil characteristics and annual $\mathrm{C}$ fluxes were assessed by linear and non-linear regression (2parameter exponential asymptotic regression, yield function after Mitscherlich: $\mathrm{y}=\mathrm{a} *(1-$ $\exp (-b * x)))$. Regressions were carried out on the means of six plots for each topographic position at the $2000 \mathrm{~m}$ and the $3000 \mathrm{~m}$ site and separate for the two different geological substrates at the $1000 \mathrm{~m}$ site $(\mathrm{n}=12 ; 3$ topographic positions of 2 elevations and 3 topographic 
positions of two substrates at one elevation). Linear and non-linear regression were used because linear mixes effects models (LME) and non-linear mixed effects models (NLME) did not improve the fit of the models on the 12-point database. The effects of geological substrate on nutrient concentrations and annual $\mathrm{C}$ fluxes were assessed using one-way ANOVA. Linear mixed effects models were applied to test the effect of soil depth on the amount of total and available nutrients, including topographic positions nested into the elevations as spatial random factor. We used LME to account for the hierarchical study design by including different error variances of the different spatial scales (Crawley 2009). Linear mixed effects models were tested for autocorrelation effects by including a first order autoregressive structure and for heteroscedasticity of residual variance by including variance functions (Bliese \& Ployhart, 2002). Model residuals were tested for normal distribution, and data were transformed if necessary.

\subsection{Results}

\subsubsection{Soil total and available nutrients}

Soil depths had a strong influence on total and available nutrient stocks at all elevations and topographic positions $(\mathrm{P}<0.001)$. Generally total and available nutrient stocks were lower in the organic layer compared to the mineral soil $(\mathrm{P}<0.001$; Table 4.2$)$. We found no differences of nutrient concentrations between the two depths of the organic layer (where present), therefore we used data from the upper organic layer $(0-10 \mathrm{~cm})$ for further investigation. Stocks of $\mathrm{P}_{\mathrm{av}}, \mathrm{P}_{\mathrm{tot}}$ and $\mathrm{K}_{\text {tot }}$ within the organic layer were not different between the geological substrates of the $1000 \mathrm{~m}$ site. At both mineral soil depths $(0-10 \mathrm{~cm}$ and $10-20 \mathrm{~cm}) \mathrm{P}_{\text {tot }}$ and $\mathrm{K}_{\text {tot }}$ stocks of the schist material were higher $(\mathrm{P} \leq 0.01)$ than of the granite material (Table 4.4). Soil $\mathrm{P}_{\mathrm{av}}$ and $\mathrm{K}_{\mathrm{av}}$ stocks of the schist material were only higher in the deeper mineral soil $\left(\mathrm{P}=0.03\right.$ for $\mathrm{P}_{\mathrm{av}}$ and $\mathrm{P}=0.05$ for $\left.\mathrm{K}_{\mathrm{av}}\right)$ (Table 4.4). Total $\mathrm{P}, \mathrm{P}_{\mathrm{av}}$ and $\mathrm{K}_{\text {tot }}$ stocks were influenced by elevation at all three soil depths ( $\mathrm{P} \leq 0.01)$, with highest $\mathrm{P}$ and $\mathrm{K}$ stocks at the $2000 \mathrm{~m}$ site and lowest values at the $3000 \mathrm{~m}$ site. Available K of the two mineral soil depths did not change with elevation (Table 4.2). Available and total nutrient stocks on granite at the $1000 \mathrm{~m}$ site did not differ between topographic positions in neither of the soil depth, whereas on schist $\mathrm{P}_{\text {tot }}, \mathrm{P}_{\mathrm{av}}, \mathrm{K}_{\mathrm{tot}}$, and $\mathrm{K}_{\mathrm{av}}$ stocks at both 
mineral soil depths were highest at the midslope position (Table 4.4). At $2000 \mathrm{~m}$ and $3000 \mathrm{~m}$ soil $\mathrm{P}_{\text {tot }}$ and $\mathrm{P}_{\mathrm{av}}$ were influenced by the topographic position $(\mathrm{P} \leq 0.05)$ with decreasing nutrient contents toward the ridges at all soil depths (Table 4.2). Soil $\mathrm{K}_{\text {tot }}$ stocks at all soil depths at 2000 $\mathrm{m}$ were highest at the lower slope positions, whereas soil $\mathrm{K}_{\mathrm{av}}$ stocks did not change between the topographic positions at $2000 \mathrm{~m}$ and $3000 \mathrm{~m}$ (Table 4.4).

Different geological substrate at the $1000 \mathrm{~m}$ site did not affect $\mathrm{C}: \mathrm{N}$ ratios of the organic layer and the two mineral soil depths. $\mathrm{C}: \mathrm{N}$ ratios of the organic layer and the two mineral soil depths were affected by elevation as well as topography with increasing ratios with elevation ( $\mathrm{P}<0.001$ for elevation and topography effect on $\mathrm{C}: \mathrm{N}$ ratio of all three soil depths, Table 4.2). At the $1000 \mathrm{~m}$ site $\mathrm{C}: \mathrm{N}$ ratios of the organic layer were not different between topographic positions at neither of the geological substrates, whereas both mineral soil depths on granite and the 10-20-cm soil depth on schist showed highest C:N ratios at the ridge positions. At the 2000 and $3000 \mathrm{~m}$ site $\mathrm{C}: \mathrm{N}$ ratios of all three soil depths increased toward the ridges. The lower slope and midslope positions at the $2000 \mathrm{~m}$ site showed lowest $\mathrm{C}: \mathrm{N}$ ratios at all soil depths (Table 4.2).

Organic layer thickness did not correlate with total or available $\mathrm{K}$ and $\mathrm{P}$ stocks at any of the soil depths and showed only weak correlation with the $\mathrm{C}: \mathrm{N}$ ratio of the organic layer $(\mathrm{P}=0.003$, $\mathrm{R}^{2}=0.31$, data not shown). 
Table 4.2: Nutrient input, C:nutrient ratios in aboveground litterfall and C:N ratios, available and total phosphorus (P) and potassium (K) stocks at different soil depths and of the topographic positions along the elevation gradient.

\begin{tabular}{|c|c|c|c|c|c|c|c|c|c|}
\hline & \multicolumn{3}{|c|}{$1000 \mathrm{~m}$} & \multicolumn{3}{|c|}{$2000 \mathrm{~m}$} & \multicolumn{3}{|c|}{$3000 \mathrm{~m}$} \\
\hline & Lower Slope & Midslope & Ridge & Lower Slope & Midslope & Ridge & Lower Slope & Midslope & Ridge \\
\hline \multicolumn{10}{|l|}{ Litterfall } \\
\hline $\mathrm{C}: \mathrm{N}$ & $31.6(0.9) \mathrm{A}$ & $32.6(2.1) \mathrm{A}$ & $35.8(2.4) \mathrm{A}$ & $24.8(2.4) \mathrm{aA}$ & $27.0(2.2) \mathrm{aA}$ & $39.6(2.2) \mathrm{bA}$ & $43.8(1.8) \mathrm{aB}$ & $55.5(5.0) \mathrm{bB}$ & $77.9(3.1) \mathrm{cB}$ \\
\hline $\mathrm{C}: \mathrm{K}$ & $83.8(4.8) \mathrm{A}$ & $81.1(2.8) \mathrm{A}$ & $88.8(10.2) \mathrm{A}$ & $70.6(3.7) \mathrm{aA}$ & $100.3(17.1) \mathrm{aB}$ & $140.9(10.2) \mathrm{bB}$ & $161.2(12.5) \mathrm{B}$ & $182.0(17.4) \mathrm{B}$ & $198.5(8.1) \mathrm{C}$ \\
\hline $\mathrm{C}: \mathrm{P}$ & $713.4(46.0) \mathrm{A}$ & $683.9(43.8) \mathrm{A}$ & 843.6 (72.7)A & $408.5(58.5) \mathrm{aB}$ & $499.2(85.8) \mathrm{aA}$ & $906.0(66.2) \mathrm{bA}$ & $901.0(58.0) \mathrm{aB}$ & $1403.4(94.9) \mathrm{bB}$ & $1820.6(183.8) b B$ \\
\hline $\begin{array}{l}\text { Aboveground litterfall } 1 \\
\mathrm{~N}\left(\mathrm{~kg} \mathrm{ha}^{-1} \mathrm{yr}^{-1}\right)\end{array}$ & $1116.4(7.7) \mathrm{A}$ & $136.6(7.9) \mathrm{A}$ & $100.6(6.6) \mathrm{A}$ & $196.78(14.4) \mathrm{aB}$ & $191.7(21.7) a B$ & $97.4(6.1) \mathrm{bA}$ & $56.7(3.3) \mathrm{aC}$ & $46.9(4.8) \mathrm{aC}$ & $31.8(2.2) \mathrm{bB}$ \\
\hline $\begin{array}{l}\text { Aboveground litterfall } \\
\mathrm{K}\left(\mathrm{kg} \mathrm{ha}^{-1} \mathrm{yr}^{-1}\right)\end{array}$ & $3.4(0.2) \mathrm{A}$ & $3.4(0.1) \mathrm{A}$ & $3.3(0.3) \mathrm{A}$ & $3.6(0.2) \mathrm{aA}$ & $3.0(0.5) \mathrm{abA}$ & $2.1(0.2) \mathrm{bB}$ & $1.7(0.1) \mathrm{B}$ & $1.6(0.2) \mathrm{B}$ & $1.5(0.1) \mathrm{B}$ \\
\hline $\begin{array}{l}\text { Aboveground litterfall } \\
\mathrm{P}\left(\mathrm{kg} \mathrm{ha}^{-1} \mathrm{yr}^{-1}\right)\end{array}$ & $5.9(0.5) \mathrm{A}$ & $7.0(0.9) \mathrm{AB}$ & $4.6(0.2) \mathrm{A}$ & $12.3(1.0) \mathrm{aB}$ & $11.9(2.5) \mathrm{aA}$ & $4.3(0.4) \mathrm{bA}$ & $2.8(0.2) \mathrm{aC}$ & $1.8(0.2) \mathrm{bB}$ & $1.5(0.3) \mathrm{bB}$ \\
\hline \multicolumn{10}{|l|}{ Organic Layer } \\
\hline $\mathrm{P}_{\text {tot }}\left(\mathrm{kg} \mathrm{ha}^{-1}\right)$ & $51.6(19.0) \mathrm{AB}$ & 61.3 (13.4)A & $52.9(25.7) \mathrm{A}$ & $91.8(19.8) \mathrm{aA}$ & $70.3(26.5) \mathrm{aA}$ & $16.9(1.3) \mathrm{bAB}$ & $24.5(2.6) \mathrm{aB}$ & $15.1(1.4) \mathrm{aB}$ & $10.9(1.2) \mathrm{bB}$ \\
\hline $\mathrm{P}_{\text {av }}\left(\mathrm{kg} \mathrm{ha}^{-1}\right)$ & $7.5(3.4) \mathrm{A}$ & $10.7(3.0)$ & $8.96(3.3)$ & $21.3(4.5) \mathrm{aB}$ & $12.5(4.9) \mathrm{ab}$ & $5.2(0.6) \mathrm{b}$ & $8.0(1.0) \mathrm{aAB}$ & $5.1(0.6) \mathrm{b}$ & $3.6(0.3) \mathrm{b}$ \\
\hline $\mathrm{K}_{\text {tot }}\left(\mathrm{kg} \mathrm{ha}^{-1}\right)$ & $403.9(180.7) \mathrm{AB}$ & $299.9(96.8) \mathrm{A}$ & $344.4(228.8)$ & $708.5(206.7) \mathrm{aA}$ & $257.6(53.6) \mathrm{aA}$ & $46.9(6.9) b$ & 104.5 (19.7)B & $70.4(7.0) \mathrm{B}$ & $80.1(22.9)$ \\
\hline $\mathrm{C}: \mathrm{N}$ & $18.5(0.7) \mathrm{A}$ & $18.6(1.5) \mathrm{A}$ & $20.5(0.7) \mathrm{A}$ & $15.7(0.8) \mathrm{aB}$ & $15.6(0.6) \mathrm{aA}$ & $21.1(0.7) \mathrm{bA}$ & $20.5(0.8) \mathrm{aA}$ & $23.9(1.4) b B$ & $26.7(1.3) \mathrm{cB}$ \\
\hline \multicolumn{10}{|l|}{ Mineral Soil (0-10cm) } \\
\hline$P_{\text {tot }}\left(\mathrm{kg} \mathrm{ha}^{-1}\right)$ & $167.8(38.0) \mathrm{A}$ & 349.5 (225.8)A & $127.6(15.9) \mathrm{A}$ & $350.8(37.2) \mathrm{aB}$ & $241.3(47.7) \mathrm{aA}$ & $89.2(12.3) \mathrm{bA}$ & $85.7(5.7) \mathrm{aA}$ & $62.6(12.6) \mathrm{abB}$ & $40.8(7.1) \mathrm{bB}$ \\
\hline $\mathrm{P}_{\text {av }}\left(\mathrm{kg} \mathrm{ha}^{-1}\right)$ & $11.5(2.0) \mathrm{A}$ & $23.5(11.1)$ & $10.2(0.9)$ & $41.7(7.4) \mathrm{aB}$ & $34.6(7.1) \mathrm{ab}$ & $17.3(5.2) \mathrm{b}$ & $31.0(8.2) \mathrm{aB}$ & $14.9(3.0) \mathrm{ab}$ & $11.6(2.0) \mathrm{b}$ \\
\hline $\mathrm{K}_{\text {tot }}\left(\mathrm{Mg} \mathrm{ha}^{-1}\right)$ & $2.1(0.6) \mathrm{A}$ & $3.2(1,7)$ & $1.6(0.5) \mathrm{A}$ & $11.1(2.2) \mathrm{aB}$ & $3.5(0.9) \mathrm{b}$ & $5.4(1.2) \mathrm{abB}$ & $2.1(0.3) \mathrm{A}$ & $2.8(0.6)$ & $1.9(0.4) \mathrm{A}$ \\
\hline $\mathrm{K}_{\mathrm{av}}{ }^{\mathrm{b}}\left(\mathrm{kg} \mathrm{ha}^{-1}\right)$ & $40.6(11.8)$ & $63.5(6.8)$ & $9.3(1.4)$ & $25.5(6.3)$ & $22.8(11.3)$ & $16.5(2.1)$ & $27.6(3.6)$ & $28.4(6.1)$ & $29.7(3.5)$ \\
\hline $\mathrm{C}: \mathrm{N}$ & $16.3(0.6) \mathrm{aA}$ & $15.0(0.7) \mathrm{a}$ & $21.3(1.2) \mathrm{bB}$ & $13.2(1.1) \mathrm{B}$ & $14.1(1.5)$ & $17.0(0.8) \mathrm{A}$ & $14.2(0.2) \mathrm{aAB}$ & $18.0(1.1) \mathrm{b}$ & $22.3(1.0) \mathrm{cB}$ \\
\hline \multicolumn{10}{|l|}{ Mineral soil $(10-20 \mathrm{~cm})$} \\
\hline$P_{\text {tot }}\left(\mathrm{kg} \mathrm{ha}^{-1}\right)$ & $187.4(75.6)$ & $331.9(223.0) \mathrm{A}$ & $116.6(18.8) \mathrm{A}$ & $300.1(26.5) \mathrm{a}$ & $244.8(56.9) \mathrm{aAB}$ & $89.9(15.6) \mathrm{bAB}$ & $103.0(12.3) \mathrm{a}$ & $57.3(11.0) \mathrm{abB}$ & $54.9(11.3) \mathrm{bB}$ \\
\hline $\mathrm{P}_{\mathrm{av}}\left(\mathrm{kg} \mathrm{ha}^{-1}\right)$ & $19.0(10.7)$ & 17.6 (6.9)AB & $8.5(1.4)$ & $33.8(5.7) \mathrm{a}$ & $33.7(6.1) \mathrm{aA}$ & $10.2(2.8) \mathrm{b}$ & $25.1(2.8) \mathrm{a}$ & 7.3 (1.6)bB & $11.1(2.3) \mathrm{b}$ \\
\hline $\mathrm{K}_{\text {tot }}\left(\mathrm{Mg} \mathrm{ha}^{-1}\right)$ & $3.1(0.9) \mathrm{A}$ & $3.4(1.8)$ & $2.0(0.7) \mathrm{A}$ & $11.2(1.8) \mathrm{aB}$ & $3.7(1.1) \mathrm{b}$ & 6.7 (1.4)abB & $3.2(0.3) \mathrm{A}$ & $3.7(0.9)$ & $3.8(0.5) \mathrm{AB}$ \\
\hline $\mathrm{K}_{\mathrm{av}}^{\mathrm{b}}\left(\mathrm{kg} \mathrm{ha}^{-1}\right)$ & $29.3(7.7)$ & 13.7 (NA) & $5.8(0.2)$ & $18.5(4.8)$ & $14.2(6.7)$ & $8.4(1.1)$ & $23.5(7.3)$ & $10.2(4.3)$ & $16.6(2.8)$ \\
\hline $\mathrm{C}: \mathrm{N}$ & $14.1(0.8) \mathrm{aA}$ & $13.2(1.9) \mathrm{a}$ & $21.5(1.2) \mathrm{bA}$ & $8.5(1.8) \mathrm{B}$ & $13.1(1.7)$ & $14.3(1.5) \mathrm{B}$ & $14.5(0.8) \mathrm{aA}$ & $17.2(0.7) \mathrm{a}$ & $21.6(1.5) \mathrm{bA}$ \\
\hline
\end{tabular}

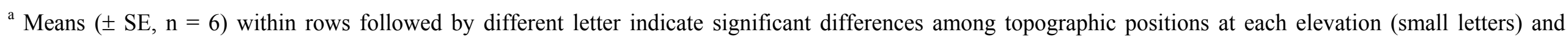
differences among elevations at each topographic position (capital letters) (two-way ANOVA with Tukey HSD test at $P \leq 0.05$ ).

${ }^{\mathrm{b}} \mathrm{K}_{\mathrm{av}}$ determination using the $\mathrm{NaHCO}_{3}$ extracts of the Hedley fractionation

${ }^{\mathrm{c}} \mathrm{K}_{\mathrm{av}}$ determination via measurement of cation exchange capacity from soil profiles 


\subsubsection{Litter quality}

Total nutrient content in aboveground litterfall $\left(\mathrm{kg} \mathrm{ha}^{-1} \mathrm{yr}^{-1}\right)$ was influenced by elevation and topography $(\mathrm{P}<0.001$ for the elevation effect and $\mathrm{P} \leq 0.02$ for the topographic effect on $\mathrm{K}, \mathrm{P}$ and $\mathrm{N}$ content in aboveground litterfall). Nutrient input via litterfall was highest at the lower and midslope positions of the $2000 \mathrm{~m}$ site and was generally lowest at the ridge positions at all elevations. Phosphorous concentration of aboveground litterfall was linearly correlated with $\mathrm{P}_{\text {tot }}$ stocks of the organic layer $\left(\mathrm{P}=0.001, \mathrm{R}^{2}=0.63\right.$, Figure 4.1 a) and followed a saturation function with $\mathrm{P}_{\text {tot }}$ concentrations of the two mineral soil depths $\left(\mathrm{P}<0.001, \mathrm{R}^{2} \leq 0.71\right)$. Potassium concentration of aboveground litterfall followed a saturation function with $\mathrm{K}_{\text {tot }}$ stocks of the organic layer $\left(\mathrm{P}<0.01, \mathrm{R}^{2}\right.$ $=0.59$, Figure 4.1 b) but did not correlate with $\mathrm{K}_{\mathrm{av}}$ at the mineral soil depths. Soil $\mathrm{P}_{\mathrm{av}}$ content at all soil depths correlated linearly with $\mathrm{P}$ concentration in aboveground litterfall with weaker relationships for $\mathrm{P}_{\mathrm{av}}$ in the mineral soil compared to the organic layer $\left(\mathrm{P}<0.01, \mathrm{R}^{2}=0.80\right.$ in the organic layer, Figure $4.1 \mathrm{c} ; \mathrm{P}=0.04, \mathrm{R}^{2}=0.30$ at $0-10 \mathrm{~cm}, \mathrm{P}<0.01, \mathrm{R}^{2}=0.60$ at $10-20 \mathrm{~cm}$ depth, data not shown). Nitrogen concentration in aboveground litterfall was closely correlated to the $\mathrm{C}: \mathrm{N}$ ratio, and thus $\mathrm{N}$ availability of the organic layer (Figure $4.1 \mathrm{~d}, \mathrm{P}<0.001, \mathrm{R}^{2}=0.91$ ).

At the 1000 m site carbon: nutrient ratios in litterfall $(\mathrm{C}: \mathrm{N}, \mathrm{C}: \mathrm{K}$ and $\mathrm{C}: \mathrm{P})$ were generally lower in plots over schist material than over granite . Litterfall C:nutrient ratios were influenced by elevation and topography $(\mathrm{P}<0.001$ for elevation and topography effect on $\mathrm{C}: \mathrm{N}, \mathrm{C}: \mathrm{K}$ and $\mathrm{C}: \mathrm{P}$ ratios in aboveground litterfall). They were lowest at the lower slope and midslope positions of the $2000 \mathrm{~m}$ site and increased toward the ridges at the $2000 \mathrm{~m}$ and the $3000 \mathrm{~m}$ sites (Table 4.2). We found no difference in $\mathrm{C}: \mathrm{N}, \mathrm{C}: \mathrm{K}$ and $\mathrm{C}: \mathrm{P}$ ratios between topographic positions at the $1000 \mathrm{~m}$ site (schist and granite). Carbon:nutrient concentration in aboveground litterfall showed best relations with the available and total nutrient stocks in the organic layer. Aboveground litterfall $\mathrm{C}: \mathrm{K}$ ratio correlated positively with the $\mathrm{K}_{\text {tot }}$ stocks of the mineral soil $\left(\mathrm{P}=0.02, \mathrm{R}^{2}=0.30\right.$ for $\mathrm{K}_{\mathrm{av}}$, and $\mathrm{P}=0.02, \mathrm{R}^{2}=0.39$ for $\left.\mathrm{K}_{\mathrm{tot}}\right)$. C:P ratio of the aboveground litterfall showed linear correlations with the organic layer stocks of $\mathrm{P}_{\mathrm{av}}$ and $\mathrm{P}_{\text {tot }}\left(\mathrm{P}=0.01, \mathrm{R}^{2}=0.46\right.$ for $\mathrm{P}_{\mathrm{av}}$ and $\mathrm{P}=0.01, \mathrm{R}^{2}=0.46$ for $\left.\mathrm{P}_{\text {tot }}\right)$, whereas it followed exponential decay functions with $\mathrm{P}_{\text {tot }}$ content of the two mineral soil depths $\left(\mathrm{P}<0.001, \mathrm{R}^{2}=0.88\right.$ for $0-10 \mathrm{~cm}$ depth and $\mathrm{P}<0.001, \mathrm{R}^{2}=0.88$ for $10-20 \mathrm{~cm}$ depth). We found very close linear correlations between $\mathrm{C}: \mathrm{N}$ ratios of the aboveground litterfall and the $\mathrm{C}: \mathrm{N}$ ratio of the organic layer $(\mathrm{P}<0.001$, 
$\left.\mathrm{R}^{2}=0.84\right)$ and weaker linear correlations with $\mathrm{C}: \mathrm{N}$ ratios of the mineral soil $\left(\mathrm{P} \leq 0.04, \mathrm{R}^{2}=0.30\right.$ for both mineral soil depths).
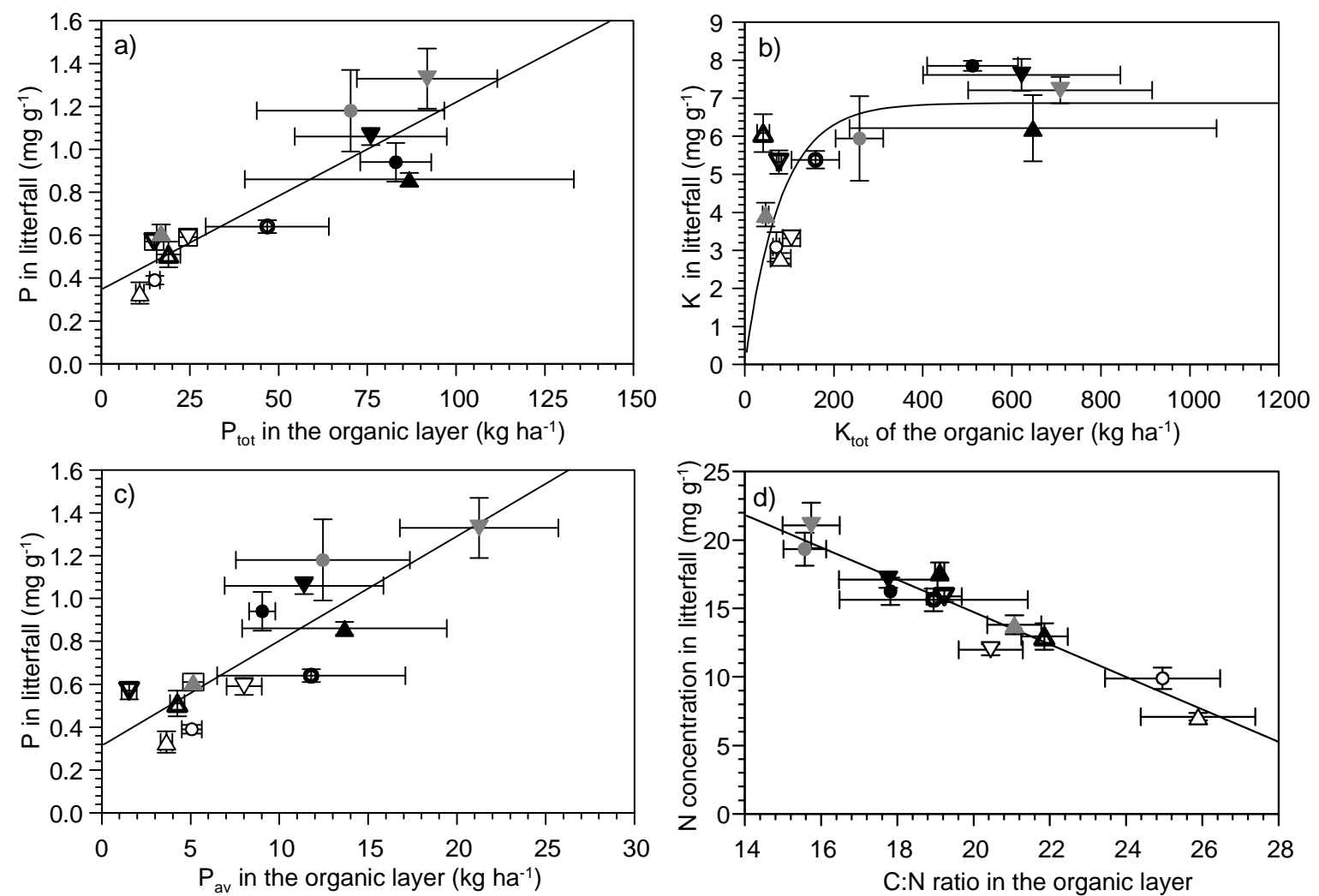

Figure 4.1: Relationship between litterfall nutrient concentration and total and available nutrient stocks of the organic layer (means \pm standard error), with a) total phosphorus $(Y=0.35+0.01 * x, P<0.01$, $\left.\left.R^{2}=0.79\right), b\right)$ total potassium $\left(Y=a *(1-\exp (-b * x)), a=6.9 \pm 0.5, b=0.01 \pm 0.003, P<0.01, R^{2}=0.87\right)$ c) available phosphorus $\left.\left(Y=0.31+0.05 * x, P<0.01, R^{2}=0.70\right), d\right) C: N$ ratio $(38.41-1.18 * x, P<0.001$, $\mathbf{R}^{2}=\mathbf{0 . 9 1}$ ), of the topographic positions across the elevation gradient. Symbols used for data are: full black, schist material $1000 \mathrm{~m}$; open granite material $1000 \mathrm{~m}$, full grey, $2000 \mathrm{~m}$; white, $3000 \mathrm{~m}$; $\nabla$ Lower Slope, $\bullet$ Midslope, $\triangle$ Ridge

\subsubsection{Soil respiration}

Soil respiration decreased with increasing elevation $(\mathrm{P}<0.001)$ and from the lower slopes to the ridges $(\mathrm{P}<0.03)$ (Table 4.3). Soil respiration ranged from $10.3(0.8) \mathrm{Mg} \mathrm{C} \mathrm{ha}^{-1} \mathrm{yr}^{-1}$ at the lower slopes at $1000 \mathrm{~m}$ to $3.7(0.5) \mathrm{Mg} \mathrm{C} \mathrm{ha}^{-1} \mathrm{yr}^{-1}$ at the ridges of the $3000 \mathrm{~m}$ site. Different geological substrate at the $1000 \mathrm{~m}$ site did not affect soil respiration (Table 4.4). Multiple regression analysis revealed that 
temperature, gravimetric moisture content and $\mathrm{C}: \mathrm{N}$ ratio of aboveground litterfall together influenced soil respiration significantly $(\mathrm{P} \leq 0.001)$ and explained about $63 \%$ of spatial $\mathrm{CO}_{2}$ flux variability. Soil stocks and concentrations of $\mathrm{P}_{\text {tot }}, \mathrm{P}_{\mathrm{av}} . \mathrm{K}_{\text {tot }}$ and $\mathrm{K}_{\mathrm{av}}$ did not influence soil respiration, whereas we found linear correlations between soil respiration and $C$ :nutrient ratios of the litterfall $\left(P=0.003, R^{2}=0.56\right.$ for $C: N, P=0.002, R^{2}=0.60$ for $C: K$ and $P=0.02, R^{2}=0.40$ for $C: P$, Figure 4.2 a-c) and the $C: N$ ratio of the organic layer $\left(\mathrm{P}=0.02, \mathrm{R}^{2}=0.35\right)$. We found a good correlation of soil respiration rates with organic layer thickness $\left(\mathrm{P}<0.01, \mathrm{R}^{2}=0.63\right.$, Figure $\left.4.4 \mathrm{~b}\right)$.
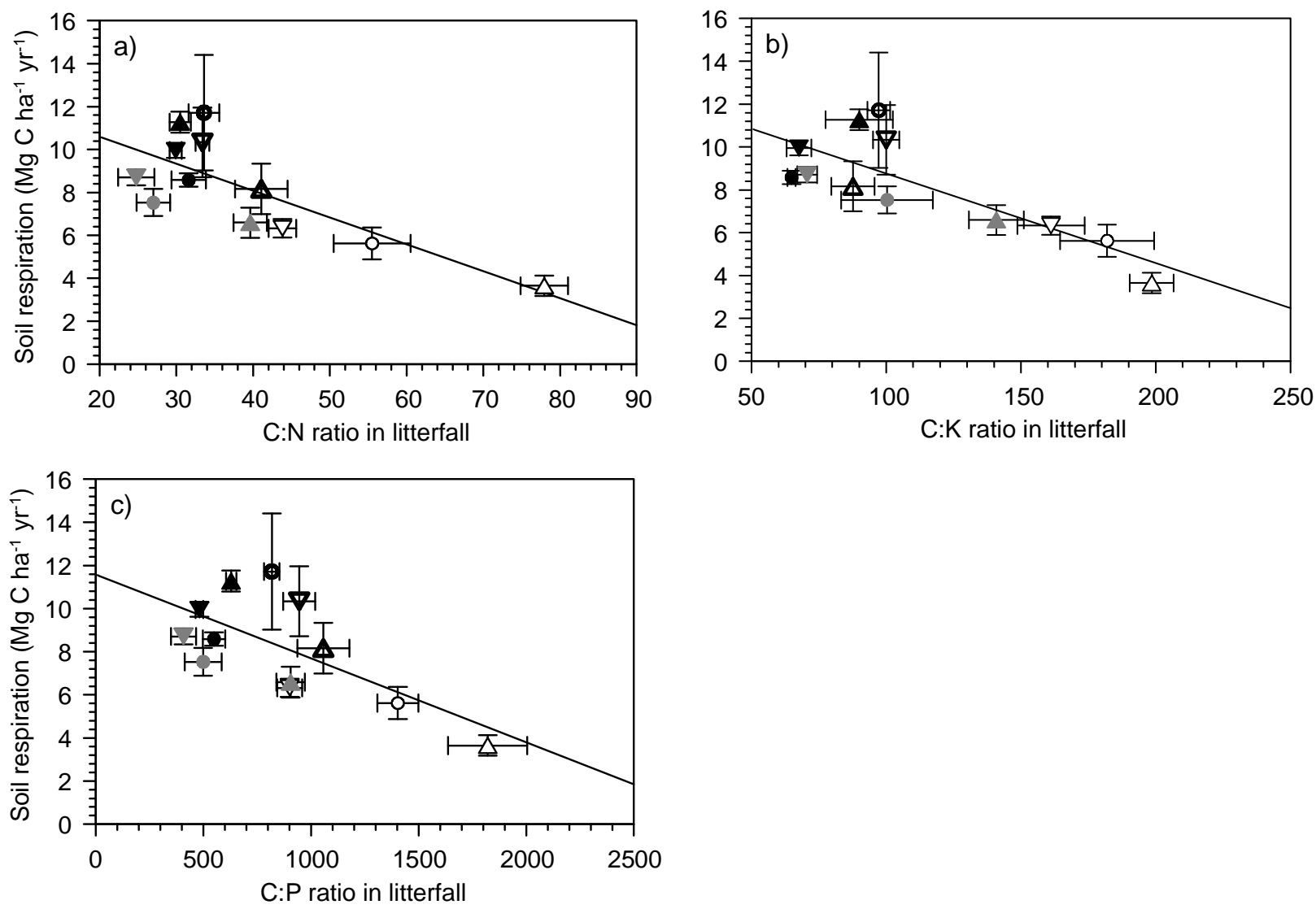

Figure 4.2: Relationship between soil respiration (means \pm standard error) and a) $\mathrm{C}: \mathrm{N}$ ratio in litterfall (y $\left.=13.1-125.4 * x, P=0.003, R^{2}=0.56\right)$, and $\left.b\right) C: K$ ratio in litterfall $(y=13.0-41.9 * x, P=0.002$, $\left.R^{2}=0.60\right)$, c) $C: P$ ratio in litterfall $\left(y=11.6-3.9 * x, P=0.02, R^{2}=0.40\right)$ and d) organic layer thickness $(y$ $\left.=10.4-244.1 * x, P=0.002, R^{2}=0.62\right)$ of the topographic positions across the elevation gradient. Symbols used for data are: full black, schist material $1000 \mathrm{~m}$; open granite material $1000 \mathrm{~m}$, full grey, 2000 m; white, 3000 m; $\nabla$ Lower Slope, • Midslope, $\triangle$ Ridge. 
Table 4.3: Carbon fluxes ( $\left.\mathrm{Mg} \mathrm{C} \mathrm{ha}^{-1} \mathrm{yr}^{-1}\right)$ of the topographic positions across the elevation gradient.

\begin{tabular}{|c|c|c|c|c|c|c|c|c|c|}
\hline & \multicolumn{3}{|c|}{$1000 \mathrm{~m}$} & \multicolumn{3}{|c|}{$2000 \mathrm{~m}$} & \multicolumn{3}{|c|}{$3000 \mathrm{~m}$} \\
\hline & Lower slope & Midslope & Ridge & Lower slope & Midslope & Ridge & Lower slope & Midslope & Ridge \\
\hline Soil respiration & $10.3(0.8) \mathrm{aA}$ & $10.3(1.4) \mathrm{aA}$ & $9.8(0.9) \mathrm{aA}$ & $8.8(0.4) \mathrm{aA}$ & $7.6(0.6) \mathrm{aAB}$ & $6.7(0.7) \mathrm{aB}$ & $6.4(0.4) a B$ & $5.7(0.8) \mathrm{abB}$ & $3.7(0.5) b C$ \\
\hline $\begin{array}{l}\text { Aboveground litter } \\
\text { production }\end{array}$ & $3.7(0.2) \mathrm{abA}$ & $4.4(0.2) \mathrm{aA}$ & $3.4(0.3) \mathrm{bA}$ & $4.8(0.3) \mathrm{aB}$ & $5.0(0.3) \mathrm{aA}$ & $3.8(0.1) \mathrm{bA}$ & $2.5(0.1) \mathrm{aC}$ & $2.6(0.3) \mathrm{aB}$ & $2.5(0.1) \mathrm{aB}$ \\
\hline AGB & $6.9(0.5) \mathrm{A}$ & $7.1(0.5) \mathrm{A}$ & $6.0(0.9) \mathrm{A}$ & $7.9(0.8) \mathrm{aA}$ & $7.0(0.5) \mathrm{abA}$ & $5.1(0.3) \mathrm{bA}$ & $3.4(0.2) \mathrm{B}$ & $3.1(0.4) \mathrm{B}$ & $2.9(0.1) \mathrm{B}$ \\
\hline TBCA & $6.6(0.9) \mathrm{aA}$ & $5.8(1.5) \mathrm{a}$ & $6.4(0.8) \mathrm{aA}$ & $4.1(0.3) \mathrm{aB}$ & $2.6(1.0) \mathrm{a}$ & $2.9(0.7) \mathrm{aB}$ & $3.9(0.4) \mathrm{aB}$ & $3.1(0.7) \mathrm{a}$ & $1.2(0.5) b B$ \\
\hline $\begin{array}{l}\text { TBCA: Aboveground } \\
\text { productivity }\end{array}$ & $1.0(0.2) \mathrm{AB}$ & $0.9(0.2)$ & $1.1(0.1) \mathrm{A}$ & $0.5(0.1) \mathrm{A}$ & $0.4(0.2)$ & $0.6(0.1) \mathrm{B}$ & $1.2(0.1) \mathrm{aB}$ & $1.1(0.3) \mathrm{ab}$ & $0.4(0.2) \mathrm{bB}$ \\
\hline
\end{tabular}

Means $( \pm$ SE, $n=6)$ within rows followed by different letter indicate significant differences among topographic positions at each elevation (small letters) and differences among elevations at each topographic position (capital letters) (two-way ANOVA with Tukey HSD test at $P \leq 0.05)$.

Table 4.4: Carbon fluxes, available and total nutrient stocks at different soil depths of two different geological substrates at the $1000 \mathrm{~m}$ site

\begin{tabular}{|c|c|c|c|c|c|c|}
\hline & \multicolumn{3}{|c|}{$1000 \mathrm{~m}$ Schist } & \multicolumn{3}{|c|}{1000 m Granite } \\
\hline & Lower slope & Midslope & Ridge & Lower slope & Midslope & Ridge \\
\hline Soil respiration $\left(\mathrm{Mg} \mathrm{ha}^{-1} \mathrm{yr}^{-1}\right)$ & $10.1(03) \mathrm{a}$ & $8.7(0.3) b$ & $11.4(0.5) \mathrm{a}$ & $10.4(1.6)$ & $11.8(2.7)$ & $8.3(1.2)$ \\
\hline $\begin{array}{l}\text { Aboveground litterfall C } \\
\left(\mathrm{Mg} \mathrm{ha}^{-1} \mathrm{yr}^{-1}\right)\end{array}$ & $3.9(0.2)$ & $4.7(0.4)$ & $4.0(0.2) \mathrm{A}$ & $3.5(0.3) \mathrm{ab}$ & $4.1(0.2) \mathrm{a}$ & $2.9(0.2) \mathrm{bB}$ \\
\hline TBCA (Mg ha $\left.{ }^{-1} \mathrm{yr}^{-1}\right)$ & $6.2(0.3) \mathrm{a}$ & $4.0(0.5) \mathrm{b}$ & $7.4(0.7) \mathrm{a}$ & $7.0(1.9)$ & $7.7(2.7)$ & $5.4(1.3)$ \\
\hline TBCA: Aboveground litterfall C & $1.6(0.1) \mathrm{ab}$ & $0.9(0.2) \mathrm{a}$ & $1.9(0.3) \mathrm{b}$ & $2.1(0.8)$ & $1.9(0.7)$ & $1.9(0.6)$ \\
\hline \multicolumn{7}{|l|}{ Litterfall } \\
\hline $\mathrm{C}: \mathrm{N}$ & $29.9(0.8) \mathrm{A}$ & $31.6(2.3)$ & $30.5(1.4) \mathrm{A}$ & $33.4(0.9) \mathrm{B}$ & $33.6(2.0)$ & $41.1(3.4) \mathrm{B}$ \\
\hline $\mathrm{C}: \mathrm{K}$ & $67.6(4.6) \mathrm{A}$ & $64.9(1.5) \mathrm{A}$ & $90.0(12.5)$ & 100.0 (4.9)B & 97.2 (4.2)B & $87.7(8.0)$ \\
\hline $\mathrm{C}: \mathrm{P}$ & $481.6(17.6) \mathrm{A}$ & $549.8(52.0) \mathrm{A}$ & $629.5(24.4) \mathrm{A}$ & $945.1(74.4) \mathrm{B}$ & $818.0(35.6) \mathrm{B}$ & $1057.7(121.0) \mathrm{B}$ \\
\hline $\begin{array}{l}\text { Aboveground litterfall } \mathrm{N} \\
\left(\mathrm{kg} \mathrm{ha}^{-1} \mathrm{yr}^{-1}\right)\end{array}$ & $129.1(8.4)$ & $149.3(10.3)$ & $131.2(10.1) \mathrm{A}$ & $103.6(7.0) \mathrm{a}$ & $123.8(5.4) \mathrm{a}$ & $70.0(3.1) \mathrm{bB}$ \\
\hline Aboveground litterfall $\mathrm{K}$ & $3.9(0.2) \mathrm{A}$ & $4.0(0.1) \mathrm{A}$ & $3.3(0.5)$ & $2.8(0.2) \mathrm{B}$ & $2.8(0.1) \mathrm{B}$ & $3.2(0.2)$ \\
\hline
\end{tabular}


$\left(\mathrm{kg} \mathrm{ha}^{-1} \mathrm{yr}^{-1}\right)$

Aboveground litterfall $\mathrm{P}$

$\left(\mathrm{kg} \mathrm{ha}^{-1} \mathrm{yr}^{-1}\right.$ )

\section{Organic Layer}

$\mathrm{P}$ tot $\left(\mathrm{kg} \mathrm{ha}^{-1} \mathrm{yr}^{-1}\right)$

$\mathrm{P}$ av $\left(\mathrm{kg} \mathrm{ha}^{-1} \mathrm{yr}^{-1}\right)$

$\mathrm{K}$ tot $\left(\mathrm{kg} \mathrm{ha}^{-1} \mathrm{yr}^{-1}\right)$

$\mathrm{C}: \mathrm{N}$

\section{Mineral Soil 0-10cm}

$\mathrm{P}$ tot $\left(\mathrm{kg} \mathrm{ha}^{-1} \mathrm{yr}^{-1}\right)$

$\mathrm{P}$ av $\left(\mathrm{kg} \mathrm{ha}^{-1} \mathrm{yr}^{-1}\right)$

$\mathrm{K}$ tot $\left(\mathrm{Mg} \mathrm{ha}^{-1} \mathrm{yr}^{-1}\right)$

$\mathrm{K}_{\text {av }}{ }^{\mathrm{b}}\left(\mathrm{kg} \mathrm{ha}^{-1} \mathrm{yr}^{-1}\right)$

$\mathrm{C}: \mathrm{N}$

\section{Mineral Soil 10-20cm}

$\mathrm{P}$ tot $\left(\mathrm{Mg} \mathrm{ha}^{-1} \mathrm{yr}^{-1}\right)$

$\mathrm{P}$ av $\left(\mathrm{kg} \mathrm{ha}^{-1} \mathrm{yr}^{-1}\right)$

$\mathrm{K}$ tot $\left(\mathrm{Mg} \mathrm{ha}^{-1} \mathrm{yr}^{-1}\right)$

$\mathrm{K} \mathrm{av}^{\mathrm{b}}\left(\mathrm{kg} \mathrm{ha}^{-1} \mathrm{yr}^{-1}\right)$

$\mathrm{C}: \mathrm{N}$

$0.8(0.1) \mathrm{A}$
$76.0(21.4)$
$11.4(4.5)$
$622.1(222.0)$
$17.8(1.3)$
$23.5(29.9) \mathrm{aA}$
$4.2(2.2) \mathrm{a}$
$3.3(0.1) \mathrm{aA}$
$2.0(17.9) \mathrm{ab}$
$16.3(0.6)$

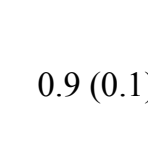

$83.0(10.0)$
$9.0(0.7)$
$511.5(102.1)$
$17.8(\mathrm{NA})$

$311.3(114.9) \mathrm{a}$

$31.9(20.2)$

$5.1(0.7) \mathrm{ab}$

$47.5(12.0)$

$14.7(0.9) \mathrm{a}$

$0.6(0.01) \mathrm{A}$
$86.8(46.4)$
$13.7(5.8)$
$647.4(412.1)$
$19.1(0.1) \mathrm{A}$
$149.9(16.7) \mathrm{a}$
$11.2(0.9) \mathrm{a}$
$2.7(0.2) \mathrm{aA}$
$11.2(0.8) \mathrm{b}$
$19.0(0.9) \mathrm{A}$
$144.8(22.6) \mathrm{a}$
$10.1(2.1)$
$3.4(0.4) \mathrm{bA}$
$10.0(0.3) \mathrm{A}$
$18.6(0.8) \mathrm{bA}$

$0.4(0.04) \mathrm{B}$

$0.5(0.03)$

$0.3(0.02) \mathrm{B}$

$14.9(2.7)$

$1.5(0.4)$

$76.5(5.2)$

$19.2(0.5)$

$46.8(17.3)$

$19.0(3.3)$

$11.8(5.3)$

$4.3(0.4)$

$158.8(53.5)$

$41.5(13.7)$

$19.0(2.5)$

$21.9(0.6) \mathrm{B}$

$84.1(9.6) \mathrm{B} \quad 123.8(9.7) \mathrm{B} \quad 105.2(21.9)$

$7.4(0.4)$

$12.4(0.7) \mathrm{B}$

$9.2(1.4)$

$0.9(0.1) \mathrm{aB} \quad 1.5(0.2) \mathrm{bB} \quad 0.5(0.1) \mathrm{aB}$

$19.3(5.7)$

$25.6(6.8) \mathrm{B}$

$7.3(1.9)$

$16.4(1.2) \mathrm{a}$

$15.6(0.1) \mathrm{a}$

$23.6(0.8) \mathrm{bB}$

$63.5(7.6) \quad 109.0(6.4) \mathrm{B} \quad 88.5(21.3)$

$6.1(1.0)$

$10.9(1.6) \mathrm{B}$

$7.0(1.5)$

$1.2(0.3) \mathrm{ab}$

$1.6(0.2) \mathrm{aB}$

$0.6(0.1) \mathrm{bB}$

$11.2(3.4)$

13.8 (NA)

$1.6(0.2) \mathrm{B}$

$13.5(0.8) \mathrm{a}$

NA No data not available, NA for standard errors if the mean is one repetition

${ }^{\mathrm{a}} \mathrm{K}_{\mathrm{av}}$ determination using the $\mathrm{NaHCO} 3$ extracts of the Hedley fractionation

${ }^{\mathrm{b}} \mathrm{K}_{\mathrm{av}}$ determination via measurement of cation exchange capacity from soil profiles 


\subsubsection{Aboveground productivity}

Different substrate at the $1000 \mathrm{~m}$ site influenced aboveground litter production $(\mathrm{P}=0.03)$, with lower productivity over granite. Litter $\mathrm{C}$ concentrations and total litter production were correlated negatively $\left(\mathrm{P}=0.03, \mathrm{R}^{2}=0.35\right)$ along the environmental gradients. Both elevation and topography affected aboveground litter production $(\mathrm{P} \leq 0.001)$ with highest productivity at the lower slope and midslope position of the $2000 \mathrm{~m}$ site and lowest values at all positions of the $3000 \mathrm{~m}$ site (Table 4.3). Aboveground litter production followed a saturation function with $\mathrm{K}_{\text {tot }}$ of the organic layer $\left(\mathrm{P}=0.01, \mathrm{R}^{2}=0.65\right.$, Figure $\left.4.3 \mathrm{c}\right)$, and $\mathrm{P}_{\text {tot }}$ in the mineral soil $(\mathrm{P}<0.001$, $\mathrm{R}^{2}=0.85$ at $0-10 \mathrm{~cm}$, Figure $4.3 \mathrm{f}$, and $\mathrm{P}=0.001, \mathrm{R}^{2}=0.67$ at $10-20 \mathrm{~cm}$, data not shown). Linear correlations were found with $\mathrm{P}_{\text {tot }}$ and $\mathrm{P}_{\mathrm{av}}$ stocks in the organic layer $\left(\mathrm{P}<0.01, \mathrm{R}^{2}=0.61\right.$ for $\mathrm{P}_{\text {tot }}$ and $\mathrm{P}=0.01, \mathrm{R}^{2}=0.41$ for $\mathrm{P}_{\mathrm{av}}$ Figure $\left.4.3 \mathrm{~b}, \mathrm{~d}\right)$ and with $\mathrm{K}_{\text {tot }}$ at $0-10 \mathrm{~cm}$ depth $(\mathrm{P}<0.03$, $\mathrm{R}^{2}=0.31$; Figure $4.3 \mathrm{e}$ ). Weaker linear correlations were found with $\mathrm{P}_{\mathrm{av}}$ of the mineral soil depths $\left(\mathrm{P}=0.06, \mathrm{R}^{2}=0.24\right.$ at $0-10 \mathrm{~cm}, \mathrm{P}=0.04, \mathrm{R}^{2}=0.31$ at $10-20 \mathrm{~cm}$ soil depth, data not shown). Aboveground litter production also correlated with $\mathrm{C}$ :nutrient ratios of litterfall $\left(\mathrm{P}=0.005, \mathrm{R}^{2}=0.52\right.$ for $\mathrm{C}: \mathrm{K}$ and $\mathrm{P}=0.001, \mathrm{R}^{2}=0.64$ for $\mathrm{C}: \mathrm{P}$ and $\mathrm{P}<0.001, \mathrm{R}^{2}=0.75$ for $\left.\mathrm{C}: \mathrm{N}\right)$ and the $C: N$ ratio of the organic layer $\left(P<0.001, R^{2}=0.74\right.$, Figure 4.3 a). Correlations with $C: N$ ratios of the mineral soil were less pronounced $\left(\mathrm{P}<0.03, \mathrm{R}^{2}=0.33\right.$ for $0-10 \mathrm{~cm}$ depth and $\mathrm{P}<0.02, \mathrm{R}^{2}=0.38$ for the $10-20 \mathrm{~cm}$ depth). Soil respiration and aboveground litter production did not correlate along the environmental gradients.

Aboveground productivity, estimated as the sum of aboveground litter production and wood increment, followed the trends shown for aboveground litter productivity, with highest values at the at the lower slope and midslope position of the $2000 \mathrm{~m}$ site and lowest values at all positions of the $3000 \mathrm{~m}$ site (Table 4.3). We found significant influence of both elevation and topography on aboveground productivity $(\mathrm{P} \leq 0.005)$. 

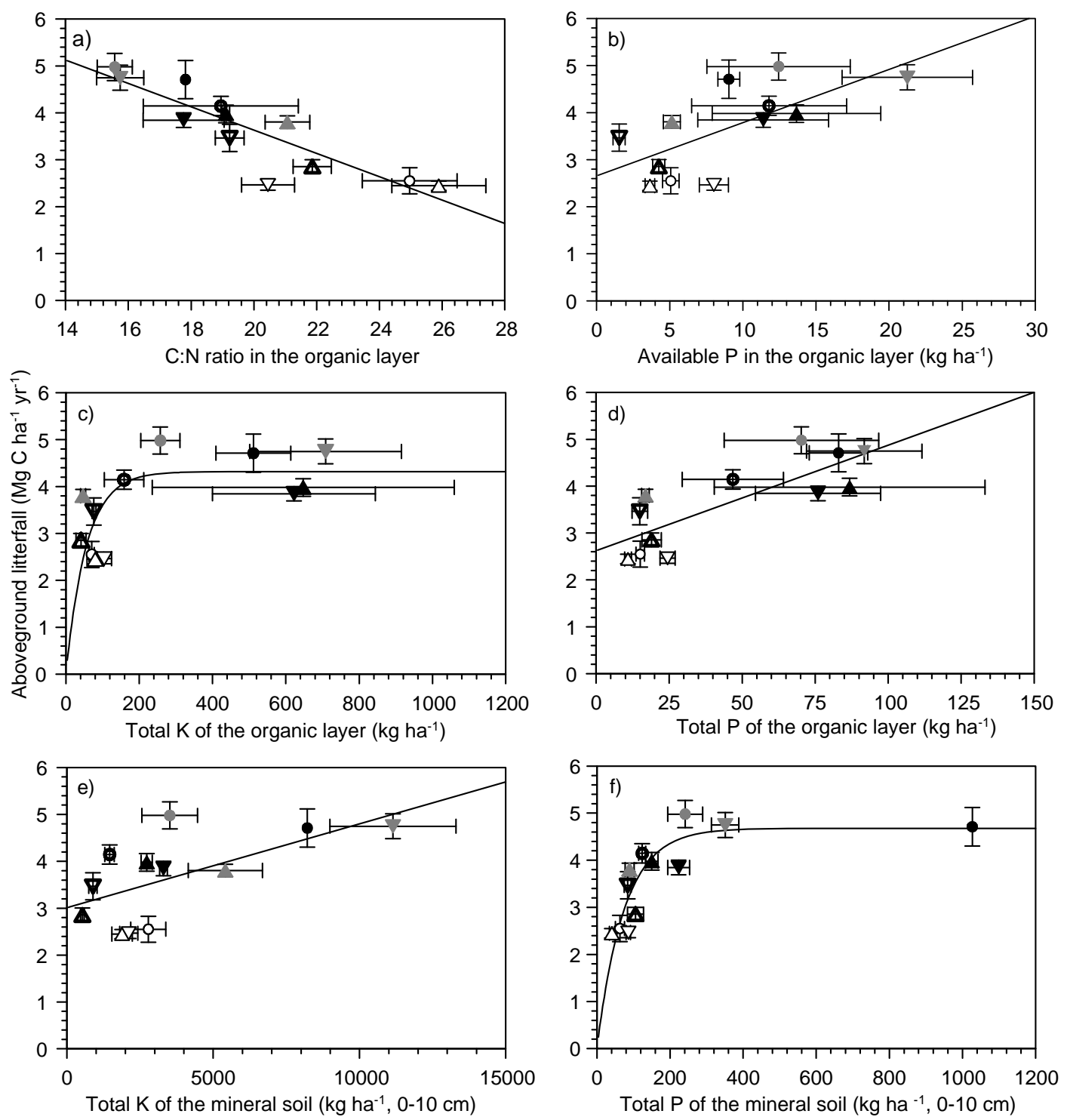

Figure 4.3: Relationship between aboveground litterfall and nutrient stocks (means \pm standard error) and a) $C: N$ ratio in the organic layer $\left(8.61-248.70 * x, P<0.01, R^{2}=0.74\right)$, b) available phosphorus in the organic layer $\left(Y=2.7+113.1 * x, P=0.01, R^{2}=0.41\right)$, c) total potassium in the organic layer $\left(y=a *(1-\exp (-b * x)), a=4.3 \pm 0.4, b=0.02 \pm 6.2 * 10^{-6}, P<0.001, R^{2}=0.65\right)$, and d) total phosphorus in the organic layer $\left(\mathrm{Y}=2.6+22.5 * \mathrm{x}, \mathrm{P}<0.01, \mathrm{R}^{2}=0.61\right)$, e) total potassium in the mineral soil $(0-10 \mathrm{~cm}$ depth $)\left(y=3.0+0.2 * x, P=0.03, R^{2}=0.32\right)$ and, $\left.f\right)$ total phosphorus in the mineral soil $\left(0-10 \mathrm{~cm}\right.$ depth) $\left(y=a *(1-\exp (-b * x)), a=4.7 \pm 0.6, b=0.01 \pm 4.7 * 10^{-6}, P<0.001\right.$, $\mathbf{R}^{2}=\mathbf{0 . 8 5}$ ) of the topographic positions across the elevation gradient. Symbols used for data are: full black, schist material $1000 \mathrm{~m}$; open granite material $1000 \mathrm{~m}$, full grey, $2000 \mathrm{~m}$; white, $3000 \mathrm{~m}$; Lower Slope, $\bullet$ Midslope, $\triangle$ Ridge. 


\subsubsection{Total belowground carbon allocation}

TBCA, as estimated by the difference between soil respiration and litterfall $\mathrm{C}$, decreased from 6.6 $\mathrm{Mg} \mathrm{C} \mathrm{ha}^{-1} \mathrm{yr}^{-1}$ at the $1000 \mathrm{~m}$ site to $1.2 \mathrm{Mg} \mathrm{C} \mathrm{ha}^{-1} \mathrm{yr}^{-1}$ at the $3000 \mathrm{~m}$ site and was highest at the lower slope positions of all elevations (Table 4.3). Absolute TBCA did not correlate with any of the nutrient contents at neither soil depths, but was negatively correlated with gravimetric soil moisture content $\left(\mathrm{P}=0.002, \mathrm{R}^{2}=0.60\right.$, Figure $\left.4.4 \mathrm{c}\right)$ and organic layer thickness $(\mathrm{P}=0.003$, $\mathrm{R}^{2}=0.58$, Figure $4.4 \mathrm{~d}$ ). We found a weak linear correlation of absolute TBCA with $\mathrm{C}: \mathrm{K}$ ratio of litterfall $\left(\mathrm{P}=0.04, \mathrm{R}^{2}=0.29\right)$, whereas $\mathrm{C}: \mathrm{N}$ and $\mathrm{C}: \mathrm{P}$ ratios of the litterfall did not influence TBCA. TBCA showed no correlation with aboveground litter production. The ratio between TBCA and aboveground productivity, as determined from the sum of litter production and wood increment (relative TBCA), ranged between 0.4 and 1.2. Elevation influenced relative TBCA $(\mathrm{P}<0.005)$, while we did only find a topographic effect at the $3000 \mathrm{~m}$ site $(\mathrm{P}=0.02)$. Relative TBCA was lowest at all positions of the $2000 \mathrm{~m}$ site, and at the ridge position of the $3000 \mathrm{~m}$ site (Table 4.3). We did not find any correlation of relative TBCA with total or available nutrients in the soil. Multiple regression analysis showed that $\mathrm{C}: \mathrm{N}$ ratio in litter, $\mathrm{P}$ concentration in litter and gravimetric soil moisture together accounted for $38 \%$ of the variability in relative TBCA data (including ${ }^{15} \mathrm{~N}$ signature of litterfall $45 \%$ ). 

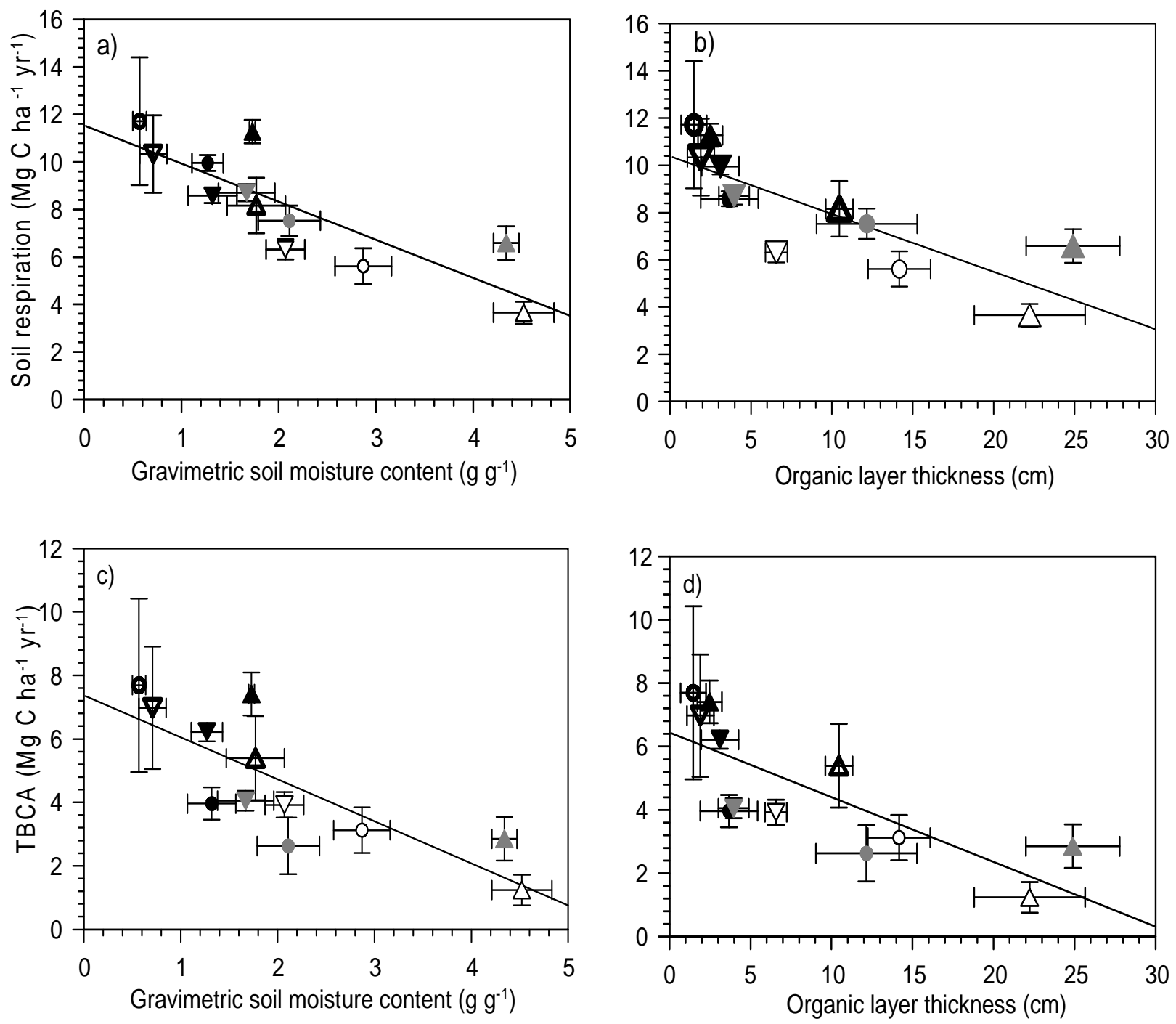

Figure 4.4: Relationship (means \pm standard error) between a) soil respiration and gravimetric soil moisture content $\left(y=9.7-1.4 * x, P<0.005, R^{2}=0.65\right)$ b) soil respiration and organic layer thickness $\left.\left(y=10.4-244.0 * x, P<0.002, R^{2}=0.63\right), c\right)$ TBCA and gravimetric soil moisture content $\left(y=7.4-1.3 * x, P<0.01, R^{2}=0.60\right)$, and $\left.d\right)$ organic layer thickness $(y=6.4-0.2 * x, P<0.01$, $\mathbf{R}^{2}=\mathbf{0 . 5 8}$ ) of the topographic positions across the elevation gradient. Symbols used for data are: full black, schist material $1000 \mathrm{~m}$; open granite material $1000 \mathrm{~m}$, full grey, $2000 \mathrm{~m}$; white, $3000 \mathrm{~m}$; Lower slope, $\bullet$ Midslope, $\triangle$ Ridge. 


\subsection{Discussion}

\subsubsection{Soil respiration}

Soil respiration measured along our elevation gradient was lower than reported for tropical lowland forests (Raich \& Schlesinger, 1992; Köhler et al., 2009a) but fitted into the range of $\mathrm{CO}_{2}$ fluxes given for tropical montane forests $\left(0.65-1.4 \mathrm{~kg} \mathrm{C} \mathrm{ha}^{-1} \mathrm{yr}^{-1}\right)$ of Panama, Colombia, Hawaii and China (Cavelier \& Penuela, 1990; Raich, 1998; McGroddy \& Silver, 2000; Werner et al., 2006; Köhler et al., 2009a). Large parts of the measured soil respiration derived from the decomposition of surface litter, as the correlations of indices of litter quality were significant in contrast to nutrient availability in the organic layer. We could not confirm the positive correlation between soil respiration and aboveground litterfall found by Raich \& Schlesinger (1992) for a wide range of ecosystems. This lack of correlation suggests that the main controlling factors of soil respiration and aboveground litter production are not the same in this ecosystem. Furthermore, this corroborates with findings from Hawaiian forests (Schuur et al., 2001) that increased carbon storage (thick organic layers) was not due to high productivity but due to a decrease in decomposition rates. The positive correlation between organic layer thickness and soil respiration with soil moisture and temperature imply that C-turnover and the and mineralization rates of the organic layer were rather limited by temperature and soil moisture than limited by substrate input as suggested by Raich \& Schlesinger (1992). Aboveground litterfall on the other hand was clearly nutrient limited in wide parts of the study region. Linear correlation of aboveground litter production with nitrogen and phosphorus availability mainly in the organic layer are an indication for $\mathrm{N}$ and $\mathrm{P}$ limitation of tree productivity in the whole investigated area, whereas the saturation functions described by aboveground litter production and available $\mathrm{K}$ indicate limitations only for parts of the study area.

\subsubsection{Soil nutrient availability and aboveground productivity}

Thick organic layers, as they were found in our study area, are common in tropical montane forests (Grubb, 1977; Purbopuspito et al., 2006; Arnold et al., 2009) and imply low mineralization rates and thus low nutrient availability (Edwards \& Grubb, 1977). Such unfavorable soil conditions and impaired nutrient supply combined with low temperatures are 
suggested to hamper tree productivity in montane rain forests (Leuschner et al., 2007). Indeed, the positive correlations of aboveground litter productivity and litter $\mathrm{P}$ and $\mathrm{K}$ concentrations with soil nutrient availability in our study area suggest that tree productivity of these tropical montane rain forests is nutrient limited (Tanner et al., 1998). Although it has to be noted, that K-limitation was probably not given within the entire investigated area. Despite such nutrient limitation and the higher available nutrient contents in the mineral soil, plants seem to obtain nutrients mainly from the organic layer. This assumption is supported by several findings. First, we found closer positive correlations of aboveground litter production with the available nutrients of the organic layer relative to the mineral soil depths. Further evidence for this crucial role of the organic layers as nutrient supplier comes from the studies reporting the occurrence of highest fine root densities within the organic layer of tropical montane forests in Costa Rica and Panama (Cavelier, 1992; Vance \& Nadkarni, 1992; Hertel et al., 2003). Within our study area, at least $80 \%$ of the fine root biomass of a soil profile was located within the organic layer and the uppermost $20 \mathrm{~cm}$ of the mineral soil (Röderstein et al., 2005). Of these 80\% about two thirds were found within the organic layer (estimate from graphics in Röderstein et al.(2005)). A possible explanation for this paradox nutrient acquisition may be the increasing occurrence of water logging in the mineral soil with elevation (Schrumpf et al., 2001) and toward the ridge positions. Hertel et al. (2003) suggest that the high root densities in the organic layer may advance a self-enforcing feedback process as they themselves provided large amounts of decomposing organic material with root death in a old growth montane forest in Costa Rica. A similar process, strengthened by a limited mixing of the organic layer with the mineral soil due to low biological activity (Wilcke et al., 2002), may, for our study area, result in a nutrient cycling system between plants and soil, that is largely uncoupled from the mineral soil.

\subsubsection{Total belowground carbon allocation}

TBCA of our sites were lower than for most lowland sites (Davidson et al., 2002; Litton et al., 2007) and comparable to the values reported by Raich (1998) for comparable elevations in a tropical montane forest in Hawaii. The lack of correlations between aboveground litter production and TBCA in our tropical montane site could not confirm the link between belowground and aboveground primary productivity found by Raich \& Nadelhoffer (1989) and Litton et al. (2007). The authors suggested that an increase of primary productivity would lead to 
a parallel increase in TBCA and aboveground litter production, leaving the ratio TBCA: aboveground litter production constant for a wide range of ecosystems (Davidson et al., 2002). Neither could we confirm our hypothesis that relatively more carbon is allocated belowground than aboveground when nutrient supply declines.

The decrease in TBCA along the elevation gradient seems contradictory to the increasing fine root biomass and increasing root/shoot ratios with elevation, which have been reported for tropical montane forests (Hertel et al., 2003; Hertel \& Leuschner, 2010) including our study area (Röderstein et al., 2005; Leuschner et al., 2007). Although we cannot completely dismiss the possibility of methodological problems, our measurements of aboveground productivity and soil respiration, as well as our estimates for TBCA were within the range of values reported from other tropical montane forests (Raich, 1998). Large root biomass has often been assumed to be synonymic with increases in root productivity and reduction in fine root longevity (Malhi et al., 2004; Leuschner et al., 2007). However, this assumption seems not to hold true for our study area, as the increase in fine root biomass with increasing elevation and toward the ridges went along with a decline in TBCA. One explanation might be that root productivity makes up only about 30\% of TBCA (Nadelhoffer \& Raich, 1992), with much less known about the other carbon fluxes, such as $\mathrm{C}$ allocated to mycorrhizae, root exudates and coarse root production (Gower et al., 1996). Another explanation could be increasing root longevity with increasingly adverse environmental conditions. Together with low decomposition rates in the organic layers, this may lead to higher and longer-term storage of organic $\mathrm{C}$ in the soil. A third possible explanation for the discrepancy between high root density and low TBCA is that TBCA might be underestimated by the carbon balance approach, especially at the highest elevation and the very poor ridge positions of the $2000 \mathrm{~m}$ site due to very low soil respiration rates.

In summary, we found a clear dependence of aboveground productivity and soil respiration on nutrient availability, and that nutrient cycling is mainly constricted to the organic layers and litter layer. The results obtained from our estimations of TBAC were controversial. Consequently, more direct measurements of root productivity rates especially in altitudes above $2000 \mathrm{~m}$ are needed to ascertain if the carbon balance approach by Raich \& Nadelhoffer (1989) to estimate TBCA on a global scale, is applicable to tropical montane rain forests on a regional scale. 


\subsection{References}

Aragao, L., Malhi, Y., Metcalfe, D.B., Silva-Espejo, J.E., Jimenez, E., Navarrete, D., Almeida, S., Costa, A.C.L., Salinas, N., Phillips, O.L., Anderson, L.O., Alvarez, E., Baker, T.R., Goncalvez, P.H., Huaman-Ovalle, J., Mamani-Solorzano, M., Meir, P., Monteagudo, A., Patino, S., Penuela, M.C., Prieto, A., Quesada, C.A., Rozas-Davila, A., Rudas, A., Silva, J.A., Vasquez, R. (2009) Above- and below-ground net primary productivity across ten Amazonian forests on contrasting soils. Biogeosciences 6, 2759-2778.

Arnold, J., Corre, M.D., Veldkamp, E. (2009) Soil N cycling in old-growth forests across an Andosol toposequence in Ecuador. Forest Ecology and Management 257, 2079-2087.

Blake, G.R., Hartge, K.H. (1986) Bulk density. In: Klute, A. (Ed.), Methods of soil analysis, part 1. Physical and mineralogical methods. Agronomy Monograph, Soil Science Society of America, Madison, Wisconsin, USA, p. 12.

Bliese, P.D., Ployhart, R.E. (2002) Growth Modeling Using Random Coefficient Models: Model Building, Testing, and Illustrations. Organizational Research Methods 5, 362-387.

Bruijnzeel, L.A., Veneklaas, E.J. (1998). Climatic conditions and tropical, montane forest productivity: The fog has not lifted yet. Ecology 79, 3-9.

Cavelier, J., (1992) Fine-root biomass and soil properties in a semideciduous and a lower montane rain-forest in Panama. Plant and Soil 142, 187-201.

Cavelier, J., Penuela, M.C. (1990). Soil respiration in the cloud forest and dry decisuous forest of Sierra de Macuira, Colombia Biotropica 22, 346-352.

Chave,J., Andalo, C., Brown, S., Cairns, M., Chambers, J., Eamus, D., Fölster, H., Fromard, F., Higuchi, N., Kira, T. (2005)Tree allometry and improved estimation of carbon stocks and balance in tropical forests. Oecologia 145 (1), 87-99.

Chave, J., Olivier, J., Bongers, F., Châtelet, P., Forget, P.-M., van der Meer, P., Norden, N., Riéra, B., Charles-Dominique, P. (2008) Above-ground biomass and productivity in a rain forest of eastern south america. Journal of Tropical Ecology 24 (04), 355-366.

Crawley, M.J., (2009) The R book. John Wiley \& Sons Ltd, Chinchester, West Sussex.

Cross, A.F., Schlesinger, W.H. (1995) A literature review and evaluation of the. Hedley fractionation: Applications to the biogeochemical cycle of soil phosphorus in natural ecosystems. Geoderma 64, 197-214.

Davidson, E.A., Savagea, K., Bolstad, P., Clark, D.A., Curtis, P.S., Ellsworth, D.S., Hanson, P.J., Lawg, B.E., Luoh, Y., Pregitzer, K.S., Randolph, J.C., Zakk, D. (2002) Belowground carbon allocation in forests estimated from litterfall and IRGA-based soil respiration measurements. Agricultural and Forest Meteorology 113, 39-51.

Edwards, P.J., Grubb, P.J. (1977). Studies of mineral cycling in a montane rain-forest in NewGuinea: 1. Distribution of organic-matter in vegetation and soil. Journal of Ecology 65, 943-969.

Giardina, C.P., Ryan, M.G. (2002) Total Belowground Carbon Allocation in a Fast-growing Eucalyptus Plantation Estimated Using a Carbon Balance Approach. Ecosystems 5, 487499.

Giardina, C.P., Ryan, M.G., Binkley, D., Fownes, J.H. (2003) Primary production and carbon allocation in relation to nutrient supply in a tropical experimental forest. Global Change Biology 9, 1438-1450. 
Girardin, C.A.J., Malhi, Y., Aragão, L.E.O.C., Mamani, M., Huaraca Huasco, W., Durand, L., Feeley, K.J., Rapp, J., Silva-Espejo, J.E., Silman, M., Salinas, N., Whittaker, R.J., (2010) Net primary productivity allocation and cycling of carbon along a tropical forest elevational transect in the Peruvian Andes. Global Change Biology16, 12, 3176-3192.

Gower, S.T., Pongracic, S., Landsberg, J.J. (1996) A global trend in belowground carbon allocation: Can we use the relationship at smaller scales? Ecology 77, 1750-1755.

Grubb, P.J. (1977) Control of forest growth and distribution on wet tropical mountains: with special reference to mineral nutrition. Annual Review of Ecology and Systematics 8, 83107.

Heinrichs, H., Brumsack, H.J., Loftfield, N., Konig, N. (1986) Improved pressure digestion system for biological and anorganic materials. Zeitschrift für Pflanzenernahrung und Bodenkunde 149, 350-353.

Hertel, D., Leuschner, C. (2010). Fine root mass and fine root production in tropical moist forests as dependent on soil, climate and elevation. In: Bruijnzeel, L., Juvik, J. (Eds.), Mountains in the mist: Science for conserving and managing tropical montane cloud forests. Hawaii University Press, 428-444.

Hertel, D., Leuschner, C., Hölscher, D. (2003). Size and Structure of Fine Root Systems in Oldgrowth and Secondary Tropical Montane Forests (Costa Rica). Biotropica 35, 143-153.

Homeier, J., Breckle, S.-W., Günter, S., Rollenbeck, R.T., Leuschner, C. (2010). Tree diversity, forest structure and productivity along altitudinal and topographical gradients in a speciesrich Ecuadorian montane rain forest. Biotropica 42, 140-148.

Homeier, J., Werner, F.A., Gradstein, S.R., Breckle, S.-W., Richter, M. (2008). Potential vegetation and floristic composition of Andean forests in south Ecuador, with a focus on the RBSF. In: Erwin Beck, J.B., Ingrid Kottke, Franz Makeschin, Reinhard Mosandl (Ed.), Ecological studies: Gradients in tropical mountain ecosystem of Ecuador. SpringerVerlag, Berlin, Heidelberg.

Keith, H., Jacobsen, K.L., Raison, R.J. (1997a). Effects of soil phosphorus availability, temperature and moisture on soil respiration in Eucalyptus pauciflora forest. Plant and Soil 190, 127-141.

Keith, H., Raison, R.J., Jacobsen, K.L. (1997b). Allocation of carbon in a mature eucalypt forest and some effects of soil phosphorus availability. Plant and Soil 196, 81-99.

Köhler, B., Corre, M.D., Veldkamp, E., Sueta, J.P. (2009a). Chronic nitrogen addition causes a reduction in soil carbon dioxide efflux during the high stem-growth period in a tropical montane forest but no response from a tropical lowland forest in decadal scale. Biogeosciences Discussions 6, 1-28.

Köhler, B., Corre, M.D., Veldkamp, E., Wullaert, H., Wright, J.S. (2009b). Immediate and longterm nitrogen oxide emissions from tropical forest soils exposed to elevated nitrogen imput. Global Change Biology.

König, N., Fortmann, H. (1996). Probenvorbereitungs-, Untersuchungs- und Elementbestimmungs-Methoden des Umweltanalytik-Labors der Niedersächsischen Forstlichen Versuchsanstalt, Reihe B. University of Göttingen, Göttingen, Germany.

Leuschner, C., Moser, G., Bertsch, C., Röderstein, M., Hertel, D. (2007). Large altitudinal increase in tree root/shoot ratio in tropical mountain forests of Ecuador. Basic and Applied Ecology 8, 219-230.

Link, R. (2010). The variation of wood specifc gravity and aboveground biomass along gradients of topography and elevation in tropical montane forests of southern Ecuador. Albrecht- 
von-Haller-Institut für Pflanzenwissenschaften Abteilung Ökologie und Ökosystemforschung, . Georg August Universität Göttingen, Göttingen.

Litherland, M., Aspen, J.A., Lemielita, R.A. (1994). The metamorphic belts of Ecuador. Overseas Memoir of the British Geological Survey 11.

Litton, C.M., Raich, J.W., Ryan, M.G. (2007). Carbon allocation in forest ecosystems. Global Change Biology 13, 2089-2109.

Livingston GP, Hutchinson GL \& Spartalian K (2006) Trace gas emission in chambers: A nonsteady-state diffusion model. Soil Science Society of America Journal 70: 1459-1469.

Loftfield, N., Flessa, H., Augustin, J., Beese, F. (1997). Automated gas chromatographic system for rapid analysis of the atmospheric trace gases methane, carbon dioxide, and nitrous oxide. Journal of Environmental Quality 26, 560-564.

Malhi, Y., Baker, T.R., Phillips, O.L., Almeida, S., Alvarez, E., Arroyo, L., Chave, J., Czimczik, C.I., Di Fiore, A., Higuchi, N., Killeen, T.J., Laurance, S.G., Laurance, W.F., Lewis, S.L., Montoya, L.M.M., Monteagudo, A., Neill, D.A., Vargas, P.N., Patino, S., Pitman, N.C.A., Quesada, C.A., Salomao, R., Silva, J.N.M., Lezama, A.T., Martinez, R.V., Terborgh, J., Vinceti, B., Lloyd, J. (2004). The above-ground coarse wood productivity of 104 Neotropical forest plots. Global Change Biology 10, 563-591.

McConnaughay, K.D.M., Coleman, J.S. (1999). Biomass allocation in plants: Ontogeny or optimality? A test along three resource gradients. Ecology 80, 2581-2593.

McGroddy, M., Silver, W.L. (2000). Variations in Belowground Carbon Storage and Soil CO2 Flux Rates along a Wet Tropical Climate Gradient1. Biotropica 32, 614-624.

Moser, G., Hertel, D., Leuschner, C. (2007). Altitudinal change in LAI and stand leaf biomass in tropical montane forests: a transect study in Ecuador and a pan-tropical meta-analysis. Ecosystems 10, 924-935.

Nadelhoffer, K.J., Raich, J.W. (1992). Find root production estimates and belowground carbon allocation in forest ecosystems. Ecology 73, 1139-1147.

Purbopuspito, J., Veldkamp, E., Brumme, R., Murdiyarso, D. (2006). Trace gas fluxes and nitrogen cycling along an elevation sequence of tropical montane forests in Central Sulawesi, Indonesia. Global Biogeochemical Cycles 20, 11.

Raich, J.W. (1998). Aboveground productivity and soil respiration in three Hawaiian rain forests. Forest Ecology and Management 107, 309-318.

Raich, J.W., Nadelhoffer, K.J. (1989). Belowground carbon allocation in forest Ecosystems: Global trends. Ecology 70, 1346-1354.

Raich, J.W., Schlesinger, W.H. (1992). The global carbon-dioxide flux in soil respiration and its relationship to vegetation and climate. Tellus Series B-Chemical and Physical Meteorology 44, 81-99.

Röderstein, M., Hertel, D., Leuschner, C. (2005). Above- and below-ground litter production in three tropical montane forests in southern Ecuador. Journal of Tropical Ecology 21, 483492.

Schlesinger, W.H., Lichter, J. (2001). Limited carbon storage in soil and litter of experimental forest plots under increased atmospheric CO2. Nature 411, 466-469.

Schlichting E., B.H.P., Stahr K. (1995). Bodenkundliches Praktikum. Blackwell Wissenschafts Verlag, Berlin, Wien.

Schrumpf, M., Guggenberger, G., Valarezo, C., Zech, W. (2001). Tropical montane rain forest soils- Developement and nutrient status along an altitudinal gradient in the South Ecuadorian Andes. Die Erde 132, 43-59. 
Schuur, E.A.G., Chadwick, O.A., Matson, P.A. (2001). Carbon cycling and soil carbon storage in mesic to wet Hawaiian montane forests. Ecology 82, 3182-3196.

Tanner, E.V.J., Vitousek, P.M., Cuevas, E. (1998). Experimental investigation of nutrient limitation of forest growth on wet tropical mountains. Ecology 79, 10-22.

Tiessen, H., Moir, J.O. (1993). Characterisation of available P by sequential extraction. CRC Press, Boca Raton.

Vance, E., Nadkarni, N. (1992). Root biomass distribution in a moist tropical montane forest. Plant and Soil 142, 31-39.

Wagner SW, Reicosky DC \& Alessi RS (1997) Regression models for calculating gas fluxes measured with a closed chamber. Agronomy Journal 89: 279-284.

Walker, T.W., Syers, J.K. (1976). Fate of phosphorous during pedogenesis. Geoderma 15, 1-19.

Werner, C., Zheng, X.H., Tang, J.W., Xie, B.H., Liu, C.Y., Kiese, R., Butterbach-Bahl, K. (2006). N2O, $\mathrm{CH} 4$ and $\mathrm{CO} 2$ emissions from seasonal tropical rainforests and a rubber plantation in Southwest China. Plant and Soil 289, 335-353.

Wilcke, W., Yasin, S., Abramowski, U., Valarezo, C., Zech, W. (2002). Nutrient storage and turnover in organic layers under tropical montane rain forest in Ecuador. European Journal of Soil Science 53, 15-27.

Wullfen, H.-U.v. (1989). Durch einen zwanzigjährigen Phosphat-Düngungsversuch mit variierter P-Düngung verursachte Änderungen im saisonalen pflanzenökologischen P-Status einer Acker-Parabraunerde aus Löß in Süd-Niedersachsen. Fachbereich Agrarwissenschaften Georg-August-Universitaet, Goettingen, p. 139. 



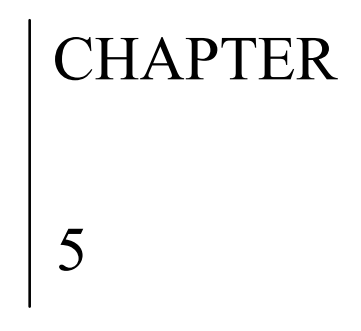

SYNTHESIS 



\subsection{Synthesis and discussion of the major results}

Soil trace gas fluxes were within the range reported from other tropical montane forests and showed rather spatial than temporal pattern

The results from Chapter 2 to 4 show that none of the investigated gases displayed a clear seasonal pattern, which might be related to the absence of a pronounced dry season and the resulting relatively stable soil moisture content. A lack of seasonality in soil trace gas fluxes has also been reported from montane forests in Indonesia (Purbopuspito et al. 2006; Veldkamp et al. 2008). The overview of soil trace gas fluxes in tropical montane forests in Table 5.1 shows that apart from the remarkably large $\mathrm{N}_{2} \mathrm{O}$ fluxes of the lower slope at $2000 \mathrm{~m}(14.5 \pm 2.1) \mathrm{N}$-oxide fluxes from the Ecuadorian soils were within the range reported from other tropical montane forests at comparable elevations. The annual $\mathrm{CH}_{4}$ mean fluxes at the 2000 and $3000 \mathrm{~m}$ sites were within the ranges reported from Indonesia, whereas uptake rates at the $1000 \mathrm{~m}$ site were 24 $55 \%$ higher than the means of other studies. Soil respiration data $\left(\mathrm{CO}_{2}\right.$ emissions $)$ correspond to rates from Colombia, Hawaii, Puerto Rico and Panama. Soil $\mathrm{CO}_{2}$ emission and $\mathrm{CH}_{4}$ uptake rates declined with increasing elevation, whereas $\mathrm{N}_{2} \mathrm{O}$ emissions were highest at the intermediate site, probably due to the high soil $\mathrm{N}$ availability. The effect of topography on trace gas fluxes was less pronounced and more complex. While $\mathrm{CO}_{2}$ emissions followed the expected, however not statistically significant trend of decreasing emissions from the lower slopes toward the ridges, such a decline of $\mathrm{N}$-oxide emissions was only observed at $2000 \mathrm{~m}$ for $\mathrm{N}_{2} \mathrm{O}$, and at $3000 \mathrm{~m}$ for NO. $\mathrm{CH}_{4}$ uptake was not significantly influenced by topography at neither elevation. 
$110 \mid$ CHAPTER 5

Table 5. 1: Compilation of published soil trace gas emissions from old growth tropical montane forest soils*

\begin{tabular}{|c|c|c|c|c|c|c|c|c|c|c|}
\hline \multirow[b]{2}{*}{ Country, site } & \multirow[b]{2}{*}{ Slope position } & \multirow[b]{2}{*}{ Soil type } & \multirow[b]{2}{*}{$\begin{array}{c}\text { Elevation } \\
\text { a.s.l } \\
\text { m }\end{array}$} & \multicolumn{2}{|c|}{ Climate } & \multicolumn{4}{|c|}{ Soil trace gas fluxes } & \multirow[b]{2}{*}{ Reference } \\
\hline & & & & $\begin{array}{c}\text { Mean ann. } \\
\text { Precip. } \\
\text { mm }\end{array}$ & $\begin{array}{c}\text { Mean ann. } \\
\text { Temp } \\
{ }^{\circ} \mathrm{C}\end{array}$ & $\mathrm{N}_{2} \mathrm{O}$ & $\begin{array}{c}\mathrm{NO} \\
\mu \mathrm{g} \mathrm{m}^{-2}\end{array}$ & $\begin{array}{l}\mathrm{CH}_{4} \\
\mathrm{~h}^{-1}\end{array}$ & $\begin{array}{l}\mathrm{CO}_{2} \\
\mathrm{mg} \mathrm{m}^{-2} \mathrm{~h}^{-1}\end{array}$ & \\
\hline Colombia & upper slope & & 700 & 853 & 24 & & & & 137.50 & Cavelier and Penuela, (1990) \\
\hline Australia, Kauri Creek & slope: $12-14^{\circ}$ & Ustochrept & $700-900$ & 1594 & 21 & 49.77 & & -36.0 & 131.55 & $\begin{array}{l}\text { Kiese et al. (2008), Kiese and } \\
\text { Butterbach -Bahl. (2002) }\end{array}$ \\
\hline Hawai’i, Mauna Loa & lower slope & $\begin{array}{l}\text { Acrudoxic } \\
\text { Hydrudand }\end{array}$ & 760 & 6000 & 19 & & & & 101.60 & Raich, (1998) \\
\hline China & slope: $5-35^{\circ}$ & $\begin{array}{l}\text { lateritic red/ } \\
\text { yellow soils }\end{array}$ & 770 & 1493 & 22 & 6.0 & & -29.5 & 68.8 & Werner et al. (2006) \\
\hline Congo & hillside & & 900 & 1500 & & & & -46.8 & & Delmas et al. (1992) \\
\hline Ecuador, Bombuscaro & lower slope & Dystropept & $990-1200$ & 2000 & 20 & 1.90 & 0.75 & -62.56 & 117.12 & This study \\
\hline Ecuador, Bombuscaro & midslope & Dystropept & $990-1200$ & 2000 & 20 & 3.53 & 1.11 & -61.15 & 117.01 & This study \\
\hline Ecuador, Bombuscaro & ridge & $\begin{array}{l}\text { Humitropept/ } \\
\text { Dystropept }\end{array}$ & $990-1200$ & 2000 & 20 & 4.14 & 0.72 & -67.29 & 111.87 & This study \\
\hline Puerto Rico & $\begin{array}{l}\text { ridges/upper } \\
\text { slope }\end{array}$ & Ultisols & 1000 & 5000 & 21 & & & & 96.77 & McGroddy and Silver, (2000) \\
\hline Australia, Maasy Creek & slope: $18-20^{\circ}$ & Kandihumult & 1020 & 2350 & 20 & 42.81 & & & 161.4 & Breuer et al. (2000) \\
\hline Hawai'i, Puu Makaala & & Hydrandept & 1112 & 3800 & 17 & 2.50 & & & & Riley and Vitousek (1995) \\
\hline Hawai'i, Kohala & & Placandept & 1122 & 2540 & 16 & 4.50 & & & & Riley and Vitousek (1995) \\
\hline Hawai'i, Kauai & & & 1134 & 2410 & 16 & 3.10 & & & & Riley and Vitousek (1995) \\
\hline Hawai'i, Kilauea & & Dystrandept & 1176 & 2410 & 16 & 0.13 & & & & Riley and Vitousek (1995) \\
\hline Indonesia, Sulawesi & lower slope & $\begin{array}{l}\text { Entisols and } \\
\text { Fluvisols }\end{array}$ & 1190 & 1590 & 23 & 12.67 & 5.48 & -27.97 & & Purbopuspito et al. (2006) \\
\hline Panama, Fortuna & slope $<15 \%$ & Andosols & 1200 & 5532 & 20 & 14.84 & 1.14 & & 107.30 & Köhler et al. (2009b, 2009a) \\
\hline Hawai'i, Kilauea & & Volcanic ash & 1200 & 2200 & 16 & 0.60 & & & & Matson and Vitousek (1987) \\
\hline Hawai'i, Kilauea & & Volcanic ash & 1200 & 3500 & 16 & 1.85 & & & & Matson and Vitousek (1987) \\
\hline Hawai'i, Mauna Loa & & Volcanic ash & 1200 & 4500 & 16 & 1.80 & & & & Matson and Vitousek (1987) \\
\hline Hawai'i, Molokai & & Placandept & 1267 & 2500 & 16 & 1.63 & & & & Riley and Vitousek (1995) \\
\hline Hawai'i, Maui & slope $<5 \%$ & Andisols & 1300 & 4050 & 16 & 1.82 & 0.00 & & & Holtgrieve et al. (2006) \\
\hline Hawai'i, Maui & slope $<5 \%$ & Andisols & 1320 & 3350 & 16 & 8.41 & 2.00 & & & Holtgrieve et al. (2006) \\
\hline
\end{tabular}




\begin{tabular}{|c|c|c|c|c|c|c|c|c|c|c|}
\hline Hawai'i, Maui & slope $<5 \%$ & Inceptisols & 1370 & 2200 & 16 & 11.14 & 87.00 & & & Holtgrieve et al. (2006) \\
\hline Indonesia, Sumatra & slope: $17-31^{\circ}$ & Andisols & 1540 & $\sim 2500$ & 25 & 3.83 & & -36.30 & & Ishizuka et al. (2005) \\
\hline Hawai'i, Mauna Loa & & Histosols & 1600 & 2600 & 13 & & & & 74.20 & Raich, (1998) \\
\hline Ecuador, ECSF & lower slope & $\begin{array}{l}\text { Dystropept/ } \\
\text { Eutropept }\end{array}$ & $1800-2100$ & 2200 & 15 & 14.54 & 1.11 & -25.77 & 100.46 & This study \\
\hline Ecuador, ECSF & midslope & Dystropept & $1800-2100$ & 2200 & 15 & 3.68 & 1.13 & -49.54 & 86.76 & This study \\
\hline Ecuador, Cajanuma & lower slope & $\begin{array}{l}\text { Typic } \\
\text { Albaquults }\end{array}$ & $2800-3000$ & 5400 & 10 & 1.63 & 0.19 & -6.89 & 73.06 & This study \\
\hline Ecuador, Cajanuma & midslope & $\begin{array}{l}\text { Aquic } \\
\text { Dystropepts }\end{array}$ & $2800-3000$ & 5400 & 10 & 1.34 & 0.06 & -17.99 & 65.07 & This study \\
\hline Ecuador, Cajanuma & ridge & $\begin{array}{l}\text { Histic } \\
\text { Albaquults }\end{array}$ & $2800-3000$ & 5400 & 10 & -0.53 & -0.02 & -11.05 & 42.24 & This study \\
\hline
\end{tabular}

*This listing is not meant to be complete, but to give an overview of the range of published data 


\section{Nutrient availability affected soil trace gas fluxes}

Soil N-oxide, $\mathrm{CH}_{4}$ and $\mathrm{CO}_{2}$ fluxes were positively correlated to indices of $\mathrm{N}$ availability in soil and litterfall along the elevation and topographic gradients. Soil respiration was also positively correlated to $\mathrm{C}: \mathrm{K}$ and $\mathrm{C}: \mathrm{P}$ ratios in litterfall, and negatively correlated to soil moisture content and organic layer thickness. The positive relationship between $\mathrm{N}$-oxide emissions and $\mathrm{N}$ availability (Chapter 2) confirms hypothesis 1, and corroborates the conceptual 'hole-in-thepipe'- model, which states that higher soil $\mathrm{N}$ availability will lead to higher $\mathrm{N}$ losses via N-oxide emissions (Davidson et al. 2000; Firestone \& Davidson 1989). Field-measured atmospheric $\mathrm{CH}_{4}$ uptake was positively correlated to $\mathrm{CO}_{2}$ emissions, $\mathrm{P}$ concentration in the mineral soil and mineral $\mathrm{N}$ contents in the soil. This surprising positive correlation between field-measured atmospheric $\mathrm{CH}_{4}$ uptake and $\mathrm{N}$ availability falsifies hypothesis 4 . Instead of an ammonia inhibition effect, I found evidence, that more favorable conditions for microbial activity (e.g. higher litter quality) enhanced soil respiration, mineralization and nitrification rates, as well as atmospheric $\mathrm{CH}_{4}$ uptake by soils. This conclusion is supported by the positive correlation between soil respiration and atmospheric $\mathrm{CH}_{4}$ uptake. The relationships of litter quality and soil moisture with soil respiration (Chapter 4), as well as the first results of a decomposition experiment in the study area suggest that microbial activity and decomposition was mainly limited by litter quality in these TMFs (Homeier \& Werner, unpublished data). In summary, I found that trace gas fluxes were influenced by nutrient availability along the environmental gradients in the investigated TMF. This finding was consistent for $\mathrm{N}$-oxides, $\mathrm{CO}_{2}$, and $\mathrm{CH}_{4}$ throughout the study period; although not all indices of nutrient availability correlated with all trace gas fluxes.

Aboveground tree productivity was closely related to $N, P$ and $K$ availability, whereas belowground carbon allocation did not show any interdependencies

Confirming hypothesis 2, indices of aboveground forest productivity (litter production and tree basal area increment) were positively correlated with indices of nitrogen availability $\left(\delta{ }^{15} \mathrm{~N}\right.$ signature and $\mathrm{C}: \mathrm{N}$ ratios in litterfall), irrespective of elevation and topographic position. Litter production was also positively correlated with available $\mathrm{P}$ in the organic layer. Available $\mathrm{K}$ described a saturation function with aboveground litter production, which indicates that at some 
sites $\mathrm{K}$ was not a limiting factor. Concentrations of $\mathrm{P}$ and $\mathrm{K}$ in litterfall correlated with the availability of the respective nutrient in the organic layer. These results, presented in Chapter 2 and Chapter 4, suggest that forest productivity was not limited by one nutrient alone, but both $\mathrm{N}$ and $\mathrm{P}$ could be limiting at all study sites and $\mathrm{K}$ was also potentially limiting at most sites. This confirms findings from other studies in TMFs, that tree growth in montane forests is mainly $\mathrm{N}$ and P limited (Cavelier et al. 2000; Grubb 1977; Homeier et al. 2010; Tanner et al. 1992). Nitrogen addition experiments carried out in tropical montane forests, including forests close to our study sites, also showed increases in aboveground forest productivity following fertilization indicating nutrient limitation (Adamek et al, 2009, Homeier et al., unpublished data). The good correlations found in the study are also due to the wide range of nutrient availabilities found along the environmental gradients.

Contradicting hypothesis 7, TBCA decreased with increasing elevation and from lower slopes to the ridges. The lack of correlations with soil N, P and K availability (Chapter 4) suggests that TBCA was not affected by the investigated nutrients. Instead, TBCA was inversely correlated with organic layer thickness and soil moisture content. These results seem to disagree with allocation theory which states that plants countervail growth limitations by investing more $\mathrm{C}$ into the respective plant structures able to reduce limitation (Raich 1998). Hence, relatively more $\mathrm{C}$ should be invested below ground (i.e. into roots) than into leaves, if nutrients limited plant growth stronger than light and $\mathrm{CO}_{2}$, (Raich 1998). The increase in root/shoot ratio and root biomass found with elevation in our study area suggests that root productivity and TBCA should also increase (Leuschner et al. 2007; Röderstein et al. 2005). However, considering our findings of a decrease in absolute TBCA with increasing altitude, this assumption seems not to hold true for the investigated forests and the larger root biomass may better be explained by increasing root longevity. Together with low decomposition rates in the organic layers, this may lead to higher and longer-term storage of organic $\mathrm{C}$ in the soil.

In summary the results presented in Chapter 2 and Chapter 4 show, that aboveground litter production and TBCA are not directly linked through nutrient availability and that the decrease in aboveground productivity was probably not balanced by an increase in TBCA. 
Tree basal area increment as promising proxy to estimate soil $N$-oxide fluxes in $N$ limited ecosystems

As indicated by the positive correlation, tree productivity and soil N-oxide emissions were linked through $\mathrm{N}$ availability (Chapter 2). This result confirms hypothesis 3 and suggests that forest productivity may be a suitable predictor of soil $\mathrm{N}$-oxide emissions in $\mathrm{N}$ limited tropical montane forests. Information on ecosystem productivity, especially on litter production, is available for a wide range of forest ecosystems. However, since litterfall is quite variable and some studies reported extremely high litter production rates with high standard errors (Purbopuspito et al. 2006) it may not be the predicting parameter of choice. Instead, tree basal area increment, which showed closer correlations with soil N-oxide emissions than litter production in the studied site, may be a better long-term measure of forest productivity. It is important to note that predictive relationships can only be expected if $\mathrm{N}$ limits forest productivity because, in $\mathrm{N}$-rich ecosystems, additional $\mathrm{N}$ will further enhance $\mathrm{N}$-oxide emissions but not affect forest productivity.

\section{Soil organic layers showed potential to consume atmospheric methane}

Methane uptake rates of the incubated organic layer samples from the $1000 \mathrm{~m}$ site confirmed the widely accepted notion that organic layers consume only little, if any, atmospheric $\mathrm{CH}_{4}$ (Adamsen \& King 1993; Brumme \& Borken 1999; Butterbach-Bahl \& Papen 2002b; Saari et al. 1998). In contrast, organic layer samples from the $2000 \mathrm{~m}$ and $3000 \mathrm{~m}$ site revealed substantial potential for oxidizing $\mathrm{CH}_{4}$ at atmospheric concentrations. Largest uptake rates were found in the lowermost organic layers just above the mineral soil suggesting a high abundance of methanotrophic bacteria in these samples (Chapter 3). This deep location of the maximum $\mathrm{CH}_{4}$ uptake capacity is remarkable. It may result form ammonia inhibition in the upper organic layers or from the sensitivity of microorganisms to temperature and moisture changes, which are larger in the upper organic layer (Butterbach-Bahl \& Papen 2002b; Schnell \& King 1994). Potential uptake of atmospheric $\mathrm{CH}_{4}$ in the underlying mineral soil was lower than in the lower organic layers, possibly because of the better aeration of the latter. Contradicting hypothesis 6, soil organic layers may strongly influence the $\mathrm{CH}_{4}$ budget of tropical montane rain forests. 


\subsection{Implications for ecosystem response to environmental change}

The results obtained in this study show that nutrient and C cycling of TMFs is not spatially homogeneous throughout the ecosystem. This implies that environmental changes such as elevated $\mathrm{N}$ input or climate change have different impact on TMFs not only at different elevations, but also at distinct topographic positions. Forests at lower slope positions reveal more open $\mathrm{N}$ cycles and might therefore respond more sensitively to elevated $\mathrm{N}$ input, with enhanced gaseous and leaching losses of $\mathrm{N}$. In contrast, the tight $\mathrm{N}$ cycling and high net microbial $\mathrm{N}$ immobilization at ridge positions and at higher elevations might not be overcome for some time. Elevated $\mathrm{N}$ input may also lead to higher $\mathrm{CH}_{4}$ uptake rates on the ridges, as this process was shown to be $\mathrm{N}$ limited, whereas ammonia inhibition of $\mathrm{CH}_{4}$ oxidation might gain importance at the lower slopes. Improved litter quality and enhanced mineralization and nitrification rates following elevated $\mathrm{N}$ input might lead to a decrease of organic layer thickness and to changes in carbon sequestration. Enhanced mineralization rates and nutrient availability following $\mathrm{N}$ fertilization may increase gross primary productivity and change carbon allocation pattern along the elevational and topographic gradients. They might result in a shift from belowground to aboveground $\mathrm{C}$ allocation and to primarily in increasing aboveground $\mathrm{C}$ allocation at less nutrient-limited sites, whereas higher gross primary productivity might lead to an overall increment of belowground and aboveground productivity at stronger nutrient limited sites.

Predicted increases in air temperature and atmospheric $\mathrm{CO}_{2}$ concentrations are likely to affect biochemical cycling and ecosystem functioning, although possibly less pronounced in the tropics compared to other biomes. Especially decomposition rates in tropical forest soils have been shown to be sensitive to temperature changes. One possible consequence of higher decomposition rates, resulting from temperature increases are higher soil respiration rates and a decline in soil carbon storage. To which degree increasing net primary productivity and increased plant $\mathrm{C}$ fixation balance the additional $\mathrm{C}$ losses is regulated by the availability of potentially limiting nutrients. Another consequence of higher decomposition rates is the increase in nutrient availability especially of $\mathrm{N}$, which is covalently bonded with $\mathrm{C}$ in the organic matter. Enhanced $\mathrm{N}$ availability influences forest growth, carbon storage, and also trace gas fluxes. One possible scenario following elevated atmospheric $\mathrm{CO}_{2}$ concentrations and higher temperatures might include higher net primary productivity at less nutrient limited sites, which, on longer time 
scales, could lead to nutrient limitations and the change in carbon allocation from aboveground to belowground plant structures. Enhanced decomposition of the organic matter accumulated at the ridge positions and higher altitudes lead to higher nutrient availability, to a decrease in soil carbon storage and possibly to higher leaching and gaseous nutrient losses. However, predicting the consequences of temperature increase and higher atmospheric $\mathrm{CO}_{2}$ concentrations on forest productivity and carbon allocation is difficult due to complex feedback processes between soil organic matter, soil microorganisms and plants and due to the high tree species diversity of the study area. Different tree species have been shown to react differently on nutrient additions in a close-by nutrient manipulation experiment. While some species showed increased growth and litter productivity following fertilization on a nutrient limited site, other tree species did not. Less speculative is the implication that plant species distribution may change due to higher nutrient availability and higher temperatures. Lowland species may infiltrate to higher elevations and fast growing, nutrient demanding species might replace slow growing, well adapted plant species from the ridge forests. Such shifts in plant species composition could lead to the disappearance of very specialized species and to a decrease in plant diversity of TMFs.

\subsection{Suggestions for future research}

The results obtained in this study contribute to the understanding of nutrient and carbon cycling of tropical montane forests and provide valuable information for the prediction and modeling of their soil trace gas fluxes. For future research I suggest to focus on the investigation of processes involved in soil $\mathrm{N}$ and $\mathrm{C}$ turnover and allocation, which will allow for an improved estimation of environmental change impacts on TMF ecosystems. The following important, open and new questions arising from this study should be addressed.

What is the total amount of $N$ turnover and $N$ retention rates?

While net mineralization and nitrification rates, are a good index for plant available $\mathrm{N}$, they do not reveal the total amount of $\mathrm{N}$ turnover and $\mathrm{N}$ retention rates in the soil. Central processes of the $\mathrm{N}$ cycle, such as gross mineralization, immobilization and nitrification, have been successfully investigated by means of the ${ }^{15} \mathrm{~N}$ pool dilution technique (Corre et al. 2003; 
Davidson et al. 1991; Sotta et al. 2008). Additionally, ${ }^{15} \mathrm{~N}$ tracing using small amounts of highly enriched ${ }^{15} \mathrm{NH}_{4}^{+}$give insight into the pathway of mineralized nitrogen, the immobilization and leaching as well as gaseous losses. These methods might also provide information on the specific role of the organic layer for $\mathrm{N}$ transformation processes and provide a more appropriate measure to characterize possible inhibition of $\mathrm{CH}_{4}$ uptake in the upper organic layers than the traditionally used soil extractable ammonium.

Where is main soil $N$ turnover concentrated and does this location change with topographic position along the elevation gradient?

Natural abundances of ${ }^{15} \mathrm{~N}$ of forest ecosystems can also be consulted for further investigation of the soil $\mathrm{N}$ cycle (Poertl et al. 2007). Several microbial processes in the soil discriminate against the isotopically heavy ${ }^{15} \mathrm{~N}$ isotope (Mariotti et al. 1981; Nadelhoffer \& Fry 1988). Hence, faster mineralization rates lead to relatively higher ${ }^{15} \mathrm{~N}$ enrichment of the residual material, reflecting cumulative $\mathrm{N}$ losses (Hogberg and Johannisson 1993) and indicating openness of the ecosystem $\mathrm{N}$ cycle (Vitousek et al. 1989). In forest soil profiles, $\delta^{15} \mathrm{~N}$ signatures have been shown to shift to more enriched values with depth, indicating faster mineralization of isotopically depleted organic $\mathrm{N}$ in the upper soil layers and an enrichment of residual soil organic matter in ${ }^{15} \mathrm{~N}$ at deeper depths (Nadelhoffer \& Fry 1988; Vervaet et al. 2002). I expect less negative enrichment factors for sites with slower $\mathrm{N}$ cycling. First calculations with data from my study site suggest that $\mathrm{N}$ cycling may be decoupled from the mineral soil. Natural abundance of ${ }^{15} \mathrm{~N}$ data and enrichment factors of our study site could be combined with data from the nearby fertilization experiment to explore if nutrient application stimulates soil $\mathrm{N}$ cycling and possibly reduces the decoupling of mineral soil and organic layer.

How is carbon partitioned between plant organs and how do these pattern change with elevation and along topographic gradients?

Isotopic tracer techniques may also be used for a more direct estimation of belowground $\mathrm{C}$ allocation. Plain et al. (2009) and Hogberg et al. (2010) presented approaches to pulse-label fullgrown single trees or even forest patches in situ over a time period of a few hours. Trees exposed 
to a ${ }^{13} \mathrm{C}-\mathrm{CO}_{2}$ labeled atmosphere take up the labeled ${ }^{13} \mathrm{C}$ and translocate it into plant tissues including roots, from where it becomes available to soil microorganisms. Measuring ${ }^{13} \mathrm{C}$ in leaves, roots, soil microorganisms and soil $\mathrm{CO}_{2}$ efflux may help to understand $\mathrm{C}$ partitioning. This approach allows for tracing $\mathrm{C}$ fluxes to different groups of soil organisms and determination of residence times in different tree and soil compartments. Consequently it may facilitate estimations on the contribution of TMF in terms of belowground $\mathrm{C}$ sequestration. Although this approach is methodologically challenging it might improve estimates received from indirect methods such as root washing, determination of root biomass and root necromass, by including root exudation and mycorrhizal fungi. Other tracing methods, such as the injection of ${ }^{13} \mathrm{C}$ labeled glucose into plant tissues, might be easier to handle and lead to similar results, but they imply an additional carbon input to plant tissue.

Which mechanisms are responsible for the deep location of the maximum $\mathrm{CH}_{4}$ oxidation potential in soil organic layers at high elevations?

The deep location of the maximum $\mathrm{CH}_{4}$ oxidation potential in soil organic layers may be a result of one or both of the following mechanisms. First, in the upper organic layer the potential to oxidize diffusing atmospheric $\mathrm{CH}_{4}$ is reduced due to processes, such as $\mathrm{NH}_{4}^{+}$inhibition, or adverse soil conditions impeding microbial growth. Second, water logging of the underlying mineral soil after heavy rainfall creates anaerobic conditions, and temporally turns the mineral soil into a $\mathrm{CH}_{4}$ source. Evidence for possible $\mathrm{NH}_{4}{ }^{+}$inhibition may be provided by the determination of gross mineralization and nitrification rates, as well as the measurement of $\mathrm{NH}_{4}{ }^{+}$ concentrations in the upper organic layer. Frequent measurements of soil-air $\mathrm{CH}_{4}$ concentrations could be conducted to examine a possible reverse of soil functioning as $\mathrm{CH}_{4}$ sink into a source after wet periods. Additionally, chloroform fumigation extraction of soil samples, the identification of microbial bacteria, analysis of phospholipid fatty acids composition and DNA extractions from cell cultures may provide information on the abundance and type of methanotrophic bacteria in different soil depths. This data may contribute to the identification of a prevailing form of methanotrophic oxidation (low or high affinity oxidation) in the respective soil depths. 
In addition to process-based investigations fertilization experiments including $\mathrm{N}, \mathrm{P}$ and $\mathrm{K}$ additions could be realized at the different topographic positions along the elevation gradient. The results of such experiments allow for a more direct investigation of the respective nutrient limitations on plant growth, plant regeneration dynamics and bacterial activity. Furthermore, nitrogen fertilization experiments are valuable to examine possible impacts of elevated $\mathrm{N}$-inputs on TMF ecosystem functioning, including trace gas fluxes, carbon sequestration, nutrient cycling and nutrient losses, forest productivity, regeneration dynamics and plant species composition. 


\subsection{References}

Adamek, M., Corre, M. D., and Hölscher, D. (2009) Early effect of elevated nitrogen input on above-ground net primary production of a lower montane rain forest, Panama, Journal of Tropical Ecology, 25, 637-647, 10.1017/s0266467409990253.

Adamsen, A. P. S., and King, G. M. (1993) Methane consumption in temperate and sub-arctic forest soils- rates, vertical zonation, and responses to water and nitrogen, Applied and Environmental Microbiology, 59, 485-490.

Breuer, L., Papen, H., and Butterbach-Bahl, K. (2000) $\mathrm{N}_{2} \mathrm{O}$ emission from tropical forest soils of Australia, Journal of Geophysical Research-Atmospheres, 105, 26353-26367.

Brumme, R., and Borken, W. (1999) Site variation in methane oxidation as affected by atmospheric deposition and type of temperate forest ecosystem, Global Biogeochemical Cycle, 13, 493-501.

Butterbach-Bahl, K., and Papen, H. (2002) Four years continuous record of CH4-exchange between the atmosphere and untreated and limed soil of a N-saturated spruce and beech forest ecosystem in Germany, Plant and Soil, 240, 77-90,

Cavelier, J., and Penuela, M. C. (1990) Soil respiration in the cloud forest and dry deciduous forest of Serrania de Macuira, Colombia Biotropica, 22, 346-352.

Cavelier, J., Tanner, E., and Santamaria, J. (2000) Effect of water, temperature and fertilizers on soil nitrogen net transformations and tree growth in an elfin cloud forest of Colombia, Journal of Tropical Ecology, 16, 83-99.

Corre, M. D., Beese, F. O., and Brumme, R. (2003) Soil nitrogen cycle in high nitrogen deposition forest: Changes under nitrogen saturation and liming, Ecological Applications, 13, 287-298.

Davidson, E. A., Hart, S. C., Shanks, C. A., and Firestone, M. K. (1991) Measuring gross nitrogen mineralization, immobilization and nitrification by N15 isotopic pool dilution in intact soil cores, Journal of Soil Science, 42, 335-349.

Davidson, E. A., Keller, M., Erickson, H. E., Verchot, L. V., and Veldkamp, E. (2000): Testing a conceptual model of soil emissions of nitrous and nitric oxides, Bioscience, 50, 667-680.

Delmas, R. A., Servant, J., Tathy, J. P., Cros, B., and Labat, M. (1992) Sources and sinks of methane and carbon-dioxide exchanges in mountain forest in Equatorial Africa, Journal of Geophysical Research-Atmospheres, 97, 6169-6179.

Dörr, H., Katruff, L. and Levin, I. (1993) Soil texture parameterization of the methane uptake in aerated soils, Chemosphere, 26, (1-4), 697-713.

Erickson, H., Keller, M. and A., D. E. (2001) Nitrogen oxide fluxes and nitrogen cycling during postagricultural succession and forest fertilization in the humid tropics, Ecosystems, 4, 6784.

Firestone, M. K., and Davidson, E. A. (1989) Microbiological basis of $\mathrm{NO}$ and $\mathrm{N}_{2} \mathrm{O}$ production and consumption in soil. In: Exchange of Trace Gases between Terrestrial Ecosystems and the Atmosphere, Andreae, M. O., and Schimel, D. S. (eds.), John Wiley\&Sons, New York, 7-21.

Grubb, P. J. (1977) Control of forest growth and distribution on wet tropical mountains: with special reference to mineral nutrition, Annual Review of Ecology and Systematics, 8, 83107. 
Hertel, D., Leuschner, C. and Hölscher, D. (2003): Size and Structure of Fine Root Systems in Old-growth and Secondary Tropical Montane Forests (Costa Rica), Biotropica, 35, (2), 143-153.

Hogberg, M. N., Briones, M. J. I., Keel, S. G., Metcalfe, D. B., Campbell, C., Midwood, A. J., Thornton, B., Hurry, V., Linder, S., Nasholm, T., and Hogberg, P. (2010) Quantification of effects of season and nitrogen supply on tree below-ground carbon transfer to ectomycorrhizal fungi and other soil organisms in a boreal pine forest, New Phytologist, 187, 485-493, 10.1111/j.1469-8137.2010.03274.x.

Hogberg, P., and Johannisson, C. (1993) N-15 abundance of forests is correlated with losses of nitrogen, Plant and Soil, 157, 147-150.

Holtgrieve, G. W., Jewett, P. K., and Matson, P. A. (2006) Variations in soil N cycling and trace gas emissions in wet tropical forests, Oecologia, 146, 584-594, 10.1007/s00442-005-02221 .

Homeier, J., Breckle, S.-W., Günter, S., Rollenbeck, R. T., and Leuschner, C. (2010) Tree diversity, forest structure and productivity along altitudinal and topographical gradients in a species-rich Ecuadorian montane rain forest, Biotropica, 42, 140-148.

Ishizuka, S., Iswandi, A., Nakajima, Y., Yonemura, S., Sudo, S., Tsuruta, H., and Murdiyarso, D. (2005) The variation of greenhouse gas emissions from soils of various land-use/cover types in Jambi province, Indonesia, Nutrient Cycling in Agroecosystems, 71, 17-32, 10.1007/s10705-004-0382-0.

Kiese, R., Wochele, S., and Butterbach-Bahl, K. (2008) Site specific and regional estimates of methane uptake by tropical rainforest soils in north eastern Australia, Plant and Soil, 309, 211-226, 10.1007/s11104-008-9545-0.

Kiese, R., and Butterbach-Bahl, K. (2002) N2O and CO2 emissions from three different tropical forest sites in the wet tropics of Queensland, Australia, Soil Biology and Biochemistry, 34, 975-987.

Köhler, B., Corre, M. D., Veldkamp, E., and Sueta, J. P. (2009a) Chronic nitrogen addition causes a reduction in soil carbon dioxide efflux during the high stem-growth period in a tropical montane forest but no response from a tropical lowland forest in decadal scale, Biogeosciences Discussions, 6, 1-28.

Köhler, B., Corre, M. D., Veldkamp, E., Wullaert, H., and Wright, J. S. (2009b) Immediate and long-term nitrogen oxide emissions from tropical forest soils exposed to elevated nitrogen imput, Global Change Biology 15, 8. 2049-2066.

Leuschner, C., Moser, G., Bertsch, C., Röderstein, M., and Hertel, D. (2007) Large altitudinal increase in tree root/shoot ratio in tropical mountain forests of Ecuador, Basic and Applied Ecology 8, 219-230.

Leuschner, C. and Moser, G. (2008) Carbon allocation and productivity in tropical montane forests. In: The tropical mountain forest - Pattern and processes in a biodiversity hotspot, Gradstein, S. R., Jürgen Homeier and Dirk Gansert (eds.),Universitätsverlag Göttingen, Göttingen.

Mariotti, A., Germon, J. C., Hubert, P., Kaiser, P., Letolle, R., Tardieux, A., and Tardieux, P. (1981) Experimental determination of nitrogen kinetic isotope fractionation: Some principles; Illustration for the denitrification and nitrification processes, Plant and Soil, 62, 413-430.

Matson, P. A., and Vitousek, P. M. (1987) Cross-system comparisons of soil nitrogen transformations and nitrous oxide flux in tropical forest ecosystems, Global Biochemical Cycles, 1, 163-170. 
McGroddy, M., and Silver, W. L. (2000) Variations in Belowground Carbon Storage and Soil CO2 Flux Rates along a Wet Tropical Climate Gradient1, BIOTROPICA, 32, 614-624.

Nadelhoffer, K. J., and Fry, B. (1988) Controls on natural nitrogen-15 and carbon-13 abundances in forest soil organic matter, Soil Science Society of America Journal, 52, 1633-1640.

Plain, C., Gerant, D., Maillard, P., Dannoura, M., Dong, Y. W., Zeller, B., Priault, P., Parent, F., and Epron, D. (2009) Tracing of recently assimilated carbon in respiration at high temporal resolution in the field with a tuneable diode laser absorption spectrometer after in situ (CO2)-C-13 pulse labeling of 20-year-old beech trees, Tree Physiology, 29, 1433-1445, 10.1093/treephys/tpp072.

Poertl, K., S., Z.-B., Wanek, W., Ambus, P., and Berger, T. W. (2007) Natural 15N abundance of soil N pools and N2O reflect the nitrogen dynamics of forest soils, Plant Soil 295, 79-94,

Purbopuspito, J., Veldkamp, E., Brumme, R., and Murdiyarso, D. (2006) Trace gas fluxes and nitrogen cycling along an elevation sequence of tropical montane forests in Central Sulawesi, Indonesia, Global Biogeochemical Cycle, 20, 11, Gb3010, $10.1029 / 2005 \mathrm{gb} 002516$.

Raich, J. W. (1998): Aboveground productivity and soil respiration in three Hawaiian rain forests, Forest Ecology and Management, 107, 309-318.

Riley, R. H., and Vitousek, P. M. (1995) Nutrient dynamics and nitrogen trace gas flux during ecosystem developement in montane rain forest, Ecology, 76, 292-304.

Röderstein, M., Hertel, D., and Leuschner, C. (2005) Above- and below-ground litter production in three tropical montane forests in southern Ecuador, Journal of Tropical Ecology, 21, 483-492.

Saari, A., Heiskanen, J., and Martikainen, P. J. (1998) Effect of the organic horizon on methane oxidation and uptake in soil of a boreal Scots pine forest, Fems Microbiology Ecology, 26, 245-255.

Schnell, S. and King, G. M. (1994) Mechanistic analysis of ammonium inhibition of atmospheric methane consumption in forest soils, Applied and Environmental Microbiology, 60, (10), 3514-3521.

Sotta, E. D., Corre, M. D., and Veldkamp, E. (2008) Differing N status and N retention processes of soils under old-growth lowland forest in Eastern Amazonia, Caxiuana, Brazil, Soil Biology \& Biochemistry, 40, 740-775.

Tanner, E. V. J., Kapos, V., and Franco, W. (1992) Nitrogen and phosphorus fertilization effects on Venezuelan montane forest trunk growth and litterfall, Ecology, 73, 78-86.

Veldkamp, E., Purbopuspito, J., Corre, M. D., Brumme, R., and Murdiyarso, D. (2008) Land use change effects on trace gas fluxes in the forest margins of Central Sulawesi, Indonesia, Journal of Geophysical Research-Biogeosciences., 113, 11, G02003 10.1029/2007jg000522.

Vervaet, H., Boeckx, P., Unamuno, V., Van Cleemput, O., and Hofman, G. (2002) Can delta N15 profiles in forest soils predict NO3- loss and net N mineralization rates?, Biology and Fertility of Soils, 36, 143-150, 10.1007/s00374-002-0522-0.

Vitousek, P. M., Shearer, G., and Kohl, D. H. (1989) Foliar N-15 natural abundance in Hawaiian rainforest-pattern and possible mechanisms, Oecologia, 78, 383-388.

Werner, C., Zheng, X. H., Tang, J. W., Xie, B. H., Liu, C. Y., Kiese, R., and Butterbach-Bahl, K. (2006) N2O, CH4 and CO2 emissions from seasonal tropical rainforests and a rubber plantation in Southwest China, Plant and Soil, 289, 335-353, 10.1007/s11104-006-9143-y. 


\section{ACKNOWLEDGEMENTS}

I wish to thank Prof. Edzo Veldkamp and Prof. Heiner Flessa for the supervision through this $\mathrm{PhD}$ thesis and for giving me the chance to appreciate this great experience.

My dear colleague Guntars Martinson, for his enthusiasm and motivating attitude and for his help especially in the first time of the PhD work.

Mis assistentes, para ser unos compañeros del trabajo muy confiables y comprometidos y por ser unos buenos amigos, que me hicieron lindo el tiempo en Ecuador: Patricio Salas, Angel Macas, Marco Silva, Richard and Vicente Sanmaniego y Fabian Cuenca

Dem Labor-Team des Büsgen-Institutes der Universität Göttingen für die engagierte und sorgfältige Bearbeitung der Projektproben.

My colleagues for all kinds of much appreciated support and friendship during my work in Ecuador and Göttingen. Especially: Ina Hoeft, Jürgen Homeier, Birgit Köhler, Florian Werner Nadine Eickenscheidt, Oliver van Straaten, Christoph Scherber and Wolde Mecuria.

Mis amigos de la estaciòn, para la ajuda y el tiempo inolividable en Ecuador. Especialmente a Baltazar Calvas para toda la ayuda, tambien con la parte del Resumen de esta thesis.

The German research foundation (DFG) for the financial support of the research unit 816: 'Biodiversity and Sustainable Management of a Megadiverse Mountain Ecosystem in South Ecuador', including this study.

Meiner Familie (den Clans Wolf, Rutkowski und Pfost), die mir immer den Rücken frei hält. Danke. 


\section{DECLARATION OF ORIGINALITY AND CERTIFICATE OF AUTHORSHIP}

I, Katrin Wolf, hereby declare that I am the soil author of this dissertation entitled "Trace gas fluxes from tropical montane rain forest soils". It has not previously been submitted in any form for another degree at any university or other institute of tertiary education. Information derived from the published and unpublished work of other authors has been appropriately acknowledged in the text and a list of references is given in the bibliography. I certify that the manuscripts presented in the chapters 2,3 and 4 have been written by me as first author.

Goettingen, October 12, 2011

(Katrin Wolf) 


\section{CURRICULUM VitAE}

PERSonAl InFORMATION

$\begin{array}{ll}\text { Name } & \text { Katrin Wolf } \\ \text { Date of birth } & 22.08 .1980 \\ \text { Place of birth } & \text { Dachau }\end{array}$

EDUCATION AND RESEARCH EXPERIENCE

05/2007-05/2010 Research Assistant at the Büsgen Institute for Ecopedology of the Tropics and Subtropics, Göttingen, Germany

$\mathrm{PhD} /$ Doctorate

Since $05 / 2007$

Georg-August University Göttingen

Center of Biodiversity Research and Ecology

Academic studies

2000- 2006

Ludwig-Maximilians-University, Munich, Dep. of Geography

Subject Physical Geography (Diploma)

Subsidiary subjects

1) Inorganic Chemistry

2) Bioclimatology and Emission research (Technical University, Munich)

Additional subject Soil Science (Technical University, Munich)

Grammar School

$09 / 1991-07 / 2000$

Josef-Effner-Gymnasium, Dachau, Bayern, Germany

\section{Publications}

Martinson, G.; Werner, F.A.; Scherber, C.; Conrad, R.; Corre, M.; Flessa, H.; Wolf, K.; Klose, M.; Gradstein, S.R. \& Veldkamp, E. (2010): Methane emissions from tank bromeliads in neotropical forests. Nature Geoscience AOP, online first, DOI: http://dx.doi.org/DOI: 10.1038/NGEO980. 